\author{
Universidad de León \\ Facultad de Veterinaria
}

Dpto. Higiene y Tecnología de los Alimentos

MEMORIA DE TESIS DOCTORAL

"Incidencia, Comportamiento y

Control de Tipos Patógenos de

Escherichia coli (STEC y EPEC) en

Leche y Queso de Oveja"

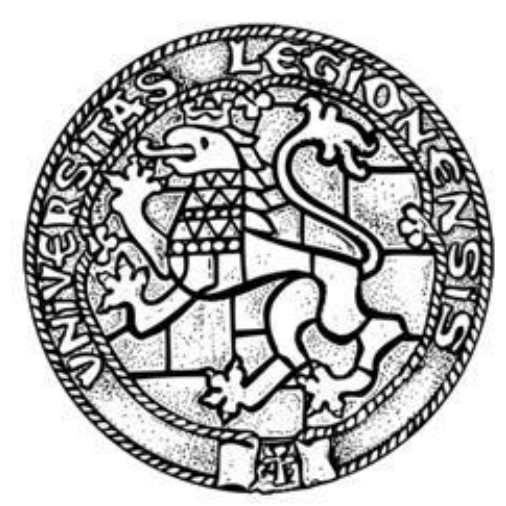

Verónica Otero Álvarez

León, 2014 



\section{INFORME DEL DIRECTOR DE LA TESIS}

La Dra. Dña. María Luisa García López y el Dr. D. José María Rodríguez Calleja como Directores de la Tesis Doctoral titulada "Incidencia, Comportamiento y Control de Tipos Patógenos de Escherichia coli (STEC y EPEC) en Leche y Queso de Oveja" realizada por Dña. Verónica Otero Álvarez en el programa de doctorado "Estrategias para la mejora y control de la calidad de los alimentos de origen animal", informa favorablemente el depósito de la misma, dado que reúne las condiciones necesarias para su defensa.

Lo que firmo, en León a de de 2014 



\section{ADMISIÓN A TRÁMITE DE LA TESIS DOCTORAL}

El Consejo del Departamento de Higiene y Tecnología de los Alimentos, órgano responsable del programa de doctorado "Estrategias para la mejora y control de la calidad de los alimentos de origen animal" en su reunión celebrada el día de de 2014 ha acordado dar su conformidad a la admisión a trámite de lectura de la Tesis Doctoral titulada "Incidencia, Comportamiento y Control de Tipos Patógenos de Escherichia coli (STEC y EPEC) en Leche y Queso de Oveja", dirigida por la Dra. Dña. María Luisa García López y el Dr. D. José María Rodríguez Calleja, elaborada por Dña. Verónica Otero Álvarez, y cuyo título en inglés es el siguiente "Incidence, Behaviour and Control of Pathogenic Types of Escherichia coli (STEC and EPEC) in Ewes' Milk and Cheese".

Lo que firmo, en León a de de 2014.

El Secretario,

Fdo.: Bernardo Prieto Gutiérrez

ํo $\mathrm{B}^{\circ}$

El Director del Departamento

Fdo.: Andrés Otero Carballeira 



\section{FINANCIACIÓN}

Para llevar a cabo esta Tesis Doctoral, la doctoranda fue beneficiaria de una Ayuda del Programa de Formación de Profesorado Universitario (FPU) del Ministerio de Educación Cultura y Deporte.

Este trabajo ha sido financiado por la Junta de Castilla y León (Ayuda Grupo de Excelencia GR-155 y proyecto LE331A12_2) y por el proyecto AGL2011-26118/ALI del Plan Nacional de Investigación (Ministerio de Economía y Competitividad). 



\section{AGRADECIMIENTOS}

Quisiera expresar mi más sincero agradecimiento a mis directores, Dra. María Luisa García López y Dr. José María Rodríguez Calleja, por su tutela y apoyo, tanto profesional como personal, a lo largo de estos años.

A todos los miembros del Departamento de Higiene y Tecnología de los alimentos que de un modo u otro han colaborado en la elaboración de esta tesis. A los Doctores Jesús Ángel Santos Buerga y Andrés Otero Carballeira por su colaboración en el desarrollo de este trabajo. A Aurelia, Rosa, Dolores y Araceli por su gran apoyo en muchos momentos. Y especialmente a Elena, Elsa y Luisa, por todo.

Al Dr. Carlos Gonzalo Abascal y el Consorcio de Promoción del Ovino, porque sin su personal y ganadería este trabajo no podría haberse llevado a cabo.

A la Dra. Antonia Remacha del Hospital de León por su colaboración en este trabajo.

A la Dra. Cristina Nerín y todo su equipo (Instituto de investigación en ingeniería de Aragón), por permitirme trabajar con ellos durante un tiempo que resultó muy provechoso.

A todo el personal de la Unidad de Enterobacterias, Campylobacter y Vibrio del Instituto de Salud Carlos III de Madrid, especialmente a los Doctores Silvia Herrera León y Sergio Sánchez Prieto por hacer que me sintiera como en casa y por su ayuda, tanto durante la estancia como posteriormente, trasmitiéndome sus conocimientos y resolviendo las dudas que fueron surgiendo.

A mi familia, especialmente a mis padres y mi tía, porque siempre han hecho todo lo que estaba en su mano para que yo pudiera llegar hasta aquí, sin ellos no sería quien soy. 
A Jesús, por apoyarme durante tantos años y ayudarme a superar los momentos más duros de este proyecto de "ecoli", este camino ha sido más fácil gracias a él.

A mis amigas, por estar siempre. 
"Duda siempre de ti mismo, hasta que los datos no te dejen lugar a dudas" Louis Pasteur 

A mi familia 

ÍNDICE 

- INTRODUCCIÓN GENERAL. Antecedentes, Justificación y Objetivos. .1

- CAPÍTULO I: Incidencia de toxinas Shiga (Stxs), de genes stxs y de dos tipos patógenos de Escherichia coli (STEC y EPEC) en leche de oveja y otras muestras de origen ovino procedentes de explotaciones de Castilla y León .53

- CAPÍTULO II: Caracterización y estudio comparativo de cepas de Escherichia coli productor de toxinas Shiga (STEC) aisladas de leche de oveja, de sus explotaciones y de pacientes .85

- CAPÍTULO III: Caracterización y estudio comparativo de cepas de Escherichia coli enteropatogénico (EPEC) procedentes de leche de oveja, muestras ambientales y de pacientes.

- CAPÍTULO IV: Comportamiento de cepas de Escherichia coli productoras de toxinas Shiga (STEC) en leche de oveja almacenada a diferentes temperaturas y durante la elaboración y maduración de queso tipo Zamorano. 171

- CAPÍtULO V: Evaluación de dos películas activas para el control de cepas de Escherichia coli 0157:H7 en queso madurado de oveja (Zamorano) .203

- CONCLUSIONES .235

- ANEXOS 239

- Genetic Characterization of Atypical Enteropathogenic Escherichia coli Isolates from Ewes' Milk, Sheep Farm Environments, and Humans by Multilocus Sequence Typing and Pulsed-Field Gel Electrophoresis.

- Evaluation of two antimicrobial packaging films against Escherichia coli 0157:H7 strains in vitro and during storage of a Spanish ripened sheep cheese (Zamorano).

- Prevalence of Shiga toxin-producing Escherichia coli (STEC) in bulk tank ewes' milk and sheep farm environment. 



\section{INTRODUCCIÓN GENERAL.}

Antecedentes, Justificación y Objetivos 

Introducción general

\section{CONSIDERACIONES GENERALES SOBRE LA LECHE DE OVEJA}

\subsection{Composición química de la leche de oveja}

La leche es la "secreción mamaria normal de animales lecheros, obtenida mediante uno o más ordeños, sin ningún tipo de adición o extracción, destinada al consumo en forma de leche líquida o a elaboración ulterior" (Codex Alimentarius, 1999). En cuanto a su composición, existen diferencias tanto inter como intra especies. La composición y calidad higiénica de la leche varían en función de la raza, el individuo, la estación del año, la alimentación, el manejo, las condiciones ambientales, la región, la fase de lactación y el estado sanitario del animal lechero. La leche de ovino contiene mayor cantidad de sólidos totales y mayor cantidad de nutrientes que la de caprino o vacuno (Tabla 0.1) (Park et al., 2007; Raynal-Ljutovac et al., 2008).

Las características diferenciales de la leche de oveja respecto a la de otras especies son las siguientes (Tabla 0.1) (Park et al., 2007; Raynal-Ljutovac et al., 2008):

El carbohidrato mayoritario presente en la leche es la lactosa, representando el 49\% de los carbohidratos de la leche de oveja. El contenido en lactosa en leche de oveja es similar al presente en leche de vaca, mientras que los niveles de grasa y proteína son mucho mayores. Por esto, la lactosa en leche de oveja representa una proporción de los sólidos totales menor comparándola con la leche de vaca (22-27\% y $33-40 \%$, respectivamente). Otros carbohidratos que se encuentran en leche de ovino son oligosacáridos, glucopéptidos, glucoproteínas y otros en menor proporción. 
Tabla 0.1. Composición media de nutrientes básicos de las leches de cabra, oveja, vaca y humano (Park et al., 2007).

\begin{tabular}{lllll}
\hline Composición & Cabra & Oveja & Vaca & Humana \\
\hline Grasa (\%) & 3,8 & 7,9 & 3,6 & 4,0 \\
Sólidos no grasos (\%) & 8,9 & 12,0 & 9,0 & 8,9 \\
Lactosa (\%) & 4,1 & 4,9 & 4,7 & 6,9 \\
Proteína (\%) & 3,4 & 6,2 & 3,2 & 1,2 \\
Caseína (\%) & 2,4 & 4,2 & 2,6 & 0,4 \\
Albúmina, globulina (\%) & 0,6 & 1,0 & 0,6 & 0,7 \\
N. no proteico (\%) & 0,4 & 0,8 & 0,2 & 0,5 \\
Cenizas (\%) & 0,8 & 0,9 & 0,7 & 0,3 \\
Calorías/100 ml & 70 & 105 & 69 & 68 \\
\hline
\end{tabular}

Los lípidos son el componente más importante en cuanto al valor económico y las características nutritivas, físicas y sensoriales de los productos lácteos, además del más variable cuantitativa y cualitativamente en función de la fase de lactación, estación, raza, genotipo y alimentación. El grupo de lípidos mayoritario (en torno al 98\%) son los triacilgliceroles (TAG). Además de TAG, la leche de ovino presenta otros lípidos simples (diacilgliceroles, monoacilgliceroles, esteres de colesterol), lípidos complejos (fosfolípidos) y compuestos liposolubles (esteroles, hidrocarburos).

Los productos lácteos son fuente de proteínas de alta calidad biológica. El contenido en proteínas de la leche de oveja es superior al de otras especies (Tabla 0.1) aunque varía mucho, estando relacionado con la raza, la fase de lactación, la alimentación, el clima, la estación del año y el estado sanitario del animal. Su elevado porcentaje de nitrógeno proteico es responsable de la gran capacidad de coagulación de la leche de oveja. Las proteínas de la leche se clasifican en caseínas, proteínas del suero y proteínas menores.

La concentración de minerales en la leche no fluctúa demasiado, aunque puede variar ligeramente debido a la raza, dieta, individuo, fase de lactación y estado sanitario. En la leche de oveja, un $0,9 \%$ de sus cenizas son minerales (frente a un $0,7 \%$ en vacuno), siendo los niveles de $\mathrm{Ca}, \mathrm{P}, \mathrm{Mg}$, Zn, Fe y $\mathrm{Cu}$ mayores que en leche de vaca mientras que ocurre lo contrario con los niveles de K, Na y $\mathrm{Mn}$. 
Introducción general

En general, la leche de oveja contiene niveles más altos de vitaminas que la de los animales pertenecientes a las especies bovina y caprina, siendo una excepción el contenido en carotenos.

\section{2. Fuentes de contaminación microbiana de la leche de oveja}

Los niveles de microorganismos en la leche proporcionan información acerca del estado sanitario del animal lechero y sobre la higiene tanto del ordeño como de las fases posteriores. De hecho, en muchos países se ha conseguido un descenso de los recuentos, desde $\geq 10^{6} \mathrm{ufc} / \mathrm{ml}$ hasta $<2 \times 10^{4} \mathrm{ufc} / \mathrm{ml}$, como resultado de aplicar correctos programas de higiene (ICMSF, 2005). En la Unión Europea (UE), el límite microbiológico para la leche cruda de oveja es de $1,5 \times 10^{6} \mathrm{ufc} / \mathrm{ml}$ aunque si está destinada a la fabricación de productos lácteos sin previo tratamiento térmico, el límite es de $5 \times 10^{5}$ ufc/ml tal y como recoge en el Reglamento (CE) № 853/2004 (Anónimo, 2004). También se puede utilizar como índice de higiene de la leche de tanque el recuento de células somáticas. Este, en el caso de animales sanos, se encuentra por debajo de 100.000 células/ml de leche (ICMSF, 2005).

El número y el tipo de microorganismos presentes en la leche se ven directamente afectados por la acción de sustancias antimicrobianas presentes de forma natural y otros compuestos inhibidores exógenos como los antimicrobianos utilizados en sanidad animal. Las fuentes de contaminación de la leche incluyen (ICMSF, 2005):

\subsubsection{Interior de la ubre}

En animales sanos el tejido secretor de la ubre se encuentra libre de microorganismos, aunque la mucosa del canal del pezón contiene microorganismos que pueden pasar a la leche como estreptococos, estafilococos y micrococos $(<50 \%)$ además de Corynebacterium spp., coliformes, bacterias acidolácticas y otras bacterias. El nivel de contaminación a través de este canal varía entre $10^{2}$ y $10^{4} \mathrm{ufc} / \mathrm{ml}$ de leche.

La infección de la ubre también influye en la microbiología de la leche. Estas infecciones pueden detectarse en caso de que se trate de mamitis clínicas, pero existen mamitis subclínicas que no producen síntomas y por tanto más difíciles de 
Introducción general

detectar. Las mamitis dan lugar a un aumento de microorganismos (variable en función la importancia de la afección) y de los recuentos de células somáticas en la leche. Entre los microorganismos más frecuentemente asociados a mamitis subclínicas podemos encontrar: Staphylococcus aureus, Streptococcus agalactiae, S. dysgalactiae, S. uberis, estafilococos coagulasa negativos, Mycoplasma, coliformes, Escherichia coli, Corynebacterium bovis, Arcanobacterium pyogenes, Listeria monocytogenes, Pseudomonas aeruginosa y levaduras. Estos microorganismos son importantes porque dan lugar a cambios en la composición de la leche, algunos son patógenos para el hombre $y$, además, se pueden encontrar en leche residuos de los antimicrobianos utilizados para el tratamiento de mamitis.

Los rumiantes pueden infectarse también con patógenos agentes de zoonosis que llegan a la leche como Mycobacterium bovis, Brucella abortus, B. melitensis, $B$. suis, L. monocytogenes, Salmonella spp. o Coxiella burnetii.

\subsubsection{Superficie de la ubre y pezón}

Puede producirse contaminación durante el ordeño si la previa limpieza y desinfección de la ubre no se realiza de forma adecuada, aportando a la leche microorganismos en niveles que van de 100 a $1.000 \mathrm{ufc} / \mathrm{ml}$.

Esporulados como Bacillus spp. o clostridios procedentes de la tierra, pienso o de las heces llegan a la leche a través de esta vía. Aunque bacterias como Salmonella spp., Listeria spp., Campylobacter spp., Yersinia spp. o E. coli enteropatógenos pueden provocar mamitis, normalmente su presencia en leche se debe a contaminación a partir de las heces de animales infectados o portadores.

\subsubsection{Equipos y utensilios}

La limpieza y desinfección de los equipos utilizados en el ordeño, transporte y almacenamiento es esencial para el mantenimiento de la calidad higiénica de la leche. Pueden llegar a la leche a través de esta vía bacterias psicrotrofas Gram-negativas como Pseudomonas, Alcaligenes, Flavobacterium y Chromobacterium spp. o termodúricas que fácilmente colonizan las superficies de los materiales en contacto con la leche. 
Introducción general

Periodos prolongados de tiempo sin limpieza y desinfección adecuada de los equipos y medios de almacenamiento y transporte puede dar lugar a la formación de "biofilms". Los recuentos totales en estos "biofilms" se encuentran entre $10^{3}-10^{11}$ ufc/g y normalmente están constituidos por estreptococos (5-20\%), micrococos (20 $50 \%)$, corinebacterias $(10-16 \%)$, coliformes $(0,8-30 \%)$, otras bacterias Gramnegativas $(11-27 \%)$ y microorganismos aerobios formadores de esporas $(0,5-3,6 \%)$. Muchas de estas bacterias son termorresistentes y pueden dar problemas durante el procesado de la leche.

\subsubsection{Ambiente}

Esta contaminación ambiental puede ser principalmente a través del aire o del agua. En el caso del aire los microorganismos que predominan suelen ser micrococos, levaduras, esporas de Bacillus y Clostridium spp. y mohos. Los suministros de agua de las explotaciones a menudo contienen coliformes y organismos psicrotrofos, y cuando se utiliza en el aclarado de los equipos puede ser fuente de contaminación de la leche, por lo que este agua debe ser potable.

\subsubsection{Personal}

Personas enfermas y/o con hábitos higiénicos deficientes constituyen una fuente de transmisión de microorganismos tanto a la leche, como entre los animales del propio rebaño (mamitis).

\subsection{Importancia de la leche de oveja}

Según datos de la FAO (Food and Agriculture Organization), en el año 2012 había 1.169.004.916 cabezas de ovino en el mundo y 16.813.700 en España. Un total de 217.067.251 del censo mundial y 2.850.000 del español correspondían a cabezas de ganado ovino destinadas a la producción de leche (FAOSTAT, 2012).

A nivel nacional, según datos del "Anuario de estadística 2012" del Ministerio de Agricultura, Alimentación y Medio Ambiente (MAGRAMA), Castilla y León, con 3.259.186 cabezas, ocupaba el primer lugar entre las comunidades autónomas según su censo ovino, seguida de cerca por Extremadura (MAGRAMA, 2012). 
Introducción general

En cuanto a producción de leche de ovino, España ocupaba en 2012 el séptimo puesto a nivel mundial con 552.517 toneladas (FAOSTAT, 2012). Por comunidades autónomas, Castilla y León presentaba la mayor producción en 2012 con 366.537.000 litros (el 66\% de la producción nacional) (MAGRAMA, 2012).

\section{IMPORTANCIA DEL QUESO DE LECHE DE OVEJA}

La norma general del Codex Alimentarius para el queso (Codex Alimentarius, 1978) lo define como "el producto blando, semiduro, duro y extra duro, madurado o no madurado, y que puede estar recubierto, en el que la proporción entre las proteínas de suero y la caseína no sea superior a la de la leche, obtenido mediante: (a) coagulación total o parcial de la proteína de la leche, leche desnatada/descremada, leche parcialmente desnatada/descremada, nata (crema), nata (crema) de suero o leche de mantequilla/manteca, o de cualquier combinación de estos materiales, por acción del cuajo $u$ otros coagulantes idóneos, y por escurrimiento parcial del suero que se desprende como consecuencia de dicha coagulación, respetando el principio de que la elaboración del queso resulta en una concentración de proteína láctea (especialmente la porción de caseína) y que por consiguiente, el contenido de proteína del queso deberá ser evidentemente más alto que el de la mezcla de los materiales lácteos ya mencionados en base a la cual se elaboró el queso; y/o (b) técnicas de elaboración que comportan la coagulación de la leche y/o de los productos obtenidos de la leche que dan lugar a un producto final que posee las mismas características físicas, químicas y organolépticas que el producto definido en el apartado (a)." Esta misma norma establece una clasificación en función del contenido en humedad y las características de maduración tal y como refleja la Tabla 0.2. 
Tabla 0.2. Denominación del queso según sus características de consistencia y maduración (Codex Alimentarius, 1978).

\begin{tabular}{|c|c|c|}
\hline \multicolumn{2}{|c|}{ Según su consistencia: Término 1} & \multirow{2}{*}{$\begin{array}{l}\text { Según las principales } \\
\text { características de maduración: } \\
\text { Término } 2\end{array}$} \\
\hline HSMG $\%^{\mathrm{a}}$ & Denominación & \\
\hline$<51$ & Extraduro & Madurado \\
\hline $49-56$ & Duro & Madurado por mohos \\
\hline $54-69$ & Firme/Semiduro & No madurado/fresco \\
\hline$>67$ & Blando & En salmuera \\
\hline
\end{tabular}

${ }^{\mathrm{a}}$ HSMG \%: porcentaje de humedad sin materia grasa.

El queso en Castilla y León tiene un potencial productor de más de 90.000 toneladas, lo que supone en torno al $40 \%$ del total nacional, convirtiéndola en la primera Comunidad productora de España. La elevada producción quesera de esta Comunidad configura un sector industrial muy relevante en la economía autonómica, a través de un entramado de más de un centenar de industrias lácteas transformadoras y miles de empleados. El sector productor y las industrias lácteas regionales ocupan un lugar muy destacado en el panorama nacional, y el $15 \%$ de la facturación final de la industria agroalimentaria regional, solo por detrás del sector cárnico (MAGRAMA, 2011).

Según datos de la FAO, en el año 2012 España ocupaba el tercer puesto en el mundo como productor de queso de oveja con 62.328 toneladas y el segundo en la Unión Europea sólo por detrás de Grecia (FAOSTAT, 2012). La Consejería de Agricultura y Ganadería de la Junta de Castilla y Léon estima que casi 3 de cada 4 quesos de oveja españoles han sido producidos en Castilla y León. La mayor parte de la producción ovina lechera de Castilla y León se dedica a la fabricación de queso madurado elaborado con leche cruda, destacando la Denominación de Origen Protegida (DOP) Queso Zamorano y algunos tipos incluidos en la Marca Colectiva "Queso Castellano".

\section{GRUPOS PATÓGENOS DE Escherichia coli}

\subsection{Características generales de $E$. coli}

El género Escherichia, perteneciente a la familia Enterobacteriaceae, está formado por 7 especies, siendo Escherichia coli la especie tipo (http://www.bacterio.cict.fr/e/escherichia.html\#r, última visita 24 de Marzo de 2014). 
Esta bacteria fue aislada por primera vez en 1885 a partir de las heces de un niño por el pediatra austriaco Theodor Escherich (Welch, 2006).

E. coli es una bacteria Gram-negativa, anaerobia facultativa y generalmente móvil gracias a la presencia de flagelos peritricos. Sus medidas aproximadas son $2 \mu \mathrm{m}$ de largo y 0,5 $\mu \mathrm{m}$ de ancho. La mayoría de las cepas pertenecientes a esta especie crecen en un amplio rango de temperatura (10-46ㅇ) (Erickson \& Doyle, 2007; Farrokh et al., 2013) aunque la óptima oscila entre 37 y $42^{\circ} \mathrm{C}$. Respecto al $\mathrm{pH}$, se multiplica a valores de 5,5-8,0, aunque existen ciertas cepas que soportan un $\mathrm{pH}$ tan bajo como 2,0-3,0 (Welch, 2006; Farrokh et al., 2013). Es capaz de reducir los nitratos a nitritos y cuando crece en presencia de glucosa u otros carbohidratos produce ácido y gas. Por lo general son oxidasa, citrato, ureasa y $\mathrm{SH}_{2}$ negativos pero positivos para la producción de indol y la prueba del rojo de metilo. Además, la mayor parte de cepas de E. coli tienen capacidad para fermentar la lactosa y otros azúcares como D-manitol, D-sorbitol, L-arabinosa, maltosa, D-xilosa, trehalosa y D-manosa (Welch, 2006; Elizaquível et al., 2011).

E. coli se encuentra normalmente en el tracto intestinal del hombre y otros vertebrados. Rara vez da lugar a enfermedad excepto en individuos inmunocomprometidos o con enfermedades que dañan la barrera gastrointestinal (por ejemplo peritonitis), sin embargo existen grupos de cepas que han adquirido genes de virulencia específicos, lo que les ha permitido adaptarse a nuevos nichos y producir un amplio espectro de enfermedades en el hombre y los animales. Las cepas de los grupos patógenos de $E$. coli suelen presentar características fenotípicas diferentes a las que muestra la cepa tipo de esta especie. Un ejemplo de ello es E. coli 0157:H7 que, a diferencia de la mayor parte de cepas de E. coli, generalmente no tiene capacidad para fermentar el sorbitol. Otra característica bioquímica que distingue este serotipo es la incapacidad de producir $\beta$-D-glucuronidasa. Finalmente, un alto porcentaje de estas cepas presenta un tipo de hemólisis diferente a la $\alpha$-hemólisis asociada con $E$. coli (Paton \& Paton, 1998a; Kaper et al., 2004; Welch, 2006; Gyles, 2007; Pennington, 2010; Elizaquível et al., 2011). 
Introducción general

E. coli se caracteriza rutinariamente por la serotipificación, basándose en la determinación de los antígenos $\mathrm{O}$ (somáticos), $\mathrm{K}$ (capsulares) y $\mathrm{H}$ (flagelares). Hasta ahora se han reconocido más de 700 serotipos de E. coli. Algunos serogrupos y serotipos se asocian con determinados síndromes clínicos, pero la identificación de cepas patógenas depende de la detección de determinados factores de virulencia que se encuentran frecuentemente alojados en elementos genéticos móviles que pueden pasar de unas cepas a otras dando lugar a nuevas combinaciones de factores de virulencia (Kaper et al., 2004; Welch, 2006; Elizaquível et al., 2011).

\subsection{Características de los grupos patógenos de E. coli}

Las cepas patógenas de E. coli pueden dar lugar a enfermedades tanto intestinales como extraintestinales, concretamente existen tres tipos de infecciones: Infecciones del Tracto Urinario (UTI), meningitis neonatal y gastroenteritis. En el caso de los patógenos intestinales, existen seis grupos patógenos o patotipos (Figura 0.1): $E$. coli enteropatogénico (EPEC), E. coli enterohemorrágico (EHEC), E. coli enterotoxigénico (ETEC), E. coli enteroagregativo (EAEC), E. coli enteroinvasivo (EIEC) y E. coli difusoadherente (DAEC) (Kaper et al., 2004; Welch, 2006; Elizaquível et al., 2011).

\subsubsection{ETEC:}

Frecuentemente produce diarrea acuosa en humanos y animales que puede ser desde leve hasta severa, dando lugar a síntomas similares a los del cólera, produciendo deshidratación e incluso pudiendo provocar la muerte. Este patotipo produce diarrea en niños de países en vías de desarrollo, siendo también una de las causas de la diarrea del viajero. El principal factor de virulencia de ETEC es la producción de dos enterotoxinas, la enterotoxina termolábil (heat-labile enterotoxin -LT-) relacionada con la toxina de Vibrio cholerae, y la enterotoxina termoestable (heat-stable enterotoxin -ST-) (Kaper et al., 2004; Welch, 2006; Elizaquível et al., 2011). 
a

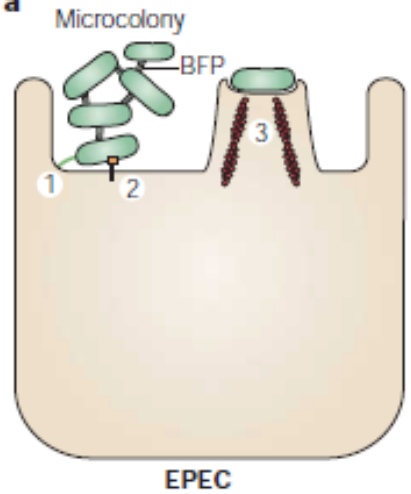

d

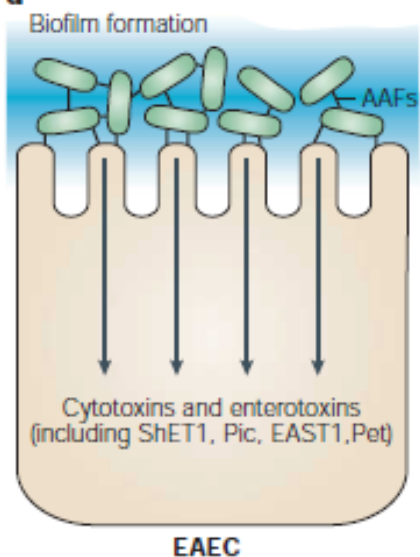

b

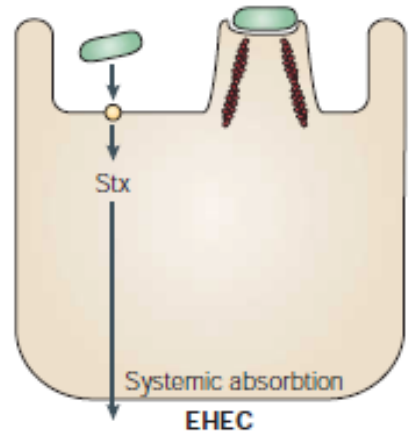

e

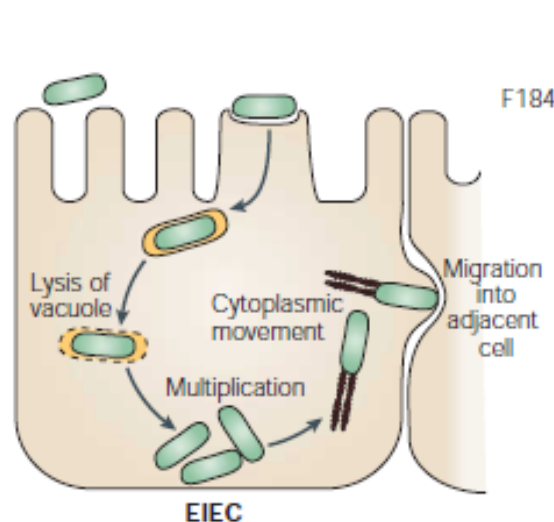

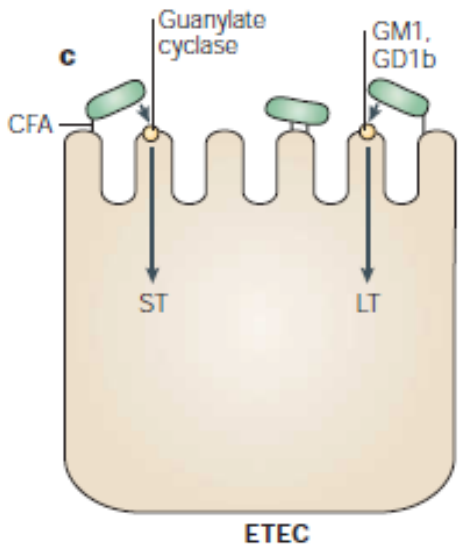

f

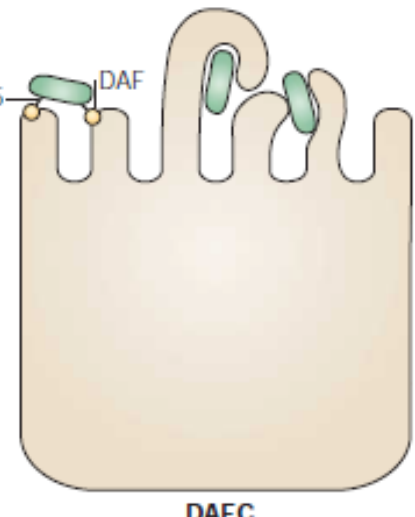

Figura 0.1. Esquema del comportamiento de los seis grupos de E. coli diarreagénicos (Kaper et al., 2004).

\subsubsection{EAEC:}

El grupo EAEC se define como el constituido por cepas de E. coli que no producen LT o ST y que se adhieren a las células HEp-2 con un patrón conocido como enteroagregativo, en el que las bacterias se adhieren unas a otras en una configuración de "ladrillos apilados". Este patotipo es responsable de diarrea acuosa que en ocasiones se presenta acompañada de dolor abdominal pero no fiebre. Las células no pasan al torrente circulatorio y son causa de diarrea persistente en niños y adultos tanto en países desarrollados como en vías de desarrollo.

\subsubsection{EIEC:}

Este patotipo se encuentra muy relacionado tanto patogénica como fenotípicamente con Shigella, compartiendo los principales genes de virulencia de esta 
bacteria. EIEC produce colitis inflamatoria invasiva y disentería con presencia de mucus y sangre en las heces, fiebre y dolor severo igual que en el caso de Shigella, aunque en la mayor parte de los casos únicamente da lugar a diarrea acuosa. Los genes asociados a su patogénesis se encuentran en un plásmido (Kaper et al., 2004; Welch, 2006; Elizaquível et al., 2011).

\subsubsection{DAEC:}

DAEC puede dar lugar a diarrea en niños menores de un año y se diferencia de otros E. coli diarreagénicos por su inconfundible fenotipo de adhesión a células Hep-2. Esta adhesión es provocada por la fimbria F1845, perteneciente a la familia Dr de adhesinas, que reconoce y se une al DAF (decay-accelerating factor), factor que normalmente protege a las células de posibles daños (Kaper et al., 2004; Welch, 2006; Elizaquível et al., 2011).

\subsubsection{EPEC:}

Este patotipo de E. coli se define como "cepas productoras de diarrea que originan lesiones intestinales de adhesión y borrado (A/E) pero que no poseen los genes que codifican para las toxinas Shiga (verotoxinas)". Es una de las principales causas de diarrea en niños en países en vías de desarrollo mientras que en países desarrollados su frecuencia ha disminuido (aunque siguen siendo una causa importante de diarrea). Se multiplican en el intestino delgado provocando diarrea acuosa que puede contener mucus pero no sangre. También pueden presentarse otros síntomas como vómitos, fiebre, malestar y deshidratación. Los síntomas suelen durar unos días, aunque se han descrito casos crónicos (Trabulsi et al., 2002; Welch, 2006; Elizaquível et al., 2011).

Los genes responsables de las lesiones de adhesión-borrado se encuentran en una isla de patogenicidad de $35 \mathrm{~kb}$ denominada "locus of enterocyte effacement" (LEE). En esta isla de patogenicidad se hallan los genes que codifican para la proteína externa de membrana (intimina -eae-), los genes esp (E. coli secreted proteins a, b y d), el gen que codifica para el receptor traslocado de intimina Tir (translocated intimin 
receptor) y los genes para la síntesis del sistema de secreción tipo III (Trabulsi et al., 2002; Kaper et al., 2004).

Se distinguen dos tipos de EPEC en función de la presencia o no de un plásmido de 70-100 kb, el plásmido "EPEC adherence factor" (EAF). Las denominadas EPEC típicas (tEPEC) poseen este plásmido EAF donde se localizan el grupo de genes bfps que codifican para el "Bundle Forming Pilus" (BFP), un pili de adherencia tipo IV. Por otro lado tenemos las EPEC atípicas (aEPEC), estas bacterias no poseen el plásmido EAF, aunque poseen otros factores de virulencia que no poseen las cepas tEPEC. Las tEPEC son la principal causa de diarrea infantil en países en vías de desarrollo, mientras que las aEPEC han sido causa de brotes de enfermedades diarreicas en países desarrollados tanto en niños como en adultos y parecen estar más estrechamente relacionados con el grupo de E. coli productor de toxinas Shiga (STEC). Las cepas aEPEC poseen reservorios tanto humanos como animales, mientras que en el caso de las cepas tEPEC normalmente aparecen asociadas a contaminación fecal humana (Trabulsi et al., 2002; Kaper et al., 2004; Welch, 2006; Elizaquível et al., 2011).

Para describir la patogénesis de EPEC se ha propuesto un modelo de tres fases que incluye una adherencia localizada, una transducción de señales y una adherencia íntima (Donnenberg \& Kaper, 1992). En la Figura 0.2 se detallan los genes implicados en esta patogénesis.

La primera fase de la patogénesis de EPEC consiste en la adhesión inicial de la bacteria a las células epiteliales asociada al pili BFP presente en el plásmido EAF de las cepas tEPEC. EI BFP da lugar a interacciones entre las bacterias produciendo agregados y contribuyendo a la difusión de la infección en el intestino. Esta es una adherencia localizada ( $A L)$. En el caso de las cepas aEPEC, que carecen del plásmido EAF, pueden producirse tres tipos de adhesión, una adhesión similar a la localizada ("localized-like adhesión" - LAL-) mediada principalmente por la intimina, una adherencia difusa (AD) mediada por la adhesina Afa o una adherencia agregativa (AA) mediada por una adhesina agregativa (Trabulsi et al., 2002; Chen \& Frankel, 2005; Hernandes et al., 2009). 


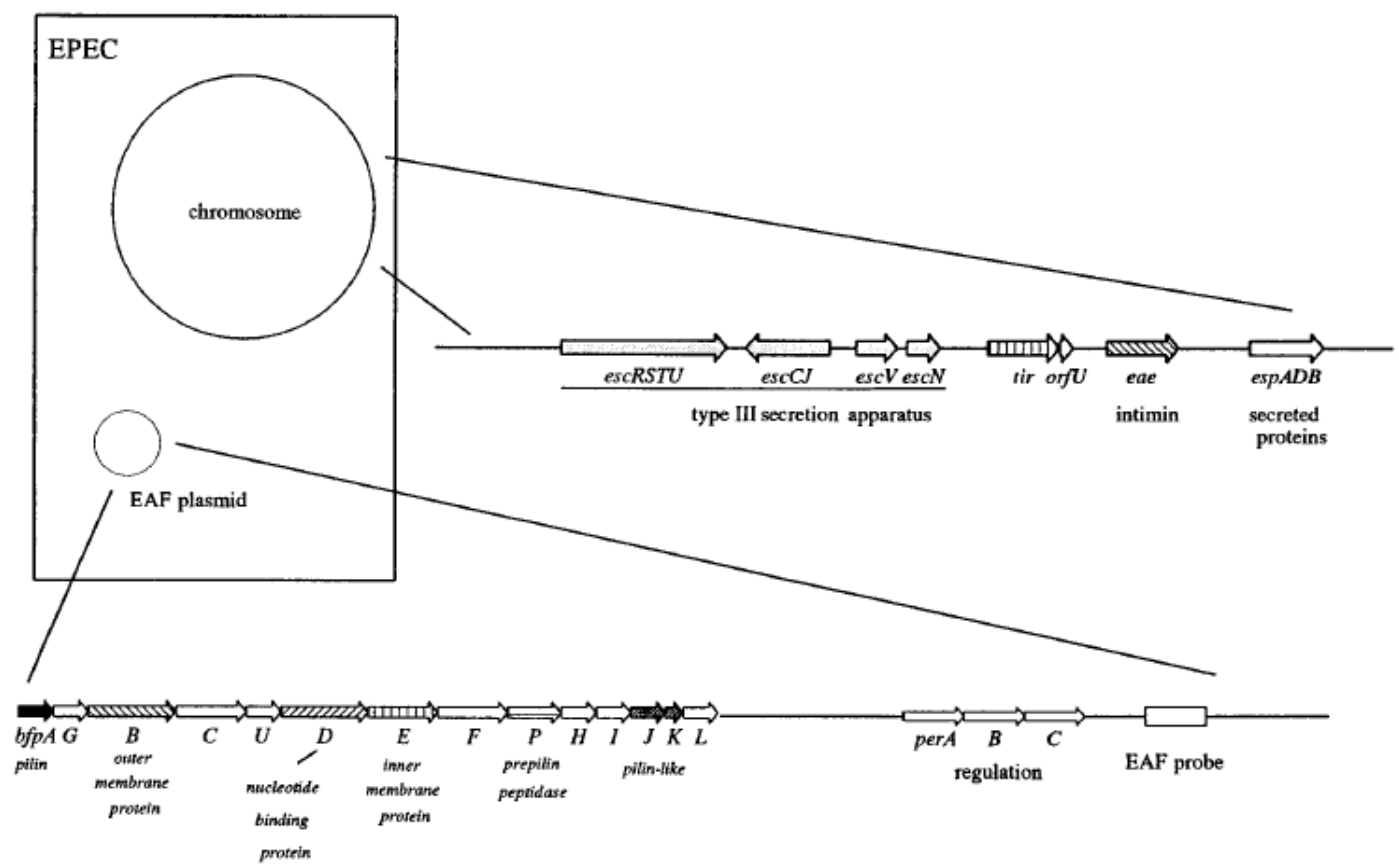

Figura 0.2. Esquema ilustrativo de los genes implicados en la patogénesis de EPEC (Nataro \& Kaper, 1998).

La segunda fase de la patogénesis es la transducción de señales. EPEC secreta un gran número de proteínas a través del sistema de secreción tipo III. Se han identificado 12 genes (esc y sep) en la isla de patogenicidad LEE que participan en la formación de este sistema. Las proteínas que se secretan a través de este sistema de secreción incluyen Tir, EspA, EspB y EspD, que son esenciales para la transducción de señales y la formación de las lesiones de adhesión y borrado ("attaching and effacing"; $\mathrm{A} / \mathrm{E})$.

La tercera fase de la patogénesis de EPEC consiste en el borrado de los enterocitos, la formación de un pedestal en la membrana del enterocito y la adhesión íntima de la bacteria a la célula (lesiones A/E), todo ello mediado por la intimina. La secuencia C-terminal de 280 aminoácidos de esta intimina (Int280) es muy variable y define gran cantidad de subtipos de esta proteína (relacionados con el tropismo por los tejidos). Cuando la intimina se adhiere a su receptor (Tir) se desencadenan los efectos patogénicos de EPEC en la célula (Chen \& Frankel, 2005; Hernandes et al., 2009). 


\subsubsection{EHEC:}

Este patotipo comparte con EPEC la habilidad de producir lesiones de adhesiónborrado gracias a la presencia de la isla de patogenicidad LEE, pero su característica principal es la capacidad de producir toxinas denominadas toxinas Shiga (Stxs -debido a la similitud demostrada con las toxinas de Shigella dysenteriae-) o verotoxinas (VT por el efecto citopático que producen en las células de la línea Vero-). Existen dos familias de toxinas Shiga, Stx1 y Stx2, que presentan un 55\% de aminoácidos homólogos (Kaper et al., 2004; Welch, 2006; Elizaquível et al., 2011).

EHEC puede dar lugar a diarrea no hemorrágica, colitis hemorrágica $(\mathrm{CH})$ y también al síndrome urémico hemolítico (SUH) y a la púrpura trombocitopénica. Las toxinas Shiga son producidas por la bacteria en el intestino grueso y ejercen una acción local al inducir apoptosis en las células epiteliales del intestino, dando lugar a diarrea hemorrágica, colitis hemorrágica, necrosis y formación de úlceras. Además estas toxinas pueden viajar a través del torrente sanguíneo hasta los riñones, allí dañan las células endoteliales del riñón y obstruyen la microvascularización a través de una toxicidad directa y una inducción de producción local de citoquinas y quimioquinas, dando lugar a inflamación renal. Este daño renal puede evolucionar al SUH, síndrome caracterizado por una triada de anemia hemolítica, trombocitopenia y fallo renal. Los niños menores de 5 años y los ancianos son los principales afectados por este síndrome (Kaper et al., 2004; Welch, 2006; Elizaquível et al., 2011).

La transmisión se produce a través de alimentos o de agua contaminados, persona a persona o por contacto con animales infectados. La baja dosis infectiva de esta bacteria (menos de 100 células ingeridas son suficientes para la producción de enfermedad) junto con su resistencia a la acidez la convierten en un destacado patógeno alimentario. El serotipo 0157:H7 es el más importante de este patotipo en Estados Unidos, Reino Unido y Japón, pero otros serotipos (particularmente los pertenecientes a los serogrupos 026 y 0111) son importantes en otros países (Kaper et al., 2004; Welch, 2006; Elizaquível et al., 2011).

Aunque existen más de 200 serotipos de cepas de E. coli capaces de producir toxinas Shiga, la mayor parte no poseen la isla de patogenicidad LEE y no están 
asociados a enfermedad en humanos. Esto ha llevado al uso del término de $E$. coli productoras de toxinas Shiga (STEC) para designar a cualquier cepa de $E$. coli que produce toxinas Stxs y el término EHEC únicamente para las cepas que, además de producir Stx, contienen la isla de patogenicidad LEE. La existencia de un gran número de cepas de E. coli capaces de producir Stxs se debe a que los genes que codifican para estas toxinas se transmiten como parte de fagos lamboides. Sin embargo, a pesar de lo mencionado anteriormente, existen cepas LEE-negativas capaces de producir enfermedad, demostrando por tanto que existen factores de virulencia adicionales (Kaper et al., 2004; Welch, 2006).

Siempre se ha considerado como principal reservorio de este patotipo el tracto intestinal de los bovinos, aunque las cepas STEC pueden detectarse en el tracto intestinal de otros animales domésticos, especialmente pequeños rumiantes. También se han aislado de los suidos domésticos, perros y gatos y algunas especies de animales silvestres (Paton \& Paton, 1998b).

\section{VIRULENCIA DE STEC}

\subsection{Serotipos patógenos}

Las cepas STEC se caracterizan mediante serotipificación. En función de la gravedad de la enfermedad que producen, los serotipos se clasifican en cinco patotipos designados con las letras A-E (Gyles, 2007):

A. Incluye las cepas 0157:H7 y 0157:NM que son considerados los serotipos más virulentos.

B. Incluyen los serotipos O26:H11, O103:H2, O111:NM, 0121:H19 y 0145:NM, similares a las cepas 0157 en producir enfermedades graves y brotes pero que ocurren con una menor frecuencia.

C. Está constituido por serotipos que están implicados en casos esporádicos de SUH con poca frecuencia pero no asociados con brotes. En este grupo se incluyen O91:H21 Y 0113:H21.

D. Comprende numerosos serotipos asociados con casos esporádicos de diarrea. 
E. Incluye un gran número de serotipos de STEC que no han sido asociados a enfermedad en humanos.

A continuación se revisa la patogénesis y los factores asociados con la virulencia de estas bacterias.

\subsection{Patogénesis de STEC}

La infección por STEC se produce por ingestión de comida o agua contaminados. Las cepas STEC, además de poseer una dosis infectiva muy baja (10-100 ufc), sobreviven en su paso a través del tracto gastrointestinal porque suelen ser resistentes a la acidez. Una vez en el intestino, y gracias a que poseen ciertos factores de virulencia, pueden ocasionar un proceso de mayor o menor gravedad (Paton \& Paton, 1998a; Gyles, 2007; Farrokh et al., 2013). En la Figura 0.3 se presenta un esquema del proceso.

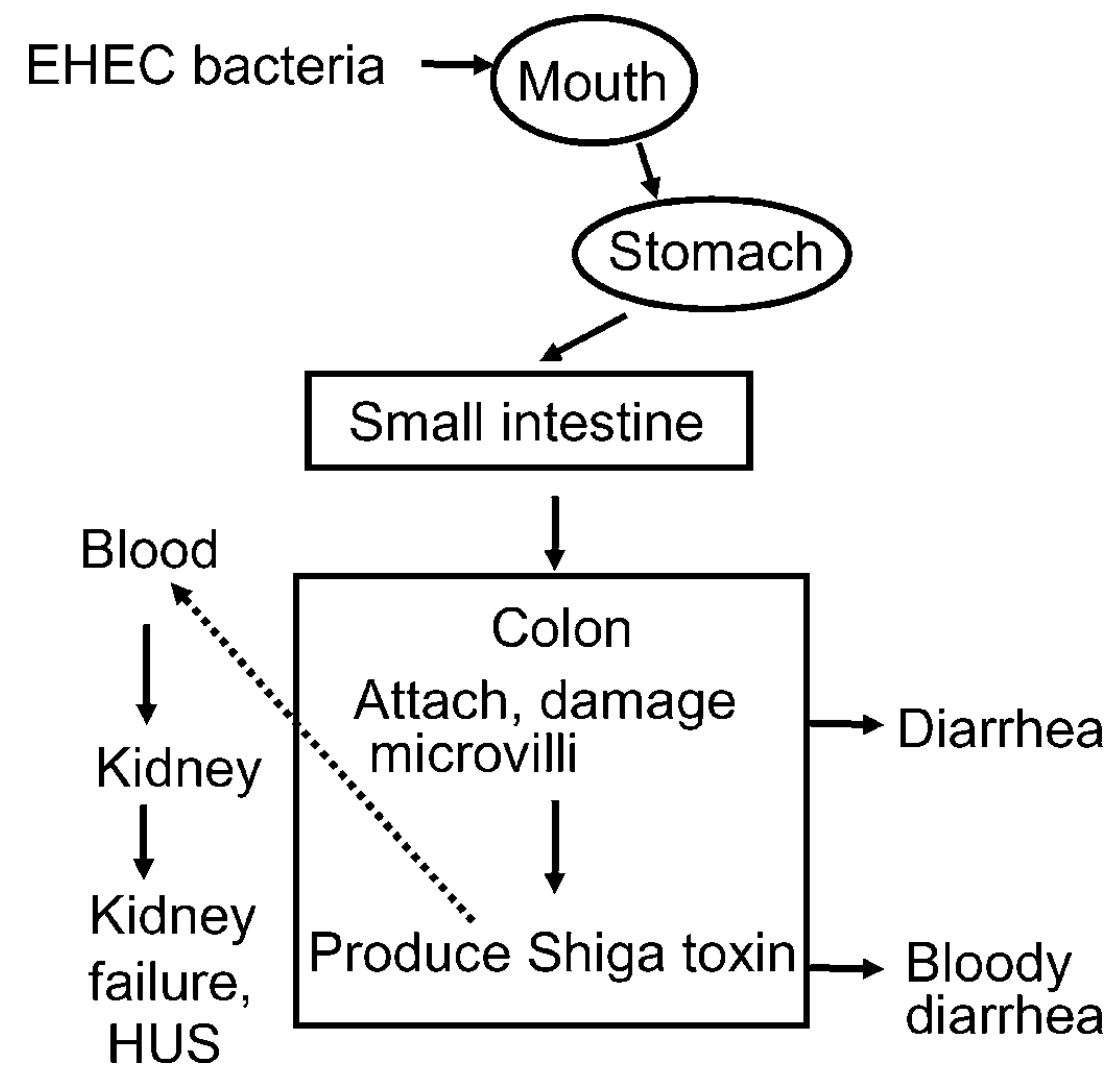

Figura 0.3. Esquema de la patogénesis de STEC en el hombre (Gyles, 2007). 


\subsubsection{Colonización del intestino}

Una vez en el intestino las cepas de STEC proceden a su colonización mediante la adhesión a las células epiteliales, principalmente en el colon, aunque también en la parte distal del intestino delgado. Se distinguen dos tipos de adherencia: adherencia difusa (AD) y adherencia localizada (AL). En el primer caso, las bacterias se distribuyen más o menos uniformemente sobre la superficie de las células epiteliales mientras que en el segundo, las bacterias forman microcolonias en determinadas zonas de la superficie de estas células (Paton \& Paton, 1998a).

Existen diferentes factores de virulencia asociados con esta adhesión a las células epiteliales del intestino. Entre estos factores de virulencia se encuentra la isla de patogenicidad LEE, presente en algunas cepas STEC y muy similar a la presente en las cepas EPEC, que da lugar a las denominadas lesiones de adhesión-borrado (A/E) (Paton \& Paton, 1998a; Gyles, 2007).

Las proteínas codificadas por la isla de patogenicidad LEE (Tir, EspF, EspG, EspH, EspZ) y otras proteínas no codificadas por esta isla de patogenicidad son traslocadas por el sistema de secreción tipo III. La proteína Tir se inserta en la membrana celular de la célula hospedadora actuando como receptor para la intimina, aunque algunos componentes de la célula hospedadora también pueden constituir un sitio de unión para la intimina. La proteína Tir, junto con otras proteínas desencadenan una señal en cascada que da lugar a cambios en la célula del epitelio intestinal (Gyles, 2007).

Existe una clara asociación entre la presencia del gen que codifica para la intimina (eae) en cepas STEC y la aparición de procesos graves como colitis hemorrágica y SUH. De hecho, la presencia del gen eae en aislados procedentes de animales está comúnmente asociada a cepas de serogrupos asociadas a enfermedad en humanos como 0157, 026, 0111, etc. (Paton \& Paton, 1998a). Se han descrito al menos 17 tipos de intimina $(\alpha 1, \alpha 2, \beta 1, \beta 2, \gamma 1, \gamma 2 / \theta, \delta / \kappa, \varepsilon, \zeta, \eta, \eta 2, \lambda$, $\mu$, etc.) en función de la heterogeneidad de la parte C-terminal de la molécula. La intimina $\gamma 1$ se asocia con serotipos de STEC muy patógenos como 0157:H7 y 0145:NM (Gyles, 2007). 
Otros factores de adherencia incluyen fimbrias, OMPs, el lipopolisacárido (LPS 0157) o el plásmido p0157. El plásmido de STEC de 60 MDa conocido como pO157 podría tener un papel en la adherencia de la bacteria a las células del epitelio intestinal, aunque se necesitarían más estudios para confirmarlo, ya que hasta ahora los resultados obtenidos en diferentes estudios son contradictorios (Paton \& Paton, 1998a).

\subsubsection{Papel de las toxinas Shiga (Stx)}

El factor de virulencia más importante de las cepas STEC son las toxinas Shiga (Stx). Existen dos tipos de Stxs denominadas Stx1 y Stx2. La molécula de la toxina Stx1, idéntica a la toxina Shiga tipo 1 producida por Shigella dysenteriae, presenta tres variantes antigénicas o subtipos (Stx1a, Stx1c y Stx1d), mientras que en el caso de la toxina Stx2 existen siete subtipos (Stx2a, Stx2b, Stx2c, Stx2d, Stx2e, Stx2f y Stx2g). Las cepas que producen la toxina Stx2 (más la presencia del gen eae) tienen mayor probabilidad de producir SUH que las que producen la toxina Stx1 o ambas. Concretamente los subtipos Stx2a, Stx2c y Stx2d son los más asociados con patologías graves en enfermedad humana (Gyles, 2007; Bergan et al., 2012; Farrokh et al., 2013).

Las toxinas Shiga pertenecen a la familia de toxinas $A B_{5}$, con una subunidad $A$ enzimáticamente activa y cinco subunidades $B(7,7 \mathrm{KDa})$ idénticas, colocadas formando un anillo en cuyo poro central se ancla el C-terminal de la subunidad A (Figura 0.4). Las subunidades B son responsables de la unión a los receptores celulares, concretamente se unen al glicoesfingolípido Gb3 permitiendo la internalización de la molécula de la toxina. Tras la unión de la toxina se produce su internalización por endocitosis y su transporte hasta el aparato de Golgi y al retículo endoplasmático (RE). Para que la subunidad A ejerza su efecto es necesaria la acción de una proteasa (furina) escindiendo la subunidad en dos fragmentos, uno enzimáticamente activo denominado $A 1(27,5 \mathrm{KDa})$ y otro más pequeño denominado $A 2(4,5 \mathrm{KDa})$ que, tras la acción de la proteasa, permanecerán unidos por un enlace disulfuro hasta su llegada al $\mathrm{RE}$, donde se producirá la rotura de este enlace debido las condiciones reductoras del RE. El fragmento A1 liberado es entonces traslocado al citosol donde ejercerá su acción citotóxica inactivando los ribosomas, al eliminar una adenina de la región 3’ del rARN 
28S. Como resultado se inhibe la síntesis proteica e incluso puede producirse la apoptosis de la célula (Gyles, 2007; Bergan et al., 2012).

Los genes que codifican las toxinas Shiga se encuentran localizados en el genoma de bacteriófagos lamboides denominados fagos-Stx. Estos fagos constituyen un grupo heterogéneo de elementos genéticos altamente móviles que pueden insertarse en sitios de unión específicos del cromosoma. Los fagos-Stx de cepas STEC pueden incluso infectar bacterias comensales del intestino, haciendo que puedan producir Stxs y por tanto agravando la enfermedad. Otra característica importante de los fagos-Stx es su estabilidad en el ambiente durante largos periodos de tiempo, pudiendo, como ya se ha dicho, insertarse en bacterias convirtiéndolas en productoras de toxinas Stxs (Bergan et al., 2012).

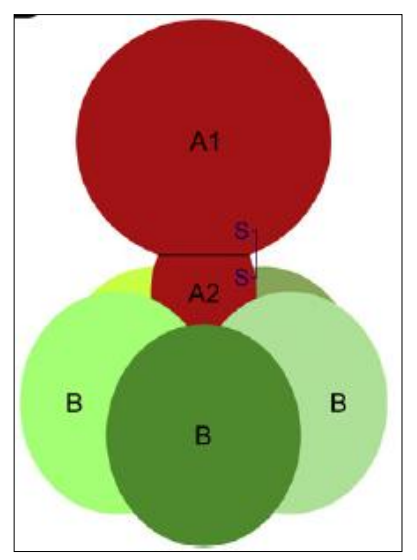

Figura 0.4. Representación esquemática de la estructura de las toxinas Shiga (Bergan et al., 2012).

La expresión del receptor para Stxs es un determinante de la susceptibilidad a la lesión celular, aunque también se requiere un transporte eficiente de la toxina. Tanto la cantidad como el tipo de Gb3 presente en las células influirán en la susceptibilidad a las toxinas Stx. En humanos, la expresión de Gb3 está restringida a ciertos tipos de células, principalmente en las células del epitelio y endotelio renales, células endoteliales de la lámina propia del intestino, plaquetas y linfocitos B (Gyles, 2007; Bergan et al., 2012).

La mayor parte de los síntomas de la colitis hemorrágica y del SUH se atribuyen a la acción de las toxinas Stx. La primera se asocia con lesiones en las células endoteliales de pequeños vasos sanguíneos del colon. El SUH se atribuye a lesiones 
del glomérulo renal debidas a daños en las células endoteliales, que se inflaman y se desprenden de la membrana basal formando trombos de fibrina que estrechan y ocluyen el capilar. La falta de aporte sanguíneo al glomérulo es la principal causa de la pérdida de la función renal, pero el daño del epitelio del glomérulo también contribuye (Gyles, 2007).

\subsubsection{Otros factores de virulencia}

4.2.3.1. Flagelina H7 y LPS 0157: Una característica destacada de la lesión intestinal en la infección con STEC 0157:H7 es la inflamación. Se ha propuesto que la flagelina H7 desempeña un importante papel en las señales proinflamatorias en las células epiteliales del colon. Se ha visto además que el LPS también participa en la respuesta inflamatoria a nivel vascular. EI LPS 0157 parece unirse a las plaquetas (en mayor proporción que el LPS de otras cepas EHEC) lo que desemboca en su activación (Gyles, 2007).

4.2.3.2. Enterohemolisina: Presente en la mayor parte de cepas STEC, la enterohemolisina pertenece a la familia de toxinas RTX y contribuye al desarrollo de enfermedad a través de la lisis de eritrocitos y la liberación de hemoglobina como fuente de hierro para la bacteria. También puede contribuir alterando la membrana de gran variedad de tipos celulares y con su capacidad para inducir la producción de citoquinas (Gyles, 2007).

4.2.3.3. Subtilasa: La subtilasa ( $S u b A B$ ) es una toxina $A B_{5}$ producida por ciertas cepas de $E$. coli asociadas a enfermedad en humanos. La SubAB está compuesta por una subunidad A (35 KDa) con actividad enzimática y cinco subunidades B (13 KDa) formando un pentámero que se une a receptores específicos de la superficie celular (Paton et al., 2004).

Tras la internalización en la célula, la SubAB llega al RE donde se une al chaperón BiP, provocando la activación de la quinasa del RE (similar a una proteinquinasa ARN dependiente) y la consecuente inhibición de la síntesis proteica que resultará finalmente en la apoptosis celular (Michelacci et al., 2013). 
Introducción general

Hasta ahora la SubAB ha sido identificada casi exclusivamente en cepas STEC, en particular en cepas que no presentan la isla de patogenicidad LEE. Existe la hipótesis de que la SubAB contribuye a la patogénesis de cepas STEC asociadas a enfermedad en humanos actuando sinérgicamente con las toxinas Stx. Se ha visto, en experimentos realizados con ratones, que la SubAB da lugar a alteraciones características del SUH producido por Stx, así como un extenso daño en la microvascularización y a trombosis y necrosis en cerebro, riñones e hígado (Gyles, 2007; Paton \& Paton, 2010; Michelacci et al., 2013).

Originariamente la SubAB fue aislada de una cepa de E. coli 0113:H21 (98NK2) procedente de un brote de SUH en el sur de Australia. En un plásmido de virulencia denominado p0113 se encontraba el operón que codifica para la subtilasa ( $s u b A B$ ) además de un gen que codifica para una adhesina autoaglutinante (saa), probablemente asociada a la colonización de las células del epitelio intestinal (Paton et al., 2001; Michelacci et al., 2013).

Se han descrito además dos cepas Stx-negativas capaces de producir SubAB (ED 32 y ED 591). Los genes subA y subB eran idénticos entre estas dos cepas y similares en un $90 \%$ a los presentes en el plásmido p0113 de la cepa 98NK2. Además estas cepas no presentaban la isla de patogenicidad LEE ni el gen saa, pero si albergaban cerca de los genes subAB un gen que codifica para un factor de invasión descrito en ETEC (tia). Se ha encontrado una región cromosómica idéntica con los genes subAB y tia en otras cepas STEC lo que sugiere la existencia de una isla de patogenicidad que contiene los genes subAB y tia (Tozzoli et al., 2010; Michelacci et al., 2013).

Por tanto existen dos variantes alélicas de los genes $s u b A B$, la presente en el plásmido p0113 junto con el gen saa denominada $s u b A B_{1}$ y la localizada en una isla de patogenicidad junto con el gen tia denominada $\operatorname{subAB}_{2}$ (Michelacci et al., 2013). 
Introducción general

\section{RESISTENCIA A ANTIBIÓTICOS}

Aunque las infecciones por STEC no suelen ser tratadas de forma agresiva con terapia antimicrobiana y muchas cepas son susceptibles a un gran número de antibióticos, estudios recientes demuestran que la resistencia a antibióticos de STEC está aumentando (Schroeder et al., 2002; Mora et al., 2005).

Existen principalmente cuatro causas por las que las bacterias pueden presentar resistencia a antibióticos (Martínez Álvarez, 2007):

- Presencia de enzimas específicos que modifican o inactivan el antibiótico antes o después de penetrar en la bacteria.

- Modificación de la membrana bacteriana, disminuyendo la permeabilidad al antimicrobiano.

- Expulsión activa del antibiótico al exterior de la bacteria.

- Síntesis de una molécula alternativa o modificación de la diana celular.

Estos mecanismos no solo se dan de forma aislada sino que pueden aparecer dos o más dando un nivel final de resistencia del microorganismo.

\subsection{Enzimas modificadores}

5.1.1. B-lactamasas: Las $\beta$-lactamasas (bla) son enzimas específicos que se unen a los antibióticos $\beta$-lactámicos hidrolizándolos para que no puedan ejercer su acción. Se conocen entre 350 y $400 \beta$-lactamasas, algunas asociadas a determinadas especies bacterianas y otras ampliamente distribuidas. Existen al menos diez subgrupos de genes que codifican para las $\beta$-lactamasas: TEM, SHV, PSE, OXA, PER, CTX-M, CMY, $A C C, D H A, K P C$.

5.1.2. Enzimas modificadores de aminoglicósidos: La resistencia a los aminoglicósidos se produce principalmente por enzimas capaces de modificar los grupos amino o hidroxilo de la molécula del antibiótico evitando así que este se una a las proteínas ribosomales diana y por tanto inhibiendo su acción. Existen tres tipos de enzimas: Oadeniltransferasas, $\mathrm{N}$-acetiltransferasas y O-fosfotransferasas. Entre los genes de Oadeniltransferasas se encuentran los del tipo aadA que median la resistencia a 
Introducción general

estreptomicina y espectinomicina, existen al menos seis subtipos aadA1, aadA2, aadA5, aadA7, aadA21, aadA22 y aadA23. Entre los genes de O-fosfotransferasas se encuentran el strA y el strB, únicamente median la resistencia a estreptomicina y normalmente se encuentran juntos y precedidos del gen sul2 (confiere resistencia a sulfonamidas).

5.1.3. Enzimas modificadores de fenicoles: Uno de los principales mecanismos de resistencia a fenicoles es la inactivación mediante la enzima cloranfenicol acetil transferasa (Cat) de tipo A o B.

\subsection{Expulsión activa del antibiótico}

5.2.1. Bombas de expulsión de tetraciclinas: Existen más de 35 genes que codifican resistencia a tetraciclina entre los que se encuentran tet $A$, tet $B$, tetD. Estos genes codifican para bombas de expulsión asociadas a membrana y poseen 12 segmentos transmembrana capaces de exportar tetraciclina, oxitetraciclina, clortetraciclina, y doxiciclina. Además, en el caso de la proteína TetB también es capaz de exportar minociclina.

5.2.2. Proteínas que expulsan fenicoles: Existen proteínas transportadoras específicas que expulsan de forma activa el cloranfenicol o cloranfenicol/florfenicol de las células bacterianas. Estas proteínas son $\mathrm{Cml}$, codificado por genes $\mathrm{cm} / \mathrm{A}$ y responsable de transporte de cloranfenicol, y Flo, codificado por genes floR y transporta tanto cloranfenicol como florfenicol.

\subsection{Síntesis de enzimas alternativos o modificación de la diana celular}

5.3.1. Resistencia al trimetoprim: Existen más de 30 genes, pero en todos ellos la resistencia se da gracias a la producción de una dihidrofolato reductasa ( $d h f r$ ) altamente resistente a este antibiótico. Existen dos tipos mayoritarios de estos genes, dhfrA y dhfrB.

5.3.2. Resistencia a sulfamidas: Los genes sul1, sul2 y sul3 codifican formas resistentes de la enzima dihidropteroico sintetasa. Esta enzima interviene en la síntesis del ácido 
Introducción general

dihidripteroico, compuesto intermediario en la formación del ácido tetrahidrofólico, cofactor necesario para la biosíntesis de bases nitrogenadas y aminoácidos.

5.3.3. Resistencia a quinolonas: La resistencia a quinolonas puede deberse a mutaciones puntuales en el gen gyrA, que codifica para la subunidad A de la ADNgirasa, ya que esta es la diana de estos antibióticos.

\subsection{Elementos genéticos móviles (EGMs)}

En la dispersión de la resistencia a agentes antimicrobianos participan elementos como el sistema integrón-casete genética, los transposones y los plásmidos.

5.4.1. Integrones: Los integrones son sistemas naturales de clonación y expresión que incorporan pautas abiertas de lectura (ORFs) y las convierten en genes funcionales. Continen una integrasa (int/), encargada de la recombinación entre el sitio de recombinación primario attl y el secundario attC. Este último junto con el ORF constituye lo que se denomina casete genética. La inserción de la casete genética en el sitio attl permite su expresión por un promotor que solapa con el gen intl (Carattoli, 2001; Martínez Álvarez, 2007).

Podemos diferenciar dos tipos de integrones: integrones de resistencia (RI) y superintegrones (SI).

Los RI presentan genes de resistencia a antimicrobianos y pueden encontrarse en transposones, plásmidos o en el cromosoma bacteriano. En función de la secuencia de aminoácidos de la integrasa distinguimos tres clases de Rls. Los mejor caracterizados y más ampliamente distribuidos son los integrones de clase 1 (Figura 0.5) que están constituidos por un segmento conservado en el extremo 5' (5'CS) que contiene el gen int/1 (integrasa) y otro segmento conservado en el extremo 3' (3'CS) que generalmente presenta el gen qacE $\Delta 1$, que confiere resistencia a antisépticos y desinfectantes, el gen sul1, que lo hace a sulfonamidas y una ORF de función desconocida (orf5). Las casetes genéticas de resistencia a antibióticos se insertan en el sitio attl, entre los segmentos $5^{\prime} \mathrm{CS}$ y $3^{\prime} \mathrm{CS}$, lo que se denomina región variable (RV) (Carattoli, 2001; Martínez Álvarez, 2007). 
Los SI son de mayor tamaño que los RI, se localizan en el cromosoma y contienen casetes genéticas con gran variedad de funciones (Martínez Álvarez, 2007).

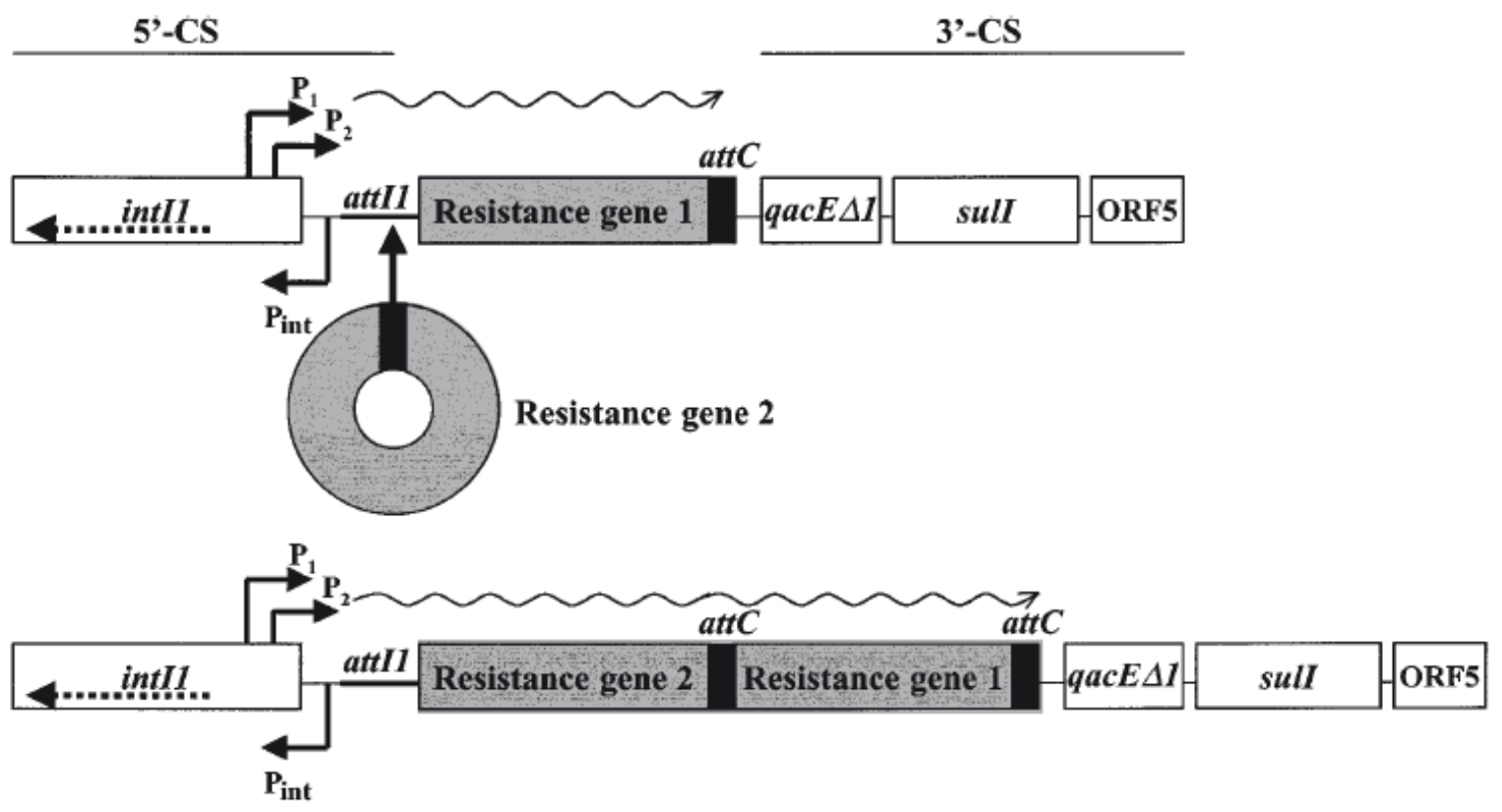

Figura 0.5. Representación esquemática de un integrón de clase 1 y modelo de inserción de una casete genética en este integrón (Carattoli, 2001).

5.4.2. Transposones: Son EGMs que, gracias a la presencia de la enzima transposasa y proteínas reguladores, promueven su propia translocación de un sitio donador a un sitio receptor sin necesidad de que exista homología entre ambos. Contienen genes accesorios que pueden conferir resistencia a antimicrobianos.

5.4.3. Plásmidos: Son elementos extracromosómicos con capacidad de replicación autónoma. Suelen codificar funciones no esenciales para la célula como virulencia o sistemas antimicrobianos que aportan una ventaja selectiva. Además, algunos presentan genes (tra) que participan en el proceso de conjugación. La transferencia puede ocurrir entre bacterias filogenéticamente distantes, lo que puede tener consecuencias evolutivas. Finalmente es importante destacar que pueden integrarse en el cromosoma bacteriano, con lo que la presencia de la región tra permite la movilización de ADN cromosómico entre bacterias. 


\section{TIPIFICACIÓN DE STEC Y EPEC}

Tradicionalmente la caracterización de cepas de E. coli comienza con la serotipificación. Ésta se realiza en base sus antígenos superficiales $\mathrm{O}$ (somáticos) y $\mathrm{H}$ (flagelares). Se dispone de sueros conteniendo anticuerpos frente a estos antígenos; concretamente, para los antígenos $\mathrm{O}$-del 1 al 181- y para los antígenos $\mathrm{H}$-del 1 al 56-. Sin embargo, hay que señalar que aunque pueden adquirirse "kits" comerciales para la tipificación de algunos serogrupos, la serotipificación suele estar restringida a los laboratorios de referencia (Kaper et al., 2004; Gyles, 2007; Farrokh et al., 2013).

El fagotipado es un método de subtipificación utilizado principalmente en las cepas STEC del serogrupo 0157. Consiste en la clasificación de una cepa en función de su respuesta lítica a un determinado número de bacteriófagos y permite, en estudios epidemiológicos, una rápida diferenciación entre aislados aunque la mayoría de las cepas pertenece a un limitado número de fagotipos (Khakhria et al., 1990). Por tanto, normalmente se combina con otras técnicas como la electroforesis en campo pulsado (PFGE).

Debido a su alto nivel de discriminación, la técnica PFGE está considerada como el método estándar para la tipificación de STEC, especialmente si se utiliza el protocolo de PulseNet (http://www.pulsenetinternational.org) (Farrokh et al., 2013).

En esta técnica se separan mediante electroforesis los fragmentos del cromosoma bacteriano generados tras la digestión del ADN con una enzima de restricción específica. La comparación del patrón, de entre 20 y 25 bandas, obtenido de los diferentes aislados permite determinar la relación entre las cepas.

Para la selección de cualquier procedimiento de tipificación es importante considerar la reproductibilidad tanto intralaboratorial como interlaboratorial. En el caso del PFGE ésta se ve influenciada por la preparación de la muestra de ADN, la elección de la enzima de restricción y las condiciones de electroforesis. La elección de la enzima de restricción es la variable más importante. El establecimiento de relaciones epidemiológicas y diferencias significativas entre aislados se basa en la habilidad para reconocer patrones de bandas de fragmentos de restricción, por lo que el ADN deberá 
ser digerido en un número manejable de fragmentos (no menos de 10 y no más de 25 - 30 fragmentos) con una distribución adecuada. Existen diferentes enzimas de restricción que cumplen lo mencionado para determinadas especies bacterianas y que se utilizan de modo estandarizado; en el caso de E. coli estas enzimas son Xbal, Blnl (Avrll), Notl y Sfil (Goering, 2010).

Los eventos genéticos que pueden influir en el patrón de bandas de PFGE son inserciones, deleciones, reordenamientos y sustituciones de una sola base. En función de si afectan o no los sitios de restricción, estos eventos pueden dar lugar a diferencias de hasta cuatro bandas respecto a la cepa origen. Una de las dificultades más comunes en los análisis epidemiológicos es la ausencia de la cepa origen, por lo que las diferencias entre aislados pueden ir de cuatro a seis bandas (Figura 0.6) (Goering, 2010).

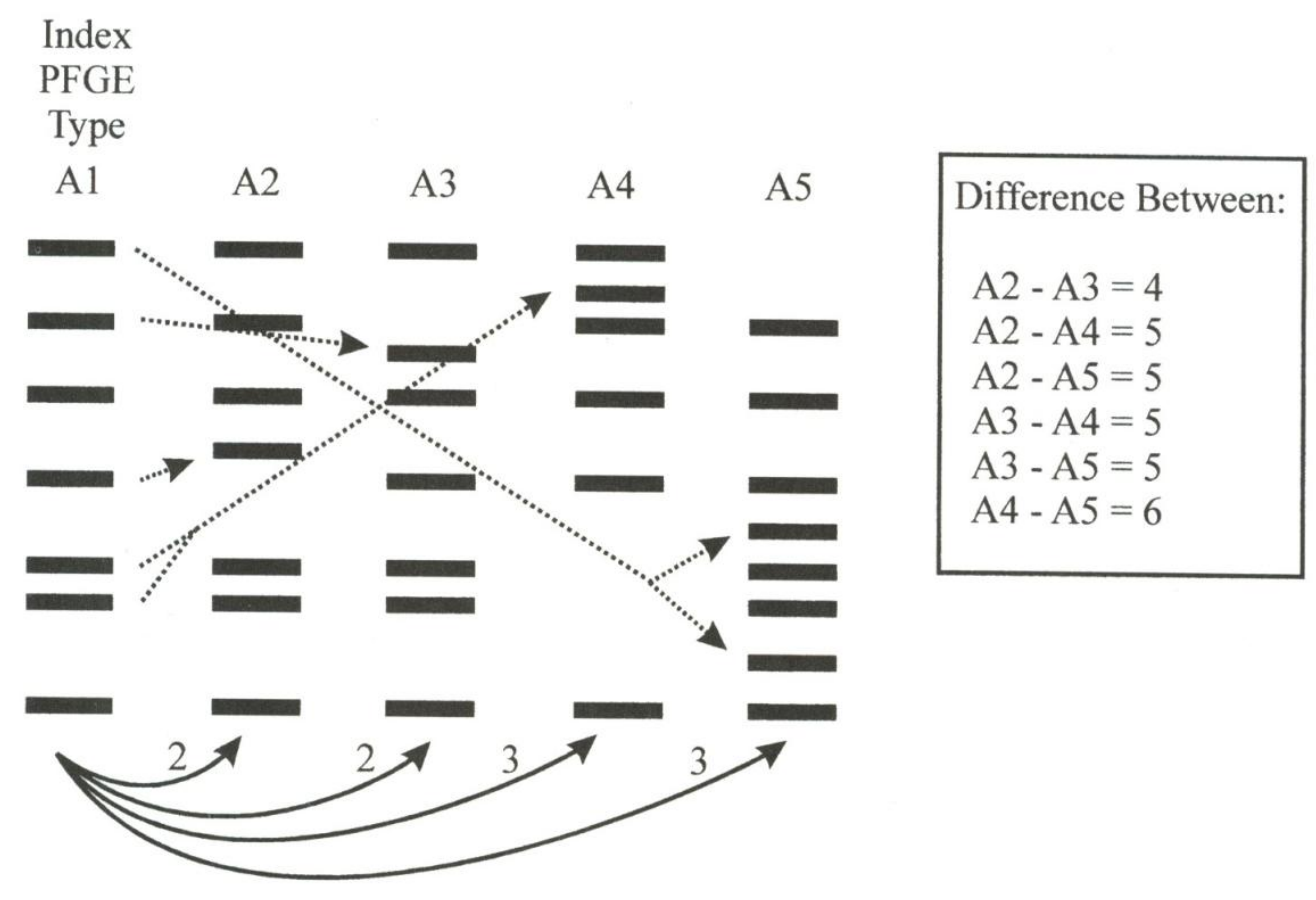

Figura 0.6. Ilustración de diferencias entre patrones de PFGE comparando entre aislados y con la cepa origen (Goering, 2004).

La reacción en cadena de la polimerasa (PCR) es el método más rápido, sensible y fiable para la detección de E. coli en muestras procedentes de alimentos, ambientales o clínicas. Además, puede utilizarse junto con métodos de cultivo convencionales o métodos de tipado molecular (Elizaquível et al., 2011). El uso de la PCR permite la detección de cepas STEC a través de la búsqueda de los genes que codifican 
para las toxinas Shiga (stx) en muestras microbiológicamente complejas (como heces o alimentos), incluso en caso de que el microorganismo no sea viable. La sensibilidad de la PCR en muestras de heces y alimentos se ha visto aumentada en gran medida mediante la realización de un enriquecimiento previo de estas muestras (Paton \& Paton, 1998a).

Además de protocolos de PCR para la detección de los genes que codifican para las toxinas Stxs (stx1 y stx2) (Pollard et al., 1990; Olsen et al., 1995; Paton \& Paton, 1998b) y sus variantes alélicas (Scheutz et al., 2012) existen protocolos para la detección de otros factores de virulencia (eae, EHEC-hlyA, etc.) importantes para determinar la capacidad de las cepas STEC de producir enfermedad en humanos y la gravedad de esta enfermedad (Paton \& Paton, 1998a).

También se han desarrollado métodos de PCR para la detección de determinados antígenos $\mathrm{O}$ (0157, 026, 091, 0103, 0111, 0121, 0145, 0146, etc.) (Desmarchelier et al., 1998; Perelle et al., 2004; Liu et al., 2007; Monday et al., 2007; Bugarel et al., 2010) y de antígenos $\mathrm{H}$ mediante la secuenciación del gen que codifica para este antígeno (fliC) (Machado et al., 2000) y poder así determinar el serotipo.

Para la tipificación de las cepas de EPEC se pueden emplear diferentes métodos; en esta tesis se ha utilizado el método MLST (Multilocus Sequence Typing) y el método PFGE.

Como ya se ha dicho, los métodos moleculares de tipificación se utilizan para la caracterización y la determinación de la relación existente entre cepas procedentes de diferentes orígenes. Uno de los más interesantes es el MLST, que se lleva a cabo mediante la obtención de las secuencias de ADN de fragmentos internos de siete genes "housekeeping" (entre 450 y 500 pb). Para cada uno de estos genes, las secuencias diferentes se corresponden con diferentes números de alelo. Así, los números de alelos obtenidos a partir de los 7 genes dan lugar a lo que se conoce como perfil de alelos o "sequence types" -ST-.

En la mayoría de los métodos de tipificación molecular, la relación entre aislados se representa gráficamente en un dendrograma. En el caso del MLST se 
utilizan las diferencias por pares entre perfiles de alelos de los aislados para construir dicho dendrograma. Aislados con perfiles de alelos idénticos se consideran miembros del mismo clon, mientras que aislados con perfiles de alelos similares que aparecen en un mismo grupo del dendrograma se consideran del mismo linaje o complejo clonal. Otra forma de analizar los datos del MLST es mediante el uso del algoritmo BURST ("Based Upon Related Sequence Types") que identifica complejos clonales, genotipos ancestrales (de origen) y patrones de descendencia evolutiva. En primer lugar, este algoritmo identifica los grupos clonales (aislados con genotipos relacionados) que incluirían todos los aislados que descienden de un antecesor común. A continuación determina el posible antecesor de cada grupo clonal y finalmente el patrón de descendencia evolutiva de todos los aislados del grupo clonal a partir de este antecesor (Hanage et al., 2004). La diversificación de un genotipo producirá inicialmente variantes que se diferencian únicamente en uno de los siete loci ("singlelocus variants" -SLVs-). La representación gráfica del algoritmo BURST es un diagrama formado por círculos concéntricos (diagrama de ojo de buey; Figura 0.7). En el círculo central aparece el antecesor mientras que en el primer círculo adyacente a este aparecerán los SLVs y en el segundo las variantes que difieran del genotipo de origen en dos loci ("double-locus variant" -DLVs-). Los ST que forman parte del grupo clonal pero no son SLVs o DLVs del ST de origen se denominan satélites y aparecerán unidos al ST al que más se asemejen. El análisis BURST nos proporciona una hipótesis acerca del origen y los patrones de descendencia dentro de grupos clonales que puede ser complementada con información adicional (Hanage et al., 2004).

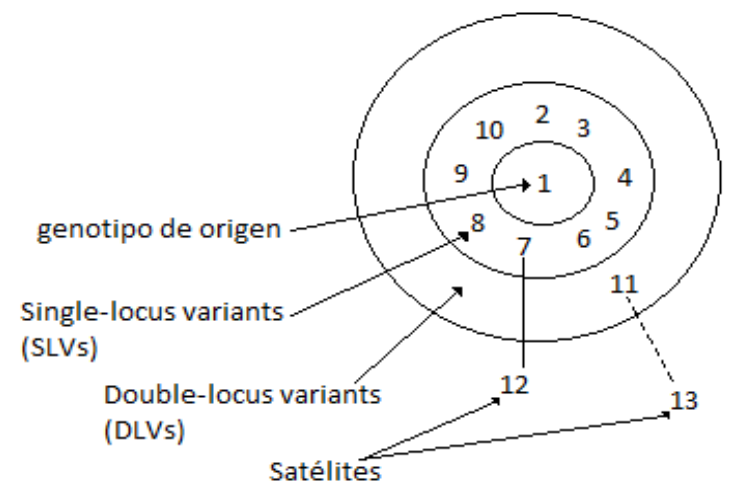

Figura 0.7. Diagrama de "ojo de buey" obtenido por el algoritmo BURST de un complejo clonal (Hanage et al., 2004). 
Introducción general

\section{IMPORTANCIA SANITARIA DE STEC Y EPEC}

\subsection{Datos epidemiológicos}

Según la "European Food Safety Authority" (EFSA, 2012b) en el año 2010 se diagnosticaron 4.000 casos de enfermedad por STEC en la Unión Europea (UE), representando un $12 \%$ más que en el año anterior. En ese año, la tasa de mortalidad por STEC fue del 0,39\% (ocho exitus letalis de un total de 2.077 casos confirmados) con otros 222 pacientes desarrollando SUH (5,5\% del total de casos). El 65,8\% de los casos de SUH se diagnosticaron en niños menores de cuatro años (un 42,5\% por cepas pertenecientes al serogrupo 0157 y un 19,2\% por cepas del serogrupo O26). La distribución de casos por STEC en el año 2010 presentaba un marcado patrón estacional, aumentando durante el verano y principios del otoño.

A nivel nacional, se declararon 37 casos (36 por E. coli $0157: \mathrm{H} 7$ ) en siete Comunidades Autónomas, dos de ellos en pacientes de Castilla y León (Instituto de Salud Carlos III, 2010).

En el año 2011 en la UE la EFSA informó de un brote de SUH. Hubo 3.126 casos de diarrea y 773 de SUH, con un total de 46 muertes (EFSA, 2011). Este brote fue debido a una cepa de $E$. coli perteneciente al serotipo 0104:H4 que poseía factores de virulencia comunes a los patotipos EAEC y STEC, factores de virulencia de E. coli patógenos extraintestinales y resistencia a numerosos antibióticos. El origen del brote fue atribuido a semillas de fenogreco importadas de África (aunque no se consiguió aislar la cepa de ninguna de las muestras analizadas) (Mora et al., 2011). Este caso nos da idea de la capacidad de las cepas de E. coli para adquirir factores de virulencia y convertirse en cepas altamente patógenas.

Una diferencia epidemiológica importante entre los serotipos típicos y atípicos de EPEC es su distribución geográfica. Los serotipos tEPEC han sido normalmente asociados con brotes de diarrea infantil en diferentes países. En el pasado, estos serotipos eran identificados frecuentemente en países desarrollados como causa de brotes y casos esporádicos de diarreas, pero en la actualidad son poco comunes. A partir del año 2000, en los países desarrollados predominan los serotipos de cepas 
aEPEC. Así, en el Reino Unido, las cepas que poseían el plásmido EAF (tEPEC) representaban únicamente el $10 \%$ del total de cepas de EPEC aisladas (Trabulsi et al., 2002).

En países en vías de desarrollo la situación no es tan clara. Estudios realizados en Brasil en las décadas de 1980 y 1990 mostraban una frecuencia bastante elevada de serotipos de cepas tEPEC. Sin embargo, trabajos posteriores encontraron una prevalencia baja de tEPEC y una frecuencia más elevada de aEPEC. Esto sugiere que los cambios que, en su momento se produjeron en países desarrollados, están produciéndose ahora en Brasil. Esto podría deberse a las mejoras en los tratamientos y en las condiciones sanitarias y también al control de las infecciones hospitalarias. Además, es posible, que el aumento en la frecuencia de cepas aEPEC pudiera tener un origen similar al que ocasionó la aparición y aumento de la frecuencia de E. coli 0157:H7 y otros serotipos STEC (Trabulsi et al., 2002).

\subsection{El ganado ovino como fuente de STEC y EPEC}

Los pequeños rumiantes se consideran un reservorio de STEC. Frecuentemente se han aislado cepas STEC tanto de corderos como de animales adultos en diferentes países (Australia, Brasil, India, Nueva Zelanda, España, Estados Unidos, etc). Algunas cepas de este origen pertenecían a los serotipos asociados con enfermedad en humanos pero otras carecían de importantes factores de virulencia (intimina, hemolisina, stx2, etc.) (Kaspar et al., 2009).

En muestras de ovino analizadas en la UE para STEC, se detectaron, en el año 2010 en Alemania y Hungría, porcentajes positivos del 2,4\% y 72,7\%, respectivamente (ninguna de las cepas pertenecía al serogrupo 0157, aunque se halló una cepa 091 en Alemania). Entre los años 2007 y 2010 se detectaron cepas STEC en muestras de ovino en otros países miembros de la UE como son Portugal, Austria y Suecia y algunas pertenecían al serogrupo 0157 (EFSA, 2012b).

Parece que en alimentos de origen ovino, la contaminación con STEC no suele ser excesivamente alta y un buen número de las cepas aisladas de leche cruda no pertenecen a serogrupos asociados con enfermedad en humanos ya que, por ejemplo, 
las cepas no-0157 son más frecuentes que las 0157. Sin embargo se ha observado que cepas STEC de este origen pueden sobrevivir durante el proceso de fabricación del queso. Por tanto, las variedades de queso elaboradas con leche cruda podrían representar un riesgo de enfermedad por STEC (Kaspar et al., 2009).

En un trienio (2007-2010), siete países de la UE informaron acerca de la presencia de STEC en carne de ovino, hallándose muestras positivas únicamente en Alemania. No se detectaron muestras positivas en leche de oveja y cabra en el período 2009-2010 pero sí en quesos elaborados con leche cruda y pasterizada de ovino en Francia y Eslovaquia (EFSA, 2012b).

Hay que considerar que los datos acerca de la incidencia de STEC tanto en muestras clínicas como en las obtenidas de animales y alimentos proceden de trabajos que utilizan diferentes métodos analíticos y de muestreo. Así, en muchos países se investiga sólo la presencia del serogrupo 0157 y son muy pocos los investigadores que utilizan métodos para la detección de cepas STEC no-O157 por lo que parece evidente que la importancia de estas últimas podría, seguramente, estar subestimada (EFSA, 2012b).

Por lo que respecta a EPEC, no se han detectado cepas tEPEC en animales lo que sugiere que es el hombre su reservorio (Trabulsi et al., 2002). Por otra parte, datos recientes ponen de manifiesto un incremento significativo de la incidencia de cepas aEPEC tanto en países desarrollados como en países en vías de desarrollo. Además, son numerosos los trabajos en los que se aíslan cepas aEPEC de animales sanos y enfermos pertenecientes a diversas especies entre las que se incluyen vacuno, pequeños rumiantes, porcino y aves de corral (Hernandes et al., 2009).

\subsection{Brotes debidos a STEC asociados con leche y productos lácteos}

Como ya se ha señalado, los rumiantes son el principal reservorio de STEC, por lo que estos animales pueden constituir el origen de la infección. Esta puede ocurrir por contacto directo con los animales o su ambiente o por consumo de agua o alimentos contaminados. También por contacto persona-persona (Tabla 0.3). Los brotes por STEC normalmente se asocian al consumo de carne poco cocinada, agua, 
productos lácteos elaborados con leche cruda, vegetales o alimentos listos para el consumo. En un $18,8 \%$ de los brotes producidos por cepas no-0157 el vehículo de transmisión no pudo ser identificado (Farrokh et al., 2013).

Tabla 0.3. Origen de los brotes de infección por cepas STEC 0157:H7 y no-O157:H7 (Kaspar et al., 2009).

\begin{tabular}{lll}
\hline Vehículo & STEC no-O157:H7 & E. coli O157:H7 \\
\hline Contacto con animales & $6,2 \%$ & $9,7 \%$ \\
Agua & $10,0 \%$ & $25,6 \%$ \\
Contacto persona-persona & $28,8 \%$ & $6,8 \%$ \\
\hline Lácteos & $10,0 \%$ & $12,5 \%$ \\
\hline Carne & $11,2 \%$ & $24,6 \%$ \\
Frutos & $6,2 \%$ & $9,2 \%$ \\
Otros Alimentos & $8,8 \%$ & $5,8 \%$ \\
Desconocidos & $18,8 \%$ & $5,8 \%$ \\
\hline
\end{tabular}

Como muestra la Tabla 0.3, el serogrupo 0157 parece ser la principal causa de los brotes ocasionados por STEC, pero el diseño y utilización de métodos para la detección de serogrupos STEC no-0157 está poniendo de manifiesto la importancia de estas cepas en infecciones alimentarias. Así, en Estados Unidos, en el año 2006, se declaró un aumento de entre el 20 y el 50\% en infecciones por STEC asociadas a cepas no-0157 (Farrokh et al., 2013). Creemos que es muy necesario diseñar métodos asequibles para la detección de cepas STEC no-0157 ya que las disponibles son muy laboriosas y poco útiles para un diagnóstico rutinario.

Un número significativo de brotes debidos a cepas STEC se ha relacionado con leche y productos lácteos de diferentes especies animales, sobre todo de vacuno. Hay datos procedentes de Europa, Estados Unidos y Canadá que atribuyen la infección al consumo de leche cruda (vaca y cabra), debiéndose la mayoría a E. coli 0157 aunque, en algunos casos, otros serogrupos/serotipos (O22:H8, O110:NM, O80:NM y 0145) fueron identificados como agentes causales. La mayoría de las cepas STEC responsables de los brotes producidos por quesos elaborados con leche cruda eran STEC 0157 aunque, como en el caso de la leche, otros serogrupos/serotipos (O27:H20, 0103, 026, 0145, 027:H20, 0104:H21) fueron identificados como agentes responsables de los procesos. También se han descrito brotes de infección por STEC 
Introducción general

asociados a leche y productos lácteos pasterizados. En estos casos, la presencia de cepas STEC se debió a un fallo en el tratamiento o a una contaminación posterior (Farrokh et al., 2013). Por lo que concierne a la leche de oveja y sus productos derivados, no se han declarado brotes aunque la presencia de cepas STEC en leche y queso sugiere que estos alimentos representan un riesgo (Kaspar et al., 2009; EFSA, 2012a).

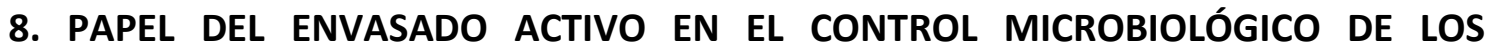 ALIMENTOS Y EN QUESO DE OVEJA}

\subsection{Envasado activo}

La mayor demanda por parte de los consumidores de alimentos mínimamente procesados, los cambios en la comercialización asociados a la globalización, la logística para captar consumidores, las nuevas técnicas de distribución (como la venta por internet), la aplicación de sistemas automatizados en los centros de distribución y los requisitos más estrictos respecto a la inocuidad de los alimentos han sido determinantes para innovar la tecnología del envasado de alimentos (Singh et al., 2011).

Entre estas innovaciones destaca el envasado activo, que puede definirse como la "forma de envasado en la que el envase, el producto y el ambiente interactúan para prolongar la vida útil o mejorar la seguridad o las propiedades sensoriales manteniendo la calidad del producto" (Appendini \& Hotchkiss, 2002; Kerry et al., 2006; Singh et al., 2011).

El envasado activo está diseñado para realizar otras funciones además de la de proporcionar una barrera entre el producto y el ambiente exterior, utilizando las posibles interacciones entre el envase y el alimento de un modo positivo para mejorar la calidad y aceptabilidad del alimento. Este tipo de envasado controla los mecanismos de deterioro del alimento aumentando su vida útil bien liberando sustancias de interés (antimicrobianos, antioxidantes, aromas; etc. -emisores-) y/o eliminando compuestos indeseables (oxígeno, etileno, olores, etc. -absorbedores-) del producto envasado o de 
su entorno (García et al., 2006; Kerry et al., 2006; Singh et al., 2011). También puede emplearse para controlar microorganismos patógenos.

La contaminación microbiana y el crecimiento de los microorganismos reducen la vida útil de los alimentos y aumentan el riesgo de enfermedad. Los métodos tradicionalmente utilizados para proteger los alimentos frente al crecimiento microbiano incluyen diversas estrategias como son el tratamiento térmico, la congelación, la refrigeración, el envasado a vacío o en atmósfera modificada o la adición de agentes antimicrobianos. El envase activo antimicrobiano actúa reduciendo, inhibiendo o retardando el crecimiento de microorganismos que pueden estar presentes en el alimento envasado o en el propio material de envasado, aumentando la vida útil y manteniendo la inocuidad y calidad del alimento (Appendini \& Hotchkiss, 2002; Kerry et al., 2006).

La aplicación del agente antimicrobiano al envase activo puede realizarse de varias formas (Appendini \& Hotchkiss, 2002):

- Colocando dentro del envase etiquetas, bolsitas o almohadillas conteniendo agentes antimicrobianos volátiles.

- Incorporando el agente antimicrobiano, volátil o no volátil, directamente en los polímeros.

- Recubriendo o adsorbiendo los agentes antimicrobianos en la superficie del material de envasado.

- Inmovilizando los agentes antimicrobianos en el polímero del material de envasado mediante enlaces iónicos o covalentes.

- Utilizando materiales de envasado como el quitosano con actividad antimicrobiana propia.

Un amplio rango de sustancias (ácidos orgánicos, bacteriocinas, extractos de especias, tiosulfatos, enzimas, proteínas, isotiocianatos, antibióticos, fungicidas, agentes quelantes, parabenos y metales) pueden tener efecto antimicrobiano al ser incorporadas en materiales de envasado. La mayoría de los materiales utilizados hasta ahora son plásticos sintéticos como: polietileno de baja/alta densidad (LDPE/HDPE), polipropileno (PP), etileno-acetato de vinilo (EVA), policloruro de vinilo (PVC), 
polietilentereftalato (PET), poliestireno (PS), etc. Además, existen materiales de envasado comestibles y biodegradables que pueden ser de origen animal o vegetal formados a partir de proteínas (colágeno, gelatina), polisacáridos (almidón, celulosa) o lípidos (ceras, resinas). Uno de los principales problemas del envasado activo reside en la liberación controlada del agente antimicrobiano presente en el material de envasado (Han, 2005; García et al., 2006; Singh et al., 2011).

Para obtener un envasado activo eficaz frente a los microorganismos, se debe de considerar tanto el microorganismo que se desea controlar como la composición del alimento a envasar. El compuesto antimicrobiano debe elegirse en función de su actividad, mecanismo de acción, composición química y las características de los microorganismos diana. La actividad de los agentes antimicrobianos que difunden desde el material de envasado al alimento dependerá, al menos en parte, de sus cinéticas de difusión, mientras que los agentes antimicrobianos unidos al polímero del material de envasado necesitan permanecer activos cuando se encuentran unidos a dicho polímero (Appendini \& Hotchkiss, 2002).

En general, la actividad antimicrobiana frente a los microorganismos "in vitro", es superior a la que se observa en los alimentos. Así, Los componentes de éstos limitan la actividad de los agentes antimicrobianos inhibiendo la difusión desde los polímeros del material de envasado. Además, componentes del material de envasado como lubricantes, estabilizantes, etc. pueden afectar negativamente a la actividad antimicrobiana del envase bien alterando la difusión o interactuando directamente con el agente antimicrobiano. Asimismo, debe de tenerse en cuenta la concentración del agente antimicrobiano en el film, el grosor del mismo y las propiedades físicas y mecánicas del envase una vez elaborado (Appendini \& Hotchkiss, 2002).

\subsection{Aceites esenciales}

Durante las últimas décadas se vienen investigando métodos naturales para la obtención de alimentos inocuos, siendo una de las posibilidades el empleo de aceites esenciales como agentes antimicrobianos. Los aceites esenciales están constituidos por una variedad de compuestos químicos que les proporcionan características como olor, sabor y actividad biológica. Son sintetizados por plantas y pueden obtenerse de 
cualquier parte de la misma (flores, brotes, semillas, hojas, ramas, cortezas, madera, frutas o raíces). Se conocen en torno a 3000 aceites esenciales, de los que unos 300 son importantes comercialmente (Burt, 2004).

Además de su actividad frente a las bacterias, los aceites esenciales o sus componentes pueden tener propiedades antivirales, antimicóticas, antitoxigénicas, antiparasitarias e insecticidas. Estas propiedades posiblemente están relacionadas con la función que ejercen estos compuestos en las plantas.

Para la producción comercial de aceites esenciales, el método de extracción utilizado más frecuentemente es la destilación por arrastre de vapor. Por otra parte, los aceites esenciales son compuestos volátiles y por tanto, deben ser almacenados en recipientes herméticos protegidos de la luz para evitar cambios en su composición

Los aceites esenciales pueden contener hasta 60 componentes individuales. Los hay mayoritarios que pueden constituir hasta el $85 \%$ de un aceite esencial, mientras que el resto se presenta como trazas. Los compuestos fenólicos son los principales responsables de la actividad antibacteriana de los aceites esenciales. Existe cierta evidencia de que los compuestos minoritarios también participan en la actividad de los aceites esenciales, posiblemente por producir un efecto sinérgico de los otros componentes.

La composición de los aceites esenciales de una planta en particular puede variar en función de la zona geográfica y el momento de la cosecha. Generalmente, los aceites esenciales presentes en plantas cosechadas durante la floración o inmediatamente después poseen una mayor actividad antimicrobiana. La composición de los aceites esenciales obtenidos de diferentes órganos de una misma planta también puede variar ampliamente (Burt, 2004).

La composición del aceite esencial de orégano (OR), utilizado en este estudio, se presenta en la Tabla 0.4. 
Tabla 0.4. Componentes mayoritarios del aceite esencial de orégano (Burt, 2004).

\begin{tabular}{llll}
\hline $\begin{array}{l}\text { Nombre común del } \\
\text { aceite esencial }\end{array}$ & $\begin{array}{l}\text { Nombre científico } \\
\text { de la planta de } \\
\text { origen }\end{array}$ & $\begin{array}{l}\text { Componentes } \\
\text { mayoritarios }\end{array}$ & $\begin{array}{l}\text { Composición } \\
\text { aproximada (\%) }\end{array}$ \\
\hline & & $\begin{array}{l}\text { Carvacrol } \\
\text { Oregano }\end{array}$ & $\begin{array}{l}\text { Trazas }-80 \% \\
\text { Trazas }-64 \%\end{array}$ \\
& Origanum vulgare & $2-52 \%$ \\
p-cimeno & Trazas $-52 \%$ \\
\hline
\end{tabular}

${ }^{a}$ Porcentajes de volátiles totales

Aunque el mecanismo de acción de los aceites esenciales frente a las bacterias no está totalmente identificado, parece que no puede atribuirse específicamente a un efecto concreto sino a la acción combinada de varios. La Figura 0.8 muestra un esquema propuesto por Burt (2004). Según esta autora, el carácter lipofílico de los aceites esenciales les permite unirse a los lípidos de la membrana celular desestabilizando su estructura y aumentando su permeabilidad. Esto genera la salida de iones y otros contenidos celulares lo que origina la muerte de la bacteria sin que necesariamente se haya producido la lisis.

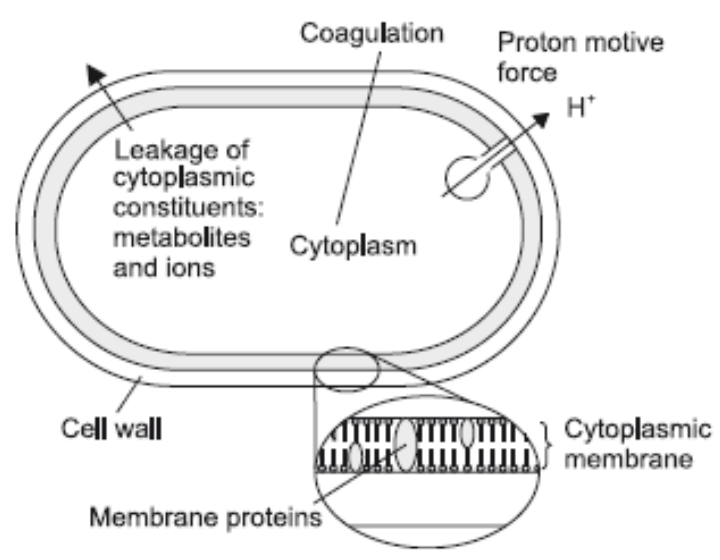

Figura 0.8. Localización y mecanismos de acción de los componentes de los aceites esenciales en la célula bacteriana (Burt, 2004).

Los aceites esenciales que poseen la máxima actividad antimicrobiana frente a bacterias patógenas de transmisión alimentaria contienen un alto porcentaje de compuestos fenólicos como carvacrol y timol (Figura 0.9) y se asume que actúan como el resto de compuestos fenólicos. Por tanto, se considera que sus efectos son la alteración de: la membrana citoplasmática, la fuerza protón-motriz (FPM), el flujo de 
electrones y el transporte activo así como la coagulación de ciertos componentes celulares. Para carvacrol y timol y otros compuestos fenólicos se ha demostrado que la localización y la cantidad de los grupos hidroxilo están relacionadas con su toxicidad ya que una mayor oxidación está asociada con una mayor actividad bactericida. Existen otros posibles efectos inhibidores como, por ejemplo, la interacción directa con las proteínas de la membrana citoplasmática que modifica la actividad de enzimas que regulan la producción de energía o la síntesis de compuestos estructurales. Aparentemente, los componentes de ciertos aceites esenciales interaccionan con las ATPasas e inhiben su actividad.

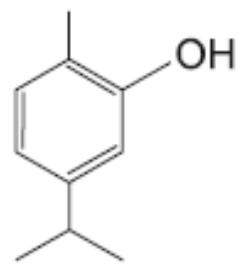

carvacrol

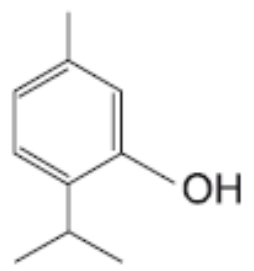

thymol

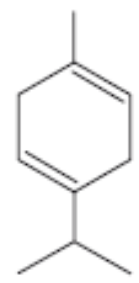

$\gamma$-terpinene

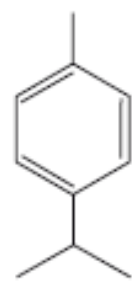

p-cymene

Figura 0.9. Estructura química de los componentes mayoritarios del aceite esencial de orégano (Burt, 2004).

Finalmente, los aceites esenciales son, en general, algo más activos frente a las bacterias Gram-positivas que frente a las Gram-negativas. Esto puede ser debido a la estructura de la pared celular, a la composición de la membrana externa de las bacterias y a su interacción con los aceites esenciales que, como ya se ha dicho, son de naturaleza lipofílica.

\subsection{Etil Lauroil Arginato/Arginato Laurico (LAE)}

EI LAE (etil- $\mathrm{N}^{\alpha}$-lauroil-L-arginato $\mathrm{HCL}$ ) es un agente antimicrobiano que puede utilizarse en alimentos ya que es efectivo frente a una amplia gama de bacterias tanto Gram-positivas como Gram-negativas así como frente a levaduras y mohos (Hawkins et al., 2009).

Es un tensioactivo catiónico derivado del ácido láurico y de la arginina cuya preparación y aplicación está descrita en la solicitud de la patente española ES 512643 
A1 (García Domínguez et al., 1983) y en la de la patente Europea. La fórmula de este compuesto es $\mathrm{C}_{20} \mathrm{H}_{41} \mathrm{~N}_{4} \mathrm{O}_{3} \mathrm{Cl}$ y tiene un peso molecular de 421,03 como sal monoclorhidrato y de 384,57 como base libre (Rodríguez et al., 2004; Ruckman et al., 2004).

Las propiedades catiónicas de este compuesto le permiten ejercer su acción antimicrobiana alterando la pared y membranas celulares produciendo la despolarización de la membrana citoplasmática y la consecuente pérdida de componentes del citosol. En bacterias Gram-negativas las alteraciones afectan tanto a la membrana citoplasmática como a la membrana externa, mientras que en el caso de Gram-positivas las alteraciones se observan en la membrana celular y en el citoplasma. En ninguno de los casos se observa lisis celular (Rodríguez et al., 2004).

En cuanto a su metabolismo, en estudios realizados en ratas y posteriormente en personas, se observó que el LAE es rápida y completamente metabolizado. Este compuesto es hidrolizado a LAS (lauroil arginina) y luego a arginina, resultando también en la formación de ácido láurico. Una vez que se ha formado, la arginina es un constituyente normal de la dieta que es metabolizado a ornitina, urea y dióxido de carbono por las rutas normales (Figura 0.10) (Ruckman et al., 2004; Hawkins et al., 2009).

Este compuesto ha sido evaluado por la FDA ("Food and Drug Administration") como antimicrobiano en alimentos y por el USDA ("US Department of Agriculture”) en productos cárnicos, concediéndole el estatus de GRAS ("Generally Recognised As Safe") para niveles de hasta $225 \mathrm{mg} / \mathrm{kg}$ en categorías alimentarias específicas (Hawkins et al., 2009).

La EFSA ha realizado estudios para revisar la exposición del LAE en la población para su uso como aditivo alimentario (EFSA, 2013), aunque su uso en Europa como aditivo alimentario no está permitido de momento (https://webgate.ec.europa.eu/sanco foods/main/index.cfm?event=substance.view\&i dentifier=370, última visita 24 de Marzo de 2014). 

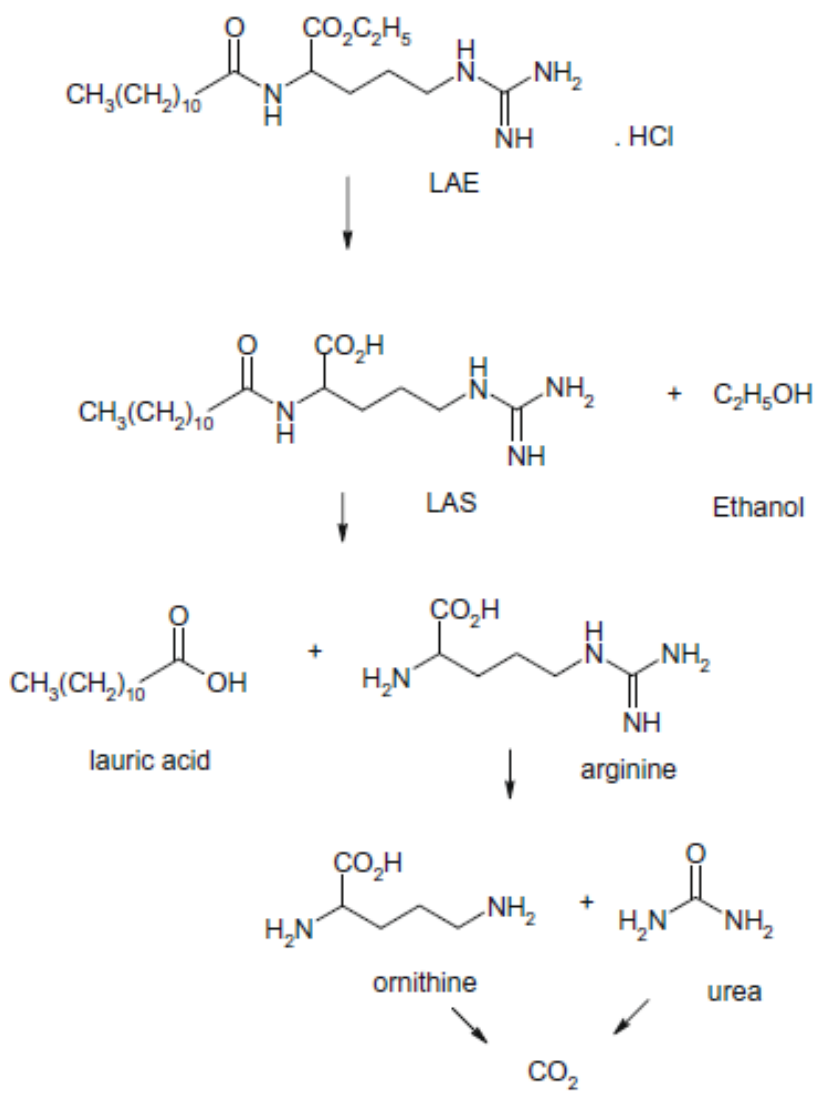

Figura 0.10. Ruta del metabolismo del LAE en mamíferos (Hawkins et al., 2009). 


\section{OBJETIVOS DE LA TESIS DOCTORAL}

El objetivo general de esta tesis doctoral fue conocer y mejorar la calidad de la leche de oveja producida por el Consorcio de Promoción del Ovino (CPO) y la del queso elaborado con esta leche, intentando minimizar el riesgo asociado a la presencia de cepas de E. coli productor de toxinas Shiga (STEC) y enteropatogénicas (EPEC).

Los objetivos concretos fueron los siguientes:

1. Conocer la importancia de la leche de oveja producida en Castilla y León como vehículo de STEC y EPEC.

2. Identificar las fuentes de contaminación de la leche con STEC y EPEC en las explotaciones de ovino, intentando establecer la relación existente entre cepas aisladas de leche de tanque, heces, agua, pienso y aire mediante el uso de técnicas moleculares.

3. Determinar si existía relación entre las cepas STEC/EPEC de origen ovino con cepas de origen humano aisladas de pacientes procedentes de la misma área geográfica.

4. Conocer el comportamiento de STEC en leche almacenada a diferentes regímenes de temperatura-tiempo y durante la fabricación y maduración de una variedad de queso de oveja tipo Zamorano.

5. Diseñar un sistema de envasado activo para controlar STEC en queso de oveja tipo Zamorano. 
Introducción general. Bibliografía

\section{BIBLIOGRAFÍA}

1. Anónimo. 2004. Reglamento (CE) № 853/2004 del Parlamento Europeo y del Consejo de 29 de Abril de 2004, por el que se establecen normas específicas de higiene de los alimentos de origen animal. D. O., L 139: 55.

2. Appendini, P. \& Hotchkiss, J. H. 2002. Review of antimicrobial food packaging. Innovative Food Science \& Emerging Technologies, 3: 113-126.

3. Bergan, J., Dyve Lingelem, A. B., Simm, R., Skotland, T. and Sandvig, K. 2012. Shiga toxins. Toxicon, 60: 1085-1107.

4. Bugarel, M., Beutin, L., Martin, A., Gill, A. and Fach, P. 2010. Micro-array for the identification of Shiga toxin-producing Escherichia coli (STEC) seropathotypes associated with Hemorrhagic Colitis and Hemolytic Uremic Syndrome in humans. Int. J. Food Microbiol., 142: 318-329.

5. Burt, S. 2004. Essential oils: their antibacterial properties and potential applications in foods-a review. Int. J. Food Microbiol., 94: 223-253.

6. Carattoli, A. 2001. Importance of integrons in the diffusion of resistance. Vet. Res., 32: $243-259$.

7. Chen, H. D. \& Frankel, G. 2005. Enteropathogenic Escherichia coli: unravelling pathogenesis. FEMS Microbiol. Rev., 29: 83-98.

8. Codex Alimentarius. 1999. Norma general del Codex para el uso de términos lecheros. CODEX STAN 206-1999. 
Introducción general. Bibliografía

9. Codex Alimentarius. 1978. Norma general del CODEX para el queso. Enmienda 2006, 2008. CODEX STAN 283-1978.

10. Desmarchelier, P. M., Bilge, S. S., Fegan, N., Mills, L., Vary Jr, J. C. and Tarr, P. I. 1998. A PCR specific for Escherichia coli 0157 based on the rfb locus encoding 0157 lipopolysaccharide. J. Clin. Microbiol., 36: 1801-1804.

11. Donnenberg, M. S. \& Kaper, J. B. 1992. Enteropathogenic Escherichia coli. Infect. Immun., 60: 3953-3961.

12. EFSA. 2013. Revised exposure assessment for ethyl lauroyl arginate for the proposed uses as a food additive. Disponible en:

http://www.efsa.europa.eu/en/efsajournal/pub/3294.htm. EFSA Journal, 11(6):3294.

13. EFSA. 2012a. Scientific Opinion on a review on the European Union Summary Reports on trends and sources of zoonoses, zoonotic agents and food-borne outbreaks in 2009 and 2010 - specifically for the data on Salmonella, Campylobacter, verotoxigenic Escherichia coli, Listeria monocytogenes and foodborne outbreaks. EFSA Journal, 10(6): 17-18.

14. EFSA. 2012b. European Centre for Disease Prevention and Control. The European Union summary report on trends and sources of zoonoses, zoonotic agents and foodborne outbreaks in 2010. EFSA Journal, 10(3): 161-189.

15. EFSA. 2011. Shiga toxin-producing E. coli (STEC) O104:H4 2011 outbreaks in Europe: Taking Stock. EFSA Journal, 9: 2390. 
Introducción general. Bibliografía

16. Elizaquível, P., Sánchez, G. and Aznar, R. 2011. Escherichia. In: Liu, D. (Ed.), Molecular detection of human bacterial pathogens. CRC Press, Boca Raton, FL, USA, pp. 869-879.

17. Erickson, M. C. \& Doyle, M. P. 2007. Food as a vehicle for transmission of Shiga toxinproducing Escherichia coli. J. Food Prot., 70: 2426-2449.

18. FAOSTAT. 2012. Datos estadísticos de FAOSTAT. Disponible en:

http://faostat3.fao.org/home/index.html. Última visita 24 de Marzo de 2014.

19. Farrokh, C., Jordan, K., Auvray, F., Glass, K., Oppegaard, H., Raynaud, S., Thevenot, D., Condron, R., De Reu, K. and Govaris, A. 2013. Review of Shiga-toxin-producing Escherichia coli (STEC) and their significance in dairy production. Int. J. Food Microbiol., 162 (2): 190-212.

20. García Domínguez, J. J., Infante, M. R., Erra, P. and Julia, M. R. 1983. N alpha-acil-Lalkylaminoguanidinic acids and their salts as surfactants with antimicrobial action. Spanish patent, Publication number: ES 512643 A1.

21. García, E., Gago, L. and Fernández, J. L. 2006. Informe de vigiliancia tecnológica. Tecnologías de envasado en atmósfera protectora. Fundación para el conocimiento madri+d. CEIM.

22. Goering, R. V. 2010. Pulsed field gel electrophoresis: a review of application and interpretation in the molecular epidemiology of infectious disease. Infection, Genetics and Evolution, 10: 866-875. 
Introducción general. Bibliografía

23. Goering, V. R. 2004. Pulsed-Field Gel Electrophoresis. In: Persing, D. H. e. a. (Ed.), Molecular Microbiology: Diagnostic principles and practice. ASM Press, Washington, D.C., pp. $185-196$.

24. Gyles, C. 2007. Shiga toxin-producing Escherichia coli: an overview. J. Anim. Sci., 85: E45-E62.

25. Han, J. H. 2005. Introduction to active food packaging technologies. In: Han, J. H. (Ed.), Innovations in food packaging. Academic Press, Londres, pp. 80-107.

26. Hanage, W. P., Feil, E. J., Brueggemann, A. B. and Spratt, B. G. 2004. Multilocus Sequence Typing: Strain characterization, populaion biology, and patterns of evolutionary descent. In: Persing, D. H. e. a. (Ed.), Molecular Microbiology: Diagnostic principles and Practice. ASM Press, Washington, D.C., pp. 235-243.

27. Hawkins, D. R., Rocabayera, X., Ruckman, S., Segret, R. and Shaw, D. 2009. Metabolism and pharmacokinetics of ethyl Na-lauroyl-L-arginate hydrochloride in human volunteers. Food and Chemical Toxicology, 47: 2711-2715.

28. Hernandes, R. T., Elias, W. P., Vieira, M. A. M. and Gomes, T. A. T. 2009. An overview of atypical enteropathogenic Escherichia coli. FEMS Microbiol. Lett., 297: 137-149.

29. ICMSF. 2005. Microorganisms in foods: 6 . Microbial ecology of food commodities. Kluwer Academic / Plenum publishers. New York. 
Introducción general. Bibliografía

30. Instituto de Salud Carlos III. 2010. Sistema de Información Microbiológica, Informe general 2010. Disponible en: http://www.isciii.es/ISCIII/es/contenidos/fd-servicioscientifico-tecnicos/fd-vigilancias-alertas/fd-sistema-informacionmicrobiologica/Informe_General_SIM_2010.pdf.

31. Kaper, J. B., Nataro, J. P. and Mobley, H. L. 2004. Pathogenic Escherichia coli. Nature Reviews Microbiology, 2: 123-140.

32. Kaspar, C., Doyle, M. E. and Archer, J. 2009. White paper on non-O157:H7 Shigatoxin producing E.coli from meat and non-meat sources. Disponible en: http://fri.wisc.edu/docs/pdf/FRI Brief NonO157STEC 4 10.pdf. Fri food safety reviews.

33. Kerry, J. P., O'grady, M. N. and Hogan, S. A. 2006. Past, current and potential utilisation of active and intelligent packaging systems for meat and muscle-based products: A review. Meat Sci., 74: 113-130.

34. Khakhria, R., Duck, D. and Lior, H. 1990. Extended phage-typing scheme for Escherichia coli 0157:H7. Epidemiol. Infect., 105: 511-520.

35. Liu, Y., DebRoy, C. and Fratamico, P. 2007. Sequencing and analysis of the Escherichia coli serogroup 0117, 0126, and 0146 O-antigen gene clusters and development of PCR assays targeting serogroup O117-, O126-, and O146-specific DNA sequences. Mol. Cell. Probes, 21: 295-302. 
Introducción general. Bibliografía

36. Machado, J., Grimont, F. and Grimont, P. A. D. 2000. Identification of Escherichia coli flagellar types by restrictionof the amplified flic gene. Res. Microbiol., 151: 535546.

37. MAGRAMA. 2012. Anuario de estadística. Disponible en:

http://www.magrama.gob.es/es/estadistica/temas/publicaciones/anuario-deestadistica/2012/default.aspx?parte=3\&capitulo=14. Última visita 24 de Marzo de 2014.

38. MAGRAMA. 2011. Cifras de los principales indicadores de la industria alimentaria por subsectores. Disponible en:

http://www.magrama.gob.es/es/alimentacion/temas/industriaagroalimentaria/Castilla Leon 2011 tcm7-270409.pdf.

39. Martínez Álvarez, N. 2007. Virulencia, resistencia y elementos genéticos móviles en serotipos no prevalentes de Salmonella enterica. Tesis Doctoral, Universidad de Oviedo. Departamento de Biología Funcional. Área de Microbiología.

40. Michelacci, V., Tozzoli, R., Caprioli, A., Martínez, R., Scheutz, F., Grande, L., Sánchez, S. and Morabito, S. 2013. A new pathogenicity island carrying an allelic variant of the Subtilase cytotoxin is common among Shiga toxin producing Escherichia coli of human and ovine origin. Clinical Microbiology and Infection.

41. Monday, S., Beisaw, A. and Feng, P. 2007. Identification of Shiga toxigenic Escherichia coli seropathotypes A and B by multiplex PCR. Mol. Cell. Probes, 21: 308311. 
Introducción general. Bibliografía

42. Mora, A., Blanco, J. E., Blanco, M., Alonso, M. P., Dhabi, G., Echeita, A., González, E. A., Bernárdez, M. I. and Blanco, J. 2005. Antimicrobial resistance of Shiga toxin (verotoxin)-producing Escherichia coli 0157: $\mathrm{H} 7$ and non-O157 strains isolated from humans, cattle, sheep and food in Spain. Res. Microbiol., 156: 793-806.

43. Mora, A., Herrera, A., López, C., Dahbi, G., Mamani, R., Pita, J. M., Alonso, M. P., Llovo, J., Bernárdez, M. I. and Blanco, J. E. 2011. Characteristics of the Shiga-toxinproducing enteroaggregative Escherichia coli O104: H4 German outbreak strain and of STEC strains isolated in Spain. Int. Microbiol., 14: 121-141.

44. Nataro, P. J. \& Kaper, J. B. 1998. Diarrheagenic Escherichia coli. Clinical Microbiology Reviews, 11: 142-201.

45. Olsen, J. E., Aabo, S., Hill, W., Notermans, S., Wernars, K., Granum, P. E., Popovic, T., Rasmussen, H. N. and Olsvik, O. 1995. Proves and polymerase chain reaction for detection of food-borne bacterial pathogens. Int. J. Food Microbiol., 28: 1-78.

46. Park, Y., Juárez, M., Ramos, M. and Haenlein, G. 2007. Physico-chemical characteristics of goat and sheep milk. Small Ruminant Res., 68: 88-113.

47. Paton, A. W. \& Paton, J. C. 2010. Escherichia coli subtilase cytotoxin. Toxins, 2: 215228.

48. Paton, A. W., Srimanote, P., Woodrow, M. C. and Paton, J. C. 2001. Characterization of Saa, a novel autoagglutinating adhesin produced by locus of 
Introducción general. Bibliografía

enterocyte effacement-negative Shiga-toxigenic Escherichia coli strains that are virulent for humans. Infect. Immun., 69: 6999-7009.

49. Paton, A. W., Srimanote, P., Talbot, U. M., Wang, H. and Paton, J. C. 2004. A new family of potent AB5 cytotoxins produced by Shiga toxigenic Escherichia coli. J. Exp. Med., 200: 35-46.

50. Paton, J. C. \& Paton, A. W. 1998a. Pathogenesis and diagnosis of Shiga toxinproducing Escherichia coli infections. Clin. Microbiol. Rev., 11: 450-479.

51. Paton, A. W. \& Paton, J. C. 1998b. Detection and characterization of Shiga toxigenic Escherichia coli by using multiplex PCR assays for stx1, stx2, eaeA, enterohemorrhagic E. coli hlyA, rfbO111, and rfbO157. J. Clin. Microbiol., 36: 598-602.

52. Pennington, H. 2010. Escherichia coli 0157. The Lancet, 376: 1428-1435.

53. Perelle, S., Dilasser, F., Grout, J. and Fach, P. 2004. Detection by $5{ }^{`}$-nuclease PCR of Shiga-toxin producing Escherichia coli 026, 055, 091, 0103, 0111, 0113, 0145 and 0157: H7, associated with the world's most frequent clinical cases. Mol. Cell. Probes, 18: $185-192$.

54. Pollard, D. R., Johnson, W. M., Lior, H., Tyler, S. D. and Rozee, K. R. 1990. Rapid and specific detection of Verotoxin genes in Escherichia coli by the Polymerase Chain Reaction. J. Clin. Microbiol., 28: 540-545. 
Introducción general. Bibliografía

55. Raynal-Ljutovac, K., Lagriffoul, G., Paccard, P., Guillet, I. and Chilliard, Y. 2008.

Composition of goat and sheep milk products: An update. Small Ruminant Res., 79: 57-

72.

56. Rodríguez, E., Seguer, J., Rocabayera, X. and Manresa, A. 2004. Cellular effects of monohydrochloride of I-arginine, Na-lauroyl ethylester (LAE) on exposure to Salmonella typhimurium and Staphylococcus aureus. J. Appl. Microbiol., 96: 903-912.

57. Ruckman, S. A., Rocabayera, X., Borzelleca, J. F. and Sandusky, C. B. 2004.

Toxicological and metabolic investigations of the safety of $\mathrm{N}$ - $\alpha$-Lauroyl-I-arginine ethyl ester monohydrochloride (LAE). Food and Chemical Toxicology, 42: 245-259.

58. Scheutz, F., Teel, L. D., Beutin, L., Pierard, D., Buvens, G., Karch, H., Mellmann, A., Caprioli, A., Tozzoli, R., Morabito, S., Strockbine, N. A., Melton-Celsa, A. R., Sanchez, M., Persson, S. and O'Brien, A. D. 2012. Multicenter evaluation of a sequence-based protocol for subtyping Shiga toxins and standardizing Stx nomenclature. J. Clin. Microbiol., 50: 2951-2963.

59. Schroeder, C. M., Zhao, C., DebRoy, C., Torcolini, J., Zhao, S., White, D. G., Wagner, D. D., McDermott, P. F., Walker, R. D. and Meng, J. 2002. Antimicrobial resistance of Escherichia coli $\mathrm{O} 157$ isolated from humans, cattle, swine, and food. Appl. Environ. Microbiol., 68: 576-581.

60. Singh, P., Wani, A. A. and Saengerlaub, S. 2011. Active packaging of food products: recent trends. Nutr. Food Sci., 41: 249-260. 
Introducción general. Bibliografía

61. Tozzoli, R., Caprioli, A., Cappannella, S., Michelacci, V., Marziano, M. L. and Morabito, S. 2010. Production of the subtilase AB5 cytotoxin by Shiga toxin-negative Escherichia coli. J. Clin. Microbiol., 48: 178-183.

62. Trabulsi, L. R., Keller, R. and Gomes, T. A. T. 2002. Typical and Atypical

Enteropathogenic Escherichia coli. Emerging infectious diseases, 8: 508.

63. Welch, R. A. 2006. The Genus Escherichia. In: Dworkin, M., Falkow, S., Rosenberg, E., Schleifer, K. and Stackebrandt, E. (Eds.), The Prokaryotes: A Handbook on the Biology of Bacteria: Vol. 6: Proteobacteria: Gamma Subclass. Springer, Singapore, pp. $60-71$. 


\section{CAPÍTULO I: Incidencia de toxinas}

Shiga (Stxs), de genes stxs y de dos tipos patógenos de

Escherichia coli (STEC y EPEC) en leche de oveja y otras muestras de origen ovino procedentes de explotaciones de Castilla y León 

Capítulo I. Introducción

\section{INTRODUCCIÓN}

\section{E. coli PRODUCTOR DE TOXINA SHIGA (STEC) EN LECHE}

El principal reservorio de STEC son los rumiantes domésticos y silvestres, aislándose de ganado bovino, caprino y ovino y de corzos, ciervos y gamos entre otras especies. Revisiones recientes (Baylis, 2009; Kaspar et al., 2009; Farrokh et al., 2013) han puesto de manifiesto la presencia de esta bacteria en explotaciones de leche y la relación existente entre cepas de este origen y casos y brotes de infección por STEC tanto por consumo de leche cruda como por productos elaborados con leche cruda.

Las cepas de STEC que causan colitis hemorrágica $(\mathrm{CH})$ y el síndrome urémico hemolítico (SUH) en humanos, forman parte de la microbiota normal de los rumiantes donde se comportan, en la mayor parte de los casos, como comensales aunque se han descrito casos de diarreas en terneros recién nacidos producidas por E. coli 0157:H7 e incluso de mamitis subclínicas (Meng et al., 2007). Su presencia en los alimentos, incluida la leche, es de origen fecal. Por tanto, el control de la higiene de los procesos y otras prácticas en establecimientos como mataderos o explotaciones lecheras es de gran importancia para minimizar el riesgo asociado a la presencia de esta bacteria en alimentos de origen animal (Kaspar et al., 2009; Farrokh et al., 2013).

La incidencia de STEC en leche cruda producida en la Unión Europea (UE) no ha variado mucho en los estudios realizados en la última década, encontrándose normalmente entre 0 y $2 \%$. Sin embargo, el desarrollo de nuevos métodos de detección de STEC basados en técnicas moleculares, los datos obtenidos en terceros países y la búsqueda de serotipos no-O157:H7, han hecho más compleja la interpretación de los datos sobre STEC presentes en leche. Así, parece que existen variaciones geográficas en cuanto a la prevalencia de distintos serotipos y genotipos y que los pequeños rumiantes son reservorios importantes en determinadas zonas (Meng et al., 2007; Farrokh et al., 2013).

\section{DETECCIÓN Y AISLAMIENTO DE STEC}

La existencia de más de 600 serotipos de STEC (Meng et al., 2013), se refleja en la publicación de numerosos protocolos de detección y aislamiento. Existen dos 
planteamientos diferentes para la detección de STEC en alimentos. Por un lado, técnicas que buscan los genes stxs y la producción de toxinas Stxs de STEC y, por otro, técnicas que detectan los serogrupos más frecuentemente asociados a la enfermedad como son: 0157, 026, 045, 091, 0103, 0111, 0121 y 0145. Ambos presentan inconvenientes ya que en el primer caso es frecuente aislar cepas que no producen enfermedad $y$, en el segundo, pueden no detectarse serotipos patógenos "raros" (O113:H21, 0174:H21) o serotipos patógenos emergentes como el 0104:H4 (Farrokh et al., 2013).

Para la detección de E. coli 0157:H7 se han desarrollado y utilizado métodos reconocidos como la norma UNE-EN ISO 16654:2001 (Anónimo, 2001), mientras que para los serogrupos no-0157, aunque se han descrito técnicas para los más frecuentes (026, 0103, 0111 y 0145) como las recogidas en la norma ISO/TS 13136:2012 (Anónimo, 2012), es necesario mejorarlas y, por supuesto, diseñarlas para otros serogrupos (Farrokh et al., 2013).

Para el aislamiento convencional de STEC se recurre a uno o varios de los siguientes pasos.

\subsection{Enriquecimiento}

En alimentos es necesario un paso previo de enriquecimiento ya que normalmente STEC está presente en un escaso número y le acompañan una gran variedad de microorganismos. Además, el enriquecimiento facilita la recuperación de bacterias lesionadas o estresadas. Se han descrito gran número de protocolos de enriquecimiento utilizando diferentes medios, agentes selectivos, temperaturas y tiempos de incubación (Vimont et al., 2006; Vimont et al., 2007; Baylis, 2008; Farrokh et al., 2013).

Para la detección de STEC tanto 0157:H7 como no-O157:H7, el método de enriquecimiento más utilizado consiste en inocular la muestra en caldo TSB (Tryptone Soya Broth) con una incubación a 35-37으 durante 16-24 horas (Vimont et al., 2006). Sin embargo, para evitar el efecto competidor de la flora acompañante se ha recomendado utilizar una temperatura de incubación de $42^{\circ} \mathrm{C}$, aunque esta temperatura puede interferir en la recuperación de las células dañadas (Baylis, 2008; Farrokh et al., 2013). Frecuentemente, se utilizan también agentes selectivos como telurito potásico o 
antibióticos; por ejemplo, novobiocina pero se ha comprobado que su uso y el de otros agentes selectivos pueden inhibir el crecimiento de algunas cepas STEC. Por ello, algunos autores recomiendan el uso de técnicas de enriquecimiento no selectivas (Vimont et al., 2007; Farrokh et al., 2013).

\subsection{Separación inmunomagnética}

Tras el enriquecimiento y antes de la siembra se puede utilizar la separación inmunomagnética (SIM) para concentrar las células de STEC pertenecientes a un determinado serogrupo. El uso de SIM para 0157 está muy extendido y considerado como el método estándar de detección de E. coli 0157 en alimentos (Anónimo, 2001). Posee un límite de detección de 1-2 ufc/25g. Existen métodos SIM para la detección de STEC noO157 como 026, 0103, 0111 y 0145, aunque no están estandarizados (Farrokh et al., 2013).

\subsection{Medios selectivos}

A diferencia de la mayoría de cepas de E. coli, las cepas 0157:H7 no fermentan el sorbitol, carecen de actividad $\beta$-glucuronidasa y son más resistentes a los compuestos cefixima y telurito. Basándose en estas propiedades se han desarrollado medios como el Sorbitol MacConkey Agar (SMAC) o su modificación suplementada con Cefixima y Telurito (CT-SMAC). Existen otros medios basados en reacciones cromogénicas para la detección de E. coli 0157:H7 pero no son útiles para la detección de otros serogrupos (Farrokh et al., 2013).

Otra característica importante es la capacidad de manifestar un tipo de hemólisis (enterohemólisis), que se utilizó para el desarrollo del medio "Enterohaemolisin Agar", preparado con eritrocitos lavados de ovino y suplementado con calcio. Tras la incubación durante 24 horas se observa una hemólisis característica (Beutin et al., 1989; Farrokh et al., 2013).

\subsection{Confirmación de colonias sospechosas}

Una vez obtenidos los aislados se puede confirmar que son STEC mediante varios procedimientos: el serotipado y la producción de toxinas Shiga (Stxs) o la presencia de los 
genes (stxs) que codifican para estas toxinas. Estos métodos incluyen técnicas serológicas, ensayos en cultivos celulares y métodos moleculares, como la reacción en cadena de la polimerasa - PCR- (Farrokh et al., 2013).

De forma tradicional, los aislados sospechosos eran confirmados bioquímicamente como E. coli y serotipados. El uso de sueros para el serotipado está restringido a laboratorios de referencia especializados y un reducido número de antígenos $\mathrm{O}$ y $\mathrm{H}$ pueden ser determinados mediante el uso de kits comerciales. Para la detección de la producción de toxinas Shiga existen kits comerciales de inmunoanálisis como el ProSpecT ${ }^{\circledR}$ Shiga Toxin (STEC) Microplate Assay (Remel, Lenexa, KS, USA). Alternativamente existen gran cantidad de genes de STEC que podemos detectar mediante PCR (stx, eae, antígenos $\mathrm{O}$ y $\mathrm{H}$, etc.).

\section{DETECCIÓN Y AISLAMIENTO DE E. coli ENTEROPATÓGENICO (EPEC)}

Como en el caso de STEC no-0157, no existe un protocolo estandarizado para su aislamiento y se lleva a cabo utilizando diferentes procedimientos (Araujo et al., 2002; Cortés et al., 2005; Aidar-Ugrinovich et al., 2007; Almeida et al., 2012).

Tradicionalmente las cepas de EPEC han sido identificadas por la expresión de ciertos serotipos epidemiológicamente relacionados con diarreas en niños. Actualmente se ha visto que existen gran cantidad de cepas de EPEC pertenecientes a serotipos que no habían sido descritos hasta el momento. Además, las cepas EPEC pueden presentar genes de virulencia no asociados clásicamente con este patotipo pero presentes frecuentemente en otros tipos patógenos de $E$. coli. Por tanto, métodos fenotípicos o genotípicos basados en la presencia (o ausencia) de estas características de virulencia deben ser utilizados para la identificación de cepas EPEC (Hernandes et al., 2009).

Las cepas de EPEC se identifican por la presencia de la región LEE (donde se encuentra el gen que codifica para la intimina -eae-) y la ausencia de los genes que codifican para las toxinas Shiga. Los métodos genotípicos incluyen técnicas de PCR para la detección de estos genes (Hernandes et al., 2009). 
Capítulo I. Introducción

\section{OBJETIVO}

El objetivo del trabajo presentado en este capítulo era determinar la incidencia de las toxinas Stxs, de los genes stxs y de cepas STEC y EPEC en leche de oveja y, en algunos casos, en el ambiente de la explotación. También, evaluar la eficacia de un método inmunoenzimático útil en muestras clínicas para su aplicación en la detección de Stxs en leche de oveja. 


\section{MATERIAL Y MÉTODOS}

\section{TOMA DE MUESTRAS}

En el transcurso de un año (Junio 2009-Junio 2010) se tomaron muestras de leche de tanque de 388 explotaciones de ganado ovino de la Comunidad Autónoma de Castilla y León pertenecientes al Consorcio de Promoción del Ovino (CPO). Las muestras recogidas se transportaron a temperatura de refrigeración. EI CPO es una cooperativa de segundo grado, la mayor del sector a nivel nacional. A esta cooperativa pertenecen explotaciones dedicadas a la cría de ganado ovino lechero principalmente de raza Assaf Española, aunque también hay rebaños de raza Castellana, Churra y Awassi. El sistema de producción es semiintensivo y la tasa reproductiva es próxima a un parto al año.

En función de los resultados obtenidos con las muestras de leche de tanque se seleccionaron diez explotaciones positivas de STEC, una de cada una de las rutas de recogida, con el fin de realizar una segunda toma de muestras. Esta vez consistió en dos muestreos en diferentes estaciones del año: el primero en Mayo del año 2011 (muestreo de primavera) y el segundo en Septiembre de este mismo año (muestreo de verano). Las muestras tomadas y el método utilizado se describen a continuación:

- Aire: se utilizó el muestreador de aire "Air Sampler RCS Plus" (Biotest Hycon, Dreieich, Alemania), recogiéndose diez litros de aire en cada uno de los establos de las explotaciones.

- Agua: se tomaron muestras del agua de bebida de los animales (500 ml) en recipientes de vidrio previamente esterilizados.

- Pienso: utilizando bolsas estériles desechables se tomaron muestras del alimento de los animales.

- Heces: mediante el uso del calcetín estéril para recogida de muestras fecales Sterisox (Sodibox Pont C'hoat, Nevez, Francia) se muestrearon las heces de los animales. Se utilizaron dos pares de calcetines por explotación, se dieron al menos cien pasos por cada par de calcetines muestreando los diferentes sectores de la granja (en especial la zona de descanso, ya que es el lugar en el que se acumula mayor cantidad de deposiciones). Los calcetines fueron previamente humedecidas con una solución estéril compuesta por $0,8 \%$ de 
cloruro sódico (Panreac Química, S.L.U., Barcelona, España) y 0,1\% de agua de peptona (Oxoid, Basingstoke, UK). Una vez terminado el muestreo, con cuidado de no desprender el material adherido, se depositaron los calcetines en bolsas estériles convenientemente etiquetadas.

Al igual que en el caso de las muestras de leche de tanque, todas estas se transportaron al laboratorio a temperatura de refrigeración.

\section{ENRIQUECIMIENTO DE LAS MUESTRAS}

Se realizó un enriquecimiento de todas las muestras tomadas. Para ello se utilizó el medio líquido Tryptone Soya Broth (TSB, Oxoid) al que se añadió 0,6\% de Yeast Extract (YE, Oxoid), incubándose a $42^{\circ} \mathrm{C}$ durante 18 horas (Vimont et al., 2006; Vimont et al., 2007; Baylis, 2008). El procedimiento con los distintos tipos de muestras fue el siguiente:

- Leche de tanque: se mezclaron $50 \mathrm{ml}$ de la muestra de leche con $450 \mathrm{ml}$ del medio de enriquecimiento.

- Aire: las muestras de aire fueron tomadas en tiras del medio general Tryptone Soya Agar (TSA, Oxoid). Se mezcló cada una de las tiras de TSA (Oxoid) con $50 \mathrm{ml}$ del medio de enriquecimiento y se homogeneizó en un BagMixer-400 blender (Interscience, Saint-Nom-la-Bretèche, Francia) durante un minuto y medio para su posterior incubación.

- Agua: Se filtraron $250 \mathrm{ml}$ del agua de bebida de cada una de las granjas a través de filtros de celulosa con un tamaño de poro de 0,45 $\mu \mathrm{m}$ (Pall Corporation, MI, USA). Se introdujeron los filtros en $50 \mathrm{ml}$ de la solución de enriquecimiento y se homogeneizó durante un minuto y medio.

- Pienso: se pesaron $25 \mathrm{~g}$ de pienso que se añadieron a $225 \mathrm{ml}$ del caldo de enriquecimiento y se homogeneizó durante minuto y medio.

- Heces: se desembalaron cuidadosamente los calcetines para no desprender el material fecal. Los cuatro calcetines pertenecientes a una misma explotación se sumergieron en $225 \mathrm{ml}$ de la solución de enriquecimiento y se homogeneizó durante un minuto y medio. 
Una vez transcurrido el tiempo de incubación (18 horas) se llevaron a cabo una serie de pruebas que se describen a continuación.

\section{DETECCIÓN DE TOXINAS Stx1 Y Stx2 EN LECHE DE OVEJA}

Para la detección de las toxinas en leche se utilizó el método ProSpecT ${ }^{\circledR}$ Shiga Toxin (STEC) Microplate Assay (Remel) siguiendo las instrucciones del fabricante. Esta prueba es un inmunoanálisis en fase sólida que permite la detección de Stx1 y Stx2 en muestras de heces o en cultivos fecales enriquecidos. Las muestras se añaden a los pocillos de la microplaca a los que se encuentra ligado el anticuerpo policlonal de conejo antitoxinas Shiga 1 y 2 . Si hay toxina en la muestra, ésta es "capturada" por el anticuerpo ligado. Los pocillos se incuban y posteriormente se lavan para eliminar el material no ligado. Se añade el conjugado enzimático (anticuerpo monoclonal antitoxinas Shiga 1 y 2 marcado con enzima peroxidasa de rábano). Los pocillos se incuban y posteriormente se lavan para eliminar el conjugado enzimático no ligado. Si la reacción es positiva, la toxina liga el conjugado enzimático al pocillo. Finalmente se añade el sustrato para la enzima, tetrametilbencidina (TMB). Si la reacción es positiva aparecerá un producto de reacción coloreado que se puede detectar visualmente o mediante una lectura espectrofotométrica midiendo la densidad óptica (D.O.) a longitudes de onda de 450 o 630-650 nm. Se realizaron las lecturas con un espectrofotómetro Multiskan FC microplate (Thermo Fisher Scientific Inc, Waltham, MA, USA). Se eligió la lectura de los resultados a $450 \mathrm{~nm}$ y se interpretaron así: Positivo: D.O. > 0,150; Negativo: D.O. < 0,100; Dudoso: D.O. entre 0,100-0,150.

Como pruebas control, se inoculó leche de oveja pasterizada y sin pasterizar con diferentes niveles de la cepa de la Colección Española de Cultivos Tipo (CECT) E. coli 0157:H7 CECT 4076 (1, 10 y $\left.10^{5} \mathrm{ufc} / \mathrm{ml}\right)$. Posteriormente se sometieron al enriquecimiento mencionado y en cada muestra se investigó la presencia de Stx1 y Stx2. Paralelamente, se investigó la presencia de las toxinas en muestras de leche de tanque de 130 explotaciones pertenecientes al CPO.

\section{DETECCIÓN DE LOS GENES stx1 y stx2 EN LOS ENRIQUECIMIENTOS}

Tanto con las muestras correspondientes al enriquecimiento de leche de tanque como en aquellas procedentes del aire, el agua, el pienso y las heces se llevó a cabo una 
técnica de PCR para la detección de los genes que codifican para las toxinas Shiga. Para ello se tomaba $1 \mathrm{ml}$ de cada uno de los enriquecimientos y se centrifugaba (13.000 g durante 3 minutos) para obtener un "pellet" o sedimento. A continuación éste se resuspendía en Phosphate buffered saline (PBS, Oxoid) y se volvía a centrifugar descartando el sobrenadante. Este lavado se hacía dos veces, y finalmente se resuspendía el "pellet" resultante en una solución acuosa que, en el caso de los enriquecimientos de la leche, contenía Tritón X-100 (Sigma-Aldrich Química, S.A., Madrid, España) al 1\% y Chelex ${ }^{\circledR} 100$ Resin (Bio-Rad Laboratories, Hercules, CA, USA) al 2\%. El Tritón actúa como detergente y el Chelex ${ }^{\circledR}$ como quelante de los iones de calcio presentes en la leche. Para la extracción del ADN las muestras se sometieron a un tratamiento de $100^{\circ} \mathrm{C}$ durante 15 minutos.

Finalmente se realizó una PCR múltiple para detectar los genes stx1 y stx2 utilizando los cebadores a una concentración de 250 nM (Paton \& Paton, 1998b) (Tabla I.1). La amplificación de estos genes se realizó en un termociclador Eppendorf Mastercycler ${ }^{\circledR}$ Gradient (Eppendorf, Hamburgo, Alemania) con las condiciones que se detallan a continuación y se muestran en la Figura I.1. Se realizó una desnaturalización inicial a 94ํㄷ durante 3 minutos seguida de 30 ciclos compuestos por, una desnaturalización a 92ㅇ durante 30 segundos, una hibridación a 61 ํㅡ durante 30 segundos y una elongación a 72으 durante 1 minuto, para terminar con una elongación final a 72ํC durante 1,5 minutos.

El producto de la PCR fue sometido a una electroforesis en un gel de agarosa (Laboratorios Conda, Madrid, España) al 1,5\% en Tris-Acetic Acid-EDTA (TAE, Laboratorios Conda) y posteriormente para su revelado se sumergió en una solución con $10 \mathrm{mg} / \mathrm{ml}$ de bromuro de etidio (Sigma-Aldrich Química) y se observaron los resultados exponiendo el gel a la luz ultravioleta en un transiluminador (Bio-Rad Laboratories). Se fotografió el gel empleando el sistema de documentación de geles Digimage System acoplado a una cámara digital Canon Power Shot G11. 
Tabla I.1. Cebadores utilizados en la técnica de PCR múltiple para la detección de los genes stx 1 y stx 2 en los enriquecimientos de las muestras.

\begin{tabular}{|c|c|c|c|c|}
\hline Diana & Cebador & Secuencia $\left(5^{\prime} \rightarrow 3^{\prime}\right)$ & $\begin{array}{c}\text { Tamaño } \\
(\mathrm{pb})^{\mathrm{a}}\end{array}$ & Referencia \\
\hline \multirow{2}{*}{$s t x 1$} & Stx1F & ATAAATTGCCATTCGTTGACTAC & 180 & \multirow{4}{*}{$\begin{array}{l}\text { (Paton \& Paton, } \\
\text { 1998b) }\end{array}$} \\
\hline & Stx1R & AGAACGCCCACTGAGATCATC & 180 & \\
\hline \multirow{2}{*}{ stx 2} & Stx2F & GGCACTGTCTGAAACTGCTCC & \multirow{2}{*}{255} & \\
\hline & Stx2R & TCGCCAGTTATCTGACATTCTG & & \\
\hline
\end{tabular}

a pb: Pares de bases

\section{OBTENCIÓN DE AISLADOS DE ORIGEN OVINO}

Se obtuvieron aislados procedentes de leche de tanque, aire, agua, pienso y heces en explotaciones del CPO. Para ello, y teniendo en cuenta que la PCR no tiene un $100 \%$ de fiabilidad, se sembraron todos los enriquecimientos (tanto los que resultaron positivos para los genes que codifican para las toxinas Shiga como los que resultaron negativos) en dos medios diferentes.

- CT-SMAC (Sorbitol MacConkey Agar suplementado con Cefixima y Telurito, Oxoid). Esta bacteria normalmente no fermenta el sorbitol, por lo que produce colonias incoloras, mientras que otras $E$. coli no-0157:H7 generalmente si fermentan el sorbitol, por lo que darán lugar a colonias de color rosa. Se observaron estas placas tras su incubación a $37^{\circ} \mathrm{C}$ durante 24 horas.

○ "Enterohaemolysin Agar" (Beutin et al., 1989): Las placas se examinaron tras incubar a $37{ }^{\circ} \mathrm{C}$ durante 4 horas y después de transcurridas otras 20 horas. Cuando aparece hemólisis a las 4 horas de incubación se trata de una $\alpha$ hemolisina, y si la hemólisis aparece tras 24 horas de incubación se trata de una enterohemolisina. Por tanto se aislaron las colonias que presentaban hemólisis únicamente tras 24 horas de incubación. Estas se inocularon en CTSMAC para comprobar que mostraban la morfología característica de $E$. coli en este medio. 
Las colonias obtenidas en estos medios se sometieron a pruebas de PCR buscando los genes que codifican para las toxinas Shiga (stx1 y stx2) y el gen que codifica para la intimina (eae) (Paton \& Paton, 1998b) (Tabla I.2).

Tabla I.2. Cebadores utilizados en la técnica de PCR múltiple para la detección de los genes stx1, stx2 y eae en las cepas aisladas.

\begin{tabular}{|c|c|c|c|c|}
\hline Diana & Cebador & Secuencia $\left(5^{\prime} \rightarrow 3^{\prime}\right)$ & $\begin{array}{l}\text { Tamaño } \\
(\mathrm{pb})^{\mathrm{a}}\end{array}$ & Referencia \\
\hline \multirow{2}{*}{ stx1 } & Stx1F & ATAAATTGCCATTCGTTGACTAC & \multirow{2}{*}{180} & \multirow{6}{*}{$\begin{array}{l}\text { (Paton \& Paton, } \\
\text { 1998b) }\end{array}$} \\
\hline & Stx1R & AGAACGCCCACTGAGATCATC & & \\
\hline \multirow{2}{*}{ stx2 } & Stx2F & GGCACTGTCTGAAACTGCTCC & \multirow{2}{*}{255} & \\
\hline & Stx2R & TCGCCAGTTATCTGACATTCTG & & \\
\hline \multirow{2}{*}{ eae } & eaeF & GACCCGGCACAAGCATAA & \multirow{2}{*}{384} & \\
\hline & eaeR & CCACCTGCAGCAACAAGAGG & & \\
\hline
\end{tabular}

a pb: Pares de bases

Los aislados que presentan uno o los dos genes que codifican para las toxinas Shiga se incluyeron en el grupo de E. coli productores de toxina Shiga (STEC) con o sin la presencia del gen eae, mientras que los que sólo presentaban el gen que codifica para la intimina, se consideraron E. coli enteropatogénicos (EPEC).

La amplificación de estos genes se realizó en un termociclador Eppendorf

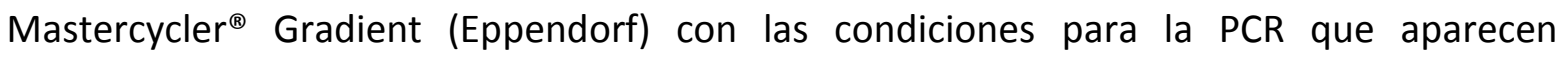
detalladas en la Figura I.1. Se reveló el producto de PCR tal y como se ha descrito anteriormente.

Los aislados positivos para uno o varios genes se sembraron en TSA (Oxoid) incubando las placas a $37{ }^{\circ} \mathrm{C}$ durante 24 horas. Posteriormente, se recogió cantidad suficiente de crecimiento y se guardó a -40 ㅇ e en Nutrient Broth (NB, Oxoid) con un $40 \%$ de Glicerol (Acofarma, Barcelona, España) para su posterior caracterización. 


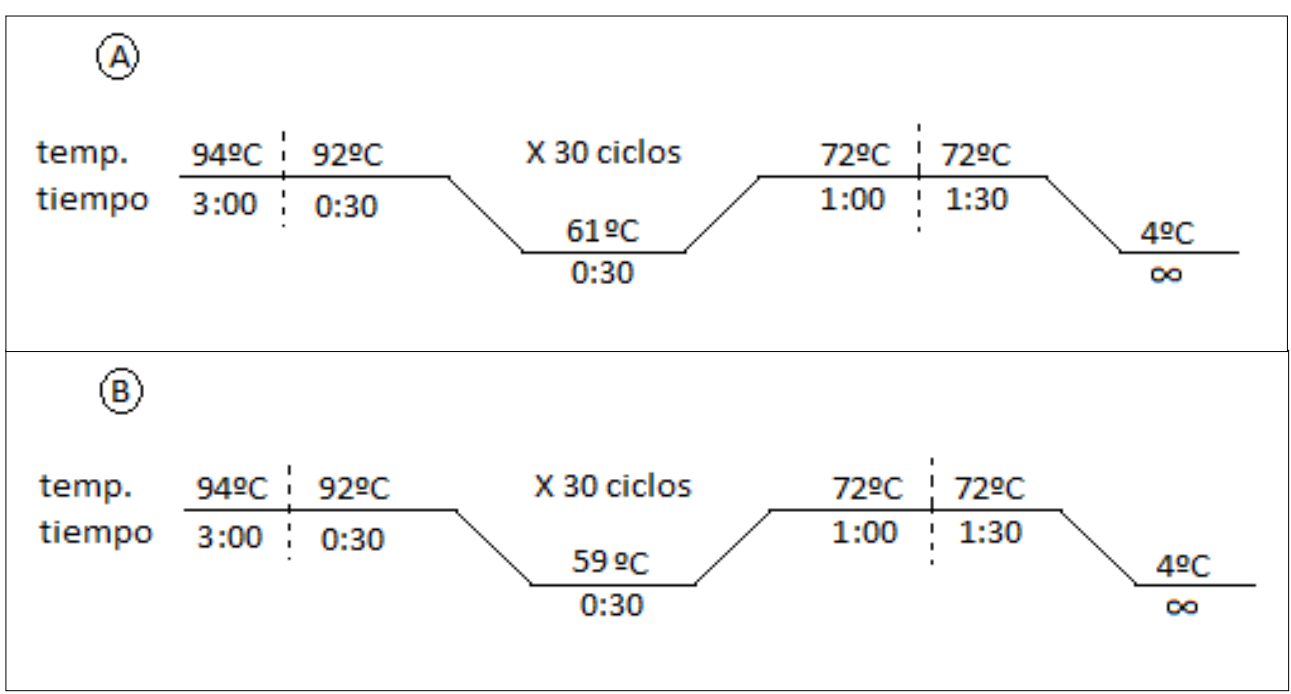

Genes stx1 y stx2 (A). Gen eae (B).

Figura I.1. Condiciones de la PCR para la amplificación de los genes presentes en los aislados. 


\section{RESULTADOS}

\section{DETECCIÓN DE TOXINAS Stx1 Y Stx2 EN LECHE DE OVEJA}

En las pruebas control realizadas con el test inmunológico ProSpecT ${ }^{\circledR}$ Shiga Toxin (STEC) Microplate Assay en leche inoculada con la cepa de colección (CECT 4076) se obtuvieron resultados diferentes en función de si la leche había recibido o no un tratamiento de pasterización y de los niveles a los que se inoculó la cepa.

Tras el enriquecimiento, en las muestras de leche de oveja pasterizada inoculadas con 1,10 y $10^{5} \mathrm{ufc} / \mathrm{ml}$ de la cepa de colección, el test inmunológico dio un resultado positivo para las toxinas Shiga en todos los casos (Figura I.2). Sin embargo, en muestras de leche cruda inoculada y sometida al mismo enriquecimiento, el test solo detectó las toxinas Shiga cuando la concentración inicial de la cepa STEC en la muestra era del orden de $10^{5}$ ufc/ml (Tabla I. 3).

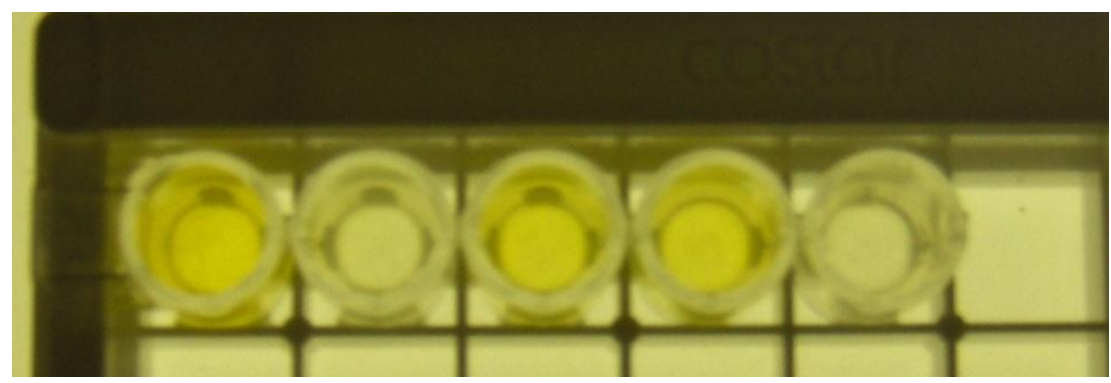

Figura I.2. Prueba del test inmunológico en muestras de leche pasterizada inoculada con una cepa de colección (E. coli CECT 4076). De izquierda a derecha: positivo del test, negativo del test, leche pasterizada inoculada con $10 \mathrm{ufc} / \mathrm{ml}$, leche pasterizada inoculada con $1 \mathrm{ufc} / \mathrm{ml}$ y leche sin inocular.

Tabla I.3. Medidas de absorbancia (D.O.) $)^{a}$ obtenidas tras la utilización del test inmunológico en leche cruda de oveja inoculada con la cepa de colección E. coli CECT 4076.

\begin{tabular}{|c|c|c|c|c|c|c|}
\hline \multirow{2}{*}{$\lambda$} & \multirow{2}{*}{ Control + } & \multirow{2}{*}{ Control - } & \multirow{2}{*}{$\begin{array}{l}\text { Leche sin } \\
\text { inocular }\end{array}$} & \multicolumn{3}{|c|}{ Leche inoculada } \\
\hline & & & & $10^{5} \mathrm{ufc} / \mathrm{ml}$ & $10 \mathrm{ufc} / \mathrm{ml}$ & $1 \mathrm{ufc} / \mathrm{ml}$ \\
\hline $450 n m^{b}$ & 2,124 & 0,065 & 0,058 & 1,234 & 0,063 & 0,064 \\
\hline
\end{tabular}


Ni la toxina Stx1 ni la Stx2 se detectaron en las 130 muestras de leche de tanque analizadas.

\section{DETECCIÓN DE LOS GENES stx1 Y stx2 EN LOS ENRIQUECIMIENTOS}

De un total de 388 muestras de leche de tanque de otras tantas explotaciones, un 45,4\% (176) resultó positivo para uno o los dos genes que codifican para las toxinas Shiga (Tabla 1.4 y Figura I.3).

Tabla I.4. Incidencia de los genes stx1 y stx2 en muestras de leche de tanque de 388 explotaciones.

\begin{tabular}{|c|c|c|c|c|}
\hline \multirow{2}{*}{$\begin{array}{c}\text { № de } \\
\text { muestras }\end{array}$} & \multirow{2}{*}{ Positivas stxs } & \multicolumn{3}{|c|}{ Genotipo } \\
\hline & & stx1+ & stx2+ & stx $1+/ s t \times 2+$ \\
\hline 388 & $176(45,4 \%)$ & $35(9 \%)$ & $39(10,1 \%)$ & $102(26,3 \%)$ \\
\hline
\end{tabular}

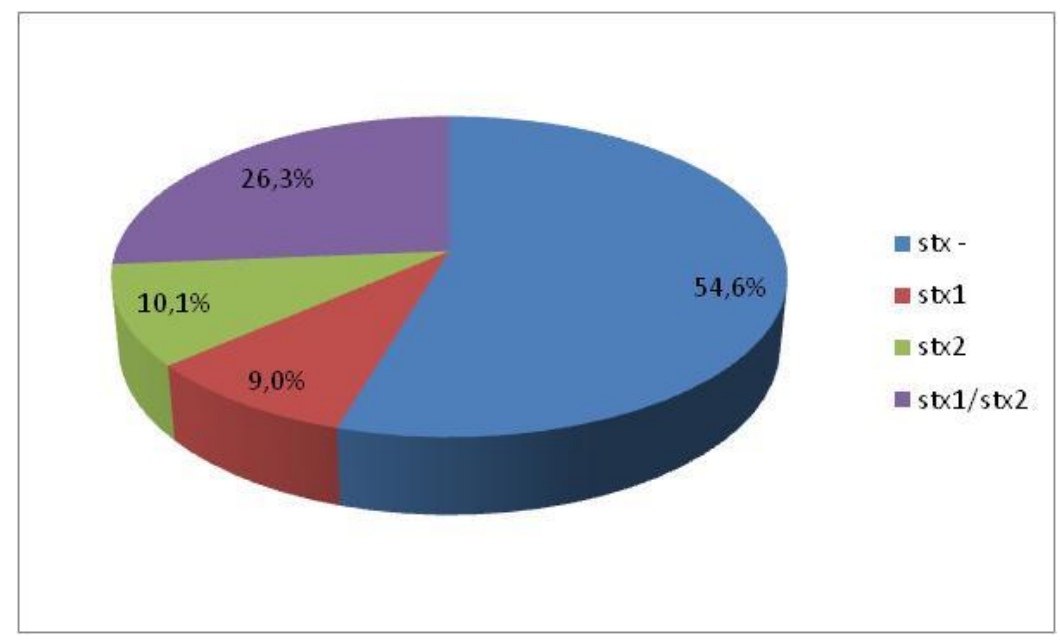

Figura I.3. Distribución de las 388 muestras de leche de tanque en función de la presencia de los genes stxs.

En las diez explotaciones en las que se realizaron muestreos de aire, agua, pienso y heces de ovino durante dos estaciones (primavera y verano) se detectaron genes stxs sólo en muestras procedentes de agua y de heces. Nueve (45\%) de las 20 muestras de agua resultaron positivas para los genes stxs; ocho de ellas (40\%) para el gen stx2 y una (5\%) para ambos genes (stx1 y stx2). Cinco (25\%) muestras de heces resultaron positivas para stx2. Estos datos se presentan en la Tabla I.5. 
Tabla I.5. Incidencia de los genes stx1 y stx2 en muestras de agua y en heces de ovino.

\begin{tabular}{|c|c|c|c|c|c|c|}
\hline \multirow{2}{*}{ Estación } & \multirow{2}{*}{$\begin{array}{l}\text { Tipo de } \\
\text { muestra }\end{array}$} & \multirow{2}{*}{$\begin{array}{c}\text { № de } \\
\text { muestras }\end{array}$} & \multirow{2}{*}{ Positivas stxs } & \multicolumn{3}{|c|}{ Genotipo } \\
\hline & & & & stx1+ & stx2+ & st $\times 1+/ s t \times 2+$ \\
\hline \multirow{2}{*}{ Primavera } & Agua & 10 & $4(40 \%)$ & 0 & $3(30 \%)$ & $1(10 \%)$ \\
\hline & Heces & 10 & $2(20 \%)$ & 0 & $2(20 \%)$ & 0 \\
\hline \multirow{2}{*}{ Verano } & Agua & 10 & $5(50 \%)$ & 0 & $5(50 \%)$ & 0 \\
\hline & Heces & 10 & $3(30 \%)$ & 0 & $3(30 \%)$ & 0 \\
\hline
\end{tabular}

\section{OBTENCIÓN DE AISLADOS DE ORIGEN OVINO}

El número total de cepas STEC y EPEC aisladas fue de 134. De las 388 muestras de leche de tanque se obtuvieron 112 cepas. De ellas, 50 presentaban uno o los dos genes stxs, con o sin la presencia del gen eae, por lo que fueron clasificadas como STEC. De las muestras de leche de tanque, se obtuvieron también un total de 62 cepas que poseían el gen eae sin presentar ninguno de los genes stxs, es decir cepas EPEC. Siguiendo el mismo criterio; de las heces, se aislaron 10 cepas del grupo STEC y cuatro del EPEC. Del agua, dos STEC y cinco EPEC y del aire, sólo una EPEC. En las muestras de pienso no se detectaron cepas STEC ni EPEC. Estos datos y los genotipos hallados se presentan en la Tabla I.6 y en la Figura I.4.

Tabla I.6. Incidencia de los diferentes genotipos en las 134 cepas de origen ovino aisladas de leche, heces, agua y aire.

\begin{tabular}{|c|c|c|c|c|c|c|}
\hline \multirow{2}{*}{ Origen } & \multirow{2}{*}{$\begin{array}{l}\text { Número } \\
\text { de cepas }\end{array}$} & \multicolumn{4}{|c|}{ STEC } & \multirow{2}{*}{$\begin{array}{l}\text { EPEC } \\
\text { eae+ }\end{array}$} \\
\hline & & stx $1+$ & $s t \times 1+/ s t \times 2+$ & stx $1+/ e a e+$ & stx $2+/ e a e+$ & \\
\hline Leche & 112 & $35(31,2 \%)$ & $10(8,9 \%)$ & $2(1,8 \%)$ & $3(2,7 \%)$ & $62(55,4 \%)$ \\
\hline Heces & 14 & $9(64,3 \%)$ & $1(7,1 \%)$ & 0 & 0 & $4(28,6 \%)$ \\
\hline Agua & 7 & $1(14,3 \%)$ & 0 & 0 & $1(14,3 \%)$ & $5(71,4 \%)$ \\
\hline Aire & 1 & 0 & 0 & 0 & 0 & $1(100 \%)$ \\
\hline Total & 134 & $45(33,6 \%)$ & $11(8,2 \%)$ & $2(1,5 \%)$ & $4(3 \%)$ & $72(53,7 \%)$ \\
\hline
\end{tabular}

Considerando todas las explotaciones y todas las muestras analizadas tanto de leche como de agua, heces, aire y pienso, se obtuvieron aislados de STEC en 34 explotaciones $(8,8 \%)$ y de EPEC en 55 explotaciones $(14,2 \%)$. Cinco cepas STEC fueron aisladas de muestras de leche de cuatro explotaciones en las que el enriquecimiento había resultado negativo a la presencia de los genes stxs. En el caso de las muestras ambientales 
(aire, agua, heces y pienso), se aislaron 22 cepas (11 en primavera y 11 en verano). De ellas, 12 (54,5\%) (obtenidas la mitad en primavera y la mitad en verano) poseían uno o los dos genes stxs y $10(45,5 \%)$ (obtenidas la mitad en primavera y la mitad en verano) poseían únicamente el gen eae. En una explotación se obtuvieron aislamientos STEC en muestras de agua y heces en el muestreo de verano, y tres explotaciones resultaron positivas para el aislamiento de STEC en heces en ambos muestreos (primavera y verano). Por otro lado, en una explotación en el muestreo de verano y en dos en el de primavera, se obtuvieron aislamientos EPEC en muestras de agua y heces. Además se obtuvieron aislamientos en heces y aire en una misma explotación en el muestreo de verano. Una explotación resultó positiva para el aislamiento de EPEC en agua en ambos muestreos (primavera y verano).

La Figura I.4A presenta la distribución de todas las cepas aisladas (STEC y EPEC) en función de su origen y en la Figura I.4B se muestra la distribución de los genotipos de todas las cepas aisladas (STEC y EPEC).

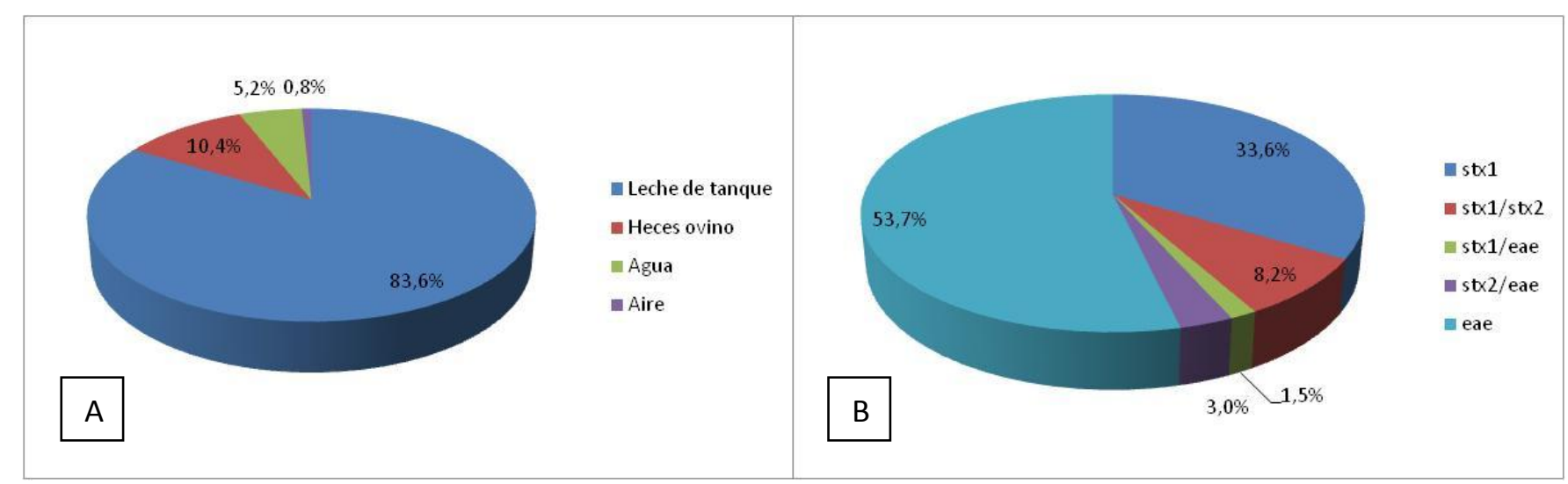

Figura I.4. Distribución de todas las cepas aisladas (STEC y EPEC) en función de su origen (A) y de sus genotipos (B).

Finalmente, la Tabla 1.7 presenta las notas de auditoría durante los años 2009 y 2010 de algunas de las explotaciones en las que se aislaron cepas STEC tanto de leche como del medio ambiente (Otero, 2013). Para el cálculo de estas notas en las auditorías se valoraron diferentes aspectos (nota sobre una escala de 100), al área crítica de Sanidad animal le corresponde un $30 \%$ de la nota final, a la de Higiene del ordeño también un 30\%, y a las cuatro restantes (Agua y alimentación, Bienestar animal, Medio ambiente, y Formación y registro) un $10 \%$ a cada una. 


\section{DISCUSIÓN}

\section{DETECCIÓN DE TOXINAS Stx1 Y Stx2 EN LECHE DE OVEJA}

Los ensayos inmunoenzimáticos (EIA) para la detección de toxinas Stxs son de gran utilidad en muestras clínicas ya que permiten detectar su presencia y posteriormente confirmar la de cepas STEC en heces de pacientes, bien directamente o tras un periodo de enriquecimiento (Gavin et al., 2004). Entre estos EIA destacan tres: el sistema Premier EHEC test (Meridian Bioscience, Inc., Cincinnati, OH, USA), el sistema Duopath ${ }^{\circledR}$ Verotoxins Gold Labelled Immuno Sorbent Assay (GLISA) (Merck, Alemania) y el sistema utilizado en este trabajo (ProSpecT ${ }^{\circledR}$ Shiga Toxin (STEC) Microplate Assay). Acheson et al. (1996) estudiaron la eficacia del primero de estos métodos EIA en leche y carne picada de vacuno sometidos a un enriquecimiento previo, concluyendo que, en ambos alimentos, tanto inoculados como sin inocular, permitía detectar toxinas asociadas a la presencia inicial de niveles muy bajos de células pertenecientes a diversos serogrupos de STEC.

El Ministerio de Sanidad de Canadá ("Health Canada") que es responsable del control de la inocuidad de los alimentos y del etiquetado relativo a la inocuidad y a los aspectos nutricionales de los mismos ("Food \& Nutrition") contempla la utilización de los sistemas Premier EHEC test y Duopath para la detección de Stxs en alimentos y/o sus ingredientes con el fin de comprobar si cumplen los requisitos legales recogidos en la Ley sobre Productos Alimenticios y Farmacéuticos ("Food and Drug Acts") ("Health Canada Laboratory procedure MFLP-83 y Health Canada Laboratory procedure MFLP-93") (disponibles en http://www.hc-sc.gc.ca/fn-an/res-rech/analy-meth/microbio/volume3eng.php, última visita 28 de Marzo de 2014).

La sensibilidad y especificidad del método empleado por nosotros (ProSpecT ${ }^{\circledR}$ Shiga Toxin (STEC) Microplate Assay) han sido investigadas en heces de pacientes (Gavin et al., 2004), observándose una sensibilidad y especificidad del 100\% para la detección de E. coli 0157 y del 93\% para la presencia de cepas 0157 y no-O157 pero, hasta ahora, su utilidad para muestras de alimentos no había sido investigada.

En este estudio, en las muestras de leche pasterizada y posteriormente inoculada con diferentes niveles de la cepa CECT 4076, el resultado con el método ProSpecT ${ }^{\circledR}$ fue 
siempre positivo, mientras que para la leche cruda, solo se obtuvieron resultados positivos cuando se inocularon niveles altos de la cepa CECT 4076 (10 $\left.10^{5} \mathrm{ufc} / \mathrm{ml}\right)$. Además, ninguna de las muestras de leche de tanque sometidas a esta prueba resultó positiva. Estos datos sugieren que la flora propia de la leche influye en la producción de Stxs por parte de STEC. Otros microorganismos y quizás algunos compuestos antimicrobianos (termolábiles) naturalmente presentes en la leche de oveja podrían haber inhibido el crecimiento de la cepa STEC y/o la producción de estas toxinas. Por tanto, no parece que el método ProSpect ${ }^{\circledR}$ sea útil para la detección de las toxinas Stxs en leche de oveja.

Willford et al. (2009) compararon tres métodos EIA: sistemas ProSpecT ${ }^{\circledR}$, Premier EHEC test y Ridascreen Verotoxin Enzyme Immunoassay ( $r$-Biopharm AG, Darmstadt, Alemania). Todos fueron capaces de detectar la presencia de Stxs en 67 de las 70 muestras de cultivos puros de cepas de $E$. coli que presentaban uno o más de los genes que codifican para estas toxinas. Los autores sugirieron que la no detección de Stxs en tres muestras inoculadas podría deberse a la presencia de subtipos de Stxs que estos EIA no pueden detectar (Stx2d y Stx2e en los tres sistemas y, además, Stx1d en el caso del sistema Ridascreen). De hecho existe otro estudio (Feng et al., 2011) en el que se amplían los subtipos de estas toxinas que el ProSpecT ${ }^{\circledR}$ no puede detectar (Stx1c, Stx2b, Stx2c, Stx2e, Stx2f y Stx2g), aunque estos autores concluyen que estos datos deben tomarse con precaución, ya que varían de una cepa a otra debido a la escasa o nula expresión de toxinas Stxs, por lo que los EIA deberían combinarse con otros métodos. Por otra parte, hay que señalar que el método ProSpecT ${ }^{\circledR}$ detectó como positiva una de las muestras control que no contenía ninguno de los genes que codifican para las toxinas Shiga. Los tres sistemas EIA necesitaban niveles altos de células de STEC para poder detectar las toxinas; así, los métodos ProSpec ${ }^{\circledR}$ y Premier EHEC las detectaban cuando éstos eran de $10^{6} \mathrm{ufc} / \mathrm{ml}$ y para el método Ridascreen era preciso $10^{7} \mathrm{ufc} / \mathrm{ml}$. En leche y otros alimentos no se encuentran concentraciones elevadas de STEC pero estos mismos autores (Willford et al., 2009) han demostrado, en medios de cultivo, que utilizando técnicas de enriquecimiento, los niveles iniciales bajos alcanzan, al llegar la fase estacionaria la concentración de células necesaria para que en el medio se encuentren niveles detectables de toxinas Stxs. Un hallazgo interesante del trabajo de Willford et al. (2009) es el hecho de que al utilizar uno de estos sistemas (Premier EHEC test) para detectar Stxs en heces de bovino inoculadas, la 
sensibilidad disminuyó, al menos diez veces. Este hecho, probablemente debido a las propias heces y su flora, podría, al menos en parte, explicar el comportamiento de nuestras cepas en leche cruda.

Por tanto, la no detección de las toxinas Stxs en nuestras muestras de leche pudo deberse a diversos factores. En primer lugar la propia cepa puede poseer los genes que codifican para las toxinas Stxs y no producirlas, por otro lado puede que las toxinas Stxs se encuentren en el medio pero pertenezcan a un subtipo no detectado por el test. Finalmente la leche y su flora podrían inhibir la producción de toxinas por parte de las cepas STEC y tampoco se detectarían.

\section{DETECCIÓN DE LOS GENES stx1 Y stx2 Y OBTENCIÓN DE AISLADOS EN LOS ENRIQUECIMIENTOS DE ORIGEN OVINO}

En este estudio, un elevado porcentaje de las muestras de leche $(45,4 \%)$ resultaron positivas a uno o los dos genes que codifican para las toxinas Shiga. En estudios previos dedicados a la determinación cualitativa (PCR) de genes de STEC en leche de pequeños rumiantes se obtuvieron porcentajes notablemente inferiores. Así, en Suiza, Muehlherr et al. (2003) encontraron que las muestras stxs positivas para leche de tanque tanto de oveja como de cabra fueron del 23,8 y $23 \%$, respectivamente y D'Amico et al. (2008), en los Estados Unidos de América (USA) no encontraron muestras positivas en leche de oveja y sólo un $0,75 \%$ en leche de cabra. El análisis de los datos publicados debe de hacerse teniendo en cuenta aspectos tales como las diferencias en el método de muestreo, los métodos analíticos utilizados, las especies animales e incluso las épocas de muestreo. Hay que considerar que en la mayoría de los estudios sólo se investiga la presencia de $E$. coli O157 y que son escasos aquellos dedicados a la búsqueda de otros serogrupos (Farrokh et al., 2013).

Entre las muestras ambientales, el porcentaje de muestras positivas de genes que codifican para las Stxs en los enriquecimientos de heces de 10 explotaciones fue del $20 \%$ en primavera y del $30 \%$ en verano. En los enriquecimientos de agua de bebida de esas mismas explotaciones, la incidencia de muestras stxs positivas fue del $40 \%$ en primavera y $50 \%$ en verano. Como ya se ha indicado, en las muestras de aire y pienso no se detectaron stxs. Es preciso recordar que las muestras ambientales (heces, agua, pienso y aire) se 
tomaron, en primavera y verano, en 10 explotaciones en las que la leche de tanque había sido positiva para STEC. No existe información acerca de la presencia de stxs en heces de ovino aunque si existe acerca de la incidencia de STEC en rebaños. Así, Blanco et al. (2003) estudiaron, en Extremadura, muestras rectales de ovejas de 93 explotaciones, encontrando animales portadores en el $68 \%$ de ellas. Este porcentaje contrasta con lo encontrado en nuestro estudio, en el que únicamente el $25 \%$ de las muestras de heces de las explotaciones muestreadas resultaron positivas para alguno de los genes stxs. Esta diferencia puede deberse al método de muestreo utilizado (muestras rectales frente al uso de calcetines para toma de muestras de heces del suelo).

El agua de bebida, al igual que las heces de animales infectados, también puede transmitir STEC en el rebaño, probablemente debido a la contaminación con heces de forma directa o indirecta, pudiendo actuar como reservorio de este microorganismo y vehículo de infección para los animales (LeJeune et al., 2001; Berry \& Wells, 2010). Los piensos, antes de la exposición a los animales, no se consideran un vehículo de transmisión de STEC, aunque puede darse contaminación durante la alimentación (Berry \& Wells, 2010). En nuestro estudio las muestras de pienso se tomaron antes de su distribución en los comederos, lo que explica que no se detectaran genes stxs. Además parece que el aire no es un vehículo adecuado para la transmisión de STEC en las explotaciones de ovino.

Las muestras de leche de 34 explotaciones resultaron positivas para el aislamiento de cepas STEC, obteniendo un total de 50 aislados. La tasa de aislamiento $(8,8 \%$ de las muestras de leche de tanque) fue superior a la mayoría de los hallados en trabajos previos en los que oscilaban entre 1 y 8,3\% (Dontorou et al., 2003; Muehlherr et al., 2003; Caro et al., 2006; Rey et al., 2006; D'Amico et al., 2008; Solomakos et al., 2009; Martin \& Beutin, 2011). Únicamente, en un estudio realizado también en Castilla y León con muestras de leche almacenada en fábrica (Caro et al., 2011), se encontró una incidencia mayor a la obtenida por nosotros ya que de un total de 159 muestras de leche, se aislaron cepas STEC pertenecientes a tres serotipos diferentes, siendo su incidencia: 0157 (18,2\%), 011 (8,2\%) y $026(5,7 \%)$. Los valores obtenidos en este estudio muestran mayores tasas de prevalencia y aislamiento de STEC en leche de oveja, lo que podría estar relacionado con el procedimiento de enriquecimiento empleado, sin ningún antibiótico y con una temperatura de $42^{\circ} \mathrm{C}$. Algunos de los estudios realizados en leche de ovino utilizaban 
enriquecimientos suplementados con novobiocina y una temperatura de $37^{\circ} \mathrm{C}$, lo que se ha visto que inhibe a algunas cepas STEC (Vimont et al., 2006).

El aislamiento de cinco cepas STEC de muestras de leche de cuatro explotaciones en las que el enriquecimiento había resultado negativo a la presencia de los genes stxs puede explicarse por la sensibilidad de la PCR. Esta sensibilidad se ha visto aumentada en gran medida en muestras de heces y alimento al realizar un enriquecimiento previo de estas muestras. Con el enriquecimiento se consigue por un lado diluir los inhibidores que pudieran estar presentes en la muestra, y por otro aumentar el número de copias de la secuencia diana al aumentar el crecimiento bacteriano, quizás en estos casos el enriquecimiento de la muestra no fue suficiente (Paton \& Paton, 1998a).

En el caso de EPEC, se aislaron cepas en 55 explotaciones (14,2\% de las muestras de leche de tanque), obteniéndose un total de 62 aislados. No hemos encontrado publicaciones relativas a la prevalencia de este tipo patógeno de $E$. coli en leche de oveja, aunque sí en quesos elaborados con leche cruda de oveja así como en leche de otras especies. En un trabajo realizado con quesos de oveja, se aislaron 95 cepas de E. coli de las cuales el 3,09\% fue adscrito a EPEC (Holko et al., 2006). Los porcentajes encontrados en leche de otras especies (yak, cabra y vaca) son inferiores a los hallados por nosotros, oscilando entre el 0 y el 7,7\% (Silva et al., 2001; Cortés et al., 2005; Bandyopadhyay et al., 2012).

Por lo que respecta a STEC en las muestras ambientales, sólo se aislaron cepas de este tipo en algunas de las explotaciones muestreadas; a pesar de que la leche de tanque de todas ellas contenía cepas STEC. Las 12 cepas aisladas procedían mayoritariamente de heces (10) y, en menor medida de agua (2). Nuestros resultados indican que, como en heces humanas, la presencia de stxs en heces de ovino tiene una mayor correlación con el aislamiento de STEC. Aunque el sistema EIA utilizado podría ser útil para detectar explotaciones positivas de STEC, su aplicación práctica es inviable dado el elevado coste de la prueba.

Al comparar los aislamientos de cepas STEC obtenidas de heces según la estación de muestreo, se observó que no existían diferencias ya que la mitad se obtuvo en primavera y la otra mitad en verano. Tampoco Sánchez et al. (2010a) observaron variaciones 
estacionales en el aislamiento de cepas STEC a partir de heces de ovino. Respecto a la incidencia de aislamientos en leche a lo largo del año se obtuvieron un mayor número de aislados en los meses de invierno (datos no mostrados), sin embargo no se puede concluir que exista una mayor incidencia en invierno por las características del muestreo (la toma de muestras de leche de tanque no fue homogénea a lo largo del año, se tomaron diferente número de muestras en las distintas estaciones en función de la disponibilidad). Los brotes y casos de infecciones alimentarias humanas producidos por STEC y que fueron declarados durante el año 2010 en la UE (EFSA, 2012) mostraban una mayor incidencia en verano y otoño probablemente debido a que las condiciones climatológicas favorecen la supervivencia de la bacteria en el medio ambiente. Las diez cepas de EPEC (cuatro de heces, cinco de agua y una de aire) que se aislaron en cinco de las 10 explotaciones muestreadas, se obtuvieron, como en el caso de STEC, la mitad en primavera y la mitad en verano.

La Tabla I.7 proporciona información acerca de las condiciones higiénico-sanitarias de parte de las explotaciones en las que se aislaron cepas STEC a partir de muestras de leche y/o ambientales. Esto se refleja en las notas obtenidas en las auditorías realizadas durante los años 2009 y 2010 para su certificación. Se observa que no existe una relación directa entre la nota de seguridad alimentaria de la explotación y la presencia de STEC, ya que se aislaron estas cepas tanto en rebaños con notas máximas (buenas prácticas ganaderas e higiene en la producción) como en rebaños con seguridad comprometida por causas como elevados recuentos bacteriológicos o presencia de inhibidores en la leche (antibióticos). Esto podría ser debido, por un lado, a que los rumiantes domésticos son reservorio de STEC (Farrokh et al., 2013) pudiendo, por tanto, aparecer en el rebaño sin relación aparente con el manejo y, por otro, a que pueden existir fuentes de contaminación externas a la granja. En relación con la segunda posibilidad, algunos trabajos señalan que han aislado cepas STEC semejantes (PFGE) a las obtenidas de rumiantes domésticos y de varias especies de animales silvestres (Sánchez et al., 2010b; Sánchez et al., 2010c; Díaz et al., 2011; Hofer et al., 2012), que también son reservorios de STEC y que pueden ser origen de estas cepas para las ovejas ya que comparten zonas de pasto y abrevaderos.

En resumen, el sistema de enzimoinmunoensayo de microplaca en fase sólida (Prospect ${ }^{\circledR}$ Shiga Toxin) no es útil para la detección de Stxs en leche de oveja. La incidencia 
de genes stxs en las explotaciones pertenecientes al CPO fue muy elevada aunque el aislamiento de cepas STEC fue considerablemente inferior. También es destacable el número de explotaciones en las que se detectaron cepas de EPEC tanto en leche como en muestras ambientales. En cualquier caso, resulta evidente que la leche de oveja y la propia explotación son una fuente significativa de cepas de estos dos tipos de $E$. coli patógenos para el hombre que podrían estar presentes en quesos elaborados con leche cruda y, por tanto, suponer un riesgo para la salud humana. 


\section{BIBLIOGRAFÍA}

1. Acheson, D. W. K., Lincicome, L. L., De Breucker, S. and Keusch, G. T. 1996. Detection of Shiga-like toxin-producing Escherichia coli in ground beef and milk by commercial enzyme immunoassay. J. Food Prot., 59: 344-349.

2. Aidar-Ugrinovich, L., Blanco, J., Blanco, M., Blanco, J., Leomil, L., Dahbi, G., Mora, A., Onuma, D., Silveira, W. and Pestana, d. C. A. 2007. Serotypes, virulence genes, and intimin types of Shiga toxin-producing Escherichia coli (STEC) and enteropathogenic $E$. coli (EPEC) isolated from calves in Sao Paulo, Brazil. Int. J. Food Microbiol., 115: 297.

3. Almeida, P. M., Arais, L., Andrade, J., Prado, E. H., Irino, K. and Cerqueira, A. 2012. Characterization of atypical Enteropathogenic Escherichia coli (aEPEC) isolated from dogs. Vet. Microbiol., 158: 420-424.

4. Anónimo. 2012. ISO/TS 13136:2012. Microbiology of food and animal feed -- Realtime polymerase chain reaction (PCR)-based method for the detection of food-borne pathogens -- Horizontal method for the detection of Shiga toxin-producing Escherichia coli (STEC) and the determination of $\mathrm{O} 157,0111, \mathrm{O} 26,0103$ and 0145 serogroups. International Organization for Standardization. Ginebra.

5. Anónimo. 2001. UNE-EN ISO 16654:2001. Microbiología de los alimentos para consumo humano y animal. Método horizontal para la detección de Escherichia coli 0157. Asociación Española de Normalización y Certificación. Madrid. 
Capítulo I. Bibliografía

6. Araujo, V., Pagliares, V., Queiroz, M. and Freitas-Almeida, A. 2002. Occurrence of Staphylococcus and enteropathogens in soft cheese commercialized in the city of Rio de Janeiro, Brazil. J. Appl. Microbiol., 92: 1172-1177.

7. Bandyopadhyay, S., Lodh, C., Rahaman, H., Bhattacharya, D., Bera, A., Ahmed, F., Mahanti, A., Samanta, I., Mondal, D. and Sarkar, S. 2012. Characterization of shiga toxin producing (STEC) and enteropathogenic Escherichia coli (EPEC) in raw yak (Poephagus grunniens) milk and milk products. Res. Vet. Sci., http://dx.doi.org/10.1016/i.rvsc.2011.12.011.

8. Baylis, C. L. 2009. Raw milk and raw milk cheeses as vehicles for infection by Verocytotoxin-producing Escherichia coli. Int. J. Dairy Technol., 62: 293-307.

9. Baylis, C. L. 2008. Growth of pure cultures of Verocytotoxin-producing Escherichia coli in a range of enrichment media. J. Appl. Microbiol., 105: 1259-1265.

10. Berry, E. D. \& Wells, J. E. 2010. Escherichia coli O157: H7: recent advances in research on occurrence, transmission, and control in cattle and the production environment. Adv. Food Nutr. Res., 60: 67-117.

11. Beutin, L., Montenegro, M. A., Orskov, I., Orskov, F., Prada, J., Zimmermann, S. and Stephan, R. 1989. Close association of verotoxin (Shiga-like toxin) production with enterohemolysin production in strains of Escherichia coli. J. Clin. Microbiol., 27: 25592564. 
Capítulo I. Bibliografía

12. Blanco, M., Blanco, J. E., Mora, A., Rey, J., Alonso, J. M., Hermoso, M., Hermoso, J., Alonso, M. P., Dahbi, G. and González, E. A. 2003. Serotypes, virulence genes, and intimin types of Shiga toxin (verotoxin)-producing Escherichia coli isolates from healthy sheep in Spain. J. Clin. Microbiol., 41: 1351-1356.

13. Caro, I., Mateo, J., Rúa, J. and García-Armesto, M. R. 2011. Occurrence of Escherichia coli 0157, 0111 and 026 in raw ewe's milk and performance of two enrichment broths and two plating media used for its assessment. Int. J. Food Microbiol., 146: 84-87.

14. Caro, I., Fernández-Barata, V. M., Alonso-Llamazares, A. and García-Armesto, M. R. 2006. Detection, occurrence, and characterization of Escherichia coli 0157:H7 from raw ewe's milk in Spain. J. Food Prot., 69: 920-924.

15. Cortés, C., De la Fuente, R., Blanco, J., Blanco, M., Blanco, J., Dhabi, G., Mora, A., Justel, P., Contreras, A. and Sanchez, A. 2005. Serotypes, virulence genes and intimin types of verotoxin-producing Escherichia coli and enteropathogenic E. coli isolated from healthy dairy goats in Spain. Vet. Microbiol., 110: 67-76.

16. D'Amico, D. J., Groves, E. and Donnelly, C. W. 2008. Low incidence of foodborne pathogens of concern in raw milk utilized for farmstead cheese production. J. Food Prot., 71: 1580-1589.

17. Díaz, S., Vidal, D., Herrera-León, S. and Sánchez, S. 2011. Sorbitol-fermenting, $\beta$ glucuronidase-positive, Shiga toxin-negative Escherichia coli O157: H7 in free-ranging red deer in south-central Spain. Foodborne Pathog. Dis., 8: 1313-1315. 
18. Dontorou, C., Papadopoulou, C., Filioussis, G., Economou, V., Apostolou, I., Zakkas, G., Salamoura, A., Kansouzidou, A. and Levidiotou, S. 2003. Isolation of Escherichia coli 0157: H7 from foods in Greece. Int. J. Food Microbiol., 82: 273-279.

19. EFSA. 2012. European Centre for Disease Prevention and Control. The European Union summary report on trends and sources of zoonoses, zoonotic agents and foodborne outbreaks in 2010. EFSA Journal, 10(3): 161-189.

20. Farrokh, C., Jordan, K., Auvray, F., Glass, K., Oppegaard, H., Raynaud, S., Thevenot, D., Condron, R., De Reu, K. and Govaris, A. 2013. Review of Shiga-toxin-producing Escherichia coli (STEC) and their significance in dairy production. Int. J. Food Microbiol., 162 (2): 190-212.

21. Feng, P. C., Jinneman, K., Scheutz, F. and Monday, S. R. 2011. Specificity of PCR and serological assays in the detection of Escherichia coli Shiga toxin subtypes. Appl. Environ. Microbiol., 77: 6699-6702.

22. Gavin, P. J., Peterson, L. R., Pasquariello, A. C., Blackburn, J., Hamming, M. G., Kuo, K. J. and Thomson, R. B. 2004. Evaluation of performance and potential clinical impact of ProSpecT Shiga toxin Escherichia coli microplate assay for detection of Shiga toxinproducing E. coli in stool samples. J. Clin. Microbiol., 42: 1652-1656.

23. Hernandes, R. T., Elias, W. P., Vieira, M. A. M. and Gomes, T. A. T. 2009. An overview of atypical enteropathogenic Escherichia coli. FEMS Microbiol. Lett., 297: 137-149. 
Capítulo I. Bibliografía

24. Hofer, E., Cernela, N. and Stephan, R. 2012. Shiga toxin subtypes associated with Shiga toxin-producing Escherichia coli strains isolated from red deer, roe deer, chamois, and ibex. Foodborne Pathog. Dis., 9: 792-795.

25. Holko, I., Bisova, T., Holkova, Z. and Kmet, V. 2006. Virulence markers of Escherichia coli strains isolated from traditional cheeses made from unpasteurised sheep milk in Slovakia. Food Control, 17: 393-396.

26. Kaspar, C., Doyle, M. E. and Archer, J. 2009. White paper on non-0157:H7 Shigatoxin producing E.coli from meat and non-meat sources. Disponible en: http://fri.wisc.edu/docs/pdf/FRI Brief NonO157STEC 4 10.pdf. Fri food safety reviews.

27. LeJeune, J. T., Besser, T. E. and Hancock, D. D. 2001. Cattle water troughs as reservoirs of Escherichia coli 0157. Appl. Environ. Microbiol., 67: 3053-3057.

28. Martin, A. \& Beutin, L. 2011. Characteristics of Shiga toxin-producing Escherichia coli from meat and milk products of different origins and association with food producing animals as main contamination sources. Int. J. Food Microbiol., 146: 99-104.

29. Meng, J., Jeffrey, T. L., Zhao, T. and Doyle, M. P. 2013. Enterohemorrhagic Eshcerichia coli. In: Doyle, M. P. and Buchanan, R. L. (Eds.), Food Microbiology: Fundamentals and Frontiers. American Society for Microbiology Press, Washington DC, USA, pp. 287-309. 
Capítulo I. Bibliografía

30. Meng, J., Doyle, M. P., Zhao, T. and Zhao, S. 2007. Enterohemorrhagic Escherichia coli. In: Doyle, M. P. and Beuchat, L. R. (Eds.), Food Microbiology: Fundamentals and frontiers. American Society for Microbiology Press, Washington DC, USA, pp. 249-269.

31. Muehlherr, J. E., Zweifel, C., Corti, S., Blanco, J. E. and Stephan, R. 2003.

Microbiological quality of raw goat's and ewe's bulk-tank milk in Switzerland. J. Dairy Sci., 86: 3849-3856.

32. Otero, V. 2013. Resultados de los programas de vigilancia analítica de la leche de tanque de los rebaños del consorcio: patógenos específicos en leche de tanque: Escherichia coli productor de toxinas Shiga (STEC). In: Gonzalo, C. (Ed.), Programas de calidad, seguridad y certificación de la leche del consorcio de promoción del ovino. Consorcio de Promoción del Ovino (CPO), Villalpando (Zamora), pp. 71-76.

33. Paton, J. C. \& Paton, A. W. 1998a. Pathogenesis and diagnosis of Shiga toxinproducing Escherichia coli infections. Clin. Microbiol. Rev., 11: 450-479.

34. Paton, A. W. \& Paton, J. C. 1998b. Detection and characterization of Shiga toxigenic Escherichia coli by using multiplex PCR assays for stx1, stx2, eaeA, enterohemorrhagic E. colihlyA, rfbO111, and rfb0157. J. Clin. Microbiol., 36: 598-602.

35. Rey, J., Sánchez, S., Blanco, J. E., Hermoso de Mendoza, J., Hermoso de Mendoza, M., García, A., Gil, C., Tejero, N., Rubio, R. and Alonso, J. M. 2006. Prevalence, serotypes and virulence genes of Shiga toxin-producing Escherichia coli isolated from ovine and caprine milk and other dairy products in Spain. Int. J. Food Microbiol., 107: 212-217. 
Capítulo I. Bibliografía

36. Sánchez, S., Martínez, R., García, A., Benítez, J. M., Blanco, J., Blanco, J. E., Blanco, M., Dahbi, G., López, C. and Mora, A. 2010a. Variation in the prevalence of non-0157 Shiga toxin-producing Escherichia coli in four sheep flocks during a 12-month longitudinal study. Small Ruminant Res., 93: 144-148.

37. Sánchez, S., Martínez, R., Rey, J., Garcia, A., Blanco, J., Blanco, M., Blanco, J. E., Mora, A., Herrera-Leon, S. and Echeita, A. 2010b. Pheno-genotypic characterisation of Escherichia coli 0157: $\mathrm{H7}$ isolates from domestic and wild ruminants. Vet. Microbiol., 142: 445-449.

38. Sánchez, S., Martínez, R., García, A., Vidal, D., Blanco, J., Blanco, M., Blanco, J. E., Mora, A., Herrera-León, S. and Echeita, A. 2010c. Detection and characterisation of 0157: H7 and non-O157 Shiga toxin-producing Escherichia coli in wild boars. Vet. Microbiol., 143: 420-423.

39. Silva, Z. N., Cunha, A. S., Lins, M. C., Carneiro, L. A. M., Almeida, A. C. F. and Queiroz, M. L. P. 2001. Isolation and serological identification of enteropathogenic Escherichia coli in pasteurized milk in Brazil. Rev. Saúde Pública, 35: 375-379.

40. Solomakos, N., Govaris, A., Angelidis, A. S., Pournaras, S., Burriel, A. R., Kritas, S. K. and Papageorgiou, D. K. 2009. Occurrence, virulence genes and antibiotic resistance of Escherichia coli $\mathrm{O} 157$ isolated from raw bovine, caprine and ovine milk in Greece. Food Microbiol., 26: 865-871. 
Capítulo I. Bibliografía

41. Vimont, A., Delignette-Muller, M. and Vernozy-Rozand, C. 2007. Supplementation of enrichment broths by novobiocin for detecting Shiga toxin-producing Escherichia coli from food: a controversial use. Lett. Appl. Microbiol., 44: 326-331.

42. Vimont, A., Vernozy-Rozand, C. and Delignette-Muller, M. L. 2006. Isolation of $E$. coli 0157:H7 and non-0157 STEC in different matrices: review of the most commonly used enrichment protocols. Lett. Appl. Microbiol., 42: 102-108.

43. Willford, J., Mills, K. and Goodridge, L. D. 2009. Evaluation of three commercially available enzyme-linked immunosorbent assay kits for detection of Shiga toxin. J. Food Prot., 72: 741-747. 


\section{CAPÍTULO II: Caracterización y}

estudio comparativo de cepas de

Escherichia coli productor de toxinas Shiga (STEC) aisladas de leche de oveja, de sus explotaciones y de pacientes 



\section{INTRODUCCIÓN}

Las cepas de Escherichia coli productoras de toxinas Shiga (STEC) se identificaron como agentes de enfermedades de transmisión alimentaria en el año 1982, cuando 47 individuos enfermaron debido al consumo de hamburguesas servidas en un establecimiento de comida rápida en los Estados Unidos de América (USA). No obstante, un estudio retrospectivo demostró que más de 3.000 cepas aisladas previamente eran similares a éstas y a la obtenida de una paciente con colitis hemorrágica en 1975. La mayoría pertenecían al serotipo 0157:H7 (Meng et al., 2013).

Las personas afectadas por cepas STEC pueden sufrir diarrea que, a su vez puede devenir en colitis hemorrágica $(\mathrm{CH})$, síndrome urémico hemolítico (SUH), otros procesos graves e, incluso, la muerte. Estas cepas pueden pertenecer a diferentes serogrupos y serotipos y sus fenotipos suelen diferir de los característicos de la cepa tipo de $E$. coli. Los serogrupos más patógenos, además del 0157, en USA, parecen ser: 026, 0111, 0103, 0121 y 0145. En la Unión Europea (UE), los serogrupos más preocupantes son los anteriores y también el 091 aunque un número mucho mayor de serogrupos y serotipos pueden producir Stxs. Por este motivo se ha propuesto clasificar las cepas STEC en cinco "seropatotipos", dependiendo de su incidencia en procesos clínicos, la gravedad de los mismos y su participación en brotes (Farrokh et al., 2013). Mención especial merece la cepa del serotipo 0104:H4 responsable del brote asociado a semillas germinadas contaminadas que afectó, en Alemania y Francia, a 3.126 individuos, otros 773 desarrollaron SUH y 46 fallecieron. Esta cepa posee factores de virulencia de E. coli enteroagregativo y también el gen stx2a de STEC (EFSA, 2011).

Todas las cepas STEC, tanto las 0157 como las no-0157, poseen los genes stxs que codifican para las toxinas Shiga (Stxs). Entre las Stxs hay dos tipos; las Stxs1 y las Stxs2 que, a su vez, muestran diferentes subtipos (Beutin et al., 2007). Las cepas clínicas suelen poseer el gen stx2 con mayor frecuencia que el sxt1, habiéndose asociado los subtipos stx2a, stx2b y stx2d con CH y SUH (Bergan et al., 2012). Además de la producción de Stxs, las cepas STEC pueden poseer otros determinantes de 
virulencia que han sido exhaustivamente tratados en el apartado "Introducción general".

El reservorio natural de STEC son los rumiantes portadores que eliminan la bacteria en sus heces. Estas ensucian las ubres y la piel y contaminan, además, el ambiente de la explotación, donde pueden permanecer durante bastante tiempo. La excreción parece ser un fenómeno esporádico, pero existen datos que demuestran que hay animales portadores durante meses. También se ha observado que la incidencia es mayor en verano. Como los animales no presentan síntomas clínicos ni lesiones, sus canales son declaradas aptas para el consumo humano tras la inspección ante y post-mortem y lo mismo ocurre con su leche. El contacto directo, tanto con personas y animales infectados como el uso de aguas de recreo, y también el agua de bebida contribuyen a la infección, aunque son los alimentos y el agua contaminados los más frecuentemente implicados (Farrokh et al., 2013).

La presencia de cepas STEC en la leche es debida, principalmente, a contaminación de origen fecal, aunque se ha sugerido la posibilidad de que cepas STEC sean agentes de mamitis subclínicas. En cualquier caso, es importante intentar saber cómo las cepas STEC se distribuyen en la explotación, cómo los animales las adquieren y cómo se contamina la leche así como la posible relación entre las cepas de origen animal y las cepas clínicas. La información sobre estos aspectos es muy escasa; tanto, que varios países que han intentado llevar a cabo una evaluación cuantitativa del riesgo asociado a la presencia de STEC en leche cruda y productos lácteos elaborados con leche cruda no han podido realizarla por "la incertidumbre" debida, principalmente, a la falta de datos (Farrokh et al., 2013).

Otro aspecto interesante es la resistencia a los antimicrobianos de las cepas STEC. Inicialmente, eran sensibles a la mayoría de los compuestos utilizados frente a bacterias Gram-negativas pero posteriormente, se ha apreciado un incremento de la resistencia tanto entre las cepas de STEC 0157 como en las no-O157. Se ha sugerido que las cepas de origen humano y las obtenidas de animales de abasto han adquirido resistencia y multi-resistencia debido al empleo de ciertos antimicrobianos en clínica humana y sanidad animal (Meng et al., 2013). 


\section{OBJETIVO}

El trabajo presentado en este Capítulo tenía varios objetivos. El primero, conocer el genotipo de cepas STEC aisladas de leche de oveja, de muestras obtenidas en explotaciones positivas -heces, agua, pienso y aire- y de coprocultivos de pacientes, prestando especial atención a los genes que codifican para factores de virulencia. En segundo lugar, comparar todas las cepas estudiadas para así poder establecer la relación existente entre ellas y el posible origen de las mismas. Finalmente, investigar los patrones de resistencia a los antimicrobianos en la población estudiada. 


\section{MATERIAL Y MÉTODOS}

\section{OBTENCIÓN DE CEPAS STEC DE PACIENTES DEL HOSPITAL DE LEÓN}

Entre los meses de Marzo y Mayo del año 2011, se recibieron cultivos procedentes del Hospital de León. Se trataba de muestras de heces de pacientes que nos llegaron de la forma siguiente:

$>$ Placas de Sorbitol MacConkey Agar suplementado con Cefixima y Telurito (CTSMAC, BioMérieux, Marcy l'Etoile, Francia) con cepas aisladas (cultivo puro).

D Placas de Columbia Agar con 5\% de sangre de oveja (Becton Dickinson, Sparks, MD, USA) con siembra directa de heces (cultivo mixto).

$>$ Placas de CT-SMAC (BioMérieux) con siembra directa de heces (cultivo mixto).

En el primer caso, la cepa se sembró en Tryptone Soya Agar (TSA, Oxoid, Basingstoke, UK), incubando las placas a 37으 durante 24 horas. Se tomó una cantidad suficiente de colonias que se guardó en Nutrient Broth (NB, Oxoid) con un $40 \%$ de Glicerol (Acofarma, Barcelona, España) a -40 으 para su posterior caracterización, incluida la detección de los genes stxs.

De las placas de Columbia Agar (Becton Dickinson) y CT-SMAC (BioMérieux) conteniendo la siembra directa de las heces, se tomó una muestra representativa del crecimiento, realizando un enriquecimiento en NB (Oxoid) con 0,6\% de Yeast Extract (YE, Oxoid) que se incubó a 37으 C durante 24 horas. Posteriormente, se procedió a investigar la presencia de los genes stxs. Los caldos de enriquecimiento positivos para alguno de estos genes, se sembraron en el medio CT-SMAC (Oxoid). Finalmente, se investigó la presencia de los genes stxs en las colonias sospechosas obtenidas de los enriquecimientos positivos. Las cepas que poseían alguno de ellos, se guardaron como en el caso anterior en NB (Oxoid) con glicerol (Acofarma) para su caracterización posterior.

Además, nos proporcionaron 14 cepas 0157:H7 aisladas de pacientes del Hospital de León entre los años 2009 y 2011. Estas últimas procedían del Instituto de Salud Carlos III (Majadahonda, Madrid). 


\section{CARACTERIZACIÓN DE CEPAS STEC}

En total, se estudió una población de 80 cepas. De ellas, 50 procedían de muestras de leche de tanque, 12 fueron obtenidas de los muestreos en explotaciones y 18 de pacientes del Hospital de León.

Las cepas obtenidas de leche se analizaron con la galería Api ${ }^{\circledR} 20 \mathrm{E}$ (BioMérieux) diseñada para la identificación de especies de bacterias pertenecientes a la familia Enterobacteriaceae y de otros géneros de bacilos Gram negativos (http://apiweb.biomerieux.com).

Los aislados de E. coli STEC se sometieron a dos pruebas de aglutinación con partículas de látex:

- Dryspot E. coli 0157 test (Oxoid), que es una prueba para la identificación de E. coli 0157.

- Dryspot E. coli Seroscreen (Oxoid), que es una prueba para la detección de seis serogrupos de E. coli no-0157: 026, 091, 0103, 0111, 0128 y 0145.

En ambos casos, se utilizan partículas azules de látex sensibilizadas con anticuerpos específicos de conejo reactivos frente al antígeno somático correspondiente, y desecadas sobre la superficie de tarjetas. Las partículas de látex aglutinan en presencia de los antígenos específicos y forman grumos visibles.

Para la realización de ambas pruebas se siguió el mismo procedimiento, partiendo de colonias obtenidas de placas de Sorbitol MacConkey Agar (SMAC, Oxoid) previamente incubadas a $37^{\circ} \mathrm{C}$ durante 24 horas.

- Se añadió una gota de tampón (Phosphate buffered saline -PBS-) (facilitado por el fabricante) en el área de prueba de la tarjeta con cuidado de que el líquido no se mezclara con los reactivos de látex desecados.

- Se tomó una colonia sospechosa con una de las espátulas suministradas con el "kit" y se aplicó sobre el área de control mezclándola con el PBS hasta la obtención de una suspensión ligeramente turbia y uniforme. 
- Se extendió con la espátula la suspensión por el área de reacción hacia las manchas de látex desecado, hasta su completa disolución cubriendo toda el área de reacción.

- En los casos en los que se produjo aglutinación, se procedió del mismo modo utilizando esta vez el látex control. Este paso se realizó para comprobar que las colonias no eran autoaglutinantes.

- Se consideró un resultado positivo cuando se produjo una aglutinación de las partículas de látex en un lapso de tiempo no superior a 60 segundos.

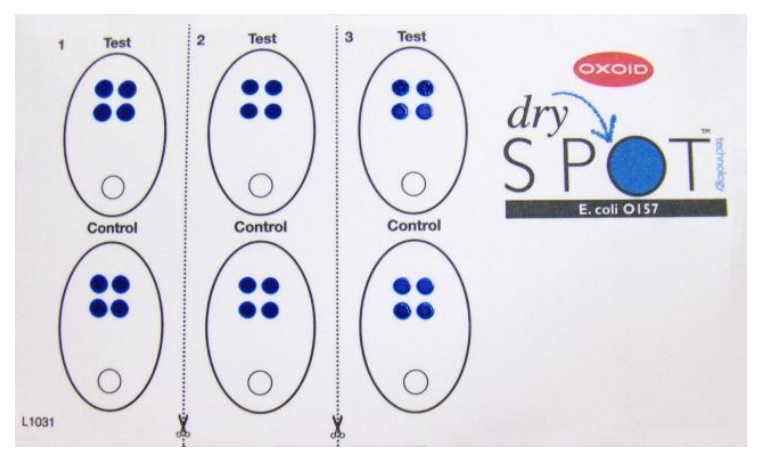

Figura II.1. Imagen de las tarjetas utilizadas para la realización de la prueba Dryspot $E$. coli $\mathrm{O} 157$ test.

A continuación se describen las pruebas realizadas a las cepas STEC 0157 y a las no-0157.

\subsection{Cepas STEC 0157}

\subsubsection{Confirmación y caracterización inicial}

Se procedió a una nueva serotipificación utilizando métodos convencionales. Así, las cepas sospechosas de ser 0157:H7; es decir, aquellas que resultaron positivas o dudosas en el "Dryspot E. coli 0157 test" se confirmaron utilizando un antisuero comercial obtenido del Stanten Serum Institut (SSI Diagnostica, Copenhague, Dinamarca). Para ello, se tomó una pequeña cantidad de crecimiento de la cepa en TSA (Becton Dickinson) que se mezcló con el suero, examinando la posible aglutinación. En los casos en los que la cepa aglutinó, se comprobó que no era autoaglutinante aplicando la misma técnica, pero en este caso, con solución salina. 
La capacidad para fermentar la lactosa y el sorbitol, la actividad $\beta$-glucuronidasa y la actividad hemolítica de los aislados 0157:H7 fue ensayada en los medios MacConkey Agar (Becton Dickinson), SMAC (Becton Dickinson), Chromocult Coliform Agar (Becton Dickinson) y Enterohaemolysin Agar (Oxoid). Para ello, las cepas se sembraron en los medios citados, incubando a $37^{\circ} \mathrm{C}$ durante 24 horas. Las características esperables en cada uno de los medios eran:

- MacConkey Agar (Becton Dickinson): las colonias con capacidad para fermentar la lactosa presentaban una coloración rosa, mientras que las que no la poseían eran incoloras.

- SMAC (Becton Dickinson): las colonias con capacidad para fermentar el sorbitol presentaban una coloración rosa, mientras que las que no la poseían eran incoloras.

- Chromocult Coliform Agar (Becton Dickinson): las colonias con actividad $\beta$ glucuronidasa positivas presentaban una coloración rosa, mientras que las que no la poseían mostraban una coloración azulada.

- Enterohaemolysin Agar (Oxoid): las colonias productoras de $\alpha$-hemolisina producían hemólisis a las 4 horas de incubación y tras 24 horas, la zona de hemólisis era bastante amplia. En el caso de producir enterohemolisina, las colonias la mostraban únicamente a partir de las 24 horas de incubación, siendo la zona de hemólisis mucho menor que en el caso de la $\alpha$-hemolisina.

\subsubsection{Detección de genes mediante $P C R$}

Posteriormente, se investigaron, mediante PCR, los genes siguientes (Tabla II.1).

$>$ Genes que codifican para las toxinas Shiga: stx1 (Pollard et al., 1990) y stx2 (Olsen et al., 1995) y los subtipos de estos genes (Scheutz et al., 2012).

$>$ Genes que codifican para los antígenos 0157 (somático 0157rfbE) (Desmarchelier et al., 1998), y H7 (flagelar fliCh7) (Gannon et al., 1997).

$>$ Gen que codifica para la intimina (eae y su variante eaev1) (Gannon et al., 1993; Oswald et al., 2000). 
Gen que codifica para la enterohemolisina (ehxA) (Wang et al., 2002).

Plásmido pO157 (pCVD419) (Fratamico et al., 1995).

Tabla II.1. Genes y cebadores utilizados en las pruebas de PCR para la caracterización de las cepas STEC 0157:H7.

\begin{tabular}{|c|c|c|c|c|}
\hline Gen Diana & Cebador & Secuencia $\left(5^{\prime} \rightarrow 3^{\prime}\right)$ & Tamaño $(p b)^{a}$ & Referencia \\
\hline \multirow{2}{*}{ stx 1} & VT1a & GAAGAGTCCGTGGGATTACG & \multirow{2}{*}{130} & \multirow{2}{*}{ (Pollard et al., 1990) } \\
\hline & VT1b & AGCGATGCAGCTATTAATAA & & \\
\hline \multirow{2}{*}{ stx 2} & SLTII1 & CTTCGGTATCCTATTCCCGG & \multirow{2}{*}{448} & \multirow{2}{*}{ (Olsen et al., 1995) } \\
\hline & SLTII2 & GGATGCATCTCTGGTCATTG & & \\
\hline \multirow{2}{*}{ eae } & SK1 & CCCGAATTCGGCACAAGCATAAGC & \multirow{2}{*}{881} & \multirow{2}{*}{ (Oswald et al., 2000) } \\
\hline & SK2 & CCCGGATCCGTCTCGCCAGTATTCG & & \\
\hline \multirow{2}{*}{ EHEC hlyA } & HlyA-a & AGCTGCAAGTGCGGGTCTG & \multirow{2}{*}{569} & \multirow{2}{*}{ (Wang et al., 2002) } \\
\hline & HlyA-b & TACGGGTTATGCCTGCAAGTTCAC & & \\
\hline \multirow{2}{*}{$0157 r f b E$} & O157AF & AAGATTGCGCTGAAGCCTTTG & \multirow{2}{*}{497} & \multirow{2}{*}{$\begin{array}{c}\text { (Desmarchelier et al., } \\
1998)\end{array}$} \\
\hline & O157AR & CATTGGCATCGTGTGGACAG & & \\
\hline \multirow{2}{*}{ flich7 } & FLICH7-F & GCGCTGTCGAGTTCTATCGAGC & \multirow{2}{*}{625} & \multirow{2}{*}{ (Gannon et al., 1997) } \\
\hline & FLICH7-R & CAACGGTGACTTTATCGCCATTCC & & \\
\hline \multirow{2}{*}{$e a e-\gamma 1$} & AE 19 & CAGGTCGTCGTGTCTGCTAAA & \multirow{2}{*}{1.087} & \multirow{2}{*}{ (Gannon et al., 1993) } \\
\hline & AE 20 & TCAGCGTGGTTGGATCAACCT & & \\
\hline \multirow{2}{*}{$p C V D 419$} & MFS1F & ACGATGTGGTTTATTCTGGA & \multirow{2}{*}{166} & \multirow{2}{*}{ (Fratamico et al., 1995) } \\
\hline & MFS1R & CTTCACGTCACCATACATAT & & \\
\hline \multirow{2}{*}{ stx1a } & stx1a-F1 & CCTTTCCAGGTACAACAGCGGTT & \multirow{2}{*}{478} & \\
\hline & stx1a-R2 & GGAAACTCATCAGATGCCATTCTGG & & \\
\hline \multirow{2}{*}{ stx $1 \mathrm{c}$} & stx1c-F1 & CCTTTCCTGGTACAACTGCGGTT & 252 & \\
\hline & stx1c-R1 & CAAGTGTTGTACGAAATCCCCTCTGA & $\angle J \angle$ & \\
\hline $\operatorname{ctv} 1 \mathrm{~d}$ & stx1d-F1 & CAGTTAATGCGATTGCTAAGGAGTTTACC & 202 & \\
\hline $\operatorname{six} x \mathrm{du}$ & stx1d-R1 & СTCTTCCTCTGGTTCTAACCCCATGATA & 203 & \\
\hline & stx2a-F2 & GCGATACTG(A/G)G(C/G)ACTGTGGCC & & \\
\hline stx $2 \mathrm{a}$ & stx2a-R3 & CCG(G/T)CAACCTTCACTGTAAATGTG & $\begin{array}{l}349 \\
347\end{array}$ & \\
\hline & stx2a-R2 & GGCCACCTTCACTGTGAATGTG & & \\
\hline $\mathrm{st} x \mathrm{2h}$ & stx2b-F1 & AAATATGAAGAAGATATTTGTAGCGGC & 251 & \\
\hline$S \tau X<D$ & stx2b-R1 & CAGCAAATCCTGAACCTGACG & 251 & (Schoutz ot al 2012) \\
\hline $\operatorname{sty} 2 \mathrm{c}$ & stx2c-F1 & GAAAGTCACAGTTTTTATATACAACGGGTA & 177 & (scneutz et al., zU12) \\
\hline & stx2c-R2 & CCGGCCAC(C/T)TTTACTGTGAATGTA & & \\
\hline & stx2d-F1 & AAA(A/G)TCACAGTCTTTATATACAACGGGTG & & \\
\hline$s t \times 2 d$ & stx2d-R1 & TT(C/T)CCGGCCACTTTTACTGTG & $\begin{array}{l}1 / 9 \\
280\end{array}$ & \\
\hline & stx2d-R2 & GCCTGATGCACAGGTACTGGAC & & \\
\hline strope & stx2e-F1 & CGGAGTATCGGGGAGAGGC & 11 & \\
\hline stx $<\mathrm{e}$ & stx2e-R2 & CTTCCTGACACCTTCACAGTAAAGGT & 411 & \\
\hline $\operatorname{sty} 2 \mathrm{f}$ & stx2f-F1 & TGGGCGTCATTCACTGGTTG & 424 & \\
\hline$s(x<1$ & stx2f-R1 & TAATGGCCGCCCTGTCTCC & $4 \angle 4$ & \\
\hline & stx2g-F1 & CACCGGGTAGTTATATTTCTGTGGATATC & & \\
\hline$s \tau x<g$ & stx2g-R1 & GATGGCAATTCAGAATAACCGCT & & \\
\hline
\end{tabular}

\footnotetext{
$\mathrm{pb}$ : Pares de bases
} 
Las condiciones de la PCR fueron diferentes en función de los genes que se buscaban. En el caso de los genes que codifican para las toxinas Shiga (stx1 y stx2), la Intimina (eae) y la Enterohemolisina (ehxA) se realizó una desnaturalización inicial a 95으 durante 5 minutos, seguida de 25 ciclos, cada uno de ellos compuesto por tres pasos, un primer paso de desnaturalización a 95ㄷ $\mathrm{C}$ durante 30 segundos, un segundo de hibridación a 56 ㅇ C durante 40 segundos y una elongación a 72ำ durante 1 minuto. Finalmente, se realizó un último paso de elongación final a 72ํㄷ durante 7 minutos.

Las condiciones de la PCR para los subtipos de los genes de las toxinas Shiga fueron: una desnaturalización inicial a 95으 durante 5 minutos, seguida de 25 ciclos compuestos por tres pasos, un primer paso de desnaturalización a 94 ํC durante 50

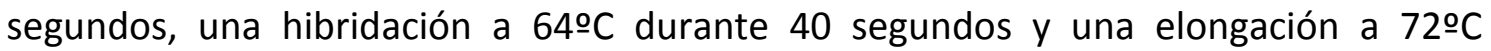
durante 40 segundos. Tras los ciclos se realizó una elongación final a $72{ }^{\circ} \mathrm{C}$ durante 7 minutos.

En el caso de los genes que codifican para los antígenos 0157 (somático O157rfbE) y $\mathrm{H} 7$ (flagelar flich7), la variante de la intimina $\mathrm{\gamma} 1$ (eaev1) y el plásmido p0157 las condiciones de la PCR fueron las siguientes: una desnaturalización previa a 94으 $\mathrm{C}$ durante 5 minutos seguida de 25 ciclos compuestos por tres pasos, un primer

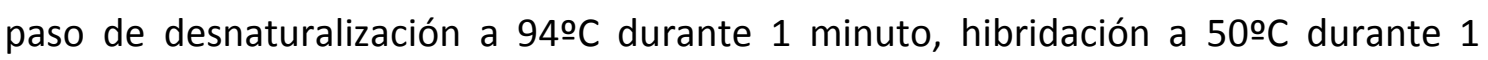
minuto y elongación a $72{ }^{\circ} \mathrm{C}$ durante 2 minutos. Tras los 25 ciclos, un último paso de elongación a $72^{\circ} \mathrm{C}$ durante 7 minutos.

La amplificación de estos genes se realizó en un equipo Applied Biosystems 2720 Thermal Cycler (Life Technologies S.A., Applied Biosystems división, Madrid, España).

El producto de la PCR fue sometido a electroforesis en un gel de agarosa (Pronadisa, Chemie Brunschwig, Basel, Suiza) al 1,5\% en Tris-Acetic Acid-EDTA (TAE, Laboratorios Conda, Madrid, España) y para su revelado se utilizó una solución (10 $\mathrm{mg} / \mathrm{ml}$ ) de bromuro de etidio (AppliChem, Darmstadt, Alemania). Los resultados se observaron exponiendo el gel en un transiluminador (Bio-Rad Laboratories, Hercules, CA, USA) a la luz ultravioleta y se realizó la captura de la imagen mediante el equipo Molecular Imager GelDoc XR System (Bio-Rad Laboratories). La concentración del gel 
de agarosa en el caso de los genes que codifican las toxinas Shiga y los subtipos de estas toxinas fue del 1,8\% para facilitar la separación de los productos de PCR.

\subsubsection{Fagotipado}

El fagotipado de las cepas se realizó mediante el método descrito por Khakhria et al. (1990). Se llevó a cabo en el Centro Nacional de Microbiología (Instituto de Salud Carlos III, Madrid, España) utilizando los fagos facilitados por el "National Microbiology Laboratory" (Public Health Agency of Canada, Winnipeg, Canada). Un total de 90 fagotipos pueden ser identificados mediante el uso de 16 bacteriófagos diferentes.

Se partió de un cultivo fresco en TSA (Becton Dickinson) tanto de las cepas a fagotipar como de los controles. Se transfirió una pequeña cantidad del crecimiento a caldo común (Becton Dickinson) con $\mathrm{NaCl}$ al $0,85 \%$ y se incubó a 37으 con agitación entre una y dos horas aproximadamente. Transcurrido este tiempo, se sembraron las placas de agar común (Becton Dickinson) con $\mathrm{NaCl}$ al 0,85\%, inundando las placas con el caldo, y dejando secar unos minutos. Una vez secas las placas, se depositó una gota de cada suspensión de los 16 bacteriófagos, utilizando unas plantillas y se dejó secar a temperatura ambiente hasta que las gotas se absorbieron. Posteriormente se incubaron a $37^{\circ} \mathrm{C}$ durante 24 horas y se leyeron las placas de lisis. Se compararon los resultados con un esquema establecido en el que la combinación de las lisis producidas por los 16 fagos se corresponde con un fagotipo determinado.

\subsubsection{Resistencia a antimicrobianos}

El antibiograma de las cepas se llevó a cabo mediante un método de difusión en agar de acuerdo con los criterios del EUCAST (European Committee on Antimicrobial Susceptibility Testing) (EUCAST, 2012a). Se utilizaron un total de 13 discos (Oxoid) en el antibiograma y nueve más en el antibiograma ampliado. 
Tabla II.2. Antimicrobianos utilizados y sus concentraciones en los discos. Los nueve últimos antibióticos fueron los utilizados en el antibiograma ampliado.

\begin{tabular}{ccc}
\hline & Antimicrobiano & Concentración \\
\hline AMP & Ampicilina & $10 \mu \mathrm{g}$ \\
\hline $\mathrm{S}$ & Estreptomicina & $10 \mu \mathrm{g}$ \\
\hline $\mathrm{KF}$ & Cefalotina & $30 \mu \mathrm{g}$ \\
\hline $\mathrm{NA}$ & Ácido Nalidíxico & $30 \mu \mathrm{g}$ \\
\hline $\mathrm{CTX}$ & Cefotaxima & $30 \mu \mathrm{g}$ \\
\hline $\mathrm{TE}$ & Tetraciclina & $30 \mu \mathrm{g}$ \\
\hline AMC & Amoxicilina - Ácido Clavulánico & $30 \mu \mathrm{g}$ \\
\hline SXT & Trimetoprim - Sulfametoxazol & $25 \mu \mathrm{g}$ \\
\hline $\mathrm{CN}$ & Gentamicina & $10 \mu \mathrm{g}$ \\
\hline $\mathrm{CIP}$ & Ciprofloxacina & $5 \mu \mathrm{g}$ \\
\hline $\mathrm{K}$ & Kanamicina & $30 \mu \mathrm{g}$ \\
\hline $\mathrm{C}$ & Cloranfenicol & $30 \mu \mathrm{g}$ \\
\hline S3 & "Compound sulphonamides” & $300 \mu \mathrm{g}$ \\
\hline FOX & Cefoxitina & $30 \mu \mathrm{g}$ \\
\hline FEP & Cefepima & $30 \mu \mathrm{g}$ \\
\hline CEC & Cefaclor & $30 \mu \mathrm{g}$ \\
\hline TIC & Ticarcilina & $75 \mu \mathrm{g}$ \\
\hline CAZ & Ceftazidima & $30 \mu \mathrm{g}$ \\
\hline ATM & Aztreonam & $30 \mu \mathrm{g}$ \\
\hline PRL & Piperaciclina & $30 \mu \mathrm{g}$ \\
\hline CXM & Cefuroxima & $30 \mu \mathrm{g}$ \\
\hline IPM & Imipenem & $10 \mu \mathrm{g}$ \\
\hline & &
\end{tabular}

Se utilizaron placas de Mueller Hinton Agar (Becton Dickinson). Se partió de una placa de TSA (Becton Dickinson) con cultivo puro y a continuación se realizaron los pasos siguientes:

- Preparación del inóculo: Se dispersaron varias colonias en solución salina hasta lograr una suspensión uniforme de una turbidez comparable al valor 0,5 de la escala de McFarland.

- Inoculación de las placas: La suspensión se utilizó antes de transcurrir 15 minutos una vez preparada. Se introdujo una torunda de algodón en la suspensión, eliminando el exceso de líquido presionando la torunda contra las paredes del tubo. Se distribuyó el inóculo uniformemente sobre la superficie de la placa sembrando en tres direcciones. 
- Almacenamiento de los discos de antimicrobianos: Los discos se almacenaron a $4-8$ - $C$ en recipientes cerrados con un desecador y protegidos de la luz. Antes de abrir los envases, se dejó que alcanzaran la temperatura ambiente para evitar condensación de agua.

- Aplicación de los discos: Se colocaron en un plazo inferior a 15 minutos tras la inoculación de las placas, procurando que contactaran bien con la superficie del medio y una distribución adecuada de forma que los halos de inhibición, de las cepas sensibles, no se superpusieran.

- Incubación: En los 15 minutos siguientes a la aplicación de los discos durante un período de $16-20$ horas a $35 \pm 1$ 으.

El método utilizado cumplía la "Regla" de los 15-15-15 minutos (EUCAST, 2012a) que consiste en lo siguiente:

- Usar el inóculo dentro de los 15 minutos después de su preparación y nunca más allá de los 60 minutos.

- Colocar los discos dentro de los 15 minutos después de inoculadas las placas.

- Iniciar la incubación dentro de los 15 minutos después de la aplicación de los discos.

Tras la incubación, se midieron los halos de inhibición utilizando un calibre y también una hoja de cálculo para discriminar entre cepas sensibles (S), intermedias (I) y resistentes (R) en función de los diámetros que se presentan en la Tabla II.3. 
Tabla II.3. Diámetros de las zonas de inhibición utilizados para clasificar las cepas STEC como resistentes $(\mathrm{R})$, intermedias (I) o sensibles (S) a un antibiótico.

\begin{tabular}{|c|c|c|c|c|}
\hline \multirow{2}{*}{ Agente Antimicrobiano } & \multicolumn{3}{|c|}{ Diámetro zona inhibición (mm) } & \multirow[t]{2}{*}{ Referencia } \\
\hline & $\mathbf{R}$ & $\mathbf{I}$ & $\mathbf{S}$ & \\
\hline Ampicilina & $<14$ & & $\geq 14$ & \multirow{14}{*}{$\begin{array}{c}\text { (EUCAST, } \\
2012 b)\end{array}$} \\
\hline Cefotaxima & $<17$ & & $\geq 20$ & \\
\hline Amoxicilina - Ácido Clavulánico & $<17$ & & $\geq 17$ & \\
\hline Trimetoprim - Sulfametoxazol & $<13$ & & $\geq 16$ & \\
\hline Gentamicina & $<14$ & & $\geq 17$ & \\
\hline Ciprofloxacina & $<19$ & & $\geq 22$ & \\
\hline Cloranfenicol & $<17$ & & $\geq 17$ & \\
\hline Cefepima & $<21$ & & $\geq 24$ & \\
\hline Ticarcilina & $<23$ & & $\geq 23$ & \\
\hline Ceftazidima & $<19$ & & $\geq 22$ & \\
\hline Aztreonam & $<24$ & & $\geq 27$ & \\
\hline Piperaciclina & $<15$ & & $\geq 18$ & \\
\hline Cefuroxima & $<18$ & & $\geq 18$ & \\
\hline Imipenem & $<16$ & & $\geq 22$ & \\
\hline Estreptomicina & $\leq 11$ & $12-14$ & $\geq 15$ & \multirow{8}{*}{$\begin{array}{c}\text { (Clinical and } \\
\text { Laboratory } \\
\text { Standards } \\
\text { Institute, 2005) }\end{array}$} \\
\hline Cefalotina & $\leq 14$ & $15-17$ & $\geq 18$ & \\
\hline Ácido Nalidíxico & $\leq 13$ & $14-18$ & $\geq 19$ & \\
\hline Tetraciclina & $\leq 14$ & $15-18$ & $\geq 19$ & \\
\hline Kanamicina & $\leq 12$ & $13-14$ & $\geq 15$ & \\
\hline "Compound sulphonamides" & $\leq 12$ & $13-16$ & $\geq 17$ & \\
\hline Cefoxitina & $\leq 14$ & $15-17$ & $\geq 18$ & \\
\hline Cefaclor & $\leq 14$ & $15-17$ & $\geq 18$ & \\
\hline
\end{tabular}

En las cepas resistentes a uno o más antibióticos se investigó el determinante que confería la resistencia. Se realizaron pruebas de PCR para detectar los genes implicados en la resistencia a los diferentes antibióticos además de un integrón de clase I (Tabla II.4). 
Tabla II.4. Cebadores utilizados en la detección de resistencia a antimicrobianos.

\begin{tabular}{|c|c|c|c|c|c|}
\hline Diana & Cebador & Secuencia $\left(5^{\prime} \rightarrow 3^{\prime}\right)$ & $\begin{array}{c}\text { Tamaño } \\
(\mathbf{p b})^{\mathrm{a}}\end{array}$ & Referencia & $\begin{array}{c}\text { Condiciones } \\
\text { PCR }^{\text {b }}\end{array}$ \\
\hline \multirow[t]{2}{*}{ Integrón clase I } & $5 \mathrm{CS}$ & GGCATCCAAGCAGCAAGC & \multirow[t]{2}{*}{ variable } & \multirow[t]{2}{*}{ (Guerra et al., 2004) } & \multirow{2}{*}{$A$} \\
\hline & $3 \mathrm{CS}$ & AAGCAGACTTGACCTGAT & & & \\
\hline \multirow[t]{2}{*}{ catA1 } & catF & CCACCGTTGATATATCCC & \multirow[t]{2}{*}{623} & \multirow{2}{*}{ (Guerra et al., 2001) } & \multirow{2}{*}{$A$} \\
\hline & catB & CCTGCCACTCATCGCAGT & & & \\
\hline \multirow[t]{2}{*}{ tetA } & tetA-F & GCTACATCCTGCTTGCCT & \multirow[t]{2}{*}{210} & \multirow{2}{*}{ (Guerra et al., 2004) } & \multirow{2}{*}{ A } \\
\hline & tetA-B & CATAGATCGCCGTGAAGA & & & \\
\hline \multirow[t]{2}{*}{ tetB } & tetB-F & TTGGTTAGGGGCAAGTTTTG & \multirow[t]{2}{*}{600} & \multirow{2}{*}{ (Ng et al., 1999) } & \multirow{2}{*}{$A$} \\
\hline & tetB-B & GTAATGGGCCAATAACACCG & & & \\
\hline \multirow[t]{2}{*}{ tetD } & tetD-F & AAACCATTACGGCATTCTGC & \multirow[t]{2}{*}{787} & \multirow{2}{*}{ (Ng et al., 2001) } & \multirow{2}{*}{ A } \\
\hline & tetD-R & GACCGGATACACCATCCATC & & & \\
\hline \multirow[t]{2}{*}{ floR } & FloF & CACGTTGAGCCTCTATAT & \multirow[t]{2}{*}{868} & \multirow{2}{*}{ (Guerra et al., 2001) } & \multirow{2}{*}{$A$} \\
\hline & FloB & ATGCAGAAGTAGAACGCG & & & \\
\hline \multirow[t]{2}{*}{ strA } & strA-F & CCTGGTGATAACGGCAATTC & 548 & & \\
\hline & strA-B & CCAATCGCAGATAGAAGG & & (Guerra et al., 2004) & A \\
\hline strB & strB-F & ATCGTCAAGGGATTGAAACC & 509 & (Madsen et al., & $A$ \\
\hline & strB-B & GGATCGTAGAACATATTGGC & & 2000) & $A$ \\
\hline cmlA1-like & $\mathrm{cmlA}-\mathrm{F}$ & TGTCATTTACGGCATACTCG & 435 & & $A$ \\
\hline & $\mathrm{cmlA}-\mathrm{B}$ & ATCAGGCATCCCATTCCCAT & & (Guerra et al., zUU1) & A \\
\hline Cat2 & Cat2-F & CCGGATTGACCTGAATACCT & 567 & (Randallet al 2004) & $A$ \\
\hline & Cat2-R & TCACATACTGCATGATGAAC & & (Indiludall et di., 2004) & $A$ \\
\hline Cat3 & $\mathrm{C}-3$ & CCATACTCATCCGATATTGA & 275 & $003)$ & $A$ \\
\hline cats & $C-R$ & CCATCACATACTGCATGATG & 210 & (roo el al., 20Us) & A \\
\hline Cat4 & C-4 & CCGGTAAAGCGAAATTGTAT & 451 & (Yonet al 2003) & $A$ \\
\hline Cut4 & C-R & CCATCACATACTGCATGATG & $4 J 1$ & (100 el dl., 2000 ) & $\mathrm{H}$ \\
\hline sul2 & sulll-F & TCAACATAACCTCGGACAGT & 707 & (Chuet al 2001 ) & $A$ \\
\hline & sulll-B & GATGAAGTCAGCTCCACCT & & (chu el al., zoul) & A \\
\hline CMY2 & CMY2-F & CTGCGCTCTGCTGCTGACAGC & 1093 & (González-Sanz et & $R$ \\
\hline & CMY2-R & CTCGACACGGACAGGGTTAGG & & al., 2009) & $\mathrm{D}$ \\
\hline$D H A$ & DHA-F & CTGATGAAAAAATCGTTATC & 1141 & (Yan et al 2002 ) & $\mathrm{B}_{2}$ \\
\hline & DHA-R & ATTCCAGTGCACTCAAAATA & & (ran el al., $200<$ ) & $\mathrm{D}$ \\
\hline SHV & SHV-F & CCCTGTTAGCCACCCTGCCG & 829 & (González-Sanz et & 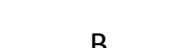 \\
\hline & SHV-R & CGTTGCCAGTGCTCGATCAGC & & al., 2009) & $\mathrm{D}$ \\
\hline pse1 & pse1-F & CGCTTCCCGTTAACAAGTAC & 419 & (Sandvang et al., & 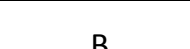 \\
\hline & pse1-B & CTGGTTCATTTCAGATAGCG & & 1998) & $D$ \\
\hline OXA1 & OXA1-F & ATGAAAACACAATACATATCAACTTCG & 820 & (González-Sanz et & $B_{1}$ \\
\hline & OXA1-R & GTGTGTTTAGAATGGGTGATCGCATT & & al., 2009) & D \\
\hline$C T X-M$ & ctxM-F & ATGTGCAG(C/T)ACCAGTAA(A/G)GT & 593 & (Paganiet al 2003) & $B$ \\
\hline & ctxM-R & TGGGT(A/G)AA(A/G)TA(A/G)GT(G/C)ACCAGA & & 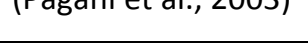 & $D$ \\
\hline TEM & TEM-F & GTATTCAACATTTCCGTGTCG & 854 & (González-Sanz et & $B$ \\
\hline & TEM-R & CCAATGCTTAATCAGTGAGGC & & al., 2009) & \\
\hline$a v r A$ & GYRA-P1 & TGTCCGAGATGGCCTGAAGC & 347 & (Griggset al 1996) & $C$ \\
\hline УуІн & GYRA-P2 & TACCGTCATA(G/C)GTTATCCACG & & (UIISgs el di., 1500) & $c$ \\
\hline
\end{tabular}

La amplificación de estos genes se realizó utilizando el equipo Applied Biosystems 2720 Thermal Cycler (Life Technologies). Las condiciones de la PCR se 
presentan en la Figura II.2. El revelado del producto de PCR se realizó tal y como se ha descrito anteriormente.

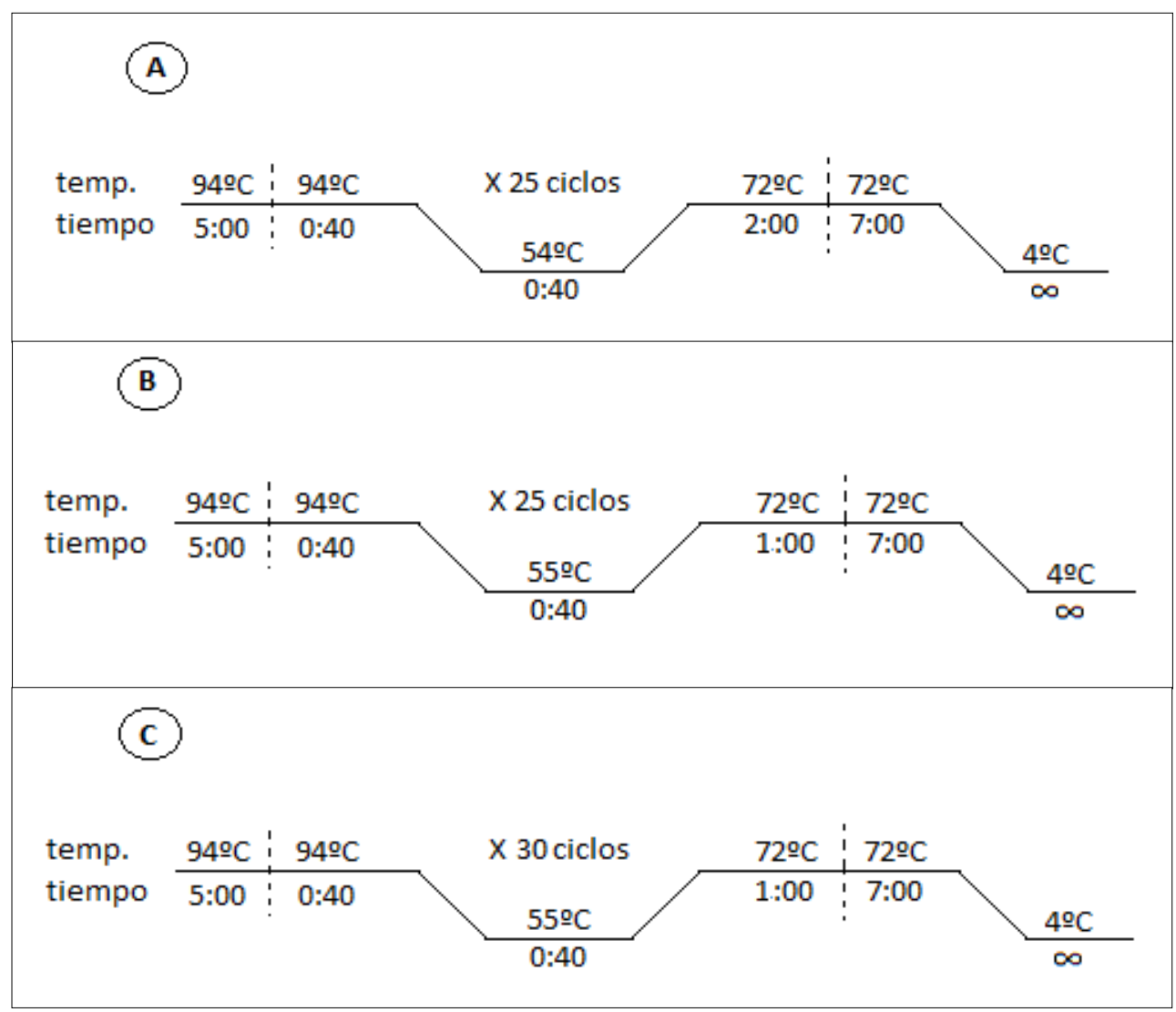

Figura II.2. Condiciones del método PCR utilizadas en la detección de genes de resistencia a antibióticos.

Además, los productos obtenidos en la PCR del Integrón de clase I y de los genes TEM y gyrA fueron purificados y posteriormente secuenciados. Se utilizó el "kit" de purificación Invisorb ${ }^{\circledR}$ Fragment ClearUp (I. enzimanvitek, STRATEC Molecular $\mathrm{GmbH}$, Berlín, Alemania). El protocolo de purificación consistió en lo siguiente:

- Se añadió al producto de la PCR, $400 \mu l$ de "Binding Enhancer" (facilitado por el fabricante). Esta mezcla se añadió a la columna, facilitada por el fabricante, colocada previamente en un tubo de $2 \mathrm{ml}$ también facilitado por el fabricante.

- Se centrifugó a 12.000 rpm durante un minuto y posteriormente se descartó el filtrado.

- Se añadieron $700 \mu \mathrm{l}$ de "Wash Buffer" (facilitado por el fabricante) y se centrifugó a 12.000 rpm durante un minuto descartando el filtrado y volviendo a centrifugar en vacío en las mismas condiciones. 
- Se colocó la columna en un tubo eppendorf de 1,5 ml, se le añadieron $30 \mu \mathrm{l}$ de "Elution Buffer" (facilitado por el fabricante) y se mantuvo a temperatura ambiente durante un minuto.

- Finalmente, se centrifugó a 12.000 rpm durante un minuto quedando en el tubo eppendorf el producto purificado.

Los purificados se secuenciaron en un equipo 3730XL (Life Technologies) y las secuencias obtenidas se analizaron utilizando los programas del software Lasergene Core Suite versión 7.0.0 (DNAStar, Inc. Madison, WI, USA). El programa BLAST del "National Center for Biotechnology Information" (http://blast.ncbi.nlm.nih.gov/Blast.cgi) se utilizó para la comparación (alineamiento) de las secuencias en una base de datos de nucleótidos.

El protocolo descrito por Yan et al. (2002) se empleó para la detección de la enzima beta-lactamasa $\mathrm{AmpC}$ cromosómica inducible. La técnica consiste en realizar un antibiograma (ya descrito), colocando un agente inductor en el centro de la placa de Mueller Hinton Agar (Becton Dickinson). En este caso el agente inductor utilizado fue Cefoxitina. A continuación, se colocaron los cuatro discos de cefalosporinas separados $25 \mathrm{~mm}$ del centro como se muestra en la Figura II.3. Las cefalosporinas utilizadas fueron: Ceftacidima, Cefotaxima, Aztreonam y Cefepima.

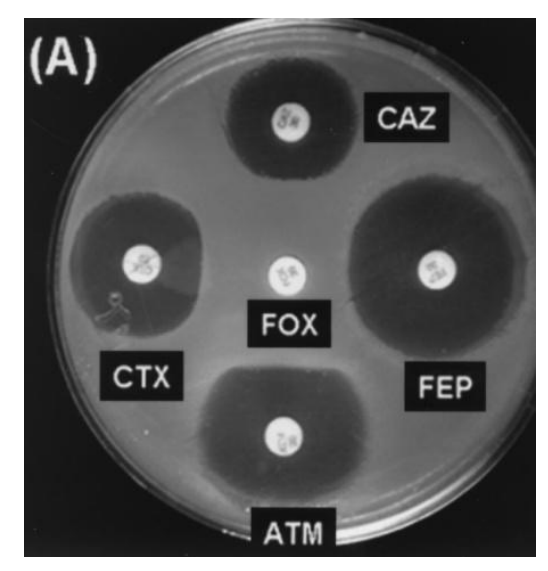

Figura II.3. Colocación de los discos utilizados para el "double-disk antagonism test" (Yan et al., 2002). 


\subsubsection{Electroforesis en Gel de Campo Pulsado (PFGE)}

La técnica PFGE se realizó de acuerdo con el método descrito por PulseNet (http://www.pulsenetinternational.org). Básicamente, el protocolo consiste en lo siguiente:

- Siembra de las cepas en placas de TSA (Becton Dickinson) e incubación a 37ㄷ durante 18-24 horas.

- Preparación de las suspensiones celulares. Para ello, se añadieron $2 \mathrm{ml}$ de Cell Suspension Buffer (CSB) (100 mM Tris: 100 mM EDTA, pH 8) a cada tubo (tubo extra para ajustar la concentración). Se suspendió en el CSB la suficiente cantidad del crecimiento bacteriano en TSA (Becton Dickinson), se homogeneizó y se midió la absorbancia a $420 \mathrm{~nm}$, ajustando a 0,6 en $400 \mu \mathrm{l}$ de CSB. A cada uno de estos tubos se añadieron $20 \mu \mathrm{l}$ de Proteinasa K (Fermentas, Thermo Fisher, Waltham, MA, USA) a una concentración de $20 \mathrm{mg} / \mathrm{ml}$, obteniendo una concentración final de $0,5 \mathrm{mg} / \mathrm{ml}$.

- Preparación de los bloques de agarosa. Se utilizó "Seakem Gold agarose for PFGE" (Lonza, Rockland, ME, USA) al 1\% en TE Buffer (10 Mm Tris: 1 mM EDTA, pH 8). Se atemperó a 55ำ y a continuación se añadió SDS (dodecilsulfato sódico, Panreac Química, S.L.U, Barcelona, España), obteniendo una concentración final del $1 \%$. Se mezclaron $400 \mu \mathrm{l}$ de agarosa con el mismo volumen de suspensión bacteriana y se dispensaron en los moldes. Se dejó solidificar a temperatura ambiente durante 15 minutos y a continuación cinco minutos más a refrigeración.

- Lisis bacteriana en los bloques de agarosa. Los bloques solidificados se sumergieron en $5 \mathrm{ml}$ de Cell Lysis Buffer (50 mM Tris: 50 mM EDTA, pH $8+1 \%$ Sarcosyl) con $25 \mu \mathrm{l}$ de Proteinasa K (Fermentas) a una concentración de 20 $\mathrm{mg} / \mathrm{ml}$ obteniendo una concentración final de $0,1 \mathrm{mg} / \mathrm{ml}$. Se incubaron los "plugs" sumergidos en el Cell Lysis Buffer a 55ㄷ con agitación (150-175 rpm) durante dos horas. 
- Lavado de los bloques de agarosa. En primer lugar, se realizaron dos lavados con $10 \mathrm{ml}$ de agua estéril y tres lavados con $10 \mathrm{ml}$ de TE Buffer. Estos lavados se realizaron a 50ㄷ C y con agitación (150-175 rpm).

- Digestión del ADN. Para ello, se cortó un trozo (inserto) del bloque de agarosa que se sumergió en una solución de Buffer H (Fermentas) (10 $\mu$ l de Buffer H + $90 \mu \mathrm{l}$ de agua miliQ estéril) para realizar la preincubación a 37으 durante 10 minutos. Posteriormente se continuó con la digestión de los insertos utilizando $10 \mathrm{U} / \mu \mathrm{l}$ de la enzima Xba I (Fermentas), incubándose a 370 C durante un mínimo de tres horas.

- Preparación del gel de agarosa. Se utilizó "Seakem Gold agarose" (Laboratorios Conda) al 1\% en tampón TBE 0,5X (Tris-Borate EDTA Buffer, Scharlab, Barcelona, España). Se atemperó a 55으 antes de su utilización. Se colocaron los insertos en los extremos del peine colocando posteriormente este peine en el molde para el gel.

- Electroforesis en el equipo Cheff DR III (Bio-Rad Laboratories). Se Ilenó la cubeta de electroforesis con dos litros de tampón TBE 0,5X (Scharlab) y se ajustó la temperatura a $14 \stackrel{\circ}{ } \mathrm{C}$. Las condiciones de electroforesis utilizadas fueron las siguientes:
○ Pulso inicial: 2,2
○ Pulso final: 54,2
- Voltaje: $6 \mathrm{~V}$
○ Ángulo de inclinación: 120은
o Tiempo: 21 horas

- Tinción del gel. Se llevó a cabo al finalizar la electroforesis en un baño con 10 $\mathrm{mg} / \mathrm{ml}$ de Bromuro de etidio (AppliChem) durante al menos 30 minutos y posteriormente, se sumergió el gel en agua destilada al menos una hora. Se observaron los resultados exponiendo el gel a la luz ultravioleta en un transiluminador (Bio-Rad Laboratories). Se realizó la captura de la imagen mediante el equipo Molecular Imager GelDoc XR System (Bio-Rad Laboratories).

- Análisis de imágenes y posterior obtención de dendrogramas mediante el uso del software GelCompar II 6.5 (Applied Maths, Kortfijk, Belgica). 


\subsection{STEC no-0157}

\subsubsection{Caracterización fenotípica}

La capacidad para fermentar la lactosa y el sorbitol de las cepas STEC no-0157 se investigó en la forma descrita para las cepas STEC O157:H7.

\subsubsection{Detección de genes mediante $P C R$}

Los genes investigados (PCR) en los aislados de STEC no-0157 se detallan en la Tabla II. 5. Se investigaron:

Genes que codifican para las toxinas Shiga stx1 (Pollard et al., 1990) y stx2 (Olsen et al., 1995) y sus subtipos (Scheutz et al., 2012).

$>$ Gen que codifica para la Intimina (eae) (Oswald et al., 2000).

$>$ Gen que codifica para la Enterohemolisina (ehxA) (Wang et al., 2002).

$>$ Genes que codifican la Subtilasa (SubAB) (Paton et al., 2004) y sus dos variantes alélicas $\left(S u b A B_{1}\right.$ y $S u b A B_{2}$ ) (Michelacci et al., 2013), la adhesina autoaglutinante (saa) (Paton \& Paton, 2002) y el "toxigenic invasión loci A" (tia) (Tozzoli et al., 2010). 
Tabla II.5. Genes investigados (PCR) para la caracterización de las cepas STEC no-O157.

\begin{tabular}{|c|c|c|c|c|c|}
\hline Diana & Cebador & Secuencia $\left(5^{\prime} \rightarrow 3^{\prime}\right)$ & $\begin{array}{c}\text { Tamaño } \\
(\mathrm{pb})^{\mathrm{a}}\end{array}$ & Referencia & $\begin{array}{c}\text { Condiciones } \\
\text { PCR }^{\text {b }}\end{array}$ \\
\hline \multirow{2}{*}{ stx 1} & VT1a & GAAGAGTCCGTGGGATTACG & \multirow{2}{*}{130} & (Pollard et & \multirow{2}{*}{$\mathrm{A}$} \\
\hline & VT1b & AGCGATGCAGCTATTAATAA & & al., 1990) & \\
\hline \multirow{2}{*}{ stx2 } & SLTII1 & CTTCGGTATCCTATTCCCGG & \multirow{2}{*}{448} & (Olsen et al., & \multirow{2}{*}{$A$} \\
\hline & SLTII2 & GGATGCATCTCTGGTCATTG & & 1995) & \\
\hline \multirow{2}{*}{ eae } & SK1 & CCCGAATTCGGCACAAGCATAAGC & \multirow{2}{*}{881} & (Oswald et & \multirow{2}{*}{$A$} \\
\hline & SK2 & CCCGGATCCGTCTCGCCAGTATTCG & & al., 2000) & \\
\hline \multirow{2}{*}{$\begin{array}{c}\text { EHEC } \\
\text { hlyA }\end{array}$} & HlyA-a & AGCTGCAAGTGCGGGTCTG & \multirow{2}{*}{569} & (Wang et al., & \multirow{2}{*}{$A$} \\
\hline & HlyA-b & TACGGGTTATGCCTGCAAGTTCAC & & 2002) & \\
\hline \multirow{2}{*}{$\operatorname{sub} A B$} & RTsubABF & GCAGATAAATACCCTTCACTTG & \multirow{2}{*}{230} & (Paton et al., & \multirow{2}{*}{ B } \\
\hline & RTsubABR & ATCACCAGTCCACTCAGCC & & 2004) & \\
\hline \multirow{2}{*}{$\operatorname{SubAB_{1}}$} & SubAF & GTACGGACTAACAGGGAACTG & \multirow{2}{*}{1300} & (Michelacci & \multirow{4}{*}{$\mathrm{C}$} \\
\hline & RTsubABR & ATCACCAGTCCACTCAGCC & & et al., 2013) & \\
\hline \multirow{2}{*}{ SubAB $B_{2}$} & SubA-startF & CCCTGTAACATATTGACCAGCA & \multirow{2}{*}{1200} & (Michelacci & \\
\hline & RTsubABR & ATCACCAGTCCACTCAGCC & & et al., 2013) & \\
\hline \multirow{2}{*}{ saa } & SAADF & CGTGATGAACAGGCTATTGC & \multirow{2}{*}{119} & (Paton \& & \multirow{2}{*}{$\mathrm{D}$} \\
\hline & SAADR & ATGGACATGCCTGTGGCAAC & & Paton, 2002) & \\
\hline \multirow{2}{*}{ tia } & tia_lo & TCCATGCGAAGTTGTTATCA & \multirow{2}{*}{$\begin{array}{c}580 \\
(1800)\end{array}$} & (Tozzoli et al., & $\mathrm{F}$ \\
\hline & tia_sense & TTCTCTTTTTACCCTGCTTTTTGG & & 2010) & E \\
\hline flic & FliCECF & CAAGTCATTAATA(A/C)AACAGCC & $900-$ & (Machado et & \\
\hline JIIC & FliCECR & GACAT(A/G)TT(A/G)GA(G/A/C)ACTTC(G/C)GT & 2600 & al., 2000) & A \\
\hline cty1 & stx1a-F1 & CCTTTCCAGGTACAACAGCGGTT & 170 & & \\
\hline $\operatorname{six} \perp a$ & stx1a-R2 & GGAAACTCATCAGATGCCATTCTGG & $4 / 8$ & & \\
\hline sty $1 \mathrm{c}$ & stx1c-F1 & CCTTTCCTGGTACAACTGCGGTT & 252 & & \\
\hline $\operatorname{six} \perp C$ & stx1c-R1 & CAAGTGTTGTACGAAATCCCCTCTGA & $\angle 5 \angle$ & & \\
\hline & stx1d-F1 & CAGTTAATGCGATTGCTAAGGAGTTTACC & & & \\
\hline stxid & stx1d-R1 & CTCTTCCTCTGGTTCTAACCCCATGATA & 203 & & \\
\hline & stx2a-F2 & GCGATACTG(A/G)G(C/G/T)ACTGTGGCC & & & \\
\hline stx $2 a$ & stx2a-R3 & CCGKCAACCTTCACTGTAAATGTG & $\begin{array}{l}349 \\
347\end{array}$ & & \\
\hline & stx2a-R2 & GGCCACCTTCACTGTGAATGTG & & & \\
\hline strah & stx2b-F1 & AAATATGAAGAAGATATTTGTAGCGGC & 251 & & \\
\hline$S \tau X \angle \mathrm{D}$ & stx2b-R1 & CAGCAAATCCTGAACCTGACG & 251 & (Scheutz et & $\mathrm{F}$ \\
\hline$s+x 2 c$ & stx2c-F1 & GAAAGTCACAGTTTTTATATACAACGGGTA & 177 & al., 2012) & \\
\hline$s t x<C$ & stx2c-R2 & CCGGCCAC(C/T)TTTACTGTGAATGTA & $1 / /$ & & \\
\hline & stx2d-F1 & AAA(A/G)TCACAGTCTTTATATACAACGGGTG & & & \\
\hline$s t \times 2 d$ & stx2d-R1 & TT(C/T)CCGGCCACTTTTACTGTG & $\begin{array}{l}1 / 9 \\
280\end{array}$ & & \\
\hline & stx2d-R2 & GCCTGATGCACAGGTACTGGAC & & & \\
\hline ctv? & stx2e-F1 & CGGAGTATCGGGGAGAGGC & 411 & & \\
\hline stx $<\mathrm{e}$ & stx2e-R2 & CTTCCTGACACCTTCACAGTAAAGGT & 411 & & \\
\hline$s+x 2 f$ & stx2f-F1 & TGGGCGTCATTCACTGGTTG & 424 & & \\
\hline$s t x<\uparrow$ & stx2f-R1 & TAATGGCCGCCCTGTCTCC & $4 \angle 4$ & & \\
\hline & stx2g-F1 & CACCGGGTAGTTATATTTCTGTGGATATC & 73 & & \\
\hline stx $<g$ & stx2g-R1 & GATGGCAATTCAGAATAACCGCT & 13 & & \\
\hline
\end{tabular}

ap: Pares de bases

${ }^{\mathrm{b}}$ Condiciones de PCR de acuerdo a la Figura II.4.

En la Figura II.4. se presentan las condiciones de las distintas PCRs. 


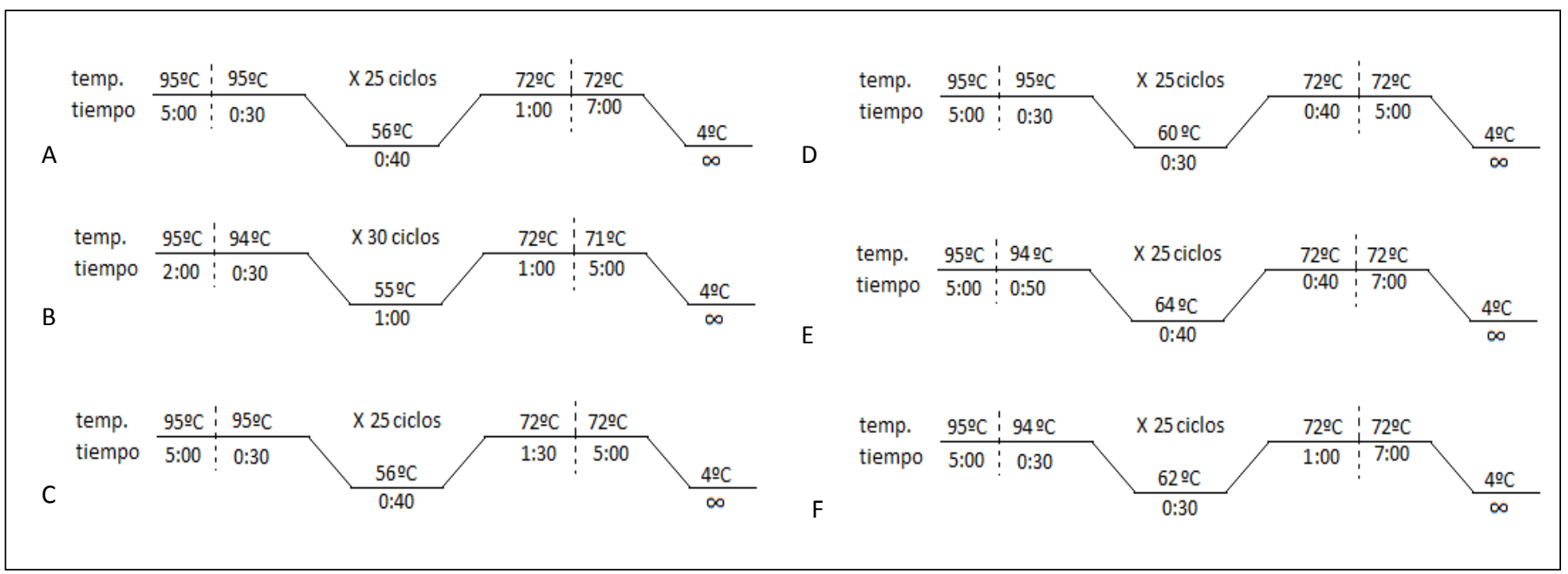

Figura II.4. Condiciones de las técnicas de PCR utilizadas para la detección de genes en cepas de STEC no-0157.

Además, se realizaron PCRs para la detección de los antígenos somáticos de seis serogrupos comúnmente asociados a enfermedad en el hombre: 045 (Lin et al., 2011), O26, 0103, 0111, 0121 y 0145 (Monday et al., 2007). También se investigaron los antígenos somáticos de los serogrupos: 0104 (Bugarel et al., 2010) (asociado a un importante brote en Alemania y Francia en el año 2011), 091 (Perelle et al., 2004), 0146 (Liu et al., 2007) y 0128 (Lin et al., 2011) (de interés clínico y frecuente en cepas de ovino). Los cebadores utilizados en las correspondientes PCR se muestran en la Tabla II.6.

Las condiciones de la PCR fueron las siguientes: en primer lugar, se realizó una desnaturalización a 95ำ durante cinco minutos, seguida de 25 ciclos, cada uno de ellos con tres pasos; el primero, de desnaturalización a $94^{\circ} \mathrm{C}$ durante 30 segundos, el segundo de hibridación a $62^{\circ} \mathrm{C}$ durante 30 segundos y, el tercero, una elongación a $72{ }^{\circ} \mathrm{C}$ durante un minuto. El paso final fue una elongación a $72 \circ \mathrm{C}$ durante siete minutos.

Para la amplificación se utilizó el equipo Applied Biosystems 2720 Thermal Cycler (Life Technologies) y para la observación de resultados se procedió tal y como se ha descrito para las cepas 0157:H7. 
Tabla II.6. Cebadores utilizados en las pruebas de PCR para la detección de antígenos somáticos para las cepas STEC no-0157.

\begin{tabular}{|c|c|c|c|c|c|}
\hline Serogrupo & Diana & Cebador & Secuencia $\left(5^{\prime} \rightarrow 3^{\prime}\right)$ & Tamaño $(\mathrm{pb})^{\mathrm{a}}$ & Referencia \\
\hline \multirow{2}{*}{026} & \multirow{2}{*}{$w z x$} & $5^{\prime} 026$ & ACTCTTGCTTCGCCTGTT & \multirow{2}{*}{268} & \multirow{10}{*}{ (Monday et al., 2007) } \\
\hline & & $33^{\prime} \mathrm{O} 26$ & CAGCGATACTTTGAACCTTAT & & \\
\hline \multirow{2}{*}{0103} & \multirow{2}{*}{$w z x$} & $5 ' 0103$ & TATCCTTCATAGCCTGTTGTT & \multirow{2}{*}{320} & \\
\hline & & 3'0103 & AATAGTAATAAGCCAGACACCTG & & \\
\hline \multirow{2}{*}{0111} & \multirow{2}{*}{$w z x$} & $5 ' 0111.3$ & GTTGCGAGGAATAATTCTTCA & \multirow{2}{*}{829} & \\
\hline & & 3'0111,2 & CCATAGATATTGCATAAAGGC & & \\
\hline \multirow{2}{*}{0121} & \multirow{2}{*}{$w z x$} & $5^{\prime} 0121$ & GTAGCGAAAGGTTAGACTGG & \multirow{2}{*}{651} & \\
\hline & & 3'0121 & ATGGGAAAGCTGATACTGC & & \\
\hline \multirow{2}{*}{0145} & \multirow{2}{*}{$w z x$} & $5 ' 0145.6$ & TTGAGCACTTATCACAAGAGATT & \multirow{2}{*}{418} & \\
\hline & & 3'0145.B & GATTGAATAGCTGAAGTCATACTAAC & & \\
\hline \multirow{2}{*}{$\mathrm{O} 45$} & \multirow{2}{*}{$w z y$} & 5 '045 & TACGATTTCACAAGCTTCCA & \multirow{2}{*}{254} & \multirow{2}{*}{ (Lin et al., 2011) } \\
\hline & & 3'045 & TGCAATCGCATAAGGAAATA & & \\
\hline \multirow{2}{*}{0104} & \multirow{2}{*}{$w z x$} & 5'0104 & TGTCGCGCAAAGAATTTCAAC $^{b}$ & \multirow{2}{*}{99} & \multirow{2}{*}{ (Bugarel et al., 2010) } \\
\hline & & 3'0104 & AAAATCCTTTAAACTATACGCCC & & \\
\hline \multirow{2}{*}{091} & \multirow{2}{*}{$w z y$} & $5 ' 091$ & CGATTTTCTGGAATGCTTGATG & \multirow{2}{*}{105} & \multirow{2}{*}{ (Perelle et al., 2004) } \\
\hline & & 3'091 & CAATACATAGTTTGATTTGTGTTTAAAGTTTAAT & & \\
\hline \multirow{2}{*}{0146} & \multirow{2}{*}{$w z y$} & 5 '0146 & ATTCGGGTAACGACCCTGTGTTGA & \multirow{2}{*}{378} & \multirow{2}{*}{ (Liu et al., 2007) } \\
\hline & & 3'0146 & AGACTGCTAATGCAAGGAACATGG & & \\
\hline \multirow{2}{*}{0128} & \multirow{2}{*}{$w z x$} & $5^{\prime} 0128$ & TCGATCGTCTTGTTCAGGTT & \multirow{2}{*}{195} & \multirow{2}{*}{ (Lin et al., 2011) } \\
\hline & & 3'0128 & GAATGCAATGGGCAATTAAC & & \\
\hline
\end{tabular}

ap: Pares de bases

${ }^{\mathrm{b}}$ hebra complementaria

Las cepas positivas para alguno de estos serogrupos, se confirmaron mediante el uso de un antisuero comercial (Stanten Serum Institut -SSI Diagnostica-). Para ello, se tomó parte de una colonia en TSA (Becton Dickinson), se mezcló con el suero correspondiente y se observó la aglutinación. Cuando la cepa aglutinaba, se comprobó que no era autoaglutinante utilizando solución salina.

En las cepas en las que se detectaron alguno de los antígenos somáticos investigados, se buscó (PCR) el gen que codifica para el antígeno H (flagelar fliC) (Machado et al., 2000). Posteriormente, el resultado de estas PCR se purificó con el kit de purificación Invisorb ${ }^{\circledR}$ Fragment ClearUp (I. enzimanvitek) y se secuenció (Secuenciador 3730XL, Life Technologies). Las secuencias obtenidas se analizaron utilizando los programas del software Lasergene Core Suite (DNAStar). El programa BLAST del "National Center for Biotechnology Information" (NCBI) (http://blast.ncbi.nlm.nih.gov/Blast.cgi) se utilizó para la comparación (alineamiento) de las secuencias en una base de datos de nucleótidos. 


\subsubsection{Resistencia a antibióticos}

El protocolo seguido es el que se describió para las cepas STEC 0157:H7 en el apartado 2.1.4 del material y métodos de este Capítulo.

\subsubsection{Electroforesis en Campo Pulsado (PFGE)}

El protocolo seguido es el que se describió para las cepas STEC 0157:H7 en el apartado 2.1.5 del material y métodos de este Capítulo aunque con una variación que consistía en lo siguiente: durante la electroforesis, se llenó la cubeta con dos litros de tampón TBE 0,5X (Scharlab) al que se le añadió tiourea (Alfa Aesar, Karlsruhe, Alemania) a una concentración final de $0,4 \mu \mathrm{l} / \mathrm{ml}$. La tiourea evita la degradación del ADN durante la electroforesis. 


\section{RESULTADOS}

\section{GENES stxs EN LAS CEPAS CLÍNICAS}

De los coprocultivos enviados a nuestro laboratorio por el Hospital de León, se aislaron cuatro cepas de E. coli STEC que fueron no-O157 (véase más adelante). Estas, sumadas a las 14 proporcionadas por el Instituto de Salud Carlos III (E. coli STEC O157) constituían una población de 18 cepas. La distribución de genes stxs en las cepas clínicas se presenta en la Tabla II.7.

Tabla II.7. Genes stxs en 18 cepas procedentes de coprocultivos del Hospital de León.

\begin{tabular}{cccc}
\hline \multirow{2}{*}{ Cepas clínicas } & \multicolumn{3}{c}{ Genotipo } \\
\cline { 2 - 4 } & stx1+ & stx2+ & stx1+/stx2+ \\
\hline 18 & $3(16,7 \%)$ & $10(55,5 \%)$ & $5(27,8 \%)$ \\
\hline
\end{tabular}

\section{CARACTERIZACIÓN DE LAS CEPAS DE E. coli STEC DE ORIGEN OVINO}

El sistema $\mathrm{Api}^{\circledR} 20 \mathrm{E}$ identificó las 50 cepas, procedentes de leche de tanque, como E. coli (41 -82\%-), Enterobacter cloacae (4 -8\%-), Hafnia alvei (2 -4\%-), Raoultella ornithinolytica (1-2\%-), Serratia liquefaciens (1 -2\%-) y Pseudomonas aeruginosa (1-2\%-).

De las 62 cepas de origen ovino (50 de leche de tanque y 12 medioambientales), cuatro (tres de leche y una del agua de bebida, obtenidas en diferentes explotaciones) fueron positivas en el Dryspot E. coli 0157 test (Oxoid) y ninguna en el Dryspot E. coli Seroscreen (Oxoid).

\section{CEPAS DE E. coli STEC 0157:H7}

Se estudiaron 18 cepas de E. coli $0157: \mathrm{H7}$; de las cuales, cuatro eran de origen ovino y 14 clínicas cedidas por el Instituto de Salud Carlos III (coprocultivos aislados en el Hospital de León). 


\subsection{Confirmación y caracterización}

La serotipificación por métodos convencionales confirmó que las cuatro cepas ovinas que fueron positivas en el Dryspot E. coli 0157 test y las 14 facilitadas por el Instituto de Salud Carlos III presentaban el antígeno 0157.

Todas ellas fermentaban la lactosa pero no el sorbitol, carecían de actividad $\beta$ glucuronidasa y producían enterohemolisina (Figura II.5).

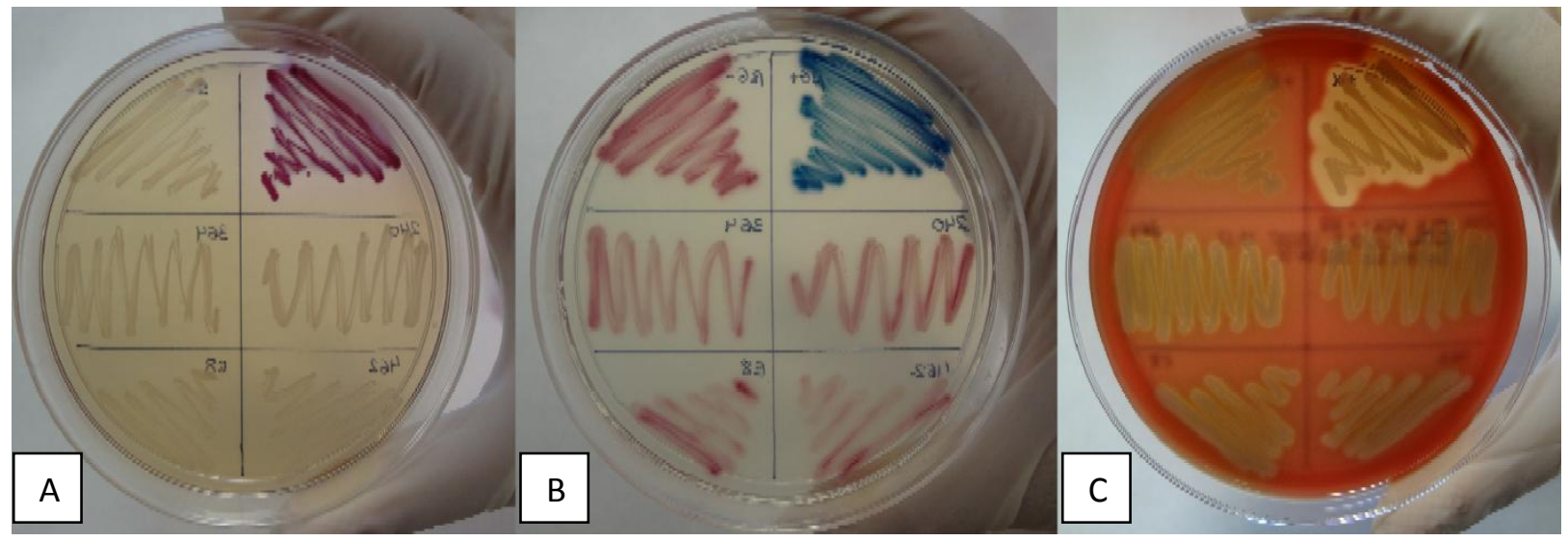

Figura II.5. Crecimiento de cepas en los medios SMAC (A), Chromocult coliform Agar (B) y Enterohaemolysin Agar (C). Las dos siembras superiores corresponden a cepas sorbitol negativo (izquierda) y sorbitol positivo (derecha) (A); $\beta$-glucuronidasa negativo (izquierda) y positivo (derecha) (B); enterohemólisis (izquierda) y $\alpha$-hemólisis (derecha) (C).

\subsection{Detección de genes mediante PCR}

Las 18 cepas presentaron los genes que codifican para los antígenos somático 0157 (O157rfbE) y flagelar H7 (flich7), el gen que codifica para la intimina (eae) y su variante eaev1, el plásmido p0157 (Pcvd419) y el gen que codifica para la enterohemolisina (exhA).

Del total, 13 cepas $(72,2 \%)$ poseían el gen stx2 (entre ellas, las de origen ovino) y cinco $(27,8 \%)$ el stx 1 y el stx2. Entre estas últimas, tres (60\%) presentaban el subtipo stx2c, una (20\%) el subtipo stx2a y la restante (20\%) los subtipos stx2a y stx2c. En todas las cepas que presentaban el gen que codifica para la toxina Stx1 se detectó el subtipo stx1a. Las cepas que poseían únicamente el gen que codifica para la toxina Stx2 eran del subtipo stx2c. 
En la Tabla II.8 y la Figura II.6 se resumen los subtipos de genes que codifican para las toxinas Shiga (stxs) presentes en las 18 cepas de E. coli O157:H7.

Tabla II.8. Distribución de las 18 cepas de E. coli $0157: \mathrm{H7}$ en función de los subtipos de genes stxs que presentaban.

\begin{tabular}{ccccc}
\hline Total cepas & \multicolumn{4}{c}{ Subtipos de genes stx } \\
\cline { 2 - 5 } 0157:H7 & stx1a+stx2a & stx1a+stx2c & stx1a+stx2a+stx2c & stx2c \\
\hline 18 & $1(5,5 \%)$ & $3(16,8 \%)$ & $1(5,5 \%)$ & $13(72,2 \%)$ \\
\hline
\end{tabular}

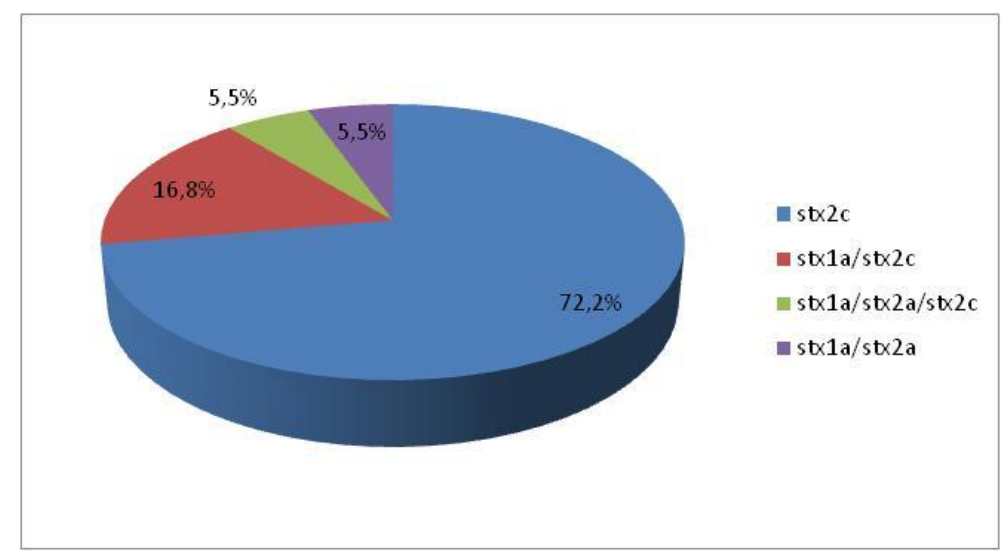

Figura II.6. Representación gráfica de la distribución de los subtipos de genes stxs.

\subsection{Fagotipado}

Las cuatro cepas de origen ovino y tres de las de origen humano pertenecían al fagotipo 54 (38,9\%). El resto pertenecían a los fagotipos 8 (16,7\%), 14 (11,2\%), 32 (11,2\%), $34(5,5 \%), 70(5,5 \%)$ y $71 p r o v(5,5 \%)$. Una de las cepas presentó un patrón de lisis no reconocible (PNR) (Figura II.7). 


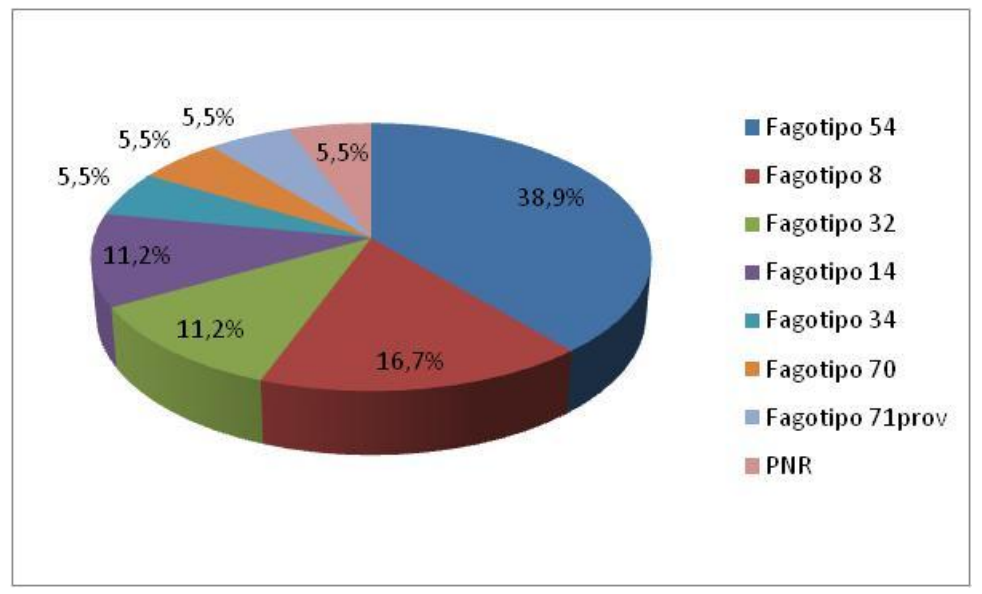

Figura II.7. Representación gráfica de la distribución de las cepas 0157:H7 en función de su fagotipo.

\subsection{Resistencia a antimicrobianos}

Ninguna de las cepas de origen ovino mostró resistencia a los antimicrobianos ensayados. Sin embargo, siete de las cepas de origen humano presentaron resistencia a uno o más de estos compuestos. En la Tabla II.9 se presentan estos datos.

Tabla II.9. Resistencia de siete cepas de E. coli 0157:H7.

\begin{tabular}{cc}
\hline CEPA & Antimicrobianos $^{\mathbf{a}}$ \\
\hline $2818 / 09$ & NA \\
\hline $3360 / 09$ & TE \\
\hline $3361 / 09$ & TE \\
\hline $3362 / 09$ & TE \\
\hline $3697 / 10$ & S, NA, TE, SXT, C, S3 \\
\hline $4594 / 10$ & S, TE, SXT, S3 \\
\hline $3643 / 11$ & S, S3
\end{tabular}

\footnotetext{
${ }^{\mathrm{a}} \mathrm{NA}$, ácido nalidíxico; TE, tetraciclina; $\mathrm{S}$, estreptomicina; SXT, trimetoprim sulfametoxazol; C, cloranfenicol; S3, "compound sulphonamides".
}

En estas siete cepas se buscó el determinante que confería la resistencia (Tabla II.10). 
Tabla II.10. Resistencias a antimicrobianos y determinantes de la resistencia en siete cepas de E. coli O157:H7.

\begin{tabular}{|c|c|c|c|c|c|c|}
\hline \multirow{2}{*}{ CEPA } & \multicolumn{6}{|c|}{ ANTIMICROBIANOS $^{\mathrm{a}}$} \\
\hline & $S$ & NA & TE & SXT & C & S3 \\
\hline $2818 / 09$ & & gyrA mutación QRDR & & & & \\
\hline $3360 / 09$ & & & tetA & & & \\
\hline $3361 / 09$ & & & tetA & & & \\
\hline $3362 / 09$ & & & tetA & & & \\
\hline $3697 / 10$ & aadA1 & gyrA mutación QRDR & tetA & $d f r A 1$ & CatA1 & sul1 \\
\hline $4594 / 10$ & aadA1 & & tetA & dfrA1 & & sul1 \\
\hline $3643 / 11$ & strA/strB & & & & & sul2 \\
\hline
\end{tabular}

\subsection{Electroforesis en Gel de Campo Pulsado (PFGE)}

El genotipado de las 18 cepas de E. coli O157:H7 dio lugar a 17 patrones de bandas diferentes. Con al menos un $86,4 \%$ de similitud, se pudieron diferenciar tres "clusters" o pulsotipos (Figura II. 8). En esta Figura, se proporciona también información acerca del origen, los subtipos de los genes stxs, los fagotipos y la resistencia a antimicrobianos de cada una de las cepas.

El pulsotipo I incluía cuatro cepas de origen humano, tres de ellas con un mismo perfil de genes de virulencia (stx1a, stx2c). Todas excepto una (3697/10) pertenecían al fagotipo 8 y dos de ellas eran resistentes a varios antimicrobianos.

Con un $88,2 \%$ de similitud, el pulsotipo II estaba formado por ocho cepas (cuatro de origen ovino y cuatro clínicas). Las de origen ovino (M240VO, M364VO, M462VO y F8VO) presentaban un $90,1 \%$ de similitud con dos de las cepas clínicas (3535/09 y 3147/10). Todas ellas presentaban el mismo perfil de genes de virulencia (stx2c). Por lo que respecta al fagotipo, las cepas de origen ovino pertenecían al fagotipo 54 y las de origen humano a diversos fagotipos. Ninguna era resistente a los antimicrobianos ensayados.

Las cepas de origen ovino se agruparon con un $92,6 \%$ de similitud. La cepa de agua de bebida (F8VO) procedente de una explotación presentaba un 97,4\% de similitud con una cepa de leche de tanque (M364VO) aislada en una explotación diferente. 
Capítulo II. Resultados

El pulsotipo III estaba constituido por tres cepas de origen humano aisladas en el año 2009 (3360/09, 3361/09 y 3362/09). Estas presentaban un 94,4\% de similitud, mostrando dos de ellas (3360/09 y 3362/09) un perfil idéntico. Además, poseían los mismos genes de virulencia (stx2c), el mismo fagotipo (54) y eran resistentes a la tetraciclina debido a la presencia del gen tetA. 


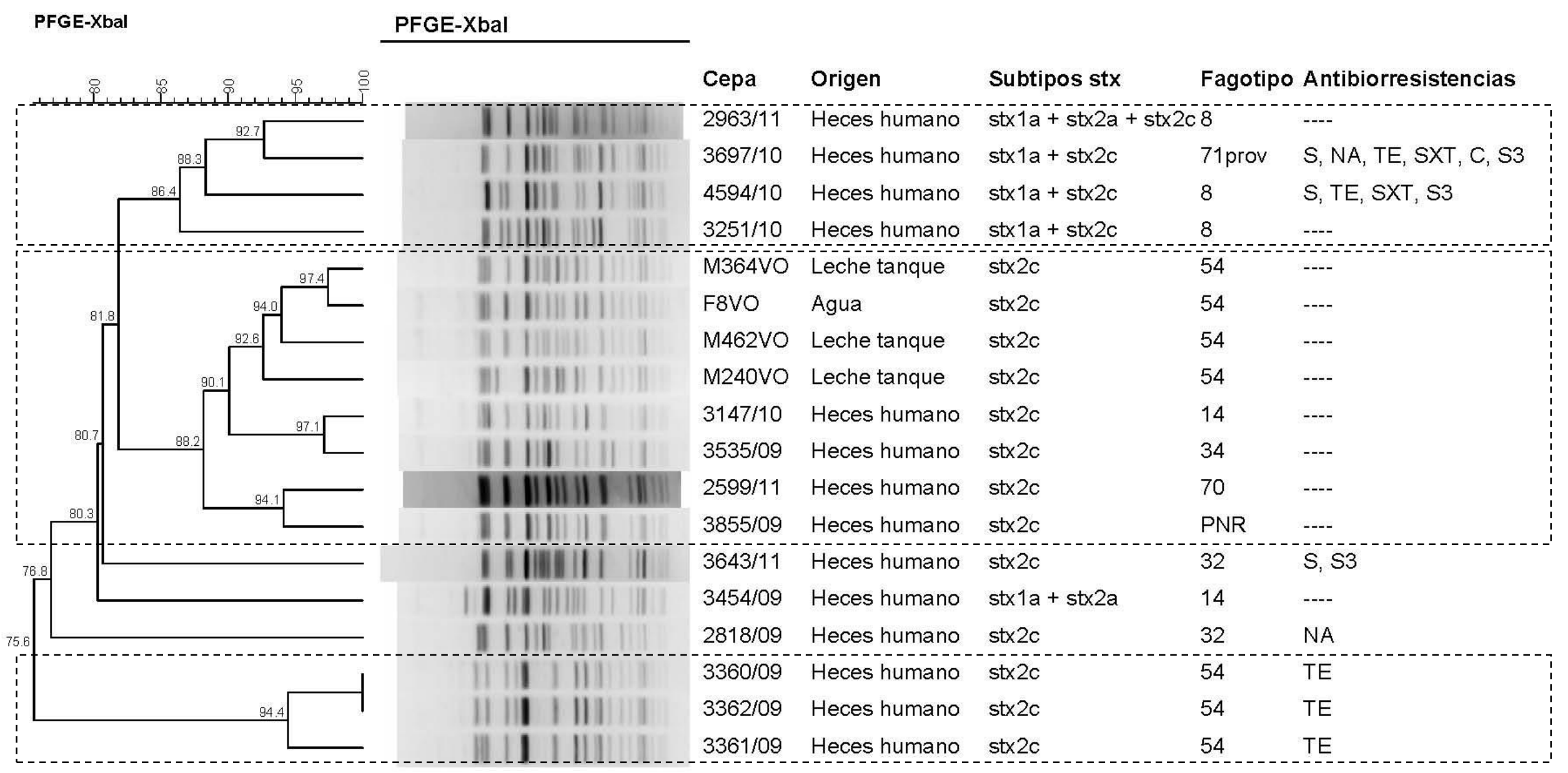

Figura II.8. Dendrograma Xbal-PFGE que muestra la relación genética entre las 18 cepas de E. coli O157:H7 de origen ovino y humano. También proporciona información acerca de los subtipos de stxs, fagotipos y resistencia a antimicrobianos. 


\section{CEPAS DE E. coli STEC NO-0157}

Se estudiaron 62 cepas de E. coli STEC no-O157. De ellas, 58 (93,5\%) eran de origen ovino y cuatro (6,5\%) fueron aisladas por nosotros de los coprocultivos proporcionados por el Hospital de León. Entre las primeras, 47 (81,1\%) procedían de muestras de leche de tanque, $10(17,2 \%)$ de muestras de heces de oveja y una $(1,7 \%)$ del agua de bebida de una explotación.

\subsection{Caracterización fenotípica}

De las 62 cepas estudiadas, $39(62,9 \%)$ fermentaron la lactosa y $23(37,1 \%)$ no lo hicieron. Para el sorbitol, $19(30,6 \%)$ fueron positivas y $43(69,4 \%)$ negativas.

\subsection{Detección de genes mediante PCR}

En esta población, 50 cepas $(80,7 \%)$ poseían sólo el gen stx 1 , una $(1,6 \%)$ el gen stx2 y $11(17,7 \%)$ ambos.

En cuanto a los subtipos de genes stxs (Tabla II.11); de las 61 cepas que albergaban el gen stx 1,57 (93,5\%) presentaron el subtipo stx1c y cuatro (6,5\%) el subtipo stx1a. Las 12 cepas que poseían el gen stx 2 pertenecían al subtipo stx2b.

Tabla II.11. Distribución de las cepas de E. coli STEC no-0157 en función de los subtipos de genes stxs que poseían.

\begin{tabular}{ccccc}
\hline Total cepas no- & \multicolumn{4}{c}{ Subtipos de genes stx } \\
\cline { 2 - 5 } $\mathbf{0 1 5 7}$ & stx1a & stx1c & stx2b & stx1c+stx2b \\
\hline 62 & $4(6,5 \%)$ & $46(74,2 \%)$ & $1(1,6 \%)$ & $11(17,7 \%)$ \\
\hline
\end{tabular}

El gen que codifica para la intimina (eae) se halló en cuatro $(6,5 \%)$ cepas que poseían también el subtipo stx1a. Dos procedían de muestras de leche de tanque y dos de pacientes. Todas las cepas salvo una poseían el gen exhA. En la Figura II.9 se presenta la distribución de las cepas de acuerdo con la presencia de los genes eae, exhA, stxs y los subtipos de estos últimos. 


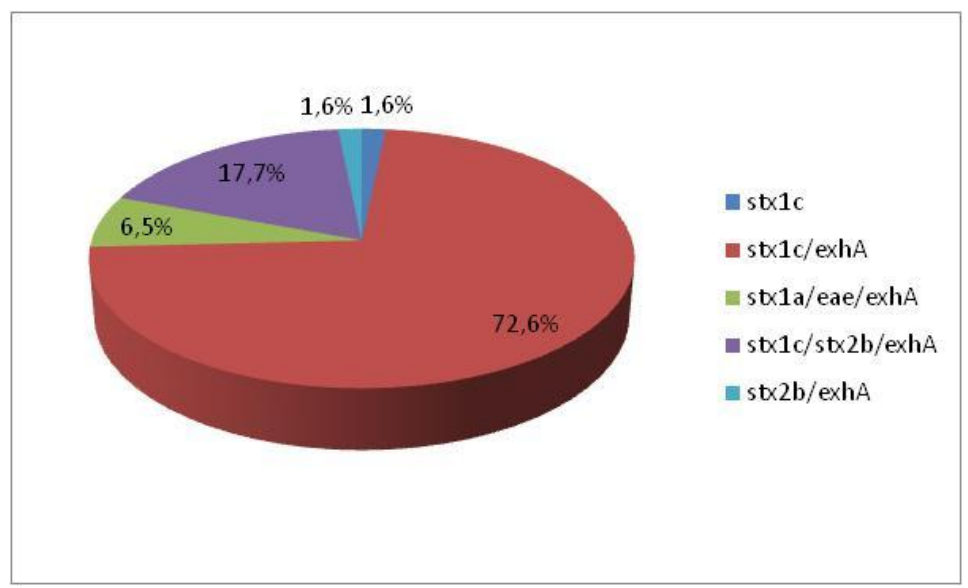

Figura II.9. Distribución de las cepas de E. coli STEC no-O157 en función de la presencia de los genes eae, exhA, stxs y los subtipos de estos últimos.

Un total de 25 cepas $(40,3 \%)$ poseían el gen que codifica para la subtilasa $(S u b A B)$ (21 procedían de muestras de leche de tanque, tres de heces de ovino y una de pacientes). De ellas, 17 (68\%) presentaban la variante $S u b A B_{2}$ y 21 (84\%) el "toxigenic invasión loci A" (tia). Ambos genes se hallaron juntos en 13 cepas (Tabla II.12). Ninguna de las cepas presentó el gen que codifica para la otra variante alélica de la subtilasa ni la adhesina autoaglutinante $(s a a)$.

Tabla II.12. Distribución de las cepas de E. coli STEC no-0157 positivas al gen que codifica para la subtilasa $(S u b A B)$ en función de la presencia de su variante alélica $S u b A B_{2}$ y del "toxigenic invasión loci A" (tia).

\begin{tabular}{cccc}
\hline Cepas no-0157 SubAB+ & SubAB $_{2}$ & tia & SubAB $_{2}+$ tia \\
\hline 25 & $4(16 \%)$ & $8(32 \%)$ & $13(52 \%)$ \\
\hline
\end{tabular}

Cuando los antígenos se investigaron mediante PCR, se detectó, en tres cepas, el antígeno 0146 y, en una, el antígeno O26. En ellas se buscó y secuenció el gen que codifica para el antígeno flagelar $\mathrm{H}$ (flagelar fliC), identificando los siguientes serotipos:

- 0146:H21: Las tres cepas de este serotipo procedían, dos de leche y una de un paciente.

- O26:H11: Una cepa clínica.

Como no se pudo determinar el serogrupo de las otras dos cepas clínicas (C74VO y C180VO), éstas se enviaron al Staten Serum Institute (Copenhague, 
Dinamarca) para su serotipificación convencional. La cepa C74VO pertenecía al serotipo O176:H- y la C180VO al O98:H-.

\subsection{Resistencia a antimicrobianos}

Se investigó la sensibilidad de las 62 cepas de E. coli STEC no-0157. Nueve de ellas mostraron resistencia a uno o más de los antimicrobianos ensayados. Seis procedían de muestras de leche y las otras tres de muestras de heces ovinas. En la Tabla II.13 se indican las cepas resistentes y los compuestos correspondientes.

Tabla II.13. Perfil de resistencia a antimicrobianos de nueve cepas de E. coli STEC No0157.

\begin{tabular}{cc}
\hline CEPA & Antimicrobianos $^{\text {a }}$ \\
\hline M208VO & $\mathrm{S}, \mathrm{TE}, \mathrm{S3}$ \\
\hline $\mathrm{M} 279 \mathrm{aVO}$ & $\mathrm{AMP}, \mathrm{S}, \mathrm{S3}$ \\
\hline $\mathrm{M} 279 \mathrm{bVO}$ & $\mathrm{AMP}, \mathrm{S}, \mathrm{S3}$ \\
\hline $\mathrm{M} 298 \mathrm{~V} \mathrm{AMP}, \mathrm{KF}, \mathrm{C}$ \\
\hline $\mathrm{M} 299 \mathrm{~V} O$ & $\mathrm{C}$ \\
\hline $\mathrm{M} 329 V O$ & $\mathrm{KF}$ \\
\hline F1VO & $\mathrm{S}, \mathrm{TE}, \mathrm{S3}$ \\
\hline F3VO & $\mathrm{AMP}, \mathrm{KF}, \mathrm{AMC}, \mathrm{FOX}, \mathrm{CEC}$ \\
\hline F6VO & $\mathrm{S}, \mathrm{TE}, \mathrm{S3}$
\end{tabular}

${ }^{a} \mathrm{~S}$, estreptomicina; TE, tetraciclina; S3, "compound sulphonamides"; AMP, ampicilina; KF, cefalotina; C, cloranfenicol; AMC, amoxicilina - ácido clavulánico; FOX, cefoxitina; CEC, cefaclor.

Los antimicrobianos frente a los que se encontraron mayor resistencia fueron estreptomicina y sulfamidas, con un total de cinco cepas, seguidos por la ampicilina, con cuatro, y la tetraciclina y cefalotina con tres. Se encontraron además dos cepas resistentes al cloranfenicol y una a la amoxicilina-ácido clavulánico, a la cefoxitina y al cefaclor.

En todas ellas se investigaron los determinantes que conferían la resistencia a estos antimicrobianos (Tabla II.14). 
Tabla II.14. Resistencias a antimicrobianos y determinantes de la resistencia en nueve cepas de E. coli STEC no O157:H7.

\begin{tabular}{|c|c|c|c|c|c|c|c|c|c|}
\hline \multirow{2}{*}{ CEPA } & \multicolumn{9}{|c|}{ ANTIBIÓTICOS } \\
\hline & $\mathrm{AMP}^{\mathrm{a}}$ & $S$ & KF & TE & AMC & C & S3 & FOX & CEC \\
\hline M208VO & & strA/strB & & tetA & & & sul2 & & \\
\hline M279aVO & TEM-1b & strA/strB & & & & & sul2 & & \\
\hline M279bVO & TEM-1b & strA/strB & & & & & sul2 & & \\
\hline M298VO & Porinas & & Porinas & & & Porinas & & & \\
\hline M299VO & & & & & & Porinas & & & \\
\hline M329VO & & & Porinas & & & & & & \\
\hline F1VO & & strA/strB & & tet $B$ & & & sul2 & & \\
\hline F3VO & AmpCi. & & AmpCi. & & AmpCi. & & & AmpCi. & AmpC i. \\
\hline F6VO & & strA/strB & & tet $B$ & & & sul2 & & \\
\hline
\end{tabular}

\subsection{Electroforesis en Gel de Campo Pulsado (PFGE)}

El genotipado de las 62 cepas de E. coli STEC no-0157 dio lugar a 40 patrones de bandas. Con un porcentaje de similitud $\geq 72 \%$, las cepas se agruparon en cinco "clusters" o pulsotipos que se muestran en la Figura II.10, y cuyas características principales se resumen en la Tabla II.15.

- El pulsotipo I incluía 42 cepas de origen ovino, 35 aisladas de leche de tanque y siete de heces de oveja. Un total de 29 cepas obtenidas de leche mostraban pulsotipos idénticos que agrupaban entre dos y cinco cepas. Algunas procedían de la misma muestra de leche pero con distinto fenotipo; sin embargo, otras se habían aislado en diferentes explotaciones.

- El pulsotipo II estaba formado por siete cepas; dos de origen humano, dos de heces de ovino y tres de leche de tanque. Cuatro de ellas (tres de leche y una de heces de oveja) presentaban los mismos genes de virulencia.

- El pulsotipo III contenía cinco cepas, cuatro de leche y una clínica. Las cepas aisladas de leche presentaban un mismo perfil de genes de virulencia pero diferente perfil de resistencia a antimicrobianos. 
Capítulo II. Resultados

- El pulsotipo IV agrupaba cuatro cepas; tres de leche y una de agua.

- El pulsotipo $\mathbf{V}$ estaba formado por dos cepas aisladas de leche de tanque.

Las dos cepas restantes no pudieron ser incluidas en ningún "cluster"; una de ellas, (C180V0) procedía de un paciente y la otra (F3VO), que fue aislada de heces de ovino, era resistente a cinco antimicrobianos debido a la presencia de la $\beta$-lactamasa AmpC inducible. 


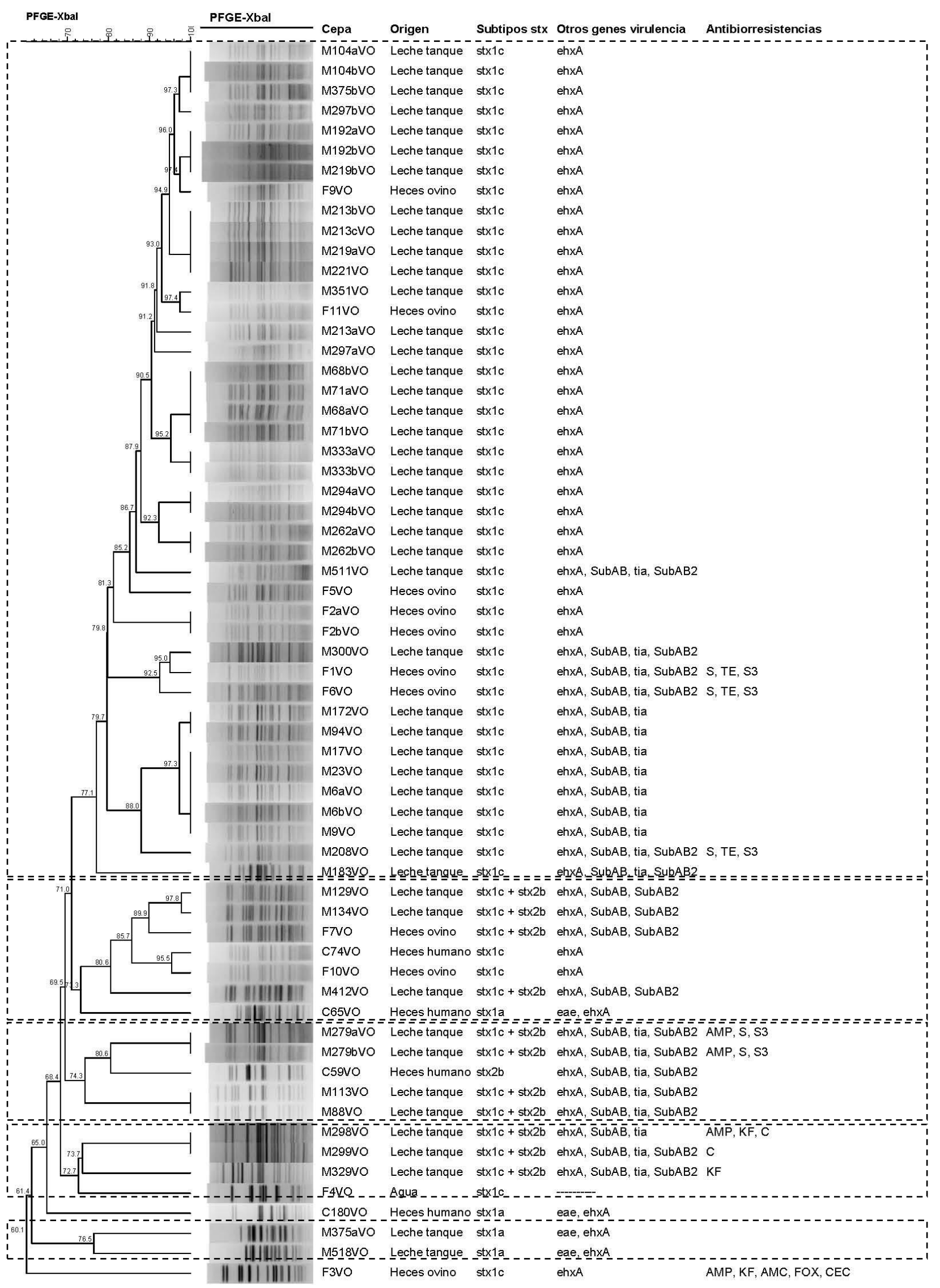

Figura II.10. Dendrograma Xbal-PFGE que muestra la relación genética entre las 62 cepas de $E$. coli STEC no-O157:H7 de origen ovino y humano. También proporciona información acerca de los subtipos de stxs y otros genes de virulencia. 
Tabla II.15. Características principales de las cepas STEC no-O157.

\begin{tabular}{|c|c|c|c|c|c|c|c|c|c|c|}
\hline Cepa & Origen & Explotación & Enriquecimiento & Lactosa & Sorbitol & Genes stx & Subtipos genes stx & Otros genes de virulencia & Serotipo & Pulsotipo \\
\hline M6aVo & Leche tanque & 13 & stx2 & + & - & stx1 & stx $1 \mathrm{c}$ & ehxA/SubAB/tia & & $\mathrm{I}$ \\
\hline M6bVO & Leche tanque & 13 & stx2 & + & + & stx1 & stx1c & ehxA/SubAB/tia & & 1 \\
\hline M9Vo & Leche tanque & 14 & stx2 & + & - & stx 1 & stx1c & ehxA/SubAB/tia & & 1 \\
\hline M17Vo & Leche tanque & 18 & stx 2 & + & - & stx1 & stx1c & ehxA/SubAB/tia & & 1 \\
\hline M23VO & Leche tanque & 22 & stx $1 /$ st $x 2$ & + & - & stx1 & stx1c & ehxA/SubAB/tia & & $\mathrm{I}$ \\
\hline M68aVo & Leche tanque & 64 & stx1/stx2 & + & - & stx1 & stx1c & $e h x A$ & & 1 \\
\hline M68bVO & Leche tanque & 64 & stx1/stx2 & - & - & stx1 & stx1c & $e h \times A$ & & $\mathrm{I}$ \\
\hline M71aVo & Leche tanque & 66 & stx $1 /$ stx 2 & + & - & stx1 & stx $1 \mathrm{c}$ & $e h \times A$ & & 1 \\
\hline M71bVO & Leche tanque & 66 & stx $1 /$ stx 2 & - & - & stx1 & stx1c & $e h \times A$ & & 1 \\
\hline M88VO & Leche tanque & 119 & stx 2 & + & + & stx $1 /$ st $x 2$ & stx $1 \mathrm{c} /$ st $x 2 \mathrm{~b}$ & ehxA/SubAB/tia/SubAB ${ }_{2}$ & $\mathrm{O} 146: \mathrm{H} 21$ & III \\
\hline M94VO & Leche tanque & 125 & stx1 & + & - & stx1 & stx1c & ehxA/SubAB/tia & & 1 \\
\hline M104aVo & Leche tanque & 145 & stx 2 & + & - & stx1 & stx1c & $e h x A$ & & 1 \\
\hline M104bVO & Leche tanque & 145 & stx2 & - & - & stx1 & stx1c & $e h \times A$ & & $\mathrm{I}$ \\
\hline M113VO & Leche tanque & 157 & stx2 & + & + & stx $1 /$ st $x 2$ & st $\times 1 \mathrm{c} /$ st $\times 2 \mathrm{~b}$ & ehxA/SubAB/tia/SubAB 2 & O146:H21 & III \\
\hline M129VO & Leche tanque & 224 & stx 1 & + & + & stx $1 /$ st $x 2$ & stx $1 \mathrm{c} /$ st $\times 2 \mathrm{~b}$ & $e h \times A / S u b A B / S u b A B_{2}$ & & II \\
\hline M134VO & Leche tanque & 227 & Negativo & + & + & stx $1 /$ stx 2 & stx $1 \mathrm{c} /$ stx $2 \mathrm{~b}$ & $e h \times A / S u b A B / S u b A B_{2}$ & & II \\
\hline M172VO & Leche tanque & 372 & Negativo & + & - & stx1 & stx1c & ehxA/SubAB/tia & & 1 \\
\hline M183VO & Leche tanque & 379 & stx1 & + & - & stx1 & stx $1 \mathrm{c}$ & ehxA/SubAB/tia/SubAB 2 & & $\mathrm{I}$ \\
\hline M192aVO & Leche tanque & 42 & stx 1 & + & - & stx 1 & stx $1 \mathrm{c}$ & $e h x A$ & & 1 \\
\hline M192bVO & Leche tanque & 42 & stx1 & - & - & stx1 & stx1c & $e h x A$ & & 1 \\
\hline M208VO & Leche tanque & 54 & stx $1 /$ st $x 2$ & - & - & stx1 & stx $1 \mathrm{c}$ & ehxA/SubAB/tia/SubAB ${ }_{2}$ & & 1 \\
\hline M213aVo & Leche tanque & 57 & stx1/stx2 & + & - & stx1 & stx1c & $e h x A$ & & $\mathrm{I}$ \\
\hline M213bVO & Leche tanque & 57 & stx1/stx2 & - & - & stx1 & stx1c & ehxA & & 1 \\
\hline $\mathrm{M} 213 \mathrm{cVO}$ & Leche tanque & 57 & stx1/stx2 & - & + & stx1 & stx1c & $e h \times A$ & & $\mathrm{I}$ \\
\hline M219aVo & Leche tanque & 70 & stx1 & + & - & stx 1 & stx1c & $e h \times A$ & & 1 \\
\hline M219bVO & Leche tanque & 70 & stx1 & - & - & stx1 & stx1c & $e h x A$ & & 1 \\
\hline M221VO & Leche tanque & 71 & stx $1 /$ stx 2 & - & - & stx1 & stx1c & $e h x A$ & & 1 \\
\hline M262aVO & Leche tanque & 111 & stx $1 /$ st $x 2$ & + & - & stx1 & stx1c & $e h \times A$ & & 1 \\
\hline M262bVO & Leche tanque & 111 & stx1/stx2 & - & - & stx1 & stx1c & $e h x A$ & & 1 \\
\hline M279aVO & Leche tanque & 161 & stx2 & + & - & stx $1 /$ st $x 2$ & stx $1 \mathrm{c} /$ st $\times 2 \mathrm{~b}$ & ehxA/SubAB/tia/SubAB 2 & & III \\
\hline M279bVO & Leche tanque & 161 & stx2 & - & - & stx $1 /$ stx 2 & stx $1 \mathrm{c} /$ st $\times 2 \mathrm{~b}$ & ehxA/SubAB/tia/SubAB ${ }_{2}$ & & III \\
\hline M294aVO & Leche tanque & 171 & stx1 & + & - & stx1 & stx1c & $e h x A$ & & 1 \\
\hline
\end{tabular}


Tabla II.15. (Continuación). Características principales de las cepas STEC no-0157.

\begin{tabular}{|c|c|c|c|c|c|c|c|c|c|c|}
\hline Cepa & Origen & Explotación & Enriquecimiento & Lactosa & Sorbitol & Genes stx & Subtipos genes stx & Otros genes de virulencia & Serotipo & Pulsotipo \\
\hline M294bVO & Leche tanque & 171 & stx1 & - & - & stx1 & stx1c & $e h x A$ & & $\mathrm{I}$ \\
\hline M297aVO & Leche tanque & 173 & stx $1 /$ st $x 2$ & + & - & stx1 & stx $1 \mathrm{c}$ & $e h x A$ & & 1 \\
\hline M297bVO & Leche tanque & 173 & stx $1 /$ st $x 2$ & - & - & stx 1 & stx $1 \mathrm{c}$ & $e h \times A$ & & $\mathrm{I}$ \\
\hline M298VO & Leche tanque & 173 & stx $1 /$ stx 2 & + & + & stx $1 /$ stx 2 & stx $1 \mathrm{c} /$ st $\times 2 \mathrm{~b}$ & ehxA/SubAB/tia & & IV \\
\hline M299VO & Leche tanque & 173 & st $x 1 / s t \times 2$ & + & + & st $x 1 /$ st $x 2$ & $s t \times 1 \mathrm{c} /$ st $\times 2 \mathrm{~b}$ & ehxA/SubAB/tia/SubAB $B_{2}$ & & IV \\
\hline M300VO & Leche tanque & 174 & Negativo & + & - & stx1 & stx $1 \mathrm{c}$ & ehxA/SubAB/tia/SubAB $B_{2}$ & & 1 \\
\hline M329VO & Leche tanque & 185 & stx2 & + & + & stx $1 /$ st $x 2$ & stx $1 \mathrm{c} / \mathrm{st} \times 2 \mathrm{~b}$ & ehxA/SubAB/tia/SubAB $B_{2}$ & & IV \\
\hline M333aVo & Leche tanque & 187 & stx2 & + & - & stx1 & stx $1 \mathrm{c}$ & $e h x A$ & & 1 \\
\hline M333bVO & Leche tanque & 187 & stx2 & - & - & stx1 & stx1c & $e h x A$ & & 1 \\
\hline M351VO & Leche tanque & 198 & stx $1 /$ st $x 2$ & - & - & stx 1 & stx $1 \mathrm{c}$ & $e h x A$ & & $\mathrm{I}$ \\
\hline M375aVo & Leche tanque & 217 & Negativo & + & + & stx1 & stx1a & eae/ehxA & & $\mathrm{V}$ \\
\hline M375bVO & Leche tanque & 217 & Negativo & - & - & stx 1 & stx1c & $e h x A$ & & 1 \\
\hline M412VO & Leche tanque & 245 & stx $1 /$ stx 2 & + & + & stx $1 /$ st $x 2$ & stx $1 \mathrm{c} /$ st $\times 2 \mathrm{~b}$ & $e h \times A / S u b A B / S u b A B_{2}$ & & II \\
\hline M511VO & Leche tanque & 356 & stx $1 /$ stx 2 & + & - & stx1 & stx1c & ehxA/SubAB/tia/SubAB $B_{2}$ & & 1 \\
\hline M518VO & Leche tanque & 359 & stx1 & + & + & stx1 & stx1a & eae, ehxA & & $\mathrm{V}$ \\
\hline F1VO & Heces ovino $(p)^{a}$ & 42 & stx 1 & + & - & stx1 & stx $1 \mathrm{c}$ & ehxA/SubAB/tia/SubAB 2 & & 1 \\
\hline F2aVO & Heces ovino $(p)$ & 64 & stx $1 /$ st $x 2$ & - & - & stx 1 & stx $1 \mathrm{c}$ & $e h x A$ & & 1 \\
\hline F2bVo & Heces ovino $(p)$ & 64 & stx $1 /$ st $x 2$ & - & + & stx1 & stx $1 \mathrm{c}$ & $e h x A$ & & 1 \\
\hline F3VO & Heces ovino (p) & 173 & stx $1 /$ stx 2 & + & + & stx1 & stx $1 \mathrm{c}$ & $e h x A$ & & $N A^{c}$ \\
\hline F4VO & Agua (p) & 71 & stx $1 /$ stx 2 & + & + & stx1 & stx1c & & & IV \\
\hline F5VO & Heces ovino $(p)$ & 187 & stx2 & - & - & stx1 & stx $1 \mathrm{c}$ & $e h x A$ & & 1 \\
\hline F6VO & Heces ovino $(v)^{b}$ & 42 & stx1 & + & - & stx1 & stx1c & ehxA/SubAB/tia/SubAB 2 & & $\mathrm{I}$ \\
\hline F7VO & Heces ovino (v) & 42 & stx1 & + & + & stx $1 /$ st $x 2$ & st $\times 1 \mathrm{c} /$ st $\times 2 \mathrm{~b}$ & $e h \times A / S u b A B / S u b A B_{2}$ & & II \\
\hline F9VO & Heces ovino (v) & 57 & stx $1 /$ stx 2 & - & - & stx1 & stx1c & $e h x A$ & & $\mathrm{I}$ \\
\hline F10VO & Heces ovino (v) & 64 & stx $1 /$ st $x 2$ & - & - & stx 1 & stx $1 \mathrm{c}$ & $e h x A$ & & II \\
\hline F11Vo & Heces ovino (v) & 173 & stx $1 /$ st $x 2$ & - & - & stx 1 & stx $1 \mathrm{c}$ & $e h x A$ & & 1 \\
\hline C59Vo & Heces humano & & & + & + & stx2 & $s t \times 2 b$ & ehxA/SubAB/tia/SubAB $B_{2}$ & O146:H21 & III \\
\hline C65VO & Heces humano & & & + & + & stx1 & stx1a & $e a e, e h x A$ & $\mathrm{O} 26: \mathrm{H} 11$ & II \\
\hline C74VO & Heces humano & & & - & - & stx1 & stx1c & $e h x A$ & O176:H- & II \\
\hline C180VO & Heces humano & & & + & + & stx1 & stx1a & eae,ehxA & O98:H- & NA \\
\hline
\end{tabular}

${ }^{a}(p)$ muestreo de primavera/ ${ }^{b}(v)$ muestreo de verano/ ${ }^{c} \mathrm{NA}$ : Cepa no agrupada en ningún "cluster". 


\section{DISCUSIÓN}

\section{CARACTERIZACIÓN DE CEPAS DE E. coli STEC}

El aislamiento e identificación de cepas de E. coli a partir de alimentos y otras muestras es un proceso sencillo que incluye la siembra en medios conteniendo lactosa y su posterior caracterización bioquímica, utilizando técnicas convencionales o sistemas comerciales como las galerías $\mathrm{Api}^{\circledR}$ 20E (BioMerieux). Sin embargo, los fenotipos de las cepas pertenecientes a los grupos patógenos de interés como agentes de infecciones alimentarias, presentan variaciones en relación con la cepa tipo de esta especie (Elizaquível et al., 2011). Por tanto, no es extraño que las galerías $\mathrm{Api}^{\circledR} 20 \mathrm{E}$ utilizadas adscribieran nueve de nuestras cepas, aisladas de leche de tanque, a géneros y especies de bacterias Gram-negativas diferentes de $E$. coli. Teniendo en cuenta los resultados obtenidos con las 50 cepas de leche de oveja, se consideró que no era de interés la caracterización bioquímica de las otras 30 cepas incluidas en este Capítulo (12 obtenidas del "medio ambiente" de las explotaciones y 18 procedentes de muestras clínicas).

En el caso del Dryspot E. coli 0157 test (Oxoid), éste fue útil para la detección de cepas de E. coli O157, ya que las cuatro, de origen ovino, que fueron positivas en esta prueba, se confirmaron posteriormente con el antisuero del "Stanten Serum Institut" y, además, poseían el gen que codifica para el antígeno somático 0157 (O157rfbE).

\section{CEPAS DE E. coli 0157:H7}

El fenotipo de las 18 cepas de E. coli O157:H7 (14 clínicas, tres de leche y una de agua) era típico ya que todas ellas fermentaban la lactosa, no fermentaban el sorbitol, carecían de actividad $\beta$-glucuronidasa y producían enterohemolisina, confirmada por la presencia del gen que codifica para ésta (exhA). Poseían también otros genes asociados con este serotipo como son los que codifican para las toxinas Shiga, los que codifican para los antígenos somáticos 0157 (O157rfbE) y flagelar H7 (fliCh7), el que codifica para la intimina (eae) y su variante eaev1 y el plásmido p0157 (Pcvd419) (Paton \& Paton, 1998; Gyles, 2007). 
En cuanto a los genes que codifican para las toxinas Stxs, todas las cepas poseían el gen stx2. La mayoría, incluidas las cuatro obtenidas de explotaciones ovinas, albergaban únicamente este gen y ninguna poseía sólo el gen que codifica para la toxina Stx1. Esto coincide con los resultados obtenidos en otros trabajos en los que se caracterizaron cepas de E. coli 0157:H7 de origen ovino y humano (Heuvelink et al., 1998; Chapman et al., 2001; Blanco et al., 2003; Rey et al., 2003; Mora et al., 2004; Caro et al., 2006; Oporto et al., 2008).

Considerando los subtipos de los genes stxs, las cuatro cepas de origen ovino (pulsotipo II, Figura II.8) y nueve de origen humano (cuatro de ellas también agrupadas en el pulsotipo II) mostraban el subtipo stx2c. Este subtipo acompañado del stx1a se detectó en cuatro cepas humanas (pulsotipo I), presentando una de ellas, además, el subtipo stx2a. La cepa clínica restante era stx1a+/stx2a+. Desde el punto de vista clínico, el perfil genético stx2 en cepas de E. coli $0157: \mathrm{H7}$, especialmente si va acompañado del gen eae, tiene mayor probabilidad de producir SUH que las que presentan el gen que codifica para la toxina Stx1 o las que producen ambas toxinas. De hecho, los subtipos stx2a, stx2c y stx2d son los asociados más frecuentemente con procesos humanos graves (Gyles, 2007; Bergan et al., 2012; Farrokh et al., 2013).

Por lo que respecta a la fagotipia, las cepas de origen ovino y tres cepas clínicas pertenecían al fagotipo 54. El resto pertenecían a los fagotipos 8, 14, 32, 34, 70 y 71prov, presentando una de ellas un patrón de lisis no reconocible (PNR). En trabajos similares realizados en nuestro país, el fagotipo 54 se detectó con frecuencia en cepas de origen ovino (Rey et al., 2003; Mora et al., 2004) aunque entre las aisladas en otras áreas geográficas (Holanda y Reino Unido), su presencia era muy escasa e incluso inexistente (Heuvelink et al., 1998; Chapman et al., 2001). Los fagotipos de las cepas clínicas coincidieron, en general, con los hallados en otros estudios (Heuvelink et al., 1998; Chapman et al., 2001; Mora et al., 2004). Las cepas del fagotipo 54 presentaban el mismo perfil de genes stxs (stx2c) aunque no pertenecían al mismo pulsotipo (las cepas de origen ovino se agrupaban dentro del pulsotipo II y las de origen humano constituían el III). Esto confirma que, como para otras bacterias; por ejemplo, Staphyloccus aureus, el fagotipado tiene menor capacidad de discriminación que la técnica PFGE aunque la combinación de ambos métodos se considera complementaria 
y adecuada tanto para la subtipificación de cepas de E. coli 0157:H7 como para determinar el reservorio de las cepas (Mora et al., 2004). Algunos fagotipos de cepas st $x 2+$ y st $x 2 c+$ como el $21 / 28$, el 2 y el 8 se asocian, al menos en el Reino Unido e Irlanda, con el desarrollo de SUH en pacientes, ocupando las cepas del fagotipo 8 el segundo lugar entre los casos declarados en Inglaterra y Gales (EFSA, 2007). En este estudio tres de las cuatro cepas clínicas del pulsotipo I (Figura II.8) eran stx2c+ y pertenecían al fagotipo 8.

En cuanto a la resistencia a los antimicrobianos, únicamente cepas clínicas (siete) fueron resistentes a uno o más de los compuestos ensayados, lo que sugiere que los pacientes habían recibido algún tipo de tratamiento previo. Hay que resaltar que tres de ellas eran multirresistentes. Este porcentaje $(38,9 \%)$ es superior al obtenido en estudios similares (Meng et al., 2013).

Por lo que respecta a los determinantes que conferían la resistencia (Tabla II.10), hay que señalar lo siguiente: para las tres cepas resistentes a la estreptomicina, en dos de ellas (3697/10 y 4594/10) se detectó un integrón de clase I conteniendo la casete genética de resistencia a antibióticos con los genes aadA1 (confieren resistencia a la estreptomicina) y $d f r A 1$ (resistencia al trimetoprim sulfametoxazol). Además estos integrones de clase I poseen en el extremo $3^{\prime}$ un segmento conservado ( $3^{\prime} \mathrm{CS}$ ) que incluye el gen sul1 que confiere resistencia a sulfamidas (Levesque et al., 1995). En la cepa restante $(3643 / 11)$ se detectaron los genes strA y strB que codifican para fosfotransferasas que fosforilan aminoglicósidos confiriendo así la resistencia a este antibiótico. Las cepas resistentes al ácido nalidíxico lo fueron debido a la presencia de una mutación en el gen que codifica para la subunidad A de la ADN-girasa (gyrA). Esta enzima constituye la diana primaria de las quinolonas, entre las que se encuentra el ácido nalidíxico. Las dos cepas presentaban una mutación en un aminoácido presente en la denominada "Quinolone resistance determinant región" (QRDR) del gen gyrA, que en el caso de E. coli va del codón 67 al 106 (Griggs et al., 1996). La mutación presente en ambas cepas fue la misma, Ser83 $\rightarrow$ Leu. La resistencia a la tetraciclina fue debida, en todos los casos, a la presencia del gen tetA. Este gen codifica para una proteína que constituye una bomba de expulsión de tetraciclinas asociada a la membrana. La resistencia al cloranfenicol de la cepa 3697/10 era debida a una 
inactivación enzimática del antibiótico por la presencia del gen CatA1 que codifica para una cloranfenicol acetil transferasa. Finalmente, la resistencia a sulfamidas se debió, en la cepa 3643/11, a la presencia del gen sul2, que en muchos casos precede a los genes strA y strB presentes también en esta cepa (Bean et al., 2009). En las cepas $3697 / 10$ y 4594/10, como ya se ha señalado, la resistencia se debió a la presencia del gen sul1 asociado al integrón de clase I. Los genes sul1 y sul2 codifican formas resistentes de la dihidropteroico sintetasa.

De los tres "clusters" o pulsotipos hallados al aplicar la técnica PFGE, dos (I y III) estaban integrados exclusivamente por cepas clínicas, algunas idénticas, pero en el II se agruparon las cuatro cepas de origen ovino junto con cuatro de las cepas aisladas de pacientes, mostrando todas ellas el mismo patrón de genes stxs (stx2c). Dentro de este pulsotipo, dos cepas clínicas presentaban un $90,1 \%$ de similitud con las cepas de origen ovino. Esta similitud entre cepas de origen humano y cepas procedentes de rumiantes ha sido observada por otros autores (Mora et al., 2004) y confirma que estos animales pueden ser un reservorio de cepas de E. coli O157:H7.

La presencia de cepas de E. coli 0157:H7 en muestras de heces de animales lecheros como es el ganado ovino es bastante frecuente (Blanco et al., 2003; Rey et al., 2003; Sánchez et al., 2009) pero, aunque la incidencia de los genes stx1 y stx2 en muestras de leche es alta, el aislamiento de cepas 0157 de este alimento suele ser muy bajo (Farrokh et al., 2013). En este estudio, la presencia de una cepa de E. coli 0157:H7 en el agua de bebida del ganado es motivo de preocupación, ya que se ha comprobado que en una explotación, el agua de bebida contaminada con E. coli 0157:H7 puede ser un reservorio de esta bacteria y la causa de diseminación dentro del rebaño (LeJeune et al., 2001; Berry \& Wells, 2010).

En resumen, las similitudes halladas entre las cepas de E. coli 0157:H7 de origen ovino y algunas de origen humano, tanto en el perfil de bandas obtenido con la técnica PFGE como en el fagotipo, confirma que los animales de la especie ovina constituyen un reservorio de E. coli $\mathrm{O} 157: \mathrm{H} 7$ y que su leche y productos derivados no tratados térmicamente pueden suponer un riesgo en relación con esta bacteria. 


\section{CEPAS DE E. coli STEC NO-0157}

Las cepas de E. coli pertenecientes al serogrupo 0157 han sido estudiadas exhaustivamente pero se ha prestado mucha menos atención a las cepas STEC no0157. De hecho, no parece posible definir de forma adecuada a este último grupo de bacterias ya que se han aislado cepas STEC no-O157 pertenecientes a cientos de serovariedades. Además, presentan diferencias notables tanto en el fenotipo como en su patogenicidad (Bettelheim, 2007). En nuestras cepas se han apreciado distintos fenotipos ya que, por ejemplo, unas fermentaban el sorbitol y otras no, sucediendo lo mismo con la capacidad de fermentar la lactosa. Tenían en común, la presencia de genes stxs y del gen que codifica para la enterohemolisina (exhA).

En cuanto a los genes que codifican para las toxinas Stxs (Figura II.9, Tablas II.11 y II.15), en todas las cepas, salvo una, se detectó el gen stx1 sólo $(80,7 \%)$ o acompañado del gen stx2 $(17,7 \%)$. La cepa restante $(1,6 \%)$ poseía únicamente el gen stx2. Estos datos coinciden con los obtenidos en otros estudios realizados con poblaciones de STEC no-0157 de origen ovino en los que la mayor incidencia también correspondía a cepas stx1+ y stx1+/stx2+ (Blanco et al., 2003; Oporto et al., 2008). En nuestro caso, resulta evidente la diferencia entre las cepas de E. coli STEC no-O157 y las 0157:H7 ya que estas últimas albergaban todas ellas el gen stx2. Considerando los subtipos de los genes stxs, el encontrado con mayor frecuencia entre las cepas no0157 stx $1+$ fue el stx1c y entre las cepas stx2+, únicamente se detectó el stx2b. Ambos subtipos han sido descritos frecuentemente en cepas STEC procedentes de pequeños rumiantes y también de ciervos (Beutin et al., 2007; Martin \& Beutin, 2011). La importancia clínica de las cepas stx2+ es superior tanto a la de las cepas stx1+ como a la de las cepas stx $1+/$ st $x 2+$ ya que la probabilidad de que las primeras puedan inducir la aparición del síndrome SUH es más alta. Además, como ya se ha indicado, los subtipos stx2a, stx2c y stx2d son los que parecen presentar un riesgo mayor como agentes de procesos clínicos graves (EFSA, 2007; Farrokh et al., 2013).

Las Figuras II.9 y II.10 junto con la Tabla II.15 muestran que todas las cepas de E. coli STEC no-0157, excepto una, eran portadoras del gen exhA (enterohemolisina). Este dato también coincide con otros procedentes de estudios previos en los que el 
porcentaje de cepas STEC ovinas que presentaban este gen era elevado (Zschöck et al., 2000; Djordjevic et al., 2001; Djordjevic et al., 2004; Bhat et al., 2008; Vettorato et al., 2009).

El gen que codifica para la intimina (eae) se encontró en cuatro cepas que también presentaban los genes stx1a y exhA. Dos de ellas (M375aVO y M518VO) procedían de muestras de leche de tanque y las otras dos (C65VO y C180VO) de pacientes. Las dos cepas aisladas de leche formaban el pulsotipo V (Figura II.10). Una de las cepas clínicas (C180VO) no pertenecía a ningún "cluster" (Figura II.10) y presentaba el serotipo 098:H- mientras que la cuarta cepa (C65VO), también de origen humano, se agrupaba con cepas ovinas y otra clínica en el pulsotipo II (Figura II.10). La cepa C65VO pertenecía al serotipo 026:H11 (Tabla II.15) que produce procesos graves y brotes similares a los ocasionados por cepas del serogrupo 0157 (Gyles, 2007). Las cepas del serotipo 026:H11 suelen ser, como en nuestro caso, portadoras del gen stx1 pero cepas 026:H11 stx1+/stx2+ o stx2+ están empezando a ser implicadas en infecciones y SUH (EFSA, 2007). Teniendo en cuenta que el gen eae es considerado un posible marcador de virulencia (Farrokh et al., 2013) y que dos de las cepas eae+ eran clínicas y mostraban idéntico perfil de genes que las aisladas de leche, podría ser que estas últimas (M375aVO y M518VO) fueran también potencialmente patógenas.

Considerando en su conjunto los genes de virulencia discutidos hasta ahora, el patrón dominante correspondía a los stx1 (principalmente el subtipo stx1c) y exhA. Este perfil ha sido mayoritariamente hallado en cepas STEC procedentes de ovino aisladas y caracterizadas por algunos investigadores (Zschöck et al., 2000; Djordjevic et al., 2001; Zweifel et al., 2004) aunque en otras poblaciones de cepas ovinas, el perfil mayoritario de los genes encontrados estaba formado por stx1, stx2 y hlyA (Rey et al., 2003; Vettorato et al., 2003; Djordjevic et al., 2004; Bhat et al., 2008; Vettorato et al., 2009).

La subtilasa (SubAB) es una citotoxina producida por algunas cepas de STEC que, generalmente, carecen de la isla de patogenicidad LEE. Se han descrito dos variantes de los genes $s u b A B$, la presente en el plásmido p0113 denominada $s u b A B_{1}$ que aparece junto con el gen saa (codifica para una adhesina autoaglutinante) y la 
localizada en una isla de patogenicidad ("SE-PAI"), junto con el gen tia (codifica para un factor de invasión descrito en ETEC), denominada $\operatorname{subAB}_{2}$ (Michelacci et al., 2013). Entre nuestras cepas (Tabla II.12 y II.15), 25 (40,3\%) poseían el gen $\operatorname{subAB,~} 21$ de ellas el gen tia y ninguna de las de este grupo el gen que codifica para la intimina (eae) que está presente en la isla de patogenicidad LEE. Diecisiete de las cepas subAB+ presentaban la variante alélica $\operatorname{SubAB_{2}}, 13$ de ellas junto con el gen tia. Se ha sugerido que las cepas LEE- "SE-PAI" + han surgido de una exclusión mutua de las islas de patogenicidad LEE y "SE-PAI" que podrían competir por el mismo lugar de integración. Esta hipótesis explicaría la presencia del operón $s u b A B_{2}$ en las cepas LEE- y su aparente ausencia en las LEE+ (Michelacci et al., 2013). Orden et al. (2011) investigaron el gen sUbAB y los genes saa y tia en cepas de E. coli STEC procedentes de pequeños rumiantes. Un $91,9 \%$ de las cepas resultaron positivas para el gen $S u b A B$ y la mayoría presentaron además el gen tia. En nuestro estudio, ocho de las cepas subAB+ no presentó ninguna de las dos variantes alélicas, lo que podría explicarse por la sugerencia previa de que, probablemente, existen más variantes alélicas de este gen (Michelacci et al., 2013).

En la cepa clínica C59VO (pulsotipo III, Figura II.10) que mostraba el perfil st $\times 2 b+/ e h \times A+y$ pertenecía al serotipo 0146:H21 se detectaron también los genes $s u b A B, s u b A B_{2}$ y tia (Tabla II.15). Además de los factores de virulencia regulados por los genes stxs, eae y otros, la producción de la citotoxina SubAB podría contribuir a la patogenicidad de las cepas de E. coli STEC eae- (Orden et al., 2011).

Considerando la resistencia a los antimicrobianos ensayados, nueve cepas $(14,5 \%)$, aisladas de muestras de leche de tanque y de heces de oveja procedentes de cinco explotaciones diferentes, mostraron resistencia a uno o más de los siguientes compuestos: estreptomicina (S), sulfamidas (S3), ampicilina (AMP), tetraciclina (TE), cefalotina (KF), cloranfenicol (C), amoxicilina-ácido clavulánico (AMC), cefoxitina (FOX) y cefaclor (CEC) (Tabla II. 13). Los antimicrobianos frente a los que se encontró mayor resistencia fueron la estreptomicina y las sulfamidas, seguidos de ampicilina, tetraciclina y cefalotina. En otros estudios realizados con cepas procedentes de diferentes especies animales, entre ellas ovino, se observó una resistencia elevada frente a tetraciclina, ampicilina y estreptomicina aunque también era significativa 
frente a sulfamidas, cefalotina y cloranfenicol (Khan et al., 2002; Mora et al., 2005; Karczmarczyk et al., 2011).

El uso de antibióticos de un grupo puede producir resistencias a otros del mismo grupo/generación y a los de generaciones anteriores (siempre que posean el mismo mecanismo de acción), por lo que el patrón de resistencia detectado en estas cepas de origen ovino podría estar relacionado con los medicamentos veterinarios utilizados en sanidad animal para prevenir y/o tratar las mamitis y otras patologías. Durante el secado, se utilizan dos terapias para la prevención de las mamitis:

- Cefaxam (Laboratorios Syva S.A.U., León), 383 g de Cefapirina-benzatina. Éste producto incluye una cefalosporina de primera generación (cefapirna) y una penicilina (benzatina) que actúa inhibiendo la síntesis y reparación de la pared bacteriana.

- Mamyzin secado (Boehringer-Ingelheim España S.A., Barcelona), 100 mg de penetamato iohidrato, $280 \mathrm{mg}$ de benetamina penicilina y $100 \mathrm{mg}$ de framicetina sulfato. Este fármaco contiene por tanto penicilinas (penetamato iohidrato -que da lugar a la liberación de una bencilpenicilina- y benetamina penicilina) y un aminoglucósido (framicetina sulfato).

En el caso de mamitis clínica y agalaxia contagiosa (Mycoplasma agalactiae) se utilizan espiramicina (macrólido), enrofloxacina (quinolona) y penicilina. En época de paridera se suele emplear además doxiciclina (tetraciclina) para la prevención de abortos; y en caso de pedero se utiliza oxitetraciclina (tetraciclina).

Por tanto, el uso de estos y otros tratamientos podrían explicar la aparición de resistencias a antimicrobianos en nuestras cepas.

Entre nuestras cepas, se detectaron cinco resistentes a la estreptomicina que lo fueron también a las sulfamidas, ya que los genes que les conferían esta resistencia eran el strA y el strB (Tabla II.14) que, como ya se ha dicho, normalmente se encuentran precedidos por el gen sul2 que confiere resistencia a las sulfamidas (Bean et al., 2009). 
Una cepa de leche (M208VO) y dos de heces (F1VO y F6VO) eran resistentes a la estreptomicina, la tetraciclina y las sulfamidas. La causa de la resistencia a la estreptomicina y a las sulfamidas ya se ha discutido. En el caso de la tetraciclina la resistencia se debió a la presencia de "bombas de expulsión de tetraciclinas" (tetA o tetB) (Tabla II.14).

Dos cepas aisladas de leche (M279aVO y M279bVO) eran resistentes a la ampicilina, la estreptomicina y las sulfamidas. La causa de las dos últimas resistencias se ha comentado reiteradamente. El determinante de la resistencia a la ampicilina era el gen TEM, la secuenciación de este gen demostró la presencia de la $\beta$-lactamasa TEM-1b (Tabla II.14).

La cepa de leche M298VO mostraba resistencia a la ampicilina, la cefalotina y al cloranfenicol. La resistencia al cloranfenicol en las cepas M298VO y M299VO es llamativa ya que se trata de un medicamento que, en la Unión Europea, está incluido en la lista de sustancias prohibidas para uso veterinario desde el año 1990 y actualmente en el Reglamento UE 37/2010 (Anónimo, 2010). Nuestros datos (Tabla II.14) sugieren que las resistencias de las cepas M298VO, M299VO y M329VO podrían deberse a alteraciones en la membrana celular. La membrana externa de las bacterias Gram-negativas es una barrera frente a moléculas polares. Las porinas, que facilitan el paso de pequeños nutrientes polares, son la principal vía de entrada de muchos antibióticos ( $\beta$-lactámicos, tetraciclina, cloranfenicol, fluoroquinolonas y cefalosporinas) (Harder et al., 1981; Nikaido, 2003; Tenover, 2006; Lou et al., 2011). La resistencia a antimicrobianos ha sido relacionada con la alteración de la expresión de porinas o su función restringida debido a mutaciones puntuales. E. coli produce principalmente dos porinas (OmpC y $\mathrm{OmpF}$ ) que se expresan en ambientes con alta osmolaridad como el intestino humano. Muchas cepas de E. coli resistentes han disminuido o eliminado la expresión de la OmpF lo que evidencia que esta porina es la principal vía de entrada de antibióticos. Más recientemente se ha sugerido que el papel de la OmpC en la resistencia a antibióticos podría estar subestimado, ya que mutaciones en esta porina han sido detectadas en cepas resistentes (Harder et al., 1981; Nikaido, 2003; Pagès et al., 2008; Lou et al., 2011). 
Finalmente, una cepa aislada de heces ovinas, la F3VO, era resistente a cinco antimicrobianos: ampicilina, amoxicilina-ácido clavulánico, cefalotina, cefoxitina y cefaclor. La resistencia de la cepa F3VO a todos estos compuestos estaría relacionada con la presencia de la $\beta$-lactamasa AmpC cromosómica inducible (Tabla II.14) que explicaría la resistencia a aminopenicilinas, cefalosporinas de primera generación, cefamicinas (cefoxitina, cefotetán) y aminopenicilinas combinadas con inhibidores de ß-lactamasas como amoxicilina-ácido clavulánico (Del Valle Martínez, 2011).

Con los datos obtenidos en este trabajo, se puede concluir que la incidencia de resistencia a antimicrobianos entre las cepas no-0157 era inferior a la observada entre las cepas 0157. Esto no coincide con estudios previos, que observaron que el porcentaje de cepas no-0157 resistentes era superior al de las cepas 0157. Sin embargo, sí que coincide con el hecho de que los perfiles de resistencia correspondían mayoritariamente a determinados compuestos como estreptomicina y sulfamidas (Tablas II.9 y II.13) (Meng et al., 2013). La presencia y diseminación de cepas STEC resistentes o multirresistentes en alimentos es preocupante.

Por lo que respecta al genotipado de la población no-0157, el análisis del dendrograma presentado en la Figura II. 10, muestra que, utilizando la técnica PFGE, la mayoría de las cepas de leche de tanque (35 de 47) y de las obtenidas de heces de oveja (siete de 10) se agruparon en el "cluster" I. Todas ellas presentaban el genotipo stx1c+/ehxA+ y 13 eran, además, subAB+. Este pulsotipo contenía subgrupos con cepas idénticas o muy semejantes que, a veces, procedían de la misma explotación (con distinto fenotipo) pero también de diferentes rebaños. Esto último podría explicarse por el posible intercambio de ganado entre las diferentes explotaciones que integran el Consorcio.

El "cluster" II estaba formado por cepas de todos los orígenes, salvo de agua de bebida, destacando la presencia de dos de las cepas clínicas. Una de ellas, la cepa C74VO mostraba una similitud superior al 95\% con otra obtenida de heces de oveja (F10VO), siendo ambas stx1c+/ehxA+. El “cluster" III también contenía otra cepa clínica (C59VO) que mostraba una similitud del $80,6 \%$ con dos cepas de leche (M279aVO y M279bVO). La cepa humana C59VO era stx2b+/exhA+/subAB+/tia+/subAB 2 y las de 
leche $s t \times 1 \mathrm{c}+/ s t \times 2 \mathrm{~b}+/ e x h A+/ s u b A B+/ t i a+/ s u b A B_{2}$. La cepa clínica restante (C180VO) era stx1a+/eae+/ehxA+ y no se agrupó en ningún "cluster".

El "cluster" IV incluía cepas de leche y una de agua de bebida. Todas ellas poseían el gen stx1c. La presencia de una cepa de E. coli STEC no-0157 en el agua de bebida de una explotación supone, como en el caso de la cepa 0157:H7, un riesgo por su posible diseminación en el rebaño. El quinto "cluster" estaba constituido sólo por dos cepas de leche con el mismo genotipo stx1a+/eae+/ehxA+.

En cuanto al origen de la contaminación de la leche, se han propuesto dos posibilidades; una, poco frecuente, serían las mamitis subclínicas por cepas STEC y la otra, más probable, la contaminación con heces tanto directa como indirectamente. Se considera que un número considerable de animales lecheros albergan cepas STEC en su intestino. Las heces de estos animales contaminarían la ubre y de ahí pasarían a la leche durante el ordeño. Además, estas cepas podrían permanecer viables en las ordeñadoras y en otros equipos y utensilios de la explotación si éstos no están bien diseñados y no se limpian y desinfectan correctamente. Por lo tanto, el mantenimiento de animales limpios y la higiene adecuada durante el ordeño son factores clave para minimizar la presencia de cepas STEC en la leche durante la producción primaria. Para ganado vacuno y cepas 0157:H7 se han propuesto medidas adicionales como son la detección de animales portadores, el empleo de probióticos, la utilización de vacunas, etc. (Farrokh et al., 2013).

En resumen, la leche de oveja, las heces de estos animales y el agua de bebida contienen frecuentemente cepas de E. coli STEC no-0157, siendo algunas de ellas semejantes a las obtenidas de coprocultivos de pacientes.

La conclusión general del trabajo recogido en este Capítulo es la siguiente: en la leche de oveja y en el medio ambiente de las explotaciones ovinas se detectan frecuentemente cepas de E. coli productoras de toxinas Shiga. Como era de esperar, la incidencia de cepas 0157:H7 es menor que la de las cepas no-0157. Sin embargo, todas poseían genes marcadores de virulencia, siendo algunas de ellas resistentes a uno o varios agentes antimicrobianos. La comparación, mediante PFGE, de ambos grupos con cepas clínicas detectó similitudes. Nuestros datos confirman que la leche 
Capítulo II. Discusión

de oveja y la propia explotación, especialmente el agua de bebida, son un reservorio de estas bacterias. 
Capítulo II. Bibliografía

\section{BIBLIOGRAFÍA}

1. Anónimo. 2010. Reglamento (UE) № 37/2010 de la Comisión de 22 de diciembre de 2009 relativo a las sustancias farmacológicamente activas y su clasificación por lo que se refiere a los límites máximos de residuos en los productos alimenticios de origen animal. D. O., L 15: 1-72.

2. Bean, D. C., Livermore, D. M. and Hall, L. M. C. 2009. Plasmids imparting sulfonamide resistance in Escherichia coli: implications for persistence. Antimicrob. Agents Chemother., 53: 1088-1093.

3. Bergan, J., Dyve Lingelem, A. B., Simm, R., Skotland, T. and Sandvig, K. 2012. Shiga toxins. Toxicon, 60: 1085-1107.

4. Berry, E. D. \& Wells, J. E. 2010. Escherichia coli O157: H7: recent advances in research on occurrence, transmission, and control in cattle and the production environment. Adv. Food Nutr. Res., 60: 67-117.

5. Bettelheim, K. A. 2007. The non-0157 Shiga-toxigenic (verocytotoxigenic) Escherichia coli; under-rated pathogens. Crit. Rev. Microbiol., 33: 67-87.

6. Beutin, L., Miko, A., Krause, G., Pries, K., Haby, S., Steege, K. and Albrecht, N. 2007. Identification of human-pathogenic strains of Shiga toxin-producing Escherichia coli from food by a combination of serotyping and molecular typing of Shiga toxin genes. Appl. Environ. Microbiol., 73: 4769-4775. 
7. Bhat, M. A., Nishikawa, Y. and Wani, S. A. 2008. Prevalence and virulence gene profiles of Shiga toxin-producing Escherichia coli and enteropathogenic Escherichia coli from diarrhoeic and healthy lambs in India. Small Ruminant Res., 75: 65-70.

8. Blanco, M., Blanco, J. E., Mora, A., Rey, J., Alonso, J. M., Hermoso, M., Hermoso, J., Alonso, M. P., Dahbi, G. and González, E. A. 2003. Serotypes, virulence genes, and intimin types of Shiga toxin (verotoxin)-producing Escherichia coli isolates from healthy sheep in Spain. J. Clin. Microbiol., 41: 1351-1356.

9. Bugarel, M., Beutin, L., Martin, A., Gill, A. and Fach, P. 2010. Micro-array for the identification of Shiga toxin-producing Escherichia coli (STEC) seropathotypes associated with Hemorrhagic Colitis and Hemolytic Uremic Syndrome in humans. Int. J. Food Microbiol., 142: 318-329.

10. Caro, I., Fernández-Barata, V. M., Alonso-Llamazares, A. and García-Armesto, M. R. 2006. Detection, occurrence, and characterization of Escherichia coli O157:H7 from raw ewe's milk in Spain. J. Food Prot., 69: 920-924.

11. Chapman, P. A., Cerdan Malo, A. T., Ellin, M., Ashton, R. and Harkin, M. A. 2001. Escherichia coli $\mathrm{O} 157$ in cattle and sheep at slaughter, on beef and lamb carcasses and in raw beef and lamb products in South Yorkshire, UK. Int. J. Food Microbiol., 64: 139150.

12. Chu, C., Chiu, C. H., Wu, W. Y., Chu, C. H., Liu, T. P. and Ou, J. T. 2001. Large drug resistance virulence plasmids of clinical isolates of Salmonella enterica serovar Choleraesuis. Antimicrob. Agents Chemother., 45: 2299-2303. 
Capítulo II. Bibliografía

13. Clinical and Laboratory Standards Institute. 2005. Performance standards for antimicrobial susceptibility testing. Fifteenth informational supplement, 25 nำ M100S15.

14. Del Valle Martínez, D. 2011. Betalactamasas tipo AmpC: generalidades y métodos para detección fenotípica. Revista de la Sociedad Venezolana de Microbiología, 29: 7883.

15. Desmarchelier, P. M., Bilge, S. S., Fegan, N., Mills, L., Vary Jr, J. C. and Tarr, P. I. 1998. A PCR specific for Escherichia coli 0157 based on the rfb locus encoding 0157 lipopolysaccharide. J. Clin. Microbiol., 36: 1801-1804.

16. Djordjevic, S. P., Ramachandran, V., Bettelheim, K. A., Vanselow, B. A., Holst, P., Bailey, G. and Hornitzky, M. A. 2004. Serotypes and virulence gene profiles of Shiga toxin-producing Escherichia coli strains isolated from feces of pasture-fed and lot-fed sheep. Appl. Environ. Microbiol., 70: 3910-3917.

17. Djordjevic, S. P., Hornitzky, M. A., Bailey, G., Gill, P., Vanselow, B., Walker, K. and Bettelheim, K. A. 2001. Virulence properties and serotypes of Shiga toxin-producing Escherichia coli from healthy Australian slaughter-age sheep. J. Clin. Microbiol., 39: 2017-2021.

18. EFSA. 2011. Shiga toxin-producing E. coli (STEC) O104:H4 2011 outbreaks in Europe: Taking Stock. EFSA Journal, 9: 2390.

19. EFSA. 2007. Monitoring of verotoxigenic Escherichia coli (VTEC) and identification of human pathogenic VTEC types. EFSA Journal, 579: 1-61. 
Capítulo II. Bibliografía

20. Elizaquível, P., Sánchez, G. and Aznar, R. 2011. Escherichia. In: Liu, D. (Ed.),

Molecular detection of human bacterial pathogens. CRC Press, Boca Raton, FL, USA, pp. 869-879.

21. EUCAST. 2012a. Método de difusión con discos para el estudio de la sensibilidad a los antimicrobianos. Disponible en: http://coesant-

seimc.org/documents/Método\%20de\%20difusión\%20con\%20discos.pdf. Última visita 24 de Marzo de 2014.

22. EUCAST. 2012b. Breakpoint tables for interpretation of MICs and zone diameters. Version 2.0. http://www.eucast.org. Última visita 24 de Marzo de 2014.

23. Farrokh, C., Jordan, K., Auvray, F., Glass, K., Oppegaard, H., Raynaud, S., Thevenot, D., Condron, R., De Reu, K. and Govaris, A. 2013. Review of Shiga-toxin-producing Escherichia coli (STEC) and their significance in dairy production. Int. J. Food Microbiol., 162 (2): 190-212.

24. Fratamico, P. M., Sackitey, S. K., Wiedmann, M. and Deng, M. Y. 1995. Detection of Escherichia coli 0157:H7 by multiplex PCR. J. Clin. Microbiol., 33: 2188-2191.

25. Gannon, V. P. I., Rashed, M., King, R. K. and Thomas, E. J. G. 1993. Detection and characterization of the eae gene of Shiga-like toxin-producing Escherichia coli using Polymerase Chain Reaction. J. Clin. Microbiol., 31: 1268-1274.

26. Gannon, V. P. I., D'Souza, S., Graham, T., King, R. K., Rahn, K. and Read, S. 1997. Use of the flagellar H7 Gene as a target in multiplex PCR assays and improved specificity in 
Capítulo II. Bibliografía

identification of Enterohemorrhagic Escherichia coli strains. J. Clin. Microbiol., 35: 656662.

27. González-Sanz, R., Herrera-León, S., De La Fuente, M., Arroyo, M. and Echeita, M.

A. 2009. Emergence of extended-spectrum $\beta$-lactamases and AmpC-type $\beta$-lactamases in human Salmonella isolated in Spain from 2001 to 2005. J. Antimicrob. Chemother., 64: 1181-1186.

28. Griggs, D. J., Gensberg, K. and Piddock, L. 1996. Mutations in gyrA gene of quinolone-resistant Salmonella serotypes isolated from humans and animals. Antimicrob. Agents Chemother., 40: 1009-1013.

29. Guerra, B., Soto, S. M., Argüelles, J. M. and Mendoza, M. C. 2001. Multidrug resistance is mediated by large plasmids carrying a class 1 integron in the emergent Salmonella enterica serotype [4, 5, 12: i:-]. Antimicrob. Agents Chemother., 45: 13051308.

30. Guerra, B., Junker, E., Miko, A., Helmuth, R. and Mendoza, M. 2004.

Characterization and localization of drug resistance determinants in multidrugresistant, integron-carrying Salmonella enterica serotype Typhimurium strains. Microbial Drug Resistance, 10: 83-91.

31. Gyles, C. 2007. Shiga toxin-producing Escherichia coli: an overview. J. Anim. Sci., 85: E45-E62. 
32. Harder, K. J., Nikaido, H. and Matsuhashi, M. 1981. Mutants of Escherichia coli that are resistant to certain beta-lactam compounds lack the ompF porin. Antimicrob. Agents Chemother., 20: 549-552.

33. Heuvelink, A. E., Van Den Biggelaar, F. L. A. M., De Boer, E., Herbes, R. G., Melchers, W. J. G., Huis, J. H. J. and Monnens, L. A. H. 1998. Isolation and characterization of verocytotoxin-producing Escherichia coli 0157 strains from Dutch cattle and sheep. J. Clin. Microbiol., 36: 878-882.

34. Karczmarczyk, M., Abbott, Y., Walsh, C., Leonard, N. and Fanning, S. 2011. Characterization of multidrug-resistant Escherichia coli isolates from animals presenting at a university veterinary hospital. Appl. Environ. Microbiol., 77: 7104-7112.

35. Khakhria, R., Duck, D. and Lior, H. 1990. Extended phage-typing scheme for Escherichia coli 0157:H7. Epidemiol. Infect., 105: 511-520.

36. Khan, A., Das, S. C., Ramamurthy, T., Sikdar, A., Khanam, J., Yamasaki, S., Takeda, Y. and Nair, G. B. 2002. Antibiotic resistance, virulence gene, and molecular profiles of Shiga toxin-producing Escherichia coli isolates from diverse sources in Calcutta, India. J. Clin. Microbiol., 40: 2009-2015.

37. LeJeune, J. T., Besser, T. E. and Hancock, D. D. 2001. Cattle water troughs as reservoirs of Escherichia coli 0157. Appl. Environ. Microbiol., 67: 3053-3057.

38. Levesque, C., Piche, L., Larose, C. and Roy, P. H. 1995. PCR mapping of integrons reveals several novel combinations of resistance genes. Antimicrob. Agents Chemother., 39: 185-191. 
39. Lin, A., Sultan, O., Lau, H. K., Wong, E., Hartman, G. and Lauzon, C. R. 2011. O serogroup specific real time PCR assays for the detection and identification of nine clinically relevant non-0157 STECs. Food Microbiol., 28: 478-483.

40. Liu, Y., DebRoy, C. and Fratamico, P. 2007. Sequencing and analysis of the Escherichia coli serogroup 0117, 0126, and 0146 O-antigen gene clusters and development of PCR assays targeting serogroup 0117-, O126-, and 0146-specific DNA sequences. Mol. Cell. Probes, 21: 295-302.

41. Lou, H., Chen, M., Black, S. S., Bushell, S. R., Ceccarelli, M., Mach, T., Beis, K., Low, A. S., Bamford, V. A. and Booth, I. R. 2011. Altered antibiotic transport in OmpC mutants isolated from a series of clinical strains of multi-drug resistant $E$. coli. PloS one, 6: e25825.

42. Machado, J., Grimont, F. and Grimont, P. A. D. 2000. Identification of Escherichia coli flagellar types by restrictionof the amplified flic gene. Res. Microbiol., 151: 535546.

43. Madsen, L., Aarestrup, F. M. and Olsen, J. E. 2000. Characterisation of streptomycin resistance determinants in Danish isolates of Salmonella Typhimurium. Vet. Microbiol., 75: 73-82.

44. Martin, A. \& Beutin, L. 2011. Characteristics of Shiga toxin-producing Escherichia coli from meat and milk products of different origins and association with food producing animals as main contamination sources. Int. J. Food Microbiol., 146: 99-104. 
Capítulo II. Bibliografía

45. Meng, J., Jeffrey, T. L., Zhao, T. and Doyle, M. P. 2013. Enterohemorrhagic

Eshcerichia coli. In: Doyle, M. P. and Buchanan, R. L. (Eds.), Food Microbiology:

Fundamentals and Frontiers. American Society for Microbiology Press, Washington DC, USA, pp. 287-309.

46. Michelacci, V., Tozzoli, R., Caprioli, A., Martínez, R., Scheutz, F., Grande, L., Sánchez, S. and Morabito, S. 2013. A new pathogenicity island carrying an allelic variant of the Subtilase cytotoxin is common among Shiga toxin producing Escherichia coli of human and ovine origin. Clin. Microbiol. and Infect., .

47. Monday, S., Beisaw, A. and Feng, P. 2007. Identification of Shiga toxigenic Escherichia coli seropathotypes A and B by multiplex PCR. Mol. Cell. Probes, 21: 308311.

48. Mora, A., Blanco, J. E., Blanco, M., Alonso, M. P., Dhabi, G., Echeita, A., González, E. A., Bernárdez, M. I. and Blanco, J. 2005. Antimicrobial resistance of Shiga toxin (verotoxin)-producing Escherichia coli 0157: H7 and non-0157 strains isolated from humans, cattle, sheep and food in Spain. Res. Microbiol., 156: 793-806.

49. Mora, A., Blanco, M., Blanco, J. E., Alonso, M. P., Dhabi, G., Thomson-Carter, F., Usera, M. A., Bartolomé, R., Prats, G. and Blanco, J. 2004. Phage types and genotypes of Shiga toxin-producing Escherichia coli O157: $\mathrm{H} 7$ isolates from humans and animals in Spain: identification and characterization of two predominating phage types (PT2 and PT8). J. Clin. Microbiol., 42: 4007-4015.

50. Ng, L. K., Martin, I., Alfa, M. and Mulvey, M. 2001. Multiplex PCR for the detection of tetracycline resistant genes. Mol. Cell. Probes, 15: 209-215. 
51. Ng, L. K., Mulvey, M. R., Martin, I., Peters, G. A. and Johnson, W. 1999. Genetic characterization of antimicrobial resistance in Canadian isolates of Salmonella serovar Typhimurium DT104. Antimicrob. Agents Chemother., 43: 3018-3021.

52. Nikaido, H. 2003. Molecular basis of bacterial outer membrane permeability revisited. Microbiol. Mol. Biol. Rev., 67: 593-656.

53. Olsen, J. E., Aabo, S., Hill, W., Notermans, S., Wernars, K., Granum, P. E., Popovic, T., Rasmussen, H. N. and Olsvik, O. 1995. Proves and polymerase chain reaction for detection of food-borne bacterial pathogens. Int. J. Food Microbiol., 28: 1-78.

54. Oporto, B., Esteban, J. I., Aduriz, G., Juste, R. A. and Hurtado, A. 2008. Escherichia coli 0157: $\mathrm{H} 7$ and non-O157 Shiga toxin-producing $E$. coli in healthy cattle, sheep and swine herds in northern Spain. Zoonoses and public health, 55: 73-81.

55. Orden, J. A., Horcajo, P., de la Fuente, R., Ruiz-Santa-Quiteria, J. A., DomínguezBernal, G. and Carrión, J. 2011. Subtilase cytotoxin-coding genes in verotoxinproducing Escherichia coli strains from sheep and goats differ from those from cattle. Appl. Environ. Microbiol., 77: 8259-8264.

56. Oswald, E., Schmidt, H., Morabito, S., Karch, H., Marchès, O. and Caprioli, A. 2000. Typing of intimin genes in human and animal Enterohemorrhagic and Enteropathogenic Escherichia coli: caracterization of a new intimin variant. Infection and Immunity, 68: 64-71.

57. Pagani, L., Dell'Amico, E., Migliavacca, R., D'Andrea, M. M., Giacobone, E., Amicosante, G., Romero, E. and Rossolini, G. M. 2003. Multiple CTX-M-type extended- 
Capítulo II. Bibliografía

spectrum $\beta$-lactamases in nosocomial isolates of Enterobacteriaceae from a hospital in northern Italy. J. Clin. Microbiol., 41: 4264-4269.

58. Pagès, J., James, C. E. and Winterhalter, M. 2008. The porin and the permeating antibiotic: a selective diffusion barrier in Gram-negative bacteria. Nat. Rev. Microbiol., 6: 893-903.

59. Paton, A. W., Srimanote, P., Talbot, U. M., Wang, H. and Paton, J. C. 2004. A new family of potent AB5 cytotoxins produced by Shiga toxigenic Escherichia coli. J. Exp. Med., 200: 35-46.

60. Paton, A. W. \& Paton, J. C. 2002. Direct detection and characterization of Shiga toxigenic Escherichia coli by multiplex PCR for stx1, stx2, eae, ehxA, and saa. J. Clin. Microbiol., 40: 271-274.

61. Paton, J. C. \& Paton, A. W. 1998. Pathogenesis and diagnosis of Shiga toxinproducing Escherichia coli infections. Clin. Microbiol. Rev., 11: 450-479.

62. Perelle, S., Dilasser, F., Grout, J. and Fach, P. 2004. Detection by $5{ }^{`}$-nuclease PCR of Shiga-toxin producing Escherichia coli 026, 055, 091, 0103, 0111, 0113, 0145 and 0157: H7, associated with the world's most frequent clinical cases. Mol. Cell. Probes, 18: $185-192$.

63. Pollard, D. R., Johnson, W. M., Lior, H., Tyler, S. D. and Rozee, K. R. 1990. Rapid and specific detection of Verotoxin genes in Escherichia coli by the Polymerase Chain Reaction. J. Clin. Microbiol., 28: 540-545. 
Capítulo II. Bibliografía

64. Randall, L., Cooles, S., Osborn, M., Piddock, L. and Woodward, M. 2004. Antibiotic resistance genes, integrons and multiple antibiotic resistance in thirty-five serotypes of Salmonella enterica isolated from humans and animals in the UK. J. Antimicrob. Chemother., 53: 208-216.

65. Rey, J., Blanco, J. E., Blanco, M., Mora, A., Dahbi, G., Alonso, J. M., Hermoso, M., Hermoso, J., Alonso, M. P., Usera, M. A., Gonzalez, E. A., Bernardez, M. I. and Blanco, J. 2003. Serotypes, phage types and virulence genes of shiga-producing Escherichia coli isolated from sheep in Spain. Vet. Microbiol., 94: 47-56.

66. Sánchez, S., Martinez, R., Garcia, A., Blanco, J., Blanco, J. E., Blanco, M., Dahbi, G., Lopez, C., Mora, A., Rey, J. and Alonso, J. M. 2009. Longitudinal study of Shiga toxinproducing Escherichia coli shedding in sheep feces: persistence of specific clones in sheep flocks. Appl. Environ. Microbiol., 75: 1769-1773.

67. Sandvang, D., Aarestrup, F. M. and Jensen, L. B. 1998. Characterisation of integrons and antibiotic resistance genes in Danish multiresistant Salmonella enterica Typhimurium DT104. FEMS Microbiol. Lett., 160: 37-41.

68. Scheutz, F., Teel, L. D., Beutin, L., Pierard, D., Buvens, G., Karch, H., Mellmann, A., Caprioli, A., Tozzoli, R., Morabito, S., Strockbine, N. A., Melton-Celsa, A. R., Sanchez, M., Persson, S. and O'Brien, A. D. 2012. Multicenter evaluation of a sequence-based protocol for subtyping Shiga toxins and standardizing Stx nomenclature. J. Clin. Microbiol., 50: 2951-2963.

69. Tenover, F. C. 2006. Mechanisms of antimicrobial resistance in bacteria. Am. J. Med., 119: S3-S10. 
Capítulo II. Bibliografía

70. Tozzoli, R., Caprioli, A., Cappannella, S., Michelacci, V., Marziano, M. L. and Morabito, S. 2010. Production of the subtilase AB5 cytotoxin by Shiga toxin-negative Escherichia coli. J. Clin. Microbiol., 48: 178-183.

71. Vettorato, M. P., Leomil, L., Guth, B. E. C., Irino, K. and Pestana de Castro, A. F. 2003. Properties of Shiga toxin-producing Escherichia coli (STEC) isolates from sheep in the State of São Paulo, Brazil. Vet. Microbiol., 95: 103-109.

72. Vettorato, M., De Castro, A., Cergole-Novella, M., Camargo, F., Irino, K. and Guth, B. 2009. Shiga toxin-producing Escherichia coli and atypical enteropathogenic Escherichia coli strains isolated from healthy sheep of different populations in São Paulo, Brazil. Lett. Appl. Microbiol., 49: 53-59.

73. Wang, G., Clark, C. G. and Rodgers, F. G. 2002. Detection in Escherichia coli of the genes encoding the major virulence factors, the genes defining the 0157:H7 serotype, and components of the type 2 Shiga toxin family by multiplex PCR. J. Clin. Microbiol., 40: 3613-3619.

74. Yan, J. J., Ko, W. C., Jung, Y. C., Chuang, C. L. and Wu, J. J. 2002. Emergence of Klebsiella pneumoniae isolates producing inducible DHA-1 $\beta$-lactamase in a university hospital in Taiwan. J. Clin. Microbiol., 40: 3121-3126.

75. Yoo, M. H., Huh, M., Kim, E., Lee, H. and Jeong, H. D. 2003. Characterization of chloramphenicol acetyltransferase gene by multiplex polymerase chain reaction in multidrug-resistant strains isolated from aquatic environments. Aquaculture, 217: 1121. 
Capítulo II. Bibliografía

76. Zschöck, M., Hamann, H. P. and Wolter, W. 2000. Shiga-toxin-producing Escherichia coli in faeces of healthy dairy cows, sheep and goats: prevalence and virulence properties. Lett. Appl. Microbiol., 31: 203-208.

77. Zweifel, C., Zychowska, M. A. and Stephan, R. 2004. Prevalence and characteristics of Shiga toxin-producing Escherichia coli, Salmonella spp. and Campylobacter spp. isolated from slaughtered sheep in Switzerland. Int. J. Food Microbiol., 92: 45-53. 
Capítulo II. Bibliografía 


\section{CAPÍTULO III: Caracterización y}

estudio comparativo de cepas de Escherichia coli enteropatogénico (EPEC) procedentes de leche de oveja, muestras ambientales y de pacientes 



\section{INTRODUCCIÓN}

Escherichia coli enteropatogénico (EPEC) es un importante agente de diarrea infantil en países en vías de desarrollo, siendo responsable de índices de mortalidad elevados (30\%) (Chen \& Frankel, 2005). Algunos serotipos pertenecientes a cepas de EPEC típicas (tEPEC) se encuentran asociados principalmente a diarreas en niños menores de un año, mientras que en niños mayores de un año la frecuencia es mucho menor. En personas adultas, las infecciones por estos serotipos son muy raras. El aumento de la resistencia en niños mayores y en adultos puede estar asociado al desarrollo de inmunidad o a la pérdida de receptores para determinadas adhesinas. En el caso de cepas de EPEC atípicas (aEPEC), algunos trabajos publicados demuestran tanto su implicación como agentes productores de diarreas en todos los grupos de edad como su carácter emergente en países desarrollados (Trabulsi et al., 2002; Hernandes et al., 2009).

En animales no se suelen aislar cepas de tEPEC, lo que sugiere que el hombre es el único reservorio de estos microorganismos. Por otro lado, se han publicado estudios en los que se han aislado cepas de aEPEC procedentes de muestras humanas y de animales sanos y enfermos de diferentes especies. Entre éstos, muchos pertenecían a especies destinadas a la producción de alimentos como ungulados domésticos y aves de corral, aunque también se han detectado cepas de aEPEC en animales de compañía (perros y gatos), venados y simios (Trabulsi et al., 2002; Hernandes et al., 2009). Aunque no existe evidencia de la transmisión directa animal-hombre, algunas cepas de aEPEC aisladas de animales pertenecen a serogrupos asociados a enfermedad en humanos como son: $\mathrm{O} 26, \mathrm{O} 103, \mathrm{0119}, 0128$ y 0142 , lo que sugiere que los animales pueden ser un importante reservorio de aEPEC, pudiendo, por tanto, constituir, los animales de abasto y los alimentos derivados de ellos, una fuente de transmisión para el hombre (Hernandes et al., 2009). Asimismo, la leche y los productos lácteos aparecen frecuentemente contaminados con cepas de aEPEC (Silva et al., 2001; Holko et al., 2006; García Díez et al., 2009). Por tanto, teniendo en cuenta lo expuesto anteriormente, se podría asumir un posible acceso de estas cepas al hombre vía los alimentos de origen animal como puede ser la leche de oveja y el más importante de sus productos derivados en España; los quesos elaborado con leche cruda. 
Capítulo III. Introducción

\section{OBJETIVO}

El objetivo del trabajo presentado en este capítulo ha sido determinar la presencia de cepas de aEPEC en leche de oveja y en el ambiente de la explotación así como comparar filogenéticamente las cepas obtenidas de estos hábitats con otras aisladas de coprocultivos humanos, siendo el fin último intentar identificar posibles rutas de transmisión. 


\section{MATERIAL Y MÉTODOS}

\section{AISLAMIENTO DE CEPAS EPEC A PARTIR DE COPROCULTIVOS HUMANOS}

Durante los meses de Marzo a Mayo del año 2011 se recibieron muestras de coprocultivos procedentes de pacientes afectos de diarrea (Hospital de León). Estas muestras consistían en:

> Placas con colonias obtenidas por siembra directa de heces en Columbia Agar (Becton Dickinson, Sparks, MD, USA) con 5\% de sangre ovina.

Placas con colonias obtenidas por siembra directa de heces en CT-SMAC (BioMérieux, Marcy l'Etoile, Francia).

En nuestro laboratorio, se tomó un número representativo de colonias de cada una de las placas que se sometieron a un enriquecimiento no selectivo en Nutrient Broth (NB, Oxoid) con extracto de levadura (YE) (Oxoid, Basingstoke, UK) al 0,6\% durante 24 horas a $37 \circ$ C. Posteriormente, se procedió a sembrar los enriquecimientos en el medio selectivo y diferencial CT-SMAC (Oxoid) y, mediante PCR, se investigó en los caldos, la presencia de los genes que codifican para las toxinas Shiga (stxs) y la intimina (eae), utilizando las condiciones descritas anteriormente (apartado 5 del Material y Métodos del capítulo I). Finalmente se analizaron mediante PCR las colonias obtenidas de los enriquecimientos positivos. Las cepas stx- y eae+ se guardaron a -40 으 en NB (Oxoid) con glicerol (40\%) (Acofarma, Barcelona, España) para caracterizarlas posteriormente.

\section{CEPAS OBJETO DEL ESTUDIO}

Se caracterizaron cepas sospechosas procedentes de muestras de leche de tanque, muestreos de explotaciones (véase Capítulo I) y las obtenidas de muestras clínicas. 


\section{CARACTERIZACIÓN DE LAS CEPAS EPEC}

\subsection{Caracterización fenotípica de las cepas aisladas de leche de tanque}

Los aislados obtenidos de la leche de ovino se caracterizaron fenotípicamente utilizando el sistema miniaturizado $\mathrm{Api}^{\circledR}$ 20E (BioMérieux) diseñado para la identificación de especies pertenecientes a la familia Enterobacteriaceae y otros bacilos Gram negativos. Incluye 20 pruebas bioquímicas que se analizan mediante una base de datos (http://apiweb.biomerieux.com).

\subsection{Detección de genes mediante PCR}

En las presuntas cepas de EPEC se investigó, mediante PCR, la presencia de los genes que se citan a continuación:

Genes que codifican para las toxinas Shiga stx1 (Pollard et al., 1990) y stx2 (Olsen et al., 1995).

$>$ El gen que codifica para la intimina (eae) (Oswald et al., 2000).

$>$ El plásmido de adherencia EPEC (pEAF) (Franke et al., 1994).

$>$ El gen que codifica para la adhesina BFP (bfpA) (Gunzburg et al., 1995).

En la Tabla III.1 se presentan los genes y las secuencias de los cebadores utilizados para la detección de cepas EPEC. 
Tabla III.1. Genes objeto del estudio, secuencias de los cebadores utilizados e información relativa a la técnica de PCR empleada para la detección de cepas EPEC.

\begin{tabular}{|c|c|c|c|c|c|}
\hline Diana & Cebador & Secuencia $\left(5^{\prime} \rightarrow 3^{\prime}\right)$ & $\begin{array}{c}\text { Tamaño } \\
\left(\mathrm{pb}^{\mathrm{a}}\right)\end{array}$ & Referencia & $\begin{array}{c}\text { Condiciones } \\
\text { PCR }^{\mathrm{b}}\end{array}$ \\
\hline \multirow{2}{*}{ stx1 } & VT1a & GAAGAGTCCGTGGGATTACG & \multirow{2}{*}{130} & (Pollard et al., & \multirow{2}{*}{$A$} \\
\hline & VT1b & AGCGATGCAGCTATTAATAA & & 1990) & \\
\hline \multirow{2}{*}{ stx2 } & SLTII1 & CTTCGGTATCCTATTCCCGG & \multirow{2}{*}{448} & (Olsen et al., & \multirow{2}{*}{$A$} \\
\hline & SLTII2 & GGATGCATCTCTGGTCATTG & & 1995) & \\
\hline \multirow{2}{*}{ eae } & SK1 & CCCGAATTCGGCACAAGCATAAGC & \multirow{2}{*}{881} & (Oswald et al., & \multirow{2}{*}{$A$} \\
\hline & SK2 & CCCGGATCCGTCTCGCCAGTATTCG & & 2000) & \\
\hline \multirow{2}{*}{$\mathrm{pEAF}$} & EAF1 & CAGGGTAAAAGAAAGATGATAA & \multirow{2}{*}{397} & (Franke et al., & \multirow{2}{*}{ B } \\
\hline & EAF25 & TATGGGGACCATGTATTATCA & & 1994) & \\
\hline \multirow{2}{*}{$b f p A$} & EP1 & AATGGTGCTTGCGCTTGCTGC & \multirow{2}{*}{326} & (Gunzburg et al., & \multirow{2}{*}{ A } \\
\hline & EP2 & GCCGCTTTATCCAACCTGGTA & & 1995) & \\
\hline
\end{tabular}

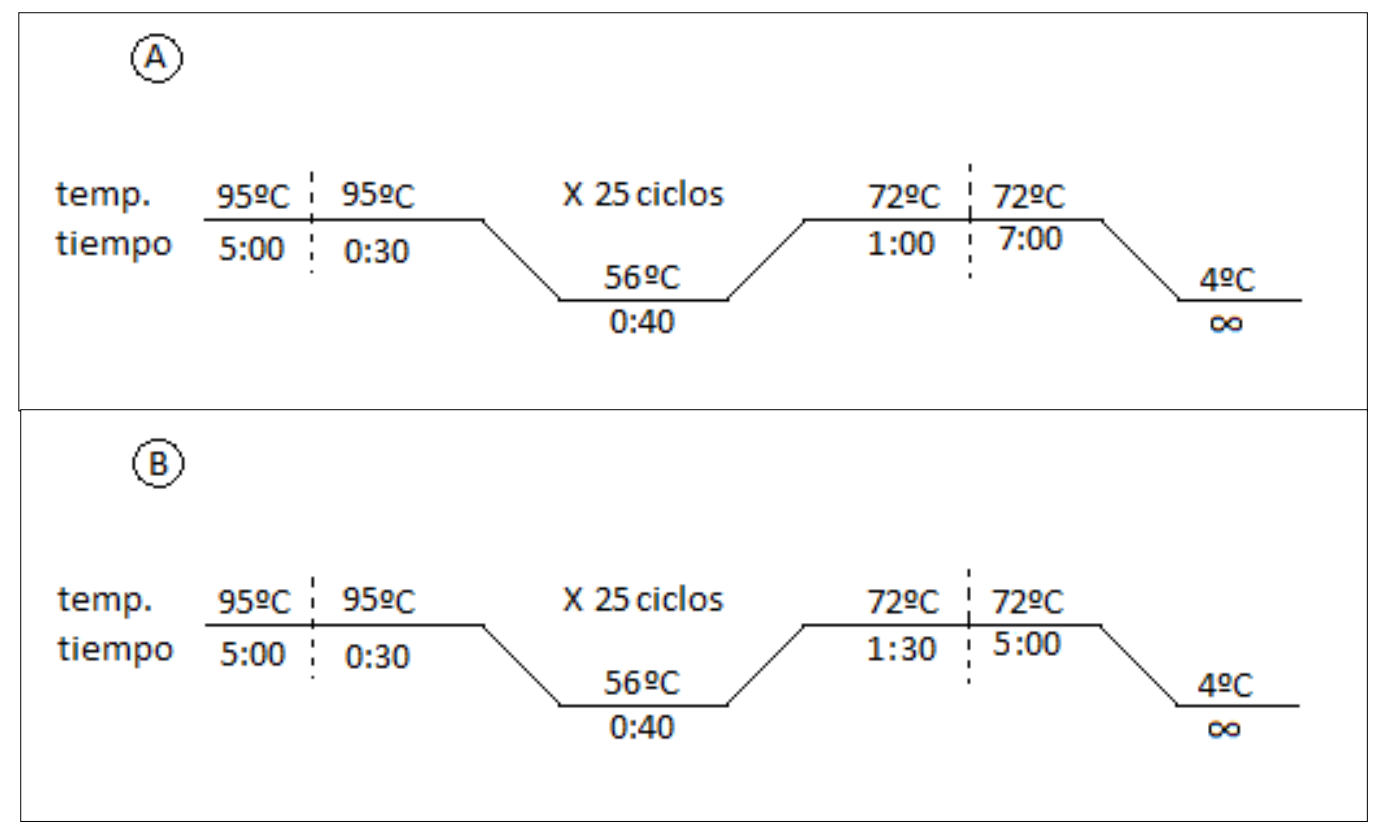

Figura III.1. Condiciones de las técnicas PCR utilizadas en la detección de cepas EPEC.

Las reacciones de amplificación se llevaron a cabo en un termociclador Applied Biosystems 2720 (Life Technologies S.A., Applied Biosystems división, Madrid, España). Finalmente el producto de PCR fue resuelto mediante electroforesis en un gel de agarosa (Pronadisa, Chemie Brunschwig, Basel, Suiza) al 1,5\% en Tris-Acetic Acid-EDTA (TAE, Laboratorios Conda) y posteriormente para su revelado se sumergió en una 
solución con $10 \mathrm{mg} / \mathrm{ml}$ de Bromuro de etidio (AppliChem, Darmstadt, Alemania). Se observaron los resultados exponiendo el gel a la luz ultravioleta en un transiluminador (Bio-Rad Laboratories, Hercules, CA, USA) y se realizó la captura de la imagen mediante el equipo Molecular Imager GelDoc XR System (Bio-Rad Laboratories).

\subsection{Multilocus Sequence Typing (MLST)}

Se llevó a cabo la amplificación, purificación y secuenciación de siete genes "housekeeping" ( $\operatorname{arcA}, c y a A, f a d D$, icdA, Iys $P, m t / D, r p o S)$. Se seleccionaron estos genes (Tabla III.2) debido a que en estudios anteriores se vio que eran los que presentaban una mayor variabilidad (Moura et al., 2009). El protocolo seguido, junto con los cebadores utilizados fue el propuesto en la web EcMLST (http://www.shigatox.net/new/tools/ecmlst.html). La Figura III.2 informa de las condiciones de la técnica de PCR utilizada para la amplificación de los genes "housekeeping" del MLST.

Tabla III.2. Cebadores utilizados para la amplificación de los genes "housekeeping" del MLST.

\begin{tabular}{|c|c|c|c|c|}
\hline Diana & Cebador & Secuencia $\left(5^{\prime} \rightarrow 3^{\prime}\right)$ & $\begin{array}{c}\text { Tamaño } \\
(\mathrm{pb})^{\mathrm{a}}\end{array}$ & Referencia \\
\hline \multirow{2}{*}{$\operatorname{arcA}$} & $\operatorname{arcA-F1}$ & GACAGATGGCGCGGAAATGC & \multirow{2}{*}{552} & \\
\hline & $\operatorname{arcA-R2}$ & TCCGGCGTAGATTCGAAATG & & \\
\hline \multirow{2}{*}{ суаA } & cyaA-F3 & CTCGTCCGTAGGGCAAAGTT & \multirow{2}{*}{571} & \\
\hline & cyaA-R3 & AATCTCGCCGTCGTGCAAAC & & \\
\hline \multirow{2}{*}{$f a d D$} & fadD-F6 & GCTGCCGCTGTATCACATTT & \multirow{2}{*}{580} & \\
\hline & fadD-R3 & GCGCAGGAATCCTTCTTCAT & & http://www.shig \\
\hline \multirow{2}{*}{$i c d A$} & icd-F2 & CTGCGCCAGGAACTGGATCT & \multirow{2}{*}{669} & atox.net/new/to \\
\hline & icd-R2 & ACCGTGGGTGGCTTCAAACA & & ols/ecmlst.html \\
\hline \multirow{2}{*}{ lysP } & lysP-F1 & CTTACGCCGTGAATTAAAGG & \multirow{2}{*}{628} & \\
\hline & lysP-R8 & GGTTCCCTGGAAAGAGAAGC & & \\
\hline \multirow{2}{*}{$m t / D$} & mtID-F2 & GCAGGTAATATCGGTCGTGG & \multirow{2}{*}{658} & \\
\hline & mtID-R3 & CGAGGTACGCGGTTATAGCAT & & \\
\hline \multirow{2}{*}{ rpos } & rpoS-F3 & CGCCGGATGATCGAGAGTAA & \multirow{2}{*}{618} & \\
\hline & rpos-R1 & GAGGCCAATTTCACGACCTA & & \\
\hline
\end{tabular}

apb: Pares de bases 


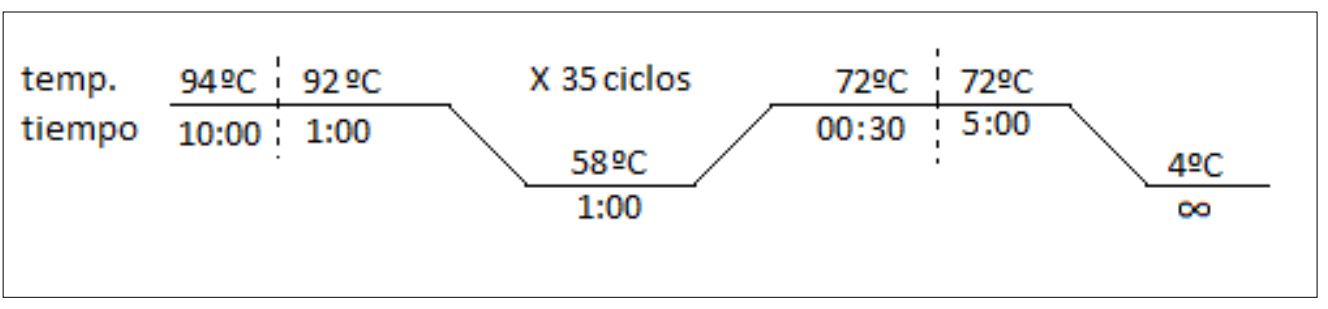

Figura III.2. Condiciones de PCR para la amplificación de los genes "housekeeping" del MLST.

Una vez realizada la PCR, los productos obtenidos fueron purificados con el kit NucleoSpin ${ }^{\circledR}$ Gel and PCR Clean-up (Macherey-Nagel, Düren, Alemania) siguiendo las indicaciones del fabricante.

Las reacciones de secuenciación fueron realizadas en el Laboratorio de Técnicas Instrumentales (LTI) de la Universidad de León. Se utilizó el secuenciador Megabace 500 (Amersham Biosciences, Piscataway, NJ, USA).

Las secuencias obtenidas fueron revisadas y editadas mediante el uso del software Chromas Lite 2.1 (http://technelysium.com.au/). A cada uno de los loci de los diferentes genes se le asignó un número de alelo comparando estas secuencias con las correspondientes a los loci de los genes que aparecen en la base de datos de la web ECMLST (http://www.shigatox.net/new/tools/ecmlst.html) empleando la utilidad MegAling (algoritmo ClustalW) del software Lasergene Core Suite versión 7.0.0 (DNASTAR) para la comparación. A cada cepa se le asignó un número arbitrario de "sequence type" (ST) en función del perfil de alelos que presentaba. Se formaron grupos clonales en función de la presencia de variantes sencillas en uno o dos loci utilizando el algoritmo eBursts del programa START2 (Jolley et al., 2001) versión 0.9.0 beta. Finalmente se construyeron secuencias concatenadas a partir de las secuencias individuales de los diferentes genes de una cepa representativa de cada uno de los ST. Se alinearon estas secuencias y se construyó el árbol filogénetico correspondiente utilizando el método Neighbor-Joining (NJ) estimando las distancias con el modelo de parámetro-2 de Kimura y un "bootstrap" de 1000 repeticiones utilizando el software MEGA5 (Tamura et al., 2011). 
Capítulo III. Material y métodos

\subsection{Electroforesis en campo pulsado (PFGE)}

El protocolo utilizado se corresponde con el descrito en el punto 2.2.4 del Material y métodos del Capítulo II. 
Capítulo III. Resultados

\section{RESULTADOS}

\section{AISLAMIENTO Y CARACTERIZACIÓN DE CEPAS EPEC}

Se obtuvieron un total de 81 presuntas cepas de EPEC: 62 (76,5\%) de leche de tanque, $10(12,4 \%)$ de explotaciones y $9(11,1 \%)$ de pacientes. Todas ellas presentaban el gen que codifica para la intimina (eae) y carecían de los genes que codifican para las toxinas Stxs (stx1 y stx2). Tampoco se detectó el plásmido de adherencia EPEC (pEAF) ni la adhesina BFP (bfpA). Por tanto, se consideraron aEPEC.

Para las 62 cepas aisladas de leche de tanque, la caracterización fenotípica con el sistema miniaturizado $\mathrm{Api}^{\circledR}$ 20E dio los siguientes resultados: $43(69,4 \%)$ fueron identificadas como Escherichia coli, 5 (8,1\%) como Hafnia alvei, 4 (6,5\%) como Enterobacteo cloaceae, 3 (4,8\%) como Raoultella ornithinolytica, 2 (3,2\%) como Chronobacterium violaceum, 1 (1,6\%) como Salmonella spp., 1 (1,6\%) como Enterobacter (Cronobacter) sakazakii, 1 (1,6\%) como Serratia odorífera, 1 (1,6\%) como Acinetobacterium baumanni y $1(1,6 \%)$ como Providencia rettgeri.

\section{TIPIFICACIÓN POR MLST}

Se secuenciaron siete genes "housekeeping" de las 81 cepas EPEC obteniendo 19 perfiles de alelos o sequence types (STs) diferentes (Tabla III.3). Diez de las secuencias obtenidas en cinco de estos genes no se correspondían con ninguno de los alelos descritos hasta el momento, y fueron registradas como nuevos alelos en la base de datos de la web ECMLST (http://www.shigatox.net/new/tools/ecmlst.html). Los dos genes que presentaron una mayor variabilidad fueron el icdA y el $m t / D$ con 12 alelos diferentes cada uno de ellos. El ST más frecuente fue el ST 14 con 41 aislados en total.

En un mismo ST se incluían cepas del mismo origen (ovino o humano), aunque en tres de los STs aparecen cepas de origen ovino y cepas aisladas de pacientes del Hospital de León. Estos tres perfiles alélicos son: el ST 14, con 37 de las cepas aisladas de leche de tanque y 4 cepas procedentes de pacientes; el ST 16 que incluía 1 cepa aislada de leche de tanque y 2 cepas procedentes de pacientes; y el ST 17 que incluía 2 cepas aisladas a partir de heces de ovino y 1 procedente de un paciente. 
Tabla III.3. Perfil de alelos, frecuencia y origen de los STs obtenidos en la tipificación por MLST de 87 cepas de EPEC.

\begin{tabular}{|c|c|c|c|c|c|c|c|c|c|}
\hline \multirow[b]{2}{*}{ ST } & \multicolumn{7}{|c|}{ Alelos de los genes "housekeeping" } & \multirow{2}{*}{$\begin{array}{c}\text { Frecuencia } \\
\text { (no de cepas) }\end{array}$} & \multirow{2}{*}{$\begin{array}{l}\text { Origen de los } \\
\text { aislados }\end{array}$} \\
\hline & $\operatorname{arcA}$ & cyaA & fadD & $i c d A$ & IysP & $m t / D$ & rpos & & \\
\hline 1 & 2 & $36^{a}$ & 115 & 8 & 17 & $45^{a}$ & $71^{a}$ & 1 & Clínica \\
\hline 2 & 3 & 2 & 13 & 4 & 1 & 13 & 1 & 1 & Leche \\
\hline 3 & 3 & 3 & 2 & 2 & 1 & 3 & 1 & 1 & Clínica \\
\hline 4 & 3 & 3 & 2 & 2 & 1 & 4 & 1 & 6 & Leche y agua \\
\hline 5 & 3 & 3 & 13 & 4 & 1 & 13 & 1 & 1 & Leche \\
\hline 6 & 3 & 3 & 13 & 39 & 1 & 13 & 17 & 1 & Heces \\
\hline 7 & 3 & 3 & 13 & $203^{a}$ & 1 & 13 & $69^{a}$ & 2 & Leche y agua \\
\hline 8 & 3 & 3 & 20 & 23 & 1 & 31 & 1 & 8 & Leche \\
\hline 9 & 3 & 3 & 20 & 23 & 1 & 31 & $70^{a}$ & 1 & Agua \\
\hline 10 & 3 & 3 & 49 & 4 & 1 & 13 & 1 & 1 & Leche \\
\hline 11 & 3 & 11 & 13 & 39 & 1 & $43^{a}$ & 1 & 3 & Leche y agua \\
\hline 12 & 6 & 1 & 4 & 3 & 2 & 11 & 8 & 1 & Leche \\
\hline 13 & 7 & 26 & 13 & 54 & 35 & 34 & 46 & 1 & Leche \\
\hline 14 & 8 & 2 & 1 & 15 & 1 & 2 & 1 & 41 & Leche y clínica \\
\hline 15 & 8 & 3 & 2 & 4 & 1 & 13 & 1 & 4 & Leche, heces y aire \\
\hline 16 & 9 & 2 & 1 & 1 & 1 & 41 & 1 & 3 & Leche y clínica \\
\hline 17 & 9 & 3 & 2 & 4 & 1 & 13 & 1 & 3 & Heces y clínica \\
\hline 18 & 24 & 32 & 6 & 75 & 4 & 42 & 26 & 1 & Leche \\
\hline 19 & $27^{a}$ & $35^{a}$ & 110 & 136 & 78 & $44^{a}$ & 17 & 1 & Agua \\
\hline
\end{tabular}

${ }^{a}$ Nuevos alelos registrados en la base de datos de la página web EcMLST

Del análisis mediante MLST se obtuvieron tres grupos clonales utilizando el algoritmo eBursts (Figura III.3). En uno de estos grupos clonales se incluían un total de siete STs $(2,5,6,7,10,15$ y 17), siendo identificado el ST 5 como el ST de origen. Como muestra la Figura III.3, el ST de origen aparece en el círculo central, en el siguiente círculo concéntrico se sitúan los STs con una variación en un locus ("single-locus variants" - SLVs) y, finalmente, en el círculo externo aparecen los STs que poseen variación en dos loci (“double-locus variants" - DLVs).

Además de este gran grupo clonal, se obtuvieron otros dos grupos clonales constituidos cada uno de ellos por dos STs diferenciados entre sí por una variación en un locus. En el primero de ellos se incluyen los STs 3 y 4 , mientras que en el segundo se incluyen los STs 8 y 9. Los ocho STs restantes $(1,11,12,13,14,16,18$ y 19) no fueron incluidos en ningún grupo clonal ("singletons"). 
Las distancias relativas entre los diferentes STs también fueron representadas en una red filogenética mediante el algoritmo eBursts (Figura III.4).

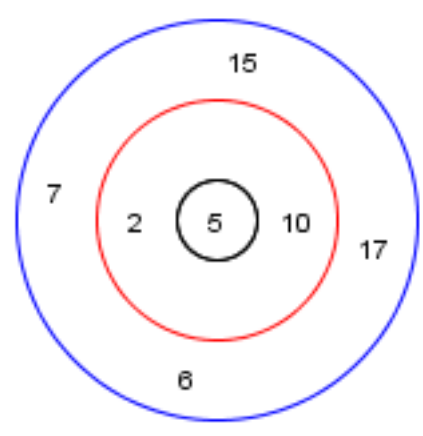

Figura III.3. Representación gráfica de las relaciones entre STs de uno de los grupos clonales obtenidos mediante el uso del algoritmo eBursts.

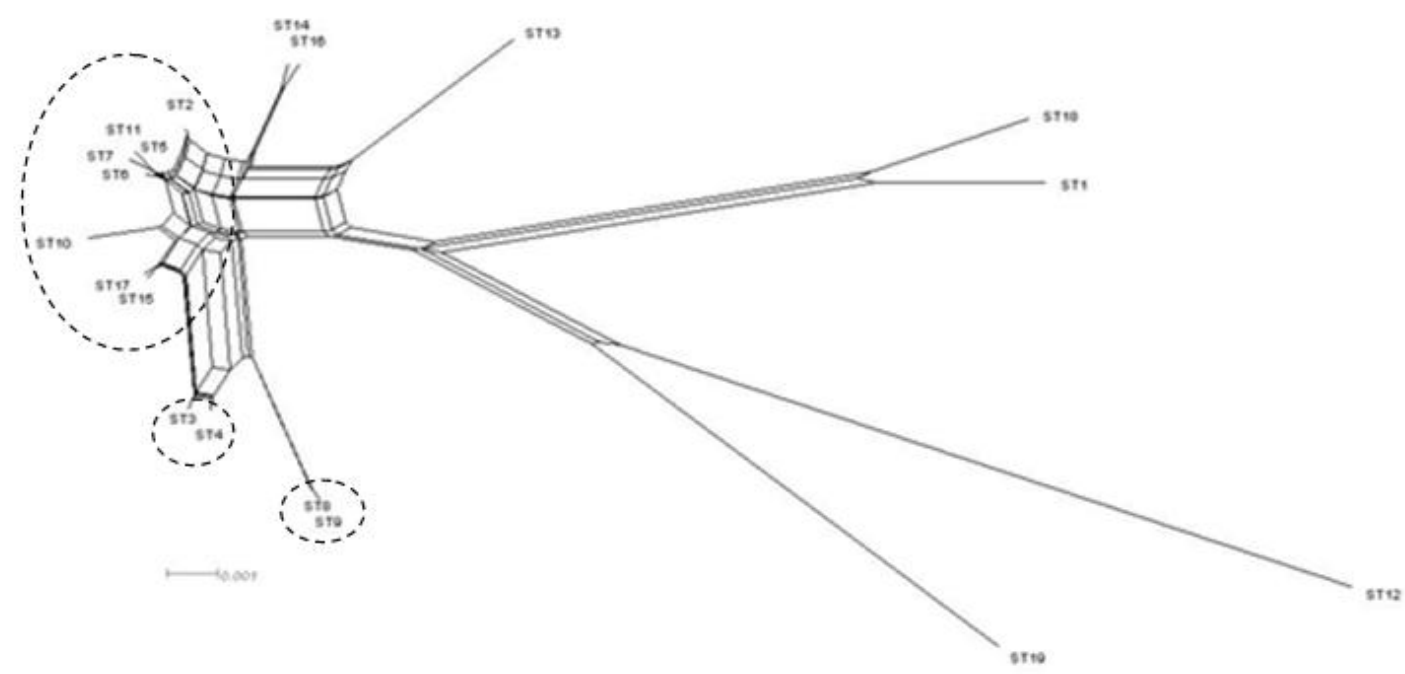

Figura III.4. Representación gráfica de la red filogenética obtenida mediante el método "split decomposition" (algoritmo eBursts). Se identifican los grupos clonales con un círculo.

Finalmente, con las secuencias concatenadas se construyó el árbol filogenético representado en la Figura III.5, que muestra una agrupación similar a la obtenida en la red filogenética con elevados valores bootstrapping. 


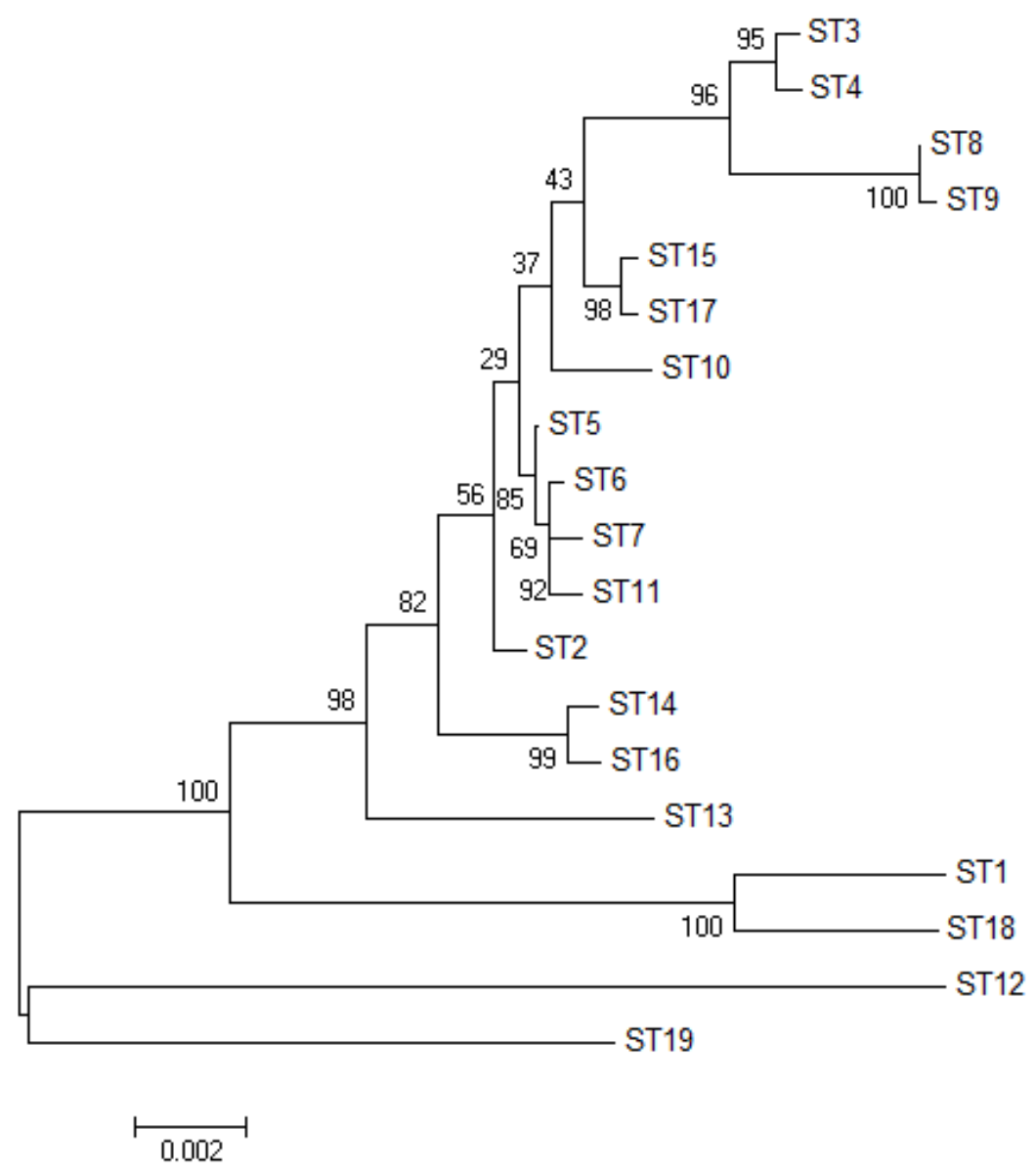

Figura III.5. Árbol filogenético de los perfiles de alelos (STs) de cepas aEPEC obtenidas mediante el método Neighbor-Joining. En los nodos de las ramas se presentan los valores bootstrapping.

\section{TIPIFICACIÓN POR PFGE}

El genotipado de las 81 cepas mediante PFGE dio lugar a 57 patrones de bandas diferentes divididos en 24 grupos (pulsotipos) con un valor de similitud de al menos el 74,5\% (Figura III. 6). Algunas cepas con un origen común presentaron un patrón de bandas idéntico, aunque se encontraron dos cepas con un mismo patrón de bandas procedentes de muestras de aire (F20VO) y de leche de tanque de otra explotación diferente (M313VO).

En 15 de los pulsotipos aparecen cepas de un mismo origen (leche de tanque, agua o muestras clínicas), mientras que los 9 restantes albergan cepas de diferentes orígenes: 
- Pulsotipo I: se agrupan cepas aisladas de muestras de leche de tanque que presentan un $81,5 \%$ de similitud con una cepa procedente de una muestra de agua de una explotación diferente.

- Pulsotipo IV: de forma similar a lo descrito para el pulsotipo I, este pulsotipo incluye una cepa aislada de una muestra de agua que presenta una similitud del $89,7 \%$ con una procedente de una muestra de leche de tanque de otra explotación diferente.

- Pulsotipo V: incluye dos cepas de origen ovino, una aislada de leche de tanque y otra de heces de diferentes explotaciones, con un nivel de similitud del $81,3 \%$.

- Pulsotipo VI: está formado por dos cepas, una aislada de leche de tanque y otra de origen humano, con una similitud del $87,5 \%$.

- Pulsotipo VII: formado por una cepa aislada de heces de ovino que se agrupa con un $88,6 \%$ de similitud con dos cepas procedentes de muestras de leche y aire que, a su vez, presentan un mismo patrón de bandas.

- Pulsotipo IX: una cepa aislada de heces ovinas forma un "cluster" (85,7\% de similitud) con una cepa de origen humano.

- Pulsotipo XV: comprende dos cepas, una aislada de leche de tanque y otra de origen humano, con un $79 \%$ de similitud.

- Pulsotipo XVII: "cluster" formado por dos cepas aisladas de leche de tanque y una cepa aislada de agua de otra explotación diferente (82,5\% de similitud).

- Pulsotipo XVIII: está formado por dos cepas procedentes de explotaciones diferentes, una aislada de leche de tanque y otra de agua, con un $83,9 \%$ de similitud. 


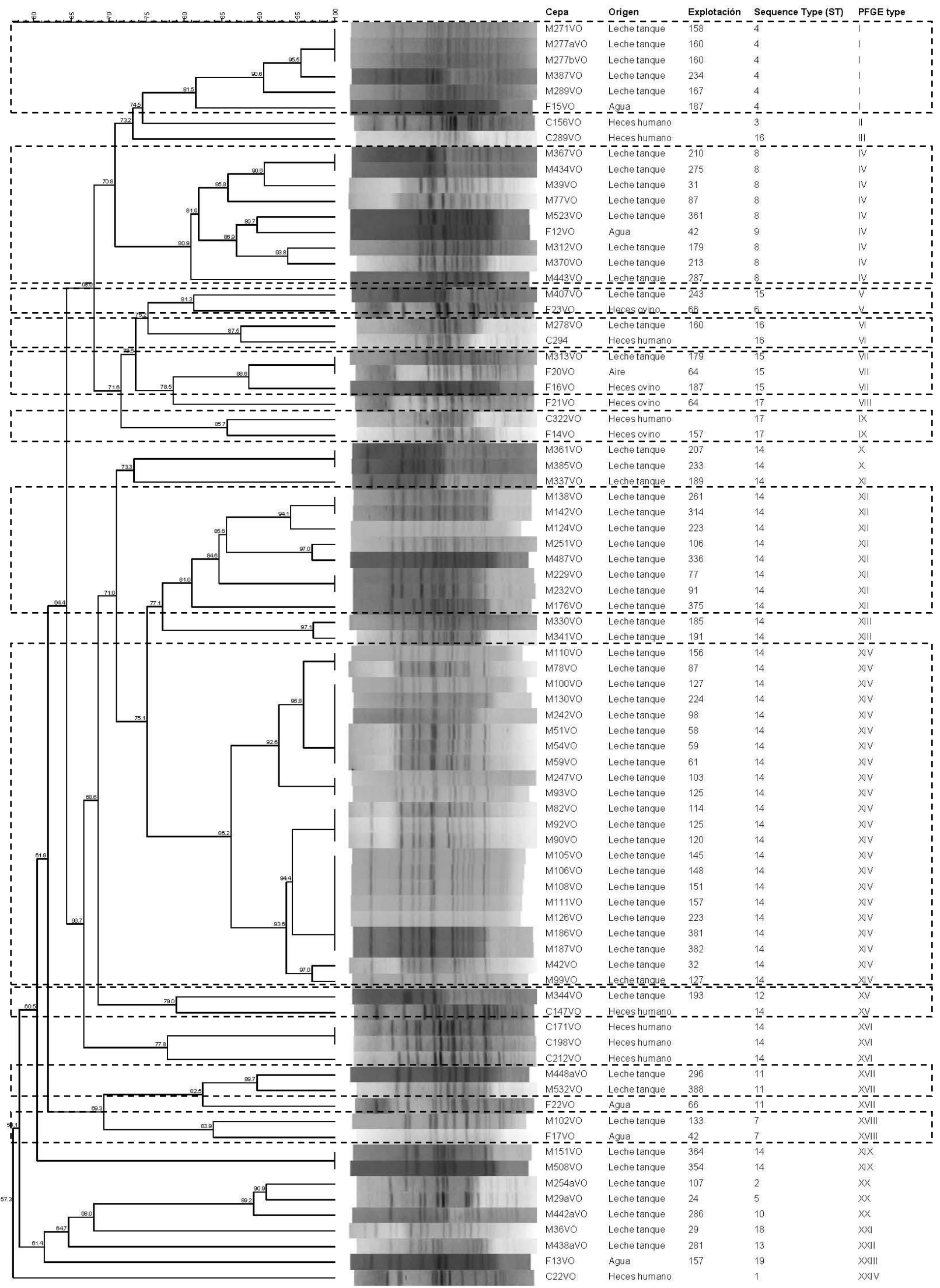

Figura III.6. Dendrograma Xbal-PFGE que muestra la relación genética entre las 81 cepas EPEC de origen ovino y humano. Además incluye los "Sequence Types" (STs) obtenidos mediante tipificación por MLST. 


\section{DISCUSIÓN}

De los 62 aislados procedentes de muestras de leche de ovino, solo el $69,4 \%$ fueron identificadas como E. coli por el sistema $A \mathrm{pi}^{\circledR}$ 20E. Por tanto, y como ya se observó en el estudio de las cepas de STEC (Capítulo II), este sistema miniaturizado no es útil para la identificación de cepas de ciertos grupos patógenos de la especie $E$. coli.

Ninguna de las 81 cepas aisladas (incluidas las nueve procedentes de pacientes con diarrea del Hospital de León) presentó el gen $b f p A$ ni el plásmido de adherencia pEAF, por lo que todas ellas se clasificaron como aEPEC. Esto confirma observaciones previas que indican que las cepas aEPEC son más frecuentes que las tEPEC en los países desarrollados y que se aíslan de diferentes especies de animales de abasto (Trabulsi et al., 2002; Hernandes et al., 2009).

Mediante el uso de la técnica MLST se obtuvieron 19 perfiles de alelos. Éstos STs pueden considerarse nuevos puesto que ninguno de ellos ha sido publicado en trabajos científicos anteriores cuando se han utilizando los genes "housekeeping" empleados por nosotros (Leomil et al., 2005; Moura et al., 2009). En nuestro estudio, el análisis por MLST permitió distinguir tres grupos clonales que incluían cepas de diferentes orígenes. El primer grupo clonal obtenido, constituido por siete STs, estaba formado por 13 cepas, que a su vez, estaban recogidas en 6 pulsotipos diferentes. En el ST de origen (ST 5; Figura III.3) se incluyó una única cepa procedente de leche; los STs 2 y 10 (con una sola variación en un locus) incluyeron, cada uno de ellos, una única cepa procedente de leche; los ST 6, ST 7, ST 15 y ST 17 (con variaciones en dos loci), incluían cepas procedentes de muestras de leche, heces, aire y agua. El segundo de los grupos clonales se formó con dos STs; el ST 3, que incluía una cepa de origen humano; y el ST 4, en el que se incluían cinco cepas procedentes de muestras de leche y otra procedente de agua. A su vez, estas siete cepas formaban parte de dos pulsotipos diferentes. El tercer grupo clonal estaba constituido por el ST 8, en el que se incluyeron ocho cepas procedentes de muestras de leche, y el ST 9 formado exclusivamente por una cepa procedente de agua. Estas nueve cepas se recogen en el pulsotipo I. Así pues, estos datos obtenidos del estudio por MLST de las cepas de EPEC indican una clara relación entre cepas procedentes de muestras de leche y agua. 
Los 19 perfiles alélicos (MLST), junto con los 24 pulsotipos obtenidos, muestran un elevado grado de heterogeneidad filogenética entre las cepas estudiadas. Esta diversidad genética parece ser un rasgo característico de las cepas aEPEC como recogen publicaciones previas (Afset et al., 2008). A pesar de esta heterogeneidad, la comparación de cepas ovinas (aisladas de muestras de leche y de diferentes orígenes en las explotaciones) con cepas de origen humano procedentes de pacientes con diarrea del Hospital de León muestra una clara relación epidemiológica; así, el ST mayoritario (ST 14) estaba compuesto por cepas de estos dos orígenes. Esta relación quedó demostrada también mediante el análisis PFGE (pulsotipos VI y XV). Otro hallazgo interesante en este estudio fue la relación encontrada entre cepas procedentes de muestras de leche y de agua. De hecho, cepas de ambos orígenes se agruparon en dos STs y cuatro pulsotipos.

El hombre es considerado el único reservorio de tEPEC. En la Introducción de este Capítulo se señaló que se han publicado estudios en los que se demuestra que se han aislado cepas de aEPEC tanto de animales sanos y enfermos de diferentes especies, en la mayoría destinadas a la producción de alimentos, aunque también de animales de compañía y animales salvajes (Silva et al., 2001; Holko et al., 2006; García Díez et al., 2009; Bandyopadhyay et al., 2012). Por tanto, diferentes especies animales pueden actuar como reservorio de estos microorganismos y representar una fuente de infección para humanos, tal y como otros autores han sugerido (Blanco et al., 2005; Moura et al., 2009). Los resultados obtenidos en este estudio no permiten determinar con exactitud las rutas de transmisión de aEPEC, pero indican que cepas presentes en leche de ovino están genéticamente relacionadas con cepas aisladas de procesos humanos. El origen de la contaminación de la leche con cepas de aEPEC no está bien esclarecido, pero la similitud encontrada entre cepas procedentes de leche y agua sugieren una posible vía de contaminación a través del agua utilizada en la explotación, tanto el agua de bebida de los animales como el agua utilizada para la limpieza de los equipos. Robins-Browne et al. (2004) observaron que una importante causa de gastroenteritis humanas eran cepas de aEPEC presentes en el agua de bebida; por otro lado, García-Díez et al. (2009) encontraron que las características moleculares de aislados de aEPEC obtenidos de muestras de aguas superficiales eran similares a las 
detectadas en cepas procedentes de muestras humanas. Estos estudios, junto con los resultados que se presentan en este trabajo, sugieren que el agua puede constituir una ruta para la contaminación de la leche de ovino por cepas atípicas de EPEC.

En resumen, los resultados de este estudio sugieren que el agua de las explotaciones de ovino puede constituir una vía importante de contaminación de la leche por aEPEC. Además, la presencia en leche de ovino de cepas aEPEC relacionadas con otras causantes de enfermedad en humanos indica una posible ruta de transmisión de estos patógenos emergentes con el consiguiente riesgo para la salud. 
Capítulo III. Bibliografía

\section{BIBLIOGRAFÍA}

1. Afset, J. E., Anderssen, E., Bruant, G., Harel, J., Wieler, L. and Bergh, K. 2008.

Phylogenetic backgrounds and virulence profiles of atypical enteropathogenic

Escherichia coli strains from a case-control study using multilocus sequence typing and DNA microarray analysis. J. Clin. Microbiol., 46: 2280-2290.

2. Bandyopadhyay, S., Lodh, C., Rahaman, H., Bhattacharya, D., Bera, A., Ahmed, F., Mahanti, A., Samanta, I., Mondal, D. and Sarkar, S. 2012. Characterization of shiga toxin producing (STEC) and enteropathogenic Escherichia coli (EPEC) in raw yak (Poephagus grunniens) milk and milk products. Res. Vet. Sci., http://dx.doi.org/10.1016/i.rvsc.2011.12.011.

3. Blanco, M., Schumacher, S., Tasara, T., Zweifel, C., Blanco, J. E., Dahbi, G., Blanco, J. and Stephan, R. 2005. Serotypes, intimin variants and other virulence factors of eae positive Escherichia coli strains isolated from healthy cattle in Switzerland. Identification of a new intimin variant gene (eae-n2). BMC Microbiol., 5: 23.

4. Chen, H. D. \& Frankel, G. 2005. Enteropathogenic Escherichia coli: unravelling pathogenesis. FEMS Microbiol. Rev., 29: 83-98.

5. Franke, J., Franke, S., Schmidt, H., Schwarzkopf, A., Wieler, L. H., Baljer, G., Beutin, L. and Karch, H. 1994. Nucleotide sequence analysis of enteropathogenic Escherichia coli (EPEC) adherence factor probe and development of PCR for rapid detection of EPEC harboring virulence plasmids. J. Clin. Microbiol., 32: 2460-2463. 
6. García Díez, M., Meindl, K., Fräßdorf, J., Wolf, S., Schalch, B. and Busch, U. 2009. Prevalence of enteropathogenic Escherichia coli in food and water in Bavaria in 2007. Archiv für Lebensmittelhygiene, 5: 77-81.

7. Gunzburg, S. T., Tornieporth, N. G. and Riley, L. W. 1995. Identification of enteropathogenic Escherichia coli by PCR-based detection of the bundle-forming pilus gene. J. Clin. Microbiol., 33: 1375-1377.

8. Hernandes, R. T., Elias, W. P., Vieira, M. A. M. and Gomes, T. A. T. 2009. An overview of atypical enteropathogenic Escherichia coli. FEMS Microbiol. Lett., 297: 137-149.

9. Holko, I., Bisova, T., Holkova, Z. and Kmet, V. 2006. Virulence markers of Escherichia coli strains isolated from traditional cheeses made from unpasteurised sheep milk in Slovakia. Food Control, 17: 393-396.

10. Jolley, K. A., Feil, E. J., Chan, M. S. and Maiden, M. C. 2001. Sequence type analysis and recombinational tests (START). Bioinformatics, 17: 1230-1231.

11. Leomil, L., Pestana de Castro, A. F., Krause, G., Schmidt, H. and Beutin, L. 2005. Characterization of two major groups of diarrheagenic Escherichia coli $\mathrm{O} 26$ strains which are globally spread in human patients and domestic animals of different species. FEMS Microbiol. Lett., 249: 335-342.

12. Moura, R. A., Sircili, M. P., Leomil, L., Matté, M. H., Trabulsi, L. R., Elias, W. P., Irino, K. and de Castro, A. F. P. 2009. Clonal relationship among atypical enteropathogenic Escherichia coli strains isolated from different animal species and humans. Appl. Environ. Microbiol., 75: 7399-7408. 
13. Olsen, J. E., Aabo, S., Hill, W., Notermans, S., Wernars, K., Granum, P. E., Popovic, T., Rasmussen, H. N. and Olsvik, O. 1995. Proves and polymerase chain reaction for detection of food-borne bacterial pathogens. Int. J. Food Microbiol., 28: 1-78.

14. Oswald, E., Schmidt, H., Morabito, S., Karch, H., Marchès, O. and Caprioli, A. 2000. Typing of intimin genes in human and animal Enterohemorrhagic and Enteropathogenic Escherichia coli: caracterization of a new intimin variant. Infection and Immunity, 68: 64-71.

15. Pollard, D. R., Johnson, W. M., Lior, H., Tyler, S. D. and Rozee, K. R. 1990. Rapid and specific detection of Verotoxin genes in Escherichia coli by the Polymerase Chain Reaction. J. Clin. Microbiol., 28: 540-545.

16. Robins-Browne, R. M., Bordun, A., Tauschek, M., Bennett-Wood, V. R., Russell, J., Oppedisano, F., Lister, N. A., Bettelheim, K. A., Fairley, C. K. and Sinclair, M. I. 2004. Escherichia coli and community-acquired gastroenteritis, Melbourne, Australia. Emerging infectious diseases, 10: 1797.

17. Silva, Z. N., Cunha, A. S., Lins, M. C., Carneiro, L. A. M., Almeida, A. C. F. and Queiroz, M. L. P. 2001. Isolation and serological identification of enteropathogenic Escherichia coli in pasteurized milk in Brazil. Rev. Saúde Pública, 35: 375-379.

18. Tamura, K., Peterson, D., Peterson, N., Stecher, G., Nei, M., and Kumar, S. 2011. MEGA5: Molecular Evolutionary Genetics Analysis using maximum likelihood, evolutionary distance, and maximum parsimony methods. Mol. Biol. Evol., 28: 27312739. 
Capítulo III. Bibliografía

19. Trabulsi, L. R., Keller, R. and Gomes, T. A. T. 2002. Typical and atypical Enteropathogenic Escherichia coli. Emerg. Infect. Dis., 8: 508. 
Capítulo III. Bibliografía 
CAPÍTULO IV: Comportamiento de cepas de Escherichia coli productoras de toxinas Shiga

(STEC) en leche de oveja almacenada a diferentes

temperaturas y durante la elaboración y maduración de queso tipo Zamorano 



\section{INTRODUCCIÓN}

Se han publicado numerosos trabajos que estudian el comportamiento de microorganismos patógenos en leche y productos lácteos. En el caso de los grupos patógenos de Escherichia coli, la mayor parte de los estudios se centran en el serotipo O157:H7, siendo la información relativa a otros serogrupos y serotipos de STEC bastante limitada (Farrokh et al., 2013). Algunos de los parámetros que influyen en la multiplicación y supervivencia de STEC durante el almacenamiento de la leche y durante los procesos de elaboración y maduración de los quesos se revisan a continuación.

\section{TEMPERATURA}

Como ya se ha señalado en la Introducción general, la mayoría de las cepas de E. coli se multiplican en el rango $10-46$ ㄷ , presentando algunas de ellas capacidad para hacerlo a temperaturas de $8 \stackrel{\circ}{ } \mathrm{C}$. Ciertos serotipos de STEC pueden, incluso, crecer en leche a temperaturas tan bajas como 6,5 으. Se ha puesto de manifiesto que hay cepas de E. coli 0157 que poseen mecanismos genéticos que les permiten multiplicarse a temperaturas mínimas inferiores a las de cepas de E. coli no patógenos. Por otro lado, la supervivencia de este serogrupo parece ser mayor a bajas temperaturas $(2-5 \circ C)$ que a temperaturas superiores a 70 C (Erickson \& Doyle, 2007; Farrokh et al., 2013).

Las cepas de STEC no presentan una especial resistencia al calor en condiciones de $\mathrm{pH}$ neutro y actividad de agua $\left(\mathrm{a}_{\mathrm{w}}\right)$ moderadamente elevada ( $\mathrm{D}_{60}$ para $E$. coli O157:H7, 45 segundos), siendo, por tanto, inactivadas por los tratamientos HTST (“High Temperature Short Time" -72 으, 15 segundos-) de pasterización de la leche. Sin embargo, el estrés ambiental puede inducir termotolerancia en algunas cepas. Así, se ha observado que la exposición a calor suave o la protección cruzada inducida durante la adaptación al medio ácido aumentan la termotolerancia por la activación de genes de respuesta al estrés. Además, la grasa de los alimentos presenta un efecto protector frente a la inactivación térmica (Farrokh et al., 2013).

Por lo que respecta a las temperaturas utilizadas durante el proceso de maduración de los quesos, éstas no parecen ser un factor decisivo en la supervivencia 
de STEC puesto que algunos trabajos indican que E. coli 0157:H7 puede sobrevivir a una temperatura de $2{ }^{\circ} \mathrm{C}$ durante 60 o 75 días en quesos Camembert y Feta, respectivamente, y hasta 60 días a 7ํㅡ en queso Cheddar (Farrokh et al., 2013).

\section{2. $\mathrm{pH}$}

El pH óptimo para el crecimiento de cepas de E. coli O157:H7 se halla en valores próximos a 7 aunque hay cepas capaces de hacerlo en un rango que oscila entre 4,5 y 9. Por tanto, estos microorganismos encuentran un pH adecuado para su proliferación en la leche ( $\mathrm{pH}$ en torno a 6-7). Además, algunas cepas de E. coli 0157:H7 son acidorresistentes pudiendo llegar a tolerar valores de $\mathrm{pH}$ tan bajos como 2 o 3 (Welch, 2006; Farrokh et al., 2013); por tanto, su presencia en alimentos de acidez moderada, como por ejemplo algunos tipos de quesos, podría comprometer su inocuidad. Hay que recordar que, durante el proceso de elaboración del queso, las bacterias acidolácticas (BAL) producen ácidos orgánicos dando lugar a un descenso del pH hasta valores próximos a 4,5. La adaptación de E. coli 0157:H7 a la acidez del queso podría permitir también una mayor supervivencia de esta bacteria durante su paso por el ambiente ácido del estómago (Farrokh et al., 2013).

\section{CONCENTRACIÓN DE SAL Y $a_{w}$}

Durante la elaboración del queso existe una etapa de salado que se aplica para conseguir, entre otros fines, la disminución de la $a_{w}$ del producto y consecuentemente controlar el crecimiento microbiano. La $\mathrm{a}_{\mathrm{w}}$ mínima necesaria para la multiplicación de E. coli es de 0,945-0,950, por lo que este no será un factor limitante para el crecimiento de esta bacteria en leche aunque si en ciertas variedades de queso. Por otro lado, se ha comprobado que E. coli $\mathrm{O} 157: \mathrm{H} 7$ es inhibido completamente en medios líquidos con concentraciones de $\mathrm{NaCl} \geq 8,5 \mathrm{~g} / 100 \mathrm{~g}$, si bien podría multiplicarse después de $36 \mathrm{~h}$ de fase de latencia en presencia de concentraciones de 6,5 g/100 g (Jay et al., 2005).

\section{INTERACCIONES MICROBIANAS}

Tanto los microorganismos presentes en la leche como las BAL utilizadas como cultivo iniciador en la fabricación del queso son una competencia natural para la 
multiplicación de STEC. Aunque se conoce poco sobre los mecanismos por los que se produce esta interacción, se considera que entre estos se encuentran la producción por parte de las BAL de ácidos orgánicos, peróxido de hidrógeno, dióxido de carbono, diacetilo y bacteriocinas (Farrokh et al., 2013).

\section{OBJETIVO:}

Los objetivos del trabajo presentado en este Capítulo fueron tres: 1) investigar la resistencia de cepas STEC a diferentes valores de acidez, 2) determinar la evolución de cepas STEC en leche de oveja mantenida a diferentes temperaturas y 3 ) conocer el comportamiento de una cepa de E. coli O157:H7 durante el proceso de elaboración y maduración de un queso tipo Zamorano. 


\section{MATERIAL Y MÉTODOS}

\section{RESISTENCIA A LA ACIDEZ DE CEPAS STEC}

Un total de 50 cepas STEC (tres pertenecientes al serotipo 0157:H7 y 47 no0157:H7) procedentes de leche de tanque fueron estudiadas para determinar su resistencia a la acidez y, en función de ello, seleccionar las dos cepas más resistentes (una perteneciente al serotipo 0157:H7 y otra no-0157:H7) para los estudios posteriores.

Las cepas STEC aisladas de leche de tanque de explotaciones del Consorcio de Promoción del Ovino (CPO) se sembraron en placas de Sorbitol MacConkey Agar (SMAC, Oxoid, Basingstoke, UK) y fueron incubadas a $37{ }^{\circ} \mathrm{C}$ durante 24 horas. Transcurrido el tiempo de incubación, se tomó una colonia de cada una de las placas y se transfirió a tubos con caldo Tryptone Soya Broth (TSB, Oxoid) con un 0,3\% de ácido láctico (Panreac Química, S.L.U, Barcelona, España). Se utilizó un blanco de reacción sin microorganismo (caldo TSB + ácido láctico) y un control positivo sin ácido láctico (caldo TSB + cepa de E. coli). Se incubaron los tubos a $37^{\circ} \mathrm{C}$ y se midieron las absorbancias (620 nm) de los caldos después de 3, 6, 9 y 24 horas de incubación. Las lecturas se realizaron con un espectrofotómetro Multiskan FC microplate (Thermo Fisher Scientific Inc, Waltham, MA, USA).Todas las determinaciones se realizaron por duplicado.

\section{COMPORTAMIENTO DE CEPAS STEC EN LECHE CRUDA Y PASTERIZADA DE OVINO ALMACENADAS A DIFERENTES TEMPERATURAS}

Para este estudio se utilizaron las dos cepas seleccionadas en el apartado anterior (una perteneciente al serotipo 0157:H7 y otra STEC no-O157:H7).

La leche de oveja fue facilitada por la granja de la Universidad de León y transportada mediante una nevera isoterma hasta el laboratorio en menos de una hora. Se almacenó a refrigeración hasta su posterior uso. Una parte de esta leche fue sometida a una pasterización baja (LHT) manteniéndola a 63ํC durante 30 minutos. La otra parte no se trató térmicamente.

Se estudiaron muestras de leche, por triplicado, en las siguientes condiciones: 
- Leche cruda inoculada con E. coli O157:H7.

- Leche pasterizada inoculada con E. coli 0157:H7.

- Leche cruda inoculada con E. coli no-O157:H7.

- Leche pasterizada inoculada con E. coli no-O157:H7.

- Leche cruda no inoculada.

- Leche pasterizada no inoculada.

Las muestras inoculadas consistían en $20 \mathrm{ml}$ de leche con una concentración final de $c a .10^{2} \mathrm{ufc} / \mathrm{ml}$ de cada una de las cepas de STEC seleccionadas. Se eligió este nivel de inóculo teniendo en cuenta dos factores; por un lado, los bajos niveles de estas bacterias detectados en los muestreos descritos en el Capítulo I (fue necesario un enriquecimiento de las muestras para la obtención de aislados) y, por otro, la cantidad mínima de inóculo que permitía realizar recuentos.

Todas las muestras se almacenaron a diferentes temperaturas durante 5 días. Estas temperaturas se seleccionaron de acuerdo con las exigencias recogidas en el Reglamento (CE) № 853/2004 (Anónimo, 2004), por el que se establecen normas específicas de higiene de los alimentos de origen animal. Así, las temperaturas elegidas fueron:

- 6C: Temperatura máxima de la leche en granja si la recogida no es diaria.

- $\quad$ oㄷ: Temperatura máxima de la leche en granja si la recogida es diaria.

- 10C: Temperatura máxima de la leche durante el transporte al establecimiento de destino.

- Simulación de fallos en la cadena de frío. La secuencia de temperaturas y tiempos se detallan en la Figura IV.1. Se simuló un fallo en el mantenimiento de la temperatura durante la carga del camión cisterna para el transporte de la leche desde la granja al CPO, y otro fallo durante la carga de la leche para el transporte desde el CPO a la industria. 


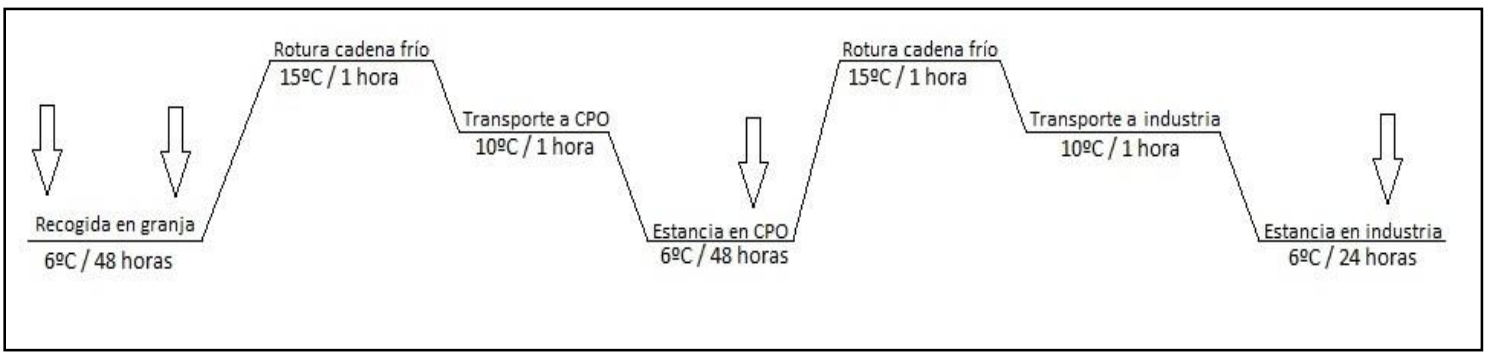

Figura IV.1. Secuencia de temperaturas y tiempos para la simulación de fallos en la cadena de frío de leche de ovino. Las flechas indican los puntos en los que se realizaron los análisis microbiológicos.

Las temperaturas utilizadas durante el almacenamiento de las muestras fueron controladas mediante el uso de un termómetro Testo 175-T2 (Instrumentos Testo, S.A., Cabrils, Barcelona). Éste termómetro fue programado para la toma de temperaturas cada 10 minutos con una precisión de $0,2 \circ \mathrm{C}$.

En cada una de las muestras se realizaron análisis microbiológicos para estudiar el desarrollo de las cepas STEC a tiempo 0, a las $48 \mathrm{~h}$ (momento de recogida de la leche en las explotaciones), a las $96 \mathrm{~h}$ (almacenamiento en el CPO) y $120 \mathrm{~h}$ (almacenamiento en la industria). Para el experimento de simulación de fallos en la cadena de frío, las mediciones se realizaron a tiempo 0, a las $46 \mathrm{~h}$ (antes de la carga de la leche en granja), a las $94 \mathrm{~h}$ (después del transporte y almacenamiento durante $41 \mathrm{~h}$ en el CPO) y $127 \mathrm{~h}$ (después del segundo fallo en la cadena de frío y durante el almacenamiento en la industria).

Para los análisis microbiológicos se realizaron diluciones y siembras en superficie $(100 \mu \mathrm{l})$ utilizando medios de cultivo diferentes en función de que fuera leche pasterizada o cruda. En las muestras de leche pasterizada, los análisis microbiológicos se realizaron utilizando placas de agar SMAC (Oxoid). Este medio era suficiente para el recuento de las cepas inoculadas una vez que la mayor parte de la microbiota inicial fue eliminada durante el proceso de pasterización. Por otro lado, en las muestras de leche cruda se utilizó CHROMagar ${ }^{\mathrm{TM}} 0157$ (Scharlab, Barcelona, España), medio específico para el aislamiento y diferenciación del serogrupo 0157, suplementado con Cefixima y Telurito (CT, Oxoid). Este medio cromogénico permitía diferenciar las colonias de E. coli 0157:H7 (color malva) de las de E. coli no-0157:H7 
(color azul metálico) de otras colonias originarias de la microbiota inicial de la leche cruda. Todas las placas fueron incubadas a $37^{\circ} \mathrm{C}$ durante 24 horas.

\section{COMPORTAMIENTO DE CEPAS STEC EN QUESO MADURADO DE OVEJA}

En primer lugar, se elaboraron quesos tipo Zamorano con las características y el método de elaboración indicado en el Reglamento de la Denominación de Origen “Queso Zamorano" (Anónimo, 1993). Según este, el queso Zamorano presentará las siguientes características una vez finalizada su maduración:

Forma: Cilíndrica con caras sensiblemente planas.

Altura: Hasta un máximo de 14 centímetros.

Diámetro: Hasta un máximo de 24 centímetros.

Peso: Hasta un máximo de 24 kilogramos.

Corteza: Dura, de color amarillo pálido o gris oscura y bien definida.

Pasta: Firme y compacta de color variable desde el blanco hasta el marfilamarillento, pudiendo presentar ojos pequeños o puntitos, repartidos por todo el corte. Aroma y sabores característicos, bien desarrollados e intensos, persistentes al paladar.

Grasa: No inferior al 45 por 100 sobre el extracto seco.

Extracto seco: Mínimo 55 por 100.

Proteína total: Mínimo 25 por 100.

pH: 5,1 a 5,8.

De este modo, se obtuvieron quesos a partir de leche cruda de ovino inoculada con la cepa de E. coli 0157:H7 seleccionada (lote 1), y quesos con las mismas características a partir de leche sin inocular (lote 2). En todos los quesos elaborados se estudió la evolución de los parámetros $\mathrm{pH}, \mathrm{a}_{\mathrm{w}} \mathrm{y}$ contenido en sal a lo largo de su proceso de elaboración y maduración. Para cada tipo de queso, a partir de leche inoculada y sin inocular, la fabricación se realizó por triplicado.

Para la elaboración de cada lote se utilizaron 12 litros de leche cruda de ovino procedente de la granja de la Universidad de León. El proceso de elaboración fue el mismo en ambos lotes (Figura IV.2), salvo que la leche del lote 1 se contaminó 
intencionadamente con una concentración final de ca. $10^{3} \mathrm{ufc} / \mathrm{ml}$ de la cepa seleccionada. Este nivel de inoculo fue elegido considerando el nivel máximo de $E$. coli 0157:H7 que se podría detectar ("peor escenario posible" en carne picada y en leche) (ICMSF, 2002; Schlesser et al., 2006).

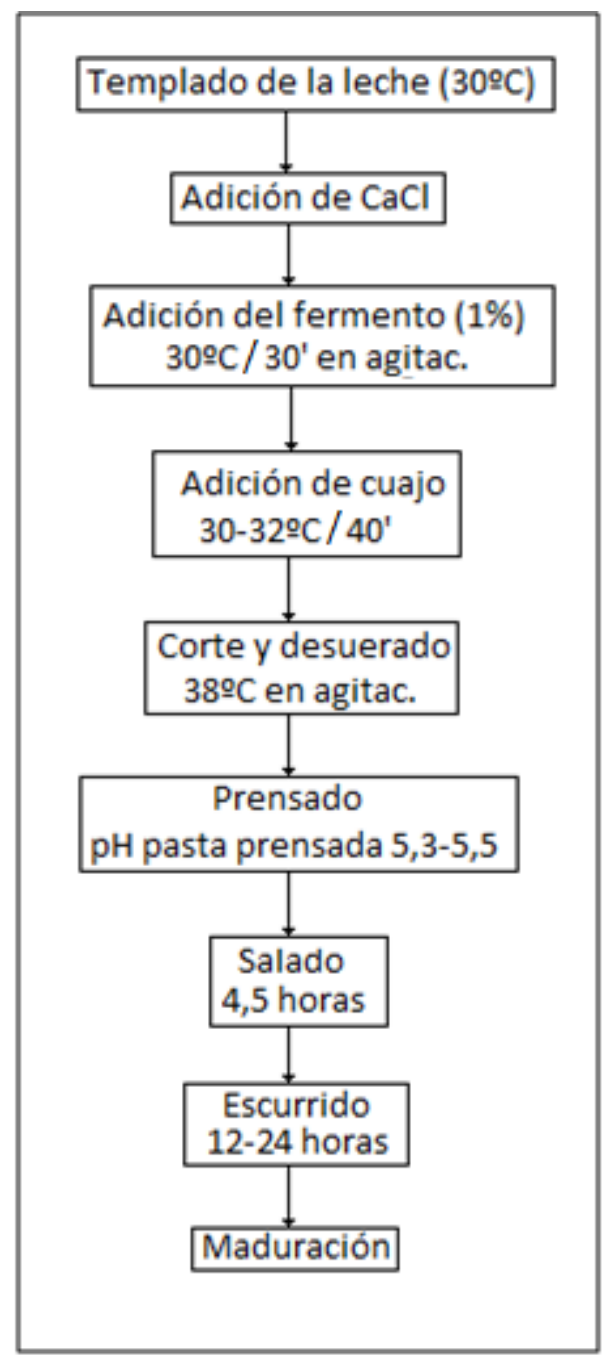

Figura IV.2. Diagrama de flujo del proceso seguido para la de elaboración de queso tipo Zamorano.

El proceso de elaboración de los quesos que se representa en la Figura IV.2 consistió en las siguientes etapas:

- Precalentamiento de la leche a 30ㄷ con agitación continua y medición del pH (Testo 205, Instrumentos Testo).

- Adición de cloruro cálcico (Laboratorios Arroyo, Peñacastillo, Santander, España) en proporción de 1 I de producto en 8000 I de leche sin pasterizar. 
- Adición del cultivo iniciador (Danisco Choozit MA4001 LYO 05DCU, Danisco, Sassenage, Francia) en concentración del 1\%. Se permitió su actuación durante unos 30 minutos a $30 \circ \mathrm{C}$ hasta que el $\mathrm{pH}$ descendió en 0,1 unidades. El fermento se preparó disolviendo en leche y se conservó a 32ำ durante toda la noche para su utilización al día siguiente.

- Adición de cuajo diluido en agua para obtener una concentración de 1:10.000 (Laboratorios Arroyo). Se mantuvo a 30-32ำ durante unos 40 minutos hasta la formación óptima de la cuajada (suero claro y al cortarla en forma de T se levantaba entera).

- Desuerado: se cortó y agitó la cuajada hasta conseguir trozos del tamaño de un "grano de arroz", aumentando la temperatura simultáneamente hasta que se alcanzaron $38^{\circ} \mathrm{C}$.

- Prensado: se sacaron los granos de cuajada separados del suero y se introdujeron en tres moldes para posteriormente prensar hasta que el pH llegó a 5,5 aproximadamente. Se realizó un primer prensado durante 40 minutos, volteando los quesos para llevar a cabo un segundo prensado más intenso durante las siguientes nueve horas.

- Salado: en una salmuera con un $20 \%$ de sal, añadiendo ácido láctico hasta que el pH alcanzó un valor similar al de los quesos. Se mantuvo en la salmuera durante 4 horas y media a $8-10 \stackrel{\circ}{ }$. Se voltearon los quesos transcurrida la mitad del tiempo de salado.

- Escurrido: a temperatura ambiente durante 12-24 horas.

- Maduración, en las condiciones siguientes:

○ Temperatura: $10-12^{\circ} \mathrm{C}$

O HR: $85-90 \%$

- Tiempo: 2 meses (periodo mínimo de maduración para quesos elaborados con leche cruda de la especie ovina en zonas geográficas no oficialmente indemnes de brucelosis según el Real Decreto 640/2006) (Anónimo, 2006). Durante la maduración se voltearon los quesos regularmente para conseguir una distribución homogénea de la sal. 
Se realizaron los recuentos de la cepa de E. coli $0157: \mathrm{H} 7$ y de bacterias BAL a lo largo del proceso de elaboración de los quesos. También se midieron el pH y la $\mathrm{a}_{\mathrm{w}}$. Todos estos parámetros fueron obtenidos en los siguientes puntos:

- Inicialmente en la leche cruda. En este punto no se realizó el recuento de BAL.

- Una vez separada la cuajada del suero, después del primer prensado.

- Después del salado.

- Una vez finalizado el escurrido.

- A las 24 horas, una semana, un mes y dos meses del comienzo de la maduración.

Además, después de la etapa de salado, se realizaron mediciones del contenido en sal en estas mismas fases.

Para el recuento de E. coli O157:H7 se procedió de diferente modo en función de la matriz alimentaria:

a) A partir de la leche se realizó una siembra directa en superficie $(100 \mu l)$ en el medio CHROMagar ${ }^{\mathrm{TM}} \mathrm{O} 157$ (Scharlab).

b) En el caso de la cuajada y el queso, se tomaron $10 \mathrm{~g}$ del producto y se homogeneizaron en un BagMixer-400 blender (Interscience, Saint-Nom-laBretèche, Francia) durante un minuto con $40 \mathrm{ml}$ de TSB (Oxoid) con Yeast Extract (YE, Oxoid) al 0,6\%. A partir de las correspondientes diluciones decimales, se sembraron alícuotas de $400 \mu$ l en la superficie de placas (150 $\mathrm{mm}$ de diámetro) de CHROMagar. De esta manera se amplió el límite de detección hasta 6,25 ufc/g.

Las placas de CHROMagar se incubaron a $37^{\circ} \mathrm{C}$ durante 24 horas y posteriormente se realizó el recuento de las colonias expresando el resultado en $\mathrm{ufc} / \mathrm{ml}$ o ufc/g según correspondía. El homogeneizado inicial además se incubó a 42 ㄷ durante toda la noche para, en caso de que no se detectara ninguna colonia en las placas de cultivo, comprobar la supervivencia de la cepa por siembra a partir de este enriquecimiento en nuevas placas de CHROMagar. 
Para el recuento de las BAL, partiendo del homegeneizado para la determinación de E. coli 0157:H7, se realizaron las oportunas diluciones decimales desde las que se sembraron en profundidad $(1 \mathrm{ml})$ placas de medio "Agar Man, Rogosa y Sharpe" (MRS, Oxoid) con sobrecapa final del mismo medio de cultivo. Posteriormente se incubaron las placas a $30^{\circ} \mathrm{C}$ durante 48 horas. Una vez trascurrido el tiempo de incubación se realizó el recuento de las colonias expresando el resultado en ufc/g.

La medición del pH se realizó con un pHmetro de punción (Testo 205, Instrumentos Testo) en los puntos señalados anteriormente.

En el caso de la determinación de la $\mathrm{a}_{\mathrm{w}}$, se utilizó el equipo AquaLab modelo CX2 (Decagon, Pullman, WA, USA). Se colocaron las muestras en los recipientes facilitados por el fabricante cubriendo completamente el fondo y no sobrepasando la mitad de su capacidad. Se introdujeron estas muestras en el aparato a temperatura ambiente y se procedió a su lectura.

Finalmente, se determinó el contenido de $\mathrm{NaCl}$ mediante el método oficial de determinación de cloruros en queso descrito por Vohlard según la Norma AOAC 935.43 (Bradley, 2006) . El proceso consistió en lo siguiente:

- En un matraz de $250 \mathrm{ml}$ se pesaron 3 gramos de queso, añadiendo a continuación $25 \mathrm{ml}$ de nitrato de plata 0,1N (Panreac Química) y $25 \mathrm{ml}$ de ácido nítrico al 60\% (Panreac Química).

- Se agitó la mezcla y se llevó a ebullición, añadiendo a continuación y muy lentamente $15 \mathrm{ml}$ de una solución saturada de permanganato potásico (Panreac Química).

- Se retiró el matraz del fuego y se añadieron $100 \mathrm{ml}$ de agua destilada y $2 \mathrm{ml}$ de una solución saturada de sulfato férrico-amónico (Panreac Química), mezclando el contenido adecuadamente.

- Finalmente, se valoró el exceso de nitrato de plata con una solución de tiocianato potásico 0,1 N (Panreac Química) hasta la aparición de un color pardo-rojizo persistente durante 30 segundos. 
- Se efectuó el ensayo de un blanco con agua destilada siguiendo el proceso descrito, exceptuando la incorporación del permanganato potásico utilizado para la digestión de la materia orgánica.

\section{ANÁLISIS ESTADÍSTICO}

Los resultados obtenidos fueron procesados con el programa informático "Statistica for Windows v. 7" (Statsoft Inc., Tulsa, OK, USA, www.statsoft.com). Se calcularon los valores promedios y las desviaciones estándar. Los recuentos microbianos (ufc/ml o ufc/g) fueron previamente transformados y expresados como $\log _{10} \mathrm{ufc} / \mathrm{ml}$ o $\log _{10} \mathrm{ufc} / \mathrm{g}$.

Se estimó la relación lineal entre los parámetros investigados en los diferentes experimentos utilizando un análisis multifactorial de la varianza (ANOVA): (a) entre las cepas STEC, el tiempo y los valores de absorbancia (resistencia a la acidez); (b) entre el tipo de tratamiento aplicado a la leche, la temperatura de conservación, el tiempo de almacenamiento y las cepas objeto de estudio (almacenamiento de la leche); (c) entre los valores de $\mathrm{pH}, \mathrm{a}_{\mathrm{w}}$ y contenido en sal, y los recuentos de BAL y E. coli 0157:H7 durante la elaboración y maduración (tiempo de almacenamiento) de quesos tipo Zamorano.

Finalmente, se llevaron a cabo comparaciones por pares "post-hoc" de las medias mediante la prueba de Fisher de la menor diferencia significativa (Fisher's Least Significant Difference test). 


\section{RESULTADOS}

\section{RESISTENCIA A LA ACIDEZ DE CEPAS STEC}

En primer lugar se estudió la resistencia a la acidez de las tres cepas de $E$. coli 0157:H7 (Figura IV.3). Se apreciaron diferencias significativas $(p<0,05)$ entre los valores de absorbancia registrados a lo largo del tiempo. Estos valores fueron significativamente mayores ( $p<0,05$ ) para la cepa M240VO que para las cepas M462VO y M364VO a partir de 6 y 21 horas de incubación, respectivamente. Desde un punto de vista estadístico, las diferencias observadas en las absorbancias determinadas en las cepas M462VO y M364VO no fueron significativas ( $p>0,05$ ). Por tanto, la cepa M240VO fue seleccionada para las pruebas de comportamiento en leche y queso de oveja en base a su mayor resistencia a la acidez.

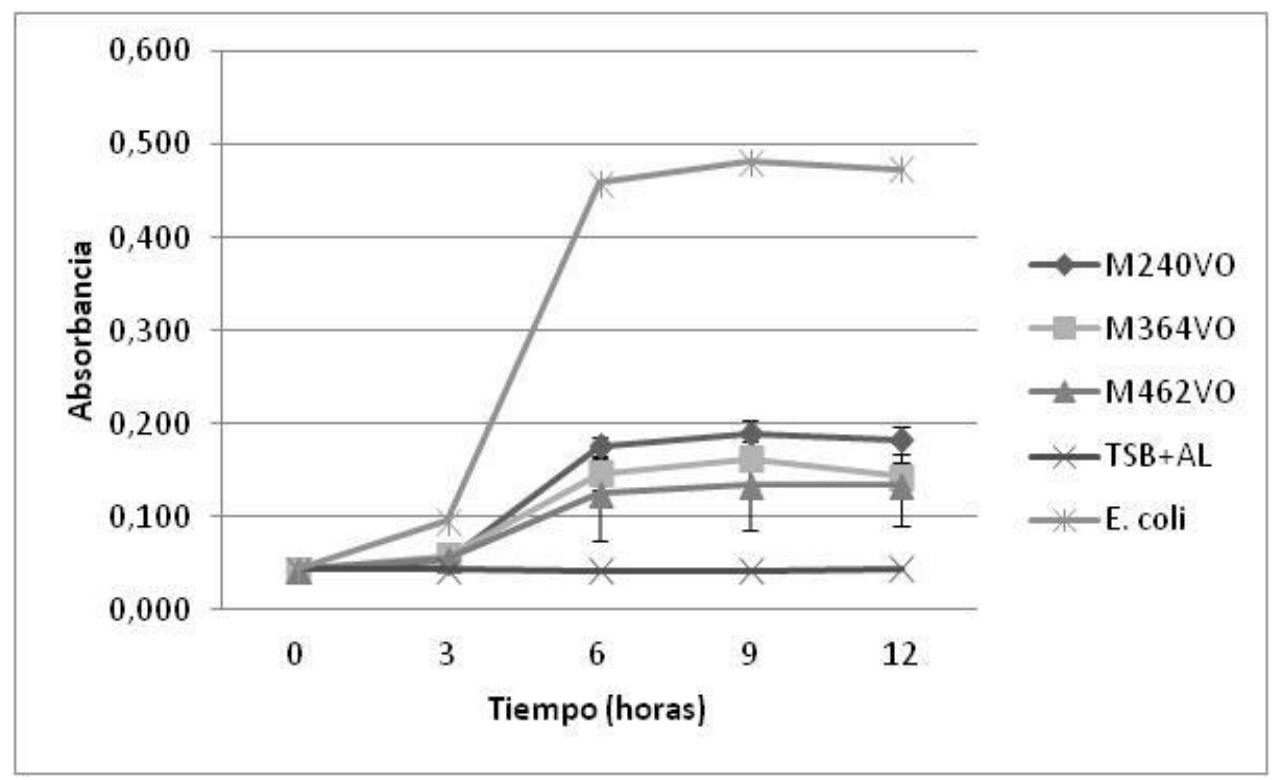

Figura IV.3. Evolución de los valores de absorbancia a $620 \mathrm{~nm}$ de cepas de E. coli 0157:H7. TSB+AL, blanco de reacción (caldo TSB + ácido láctico 0,3\%); E. coli, control positivo (caldo TSB sin ácido láctico).

En el caso de las cepas de E. coli no-O157:H7, la resistencia a la acidez determinada por la absorbancia observada (Figura IV.4), no difirió significativamente cuando se comparaba la cepa M294bVO con la siguiente más resistente (cepa M511VO). Sin embargo, a partir de seis horas de incubación los valores registrados de absorbancia para la cepa M294bVO se diferenciaron de aquéllos obtenidos en el resto 
de cepas de E. coli no-0157:H7, mostrando así mayor resistencia a la acidez y siendo, por tanto, seleccionada para las posteriores pruebas de comportamiento.

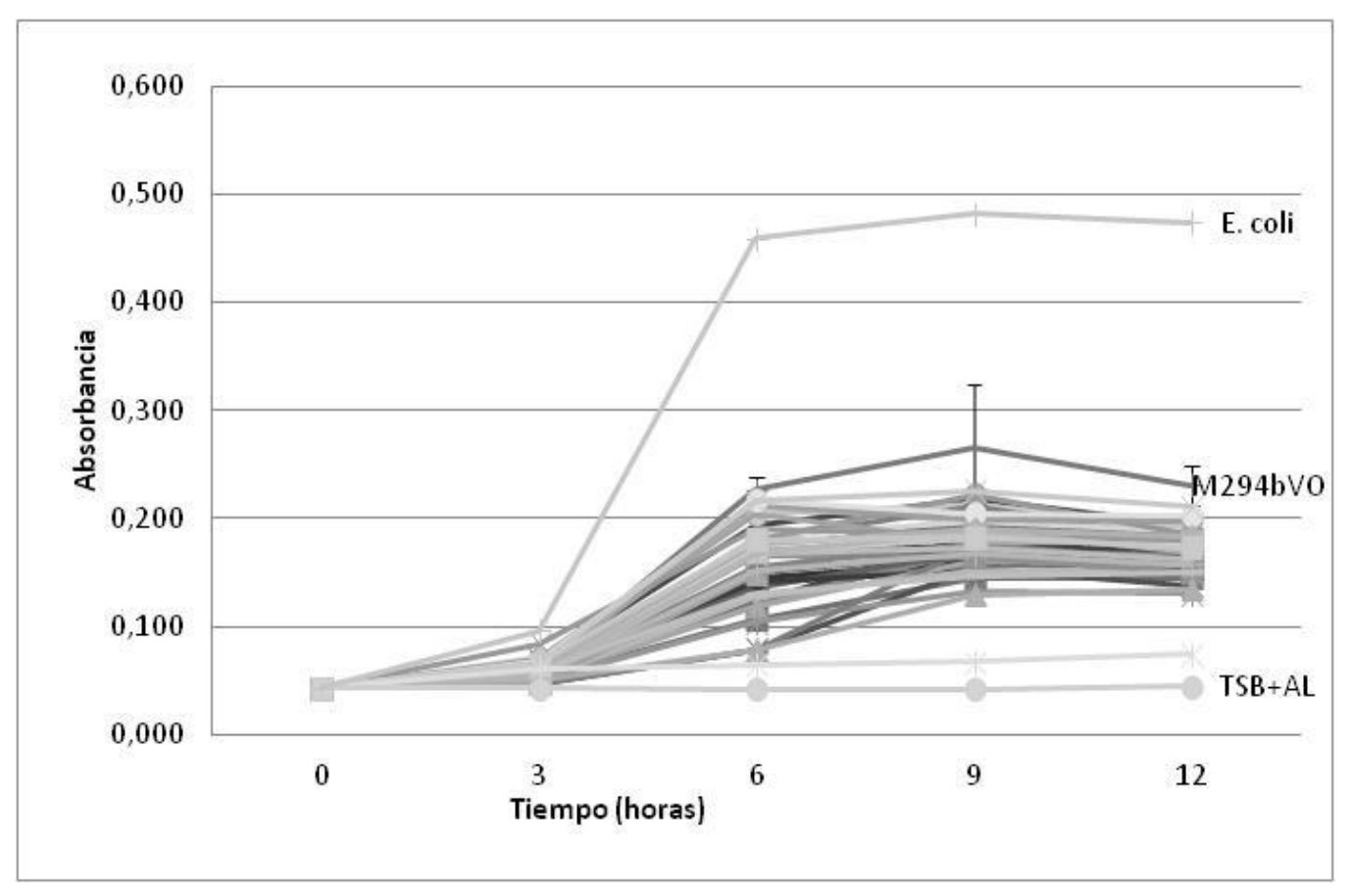

Figura IV.4. Evolución de los valores de absorbancia $620 \mathrm{~nm}$ de cepas E. coli no0157:H7. TSB+AL, blanco de reacción (caldo TSB + ácido láctico 0,3\%); E. coli, control positivo (caldo TSB sin ácido láctico).

\section{COMPORTAMIENTO DE CEPAS STEC EN LECHE CRUDA Y PASTERIZADA DE OVINO ALMACENADAS A DIFERENTES TEMPERATURAS}

La monitorización de las temperaturas de almacenamiento ( $6 \circ \mathrm{C}, 8^{\circ} \mathrm{C}$ y 10 으) mostró variaciones muy pequeñas, en el rango de $0,1-0,4$ 으 $\mathrm{C}$, mientras que en el caso del almacenamiento a 15으 la variación fue mayor (de hasta 0,7 으). Las desviaciones estándar de los registros obtenidos se encontraron entre $\pm 0,05$ y $\pm 0,14$. Por tanto, las temperaturas a las que fueron almacenadas las muestras se mantuvieron bastantes constantes y cercanas a las temperaturas nominales.

A partir de la selección de cepas realizada en el experimento anterior, se estudió el comportamiento de las cepas M240VO (E. coli O157:H7) y M294bVO (E. coli no-0157:H7) en leche cruda y LHT durante el almacenamiento a diferentes 
temperaturas de refrigeración y en simulación de fallos de mantenimiento de la cadena de frío, cuyo resultados se presentan en la Tabla IV.1.

Los factores tratamiento de la leche, temperatura y tiempo de almacenamiento tuvieron un efecto significativo $(p<0,05)$ sobre los recuentos de las cepas. En general, el comportamiento de ambas fue similar, no observándose diferencias significativas.

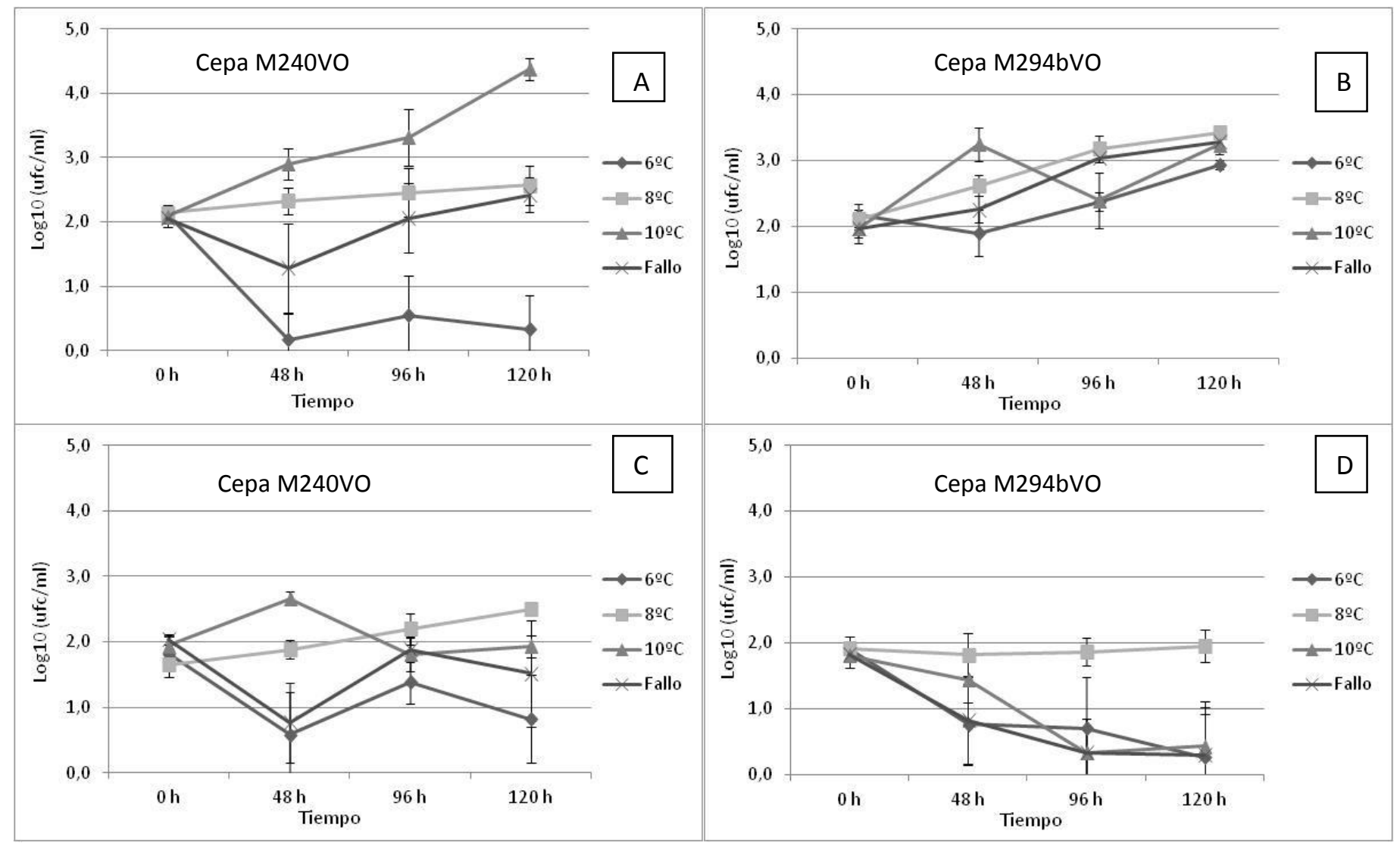

Figura IV.5. Evolución de los recuentos de cepas STEC en leche LHT (63ํㄷ/30 minutos) ( $A$ y $B$ ) y cruda (C y D). 
Tabla IV.1. Comportamiento de dos cepas STEC (M240VO -E. coli O157:H7- y M294bVO -E. coli no-O157:H7-) en muestras de leche de oveja LHT (63ㄷ/30 minutos) y cruda almacenadas a diferentes temperaturas.

\begin{tabular}{|c|c|c|c|c|c|c|c|c|c|}
\hline \multirow{3}{*}{ LECHE } & \multirow{3}{*}{ Tạ } & \multicolumn{8}{|c|}{ RECUENTO ( $\log _{10}$ ufc / ml) } \\
\hline & & \multicolumn{4}{|c|}{ Cepa M240VO } & \multicolumn{4}{|c|}{ Cepa M294bVO } \\
\hline & & $\mathbf{O h}$ & $48 \mathrm{~h}$ & $96 \mathrm{~h}$ & $120 \mathrm{~h}$ & $\mathbf{O h}$ & $48 \mathrm{~h}$ & $96 \mathrm{~h}$ & $120 \mathrm{~h}$ \\
\hline \multirow{4}{*}{$\mathbf{L H T}^{\mathrm{C}}$} & $6 \circ \mathrm{C}$ & ${ }^{\mathrm{a}} 2,13 \pm 0,09^{1 \mathrm{~b}}$ & $0,17 \pm 0,41^{2}$ & $0,55 \pm 0,61^{2}$ & $0,33 \pm 0,52^{2}$ & $2,17 \pm 0,17^{1}$ & $1,90 \pm 0,35^{1}$ & $2,38 \pm 0,15^{2}$ & $2,94 \pm 0,07^{3}$ \\
\hline & 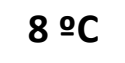 & $2,14 \pm 0,12^{1}$ & $2,33 \pm 0,21^{1}$ & $2,45 \pm 0,38^{1}$ & $2,57 \pm 0,30^{1}$ & $2,10 \pm 0,15^{1}$ & $2,62 \pm 0,16^{2}$ & $3,18 \pm 0,20^{3}$ & $3,43 \pm 0,05^{3}$ \\
\hline & $10 \div \mathrm{C}$ & $2,08 \pm 0,16^{1}$ & $2,90 \pm 0,25^{2}$ & $3,31 \pm 0,44^{2}$ & $4,37 \pm 0,17^{3}$ & $1,97 \pm 0,14^{1}$ & $3,25 \pm 0,25^{2}$ & $2,40 \pm 0,42^{3}$ & $3,24 \pm 0,15^{4}$ \\
\hline & Fallo $^{d}$ & $2,06 \pm 0,07^{1}$ & $1,28 \pm 0,70^{2}$ & $2,06 \pm 0,54^{3}$ & $2,42 \pm 0,27^{3}$ & $1,96 \pm 0,21^{1}$ & $2,26 \pm 0,20^{1}$ & $3,04 \pm 0,06^{2}$ & $3,29 \pm 0,08^{2}$ \\
\hline \multirow{4}{*}{ Cruda } & $6 \circ \mathrm{C}$ & $1,82 \pm 0,26^{1}$ & $0,58 \pm 0,66^{2}$ & $1,38 \pm 0,33^{3}$ & $0,82 \pm 0,67^{4}$ & $1,92 \pm 0,12^{1}$ & $0,77 \pm 0,61^{2}$ & $0,70 \pm 0,78^{2}$ & $0,27 \pm 0,65^{3}$ \\
\hline & 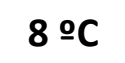 & $1,65 \pm 0,19^{1}$ & $1,88 \pm 0,15^{1}$ & $2,20 \pm 0,24^{1}$ & $2,49 \pm 0,06^{1}$ & $1,92 \pm 0,17^{1}$ & $1,82 \pm 0,34^{1}$ & $1,87 \pm 0,21^{1}$ & $1,95 \pm 0,24^{1}$ \\
\hline & $10 \div C$ & $1,94 \pm 0,15^{1}$ & $2,66 \pm 0,10^{2}$ & $1,80 \pm 0,25^{3}$ & $1,93 \pm 0,17^{3}$ & $1,81 \pm 0,18^{1}$ & $1,44 \pm 0,35^{1}$ & $0,33 \pm 0,52^{2}$ & $0,43 \pm 0,67^{2}$ \\
\hline & Fallo & $2,04 \pm 0,08^{1}$ & $0,77 \pm 0,61^{2}$ & $1,88 \pm 0,20^{3}$ & $1,52 \pm 0,81^{3}$ & $1,82 \pm 0,11^{1}$ & $0,83 \pm 0,67^{2}$ & $0,33 \pm 0,52^{3}$ & $0,30 \pm 0,73^{3}$ \\
\hline
\end{tabular}

${ }^{\text {a }}$ Cada media \pm desviación estándar representa el promedio de seis recuentos microbianos.

${ }^{\mathrm{b}}$ En cada fila y para cada temperatura de almacenamiento y cepa estudiada, superíndices diferentes en cada valor respecto al inmediatamente anterior indican diferencias significativas $(p<0,05)$.

${ }^{c} \mathrm{LHT}$, leche pasteurizada a baja temperatura (63ㅇ $/ 30 \mathrm{~min}$ ).

${ }^{\mathrm{d}}$ Fallo, simulación de falta de mantenimiento de la cadena de frío. 
Los recuentos de las cepas estudiadas al final del almacenamiento fueron significativamente mayores en las muestras de leche pasterizada (Figura IV.5 A y B) que en las de leche cruda (Figura IV.5 C y D). En particular, los niveles de la cepa no0157:H7 (M294bVO) fueron significativamente mayores en leche LHT a todas las temperaturas de almacenamiento $\left(6 \circ \mathrm{C}, 8{ }^{\circ} \mathrm{C}, 10^{\circ} \mathrm{C}\right.$ y fallo en la cadena de frío), incrementándose éstos en $0,77 \mathrm{log} \mathrm{ufc} / \mathrm{ml}$ a 6 o C y en aproximadamente 1,30 log $\mathrm{ufc} / \mathrm{ml}$ en el resto de temperaturas. Además, excepto a $6 \stackrel{\circ}{\circ}$, el aumento de los recuentos se produjo a las $48 \mathrm{~h}$ de almacenamiento. En el caso de la cepa 0157:H7 (M240VO) inoculada en leche LHT, solo se observaron incrementos significativos durante el almacenamiento a $10^{\circ} \mathrm{C}$ y en la simulación de fallo en la cadena de frío (Tabla IV.1).

En leche cruda y para ambas cepas, el efecto de las temperaturas de refrigeración fue mucho más acusado que en leche LHT, incluso en las condiciones simuladas de fallo en la cadena de producción de frío. En este caso, la cepa M294bVO (no-0157:H7) se mostró más sensible, reduciéndose sus números a valores tan bajos

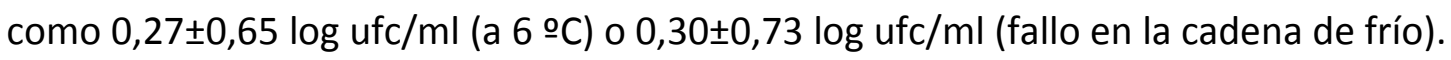

Para la cepa M240VO (O157:H7), tanto en leche LHT como en leche cruda, y para la cepa M294bVO (no-O157:H7) en leche cruda, el almacenamiento a 6으 no permitió su crecimiento.

\section{COMPORTAMIENTO DE CEPAS STEC EN QUESO TIPO ZAMORANO}

Los resultados obtenidos para los parámetros físico-químicos y microbiológicos a lo largo del proceso de elaboración de quesos tipo Zamorano con leche cruda de ovino se presentan en la Tabla IV.2.

El proceso de elaboración y maduración de los quesos fue bastante homogéneo entre las diferentes réplicas realizadas tal y como reflejan las desviaciones estándar de los valores obtenidas para los diferentes parámetros estudiados (Tabla IV.2). 
Tabla IV.2. Evolución de diferentes parámetros físico-químicos y microbiológicos en el proceso de elaboración y maduración de queso tipo Zamorano fabricado con leche cruda de oveja inoculada con la cepa de E. coli 0157:H7 M240VO.

\begin{tabular}{lccccc}
\hline \multicolumn{1}{c}{ FASE DE PRODUCCIÓN } & $\mathbf{p H}$ & $\mathbf{a}_{\mathbf{w}}$ & $\mathbf{N a C l}$ & $\begin{array}{c}\mathbf{B A L}^{\text {a }} \\
\text { (ufc/g) }\end{array}$ & $\begin{array}{c}\text { Cepa M240VO } \\
\text { (ufc/g) }\end{array}$ \\
\hline Leche & $\mathrm{b}^{\mathrm{b}} 6,51 \pm 0,01$ & $1,000 \pm 0,001$ & $\mathrm{ND}^{\mathrm{c}}$ & $\mathrm{ND}$ & $2,79 \pm 0,09^{\mathrm{d}}$ \\
Cuajada & $6,41 \pm 0,01$ & $0,996 \pm 0,001$ & $\mathrm{ND}$ & $8,17 \pm 0,18$ & $3,43 \pm 0,21$ \\
Tras salado & $5,41 \pm 0,02$ & $0,985 \pm 0,003$ & $1,73 \% \pm 0,00$ & $9,40 \pm 0,06$ & $3,72 \pm 0,05$ \\
Tras escurrido & $5,38 \pm 0,03$ & $0,980 \pm 0,003$ & $1,71 \% \pm 0,00$ & $9,38 \pm 0,16$ & $3,73 \pm 0,05$ \\
24 h maduración & $5,34 \pm 0,01$ & $0,976 \pm 0,001$ & $1,60 \% \pm 0,00$ & $9,36 \pm 0,07$ & $3,17 \pm 0,26$ \\
1 semana maduración & $5,35 \pm 0,03$ & $0,967 \pm 0,002$ & $1,67 \% \pm 0,00$ & $9,17 \pm 0,09$ & $2,95 \pm 0,27$ \\
1 mes maduración & $5,32 \pm 0,01$ & $0,962 \pm 0,002$ & $1,70 \% \pm 0,00$ & $9,34 \pm 0,02$ & $0,98 \pm 0,32$ \\
2 meses maduración & $5,30 \pm 0,01$ & $0,955 \pm 0,001$ & $1,94 \% \pm 0,00$ & $9,27 \pm 0,10$ & $0,80 \pm 0,00$ \\
\hline
\end{tabular}

${ }^{\mathrm{a}} \mathrm{BAL}$, bacterias acidolácticas

${ }^{\mathrm{b}}$ Cada media \pm desviación estándar representa el promedio de seis resultados.

${ }^{\mathrm{c}} \mathrm{ND}$ : No determinado

${ }^{d}$ Recuento de la cepa M240VO expresado en ufc/ml

Los valores de $\mathrm{pH}$ y $\mathrm{a}_{\mathrm{w}}$ fueron disminuyendo a lo largo del proceso (hasta $5,34 \pm 0,01$ y 0,976 $\pm 0,001$ a las $24 \mathrm{~h}$ de maduración, respectivamente), mientras que la concentración de sal experimentó pequeñas fluctuaciones (alrededor de $\pm 0,13 \%$ ) para finalmente aumentar hasta un valor de 1,94\% de $\mathrm{NaCl}$ al final de la maduración. De hecho, se pudo observar que existía una correlación inversa $(p<0,05)$ de la concentración de sal con respecto al pH $(r=-0,99)$ y a la $a_{w}(r=-0,82)$. Estos resultados siguen la tendencia esperada en el proceso de elaboración y maduración de cualquier queso de oveja de este tipo.

Los recuentos de BAL aumentaron significativamente durante el prensado y salado de los quesos (+1,23 log ufc/g). A partir de este momento, su nivel se mantuvo bastante estable (Figura IV.6) hasta el final del proceso $(9,27 \pm 0,10 \mathrm{log}$ ufc/g).

Durante las primeras etapas de la elaboración de los quesos, los recuentos de la cepa M240VO de E. coli O157:H7 aumentaron desde una concentración inicial de

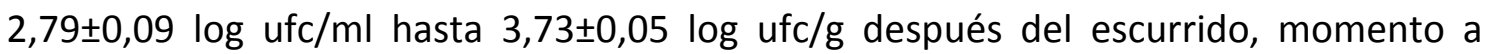
partir del cual su nivel empezó a descender hasta el primer mes de maduración $(0,98 \pm 0,32 \log u f c / g)$, manteniéndose estos números sin diferencias significativas hasta el fin del estudio (Figura IV.6). 
Se observó una correlación directa entre los recuentos de la cepa M240VO y la $a_{w}$, no existiendo correlación con el resto de parámetros fisicoquímicos o con los recuentos de BAL.

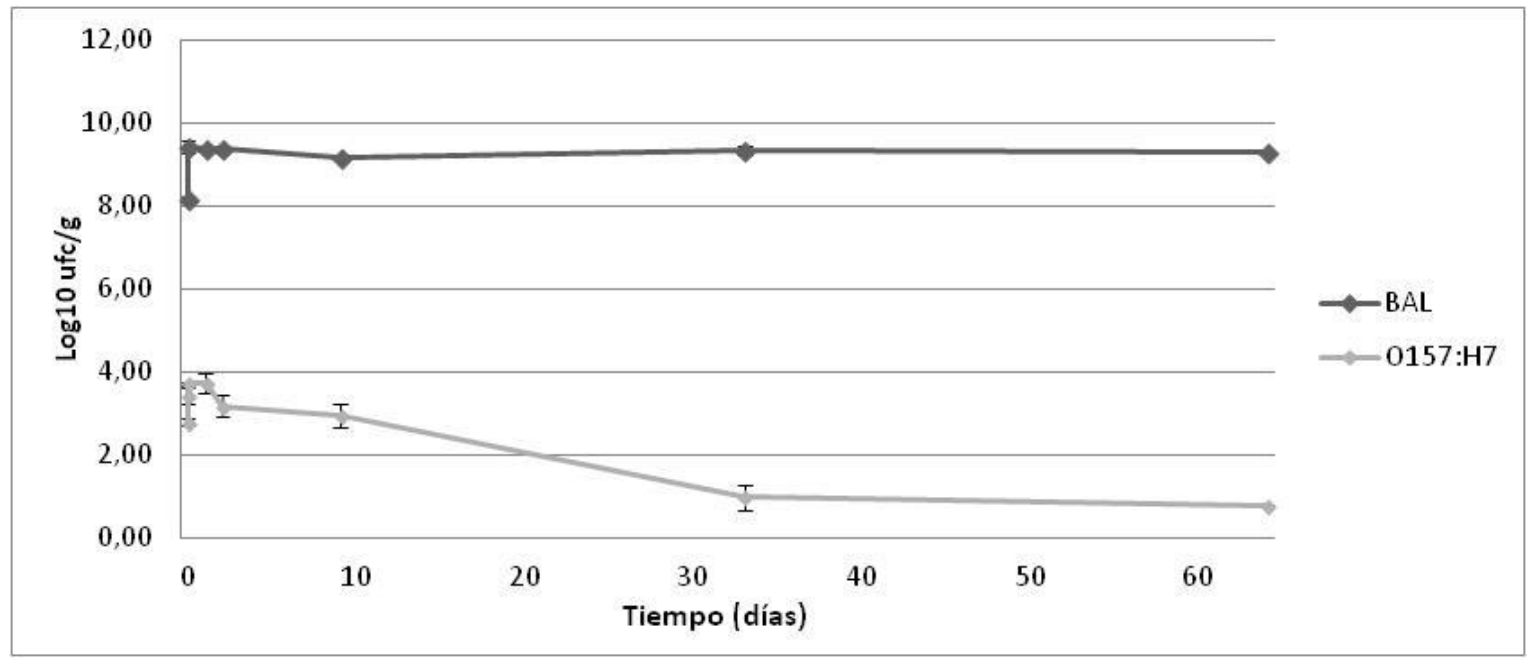

Figura IV.6. Evolución a lo largo del proceso de elaboración y maduración de quesos de leche cruda de ovino (tipo Zamorano) de los recuentos de BAL (bacterias acidolácticas) y E. coli 0157:H7 (cepa M240VO). 


\section{DISCUSIÓN}

La presencia de cepas STEC en leche y productos lácteos, tanto de ovino como de otras especies ha sido detectada frecuentemente. Así, se han publicado numerosos trabajos en los que se han aislado estas cepas tanto de leche (Dontorou et al., 2003; Muehlherr et al., 2003; Caro et al., 2006; Rey et al., 2006; D'Amico et al., 2008; Solomakos et al., 2009; Martin \& Beutin, 2011) como de diversas variedades de quesos (Vernozy-Rozand et al., 2005; Holko et al., 2006; Rey et al., 2006; Caro \& GarcíaArmesto, 2007; Mora et al., 2007; Martin \& Beutin, 2011; Elhadidy \& Mohammed, 2012; Farrokh et al., 2013). Estos hallazgos y algunos datos epidemiológicos ponen de manifiesto el posible riesgo asociado a la presencia de STEC en quesos y otros productos lácteos elaborados con leche cruda (Baylis, 2009; Farrokh et al., 2013).

La importancia de las cepas STEC como agentes de enfermedades de transmisión alimentaria es indudable. Además de sus factores de virulencia y el hecho de que los animales lecheros portadores no presenten síntomas clínicos, destaca su baja dosis infectiva (entre 10 y 100 células) y su resistencia a la acidez (Kaper et al., 2004; Welch, 2006; Elizaquível et al., 2011). Durante la elaboración de muchas variedades de quesos, el pH desciende aproximadamente desde 6,7 a 5,2 debido a la actividad metabólica de las BAL, aunque en algunos tipos este descenso puede ser mayor, como en los quesos de coagulación ácida o en el Camembert que pueden llegar hasta 4,3 y 4,6 respectivamente (Peng et al., 2011). E. coli 0157:H7 se multiplica en el intervalo de $\mathrm{pH}$ comprendido entre 4,5 y 9 pero algunas cepas lo hacen a $\mathrm{pH}$ tan bajos como 2 ó 3 (Welch, 2006; Farrokh et al., 2013). Creemos que todo lo expuesto, justifica la primera parte de este estudio ya que se pretendía seleccionar las cepas más resistentes a la acidez para observar su comportamiento durante la fabricación del queso tipo Zamorano.

En las pruebas de comportamiento de cepas STEC en leche cruda y pasterizada (LHT) mantenidas a diferentes temperaturas se observaron diferencias significativas en función de si la leche había sido o no tratada térmicamente. En general, los recuentos al final del almacenamiento fueron significativamente mayores en la leche LHT que en la leche cruda. Estos resultados eran esperables teniendo en cuenta el efecto que los microorganismos presentes de forma natural en la leche pueden ejercer sobre las 
bacterias patógenas. En varios trabajos, Nero et al. (2008; 2009) estudiaron el efecto que la población microbiana propia de la leche (principalmente $\mathrm{BAL}$ ) ejercía sobre patógenos tales como Listeria monocytogenes y Salmonella spp., apreciándose una inhibición total o parcial del crecimiento de estas bacterias. Además, el estudio realizado por Marek et al. (2004) en suero pasterizado y no pasterizado reveló que las BAL presentes en el suero no pasterizado ejercían un efecto inhibidor sobre $E$. coli 0157:H7.

Cuando se compara el efecto de las temperaturas de almacenamiento ensayadas en este trabajo; en general, a 6 으 se apreció un descenso significativo ( $p<$ 0,05 ) de los recuentos que oscilaba entre una y dos unidades logarítmicas (excepto en la muestra de leche pasterizada inoculada con la cepa no-O157:H7). Sin embargo, a

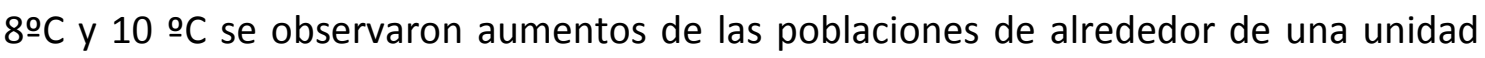
logarítmica (excepto para la muestra de leche cruda inoculada con la cepa no-0157:H7 e incubada a 8 ㄷ) . Durante la simulación de fallo en la cadena de frío se observó que, en leche LHT, los niveles de ambas cepas aumentaban significativamente mientras que en leche cruda disminuían.

Mamani et al. (2003) mantuvieron a 4으 y 20 으 muestras de diferentes tipos de leche UHT inoculadas con una mezcla de dos cepas de E. coli 0157:H7 y también con cepas no patógenas de esta especie. En las primeras $24 \mathrm{~h}$, las cepas patógenas crecieron en leche entera a 4 으 y en todas las demás a 20 ㄷ․ Wang et al. (1997) estudiaron el comportamiento de una mezcla de cinco cepas de E. coli O157:H7 en leche pasterizada y no pasterizada, observando que a 5ํㅡ no crecían y que la población descendía en 1,5-2 log ufc/ml tras 28 días de almacenamiento tanto en la leche tratada como en la cruda. A 8 으, los recuentos aumentaron entre 1 y 2 log ufc/ml en los cuatro primeros días y a 15 으 lo hicieron entre 3 y $5 \mathrm{log} u f c / m l$ a los tres días. A 22 으, el pH de la leche descendió rápidamente, no detectándose células viables de E. coli 0157:H7 a los 14 días. Palumbo et al. (1997) investigaron la evolución de cuatro cepas del serogrupo 0157 inoculadas en muestras de leche UHT, pasterizada y cruda almacenadas a distintas temperaturas. En leche pasterizada mantenida a 8 y $12^{\circ} \mathrm{C}$, en general, los recuentos aumentaron $y$, en el caso de la leche cruda, éstos se mantuvieron estables tanto a $8^{\circ} \mathrm{C}$ como a $12^{\circ} \mathrm{C}$. Los datos obtenidos en estos trabajos 
y los hallados por nosotros sugieren: a) que el almacenamiento de la leche a temperaturas $\leq 6$ oC permiten, al menos, la supervivencia de células viables de $E$. coli 0157:H7, b) que temperaturas de entre 8-20 ำ pueden permitir la multiplicación de estas cepas y, c) que la flora presente en la leche cruda suele inhibir el crecimiento de estas bacterias pero no garantizar su ausencia. Para cepas no-0157:H7 no hemos encontrado datos pero, en nuestro caso, la cepa objeto del estudio, creció significativamente en leche pasterizada mantenida a bajas temperaturas pero no lo hizo en leche cruda aunque siempre se detectaron células viables. Esto indica que la leche contaminada con cepas STEC y mantenida a las temperaturas exigidas por la normativa de la UE (Anónimo, 2004) puede suponer un riesgo si se destina a la fabricación de productos lácteos no tratados térmicamente. Finalmente, hay que señalar que aunque las cepas de E. coli 0157:H7 son bacterias mesófilas y, por tanto, teóricamente, incapaces de multiplicarse a temperaturas inferiores a $7 \stackrel{\circ}{ } \mathrm{C}$, existen algunas cepas que parecen poseer mecanismos genéticos especiales que permiten su supervivencia y multiplicación a bajas temperaturas (Vidovic et al., 2011).

Los datos publicados acerca del comportamiento de bacterias patógenas durante la elaboración y maduración del queso varían en función de la tecnología necesaria para su obtención (variedad o tipo de queso que se asocia a: $\mathrm{pH}, \mathrm{a}_{\mathrm{w}}$, contenido en $\mathrm{NaCl}$, etc.), influyendo, además, las características de la cepa ensayada y los métodos analíticos empleados (Peng et al., 2011). Es evidente, por tanto, que resulta difícil comparar los estudios del comportamiento de STEC ya que tanto los tipos de queso estudiados como la metodología varían aunque, habitualmente, se aprecia que los recuentos de STEC aumentan durante las primeras fases de la fabricación y disminuyen durante la maduración (Peng et al., 2011; Farrokh et al., 2013). Esto se ha observado durante la fabricación de quesos de vena azul y de otras variedades como Cheddar, Cammembert, Feta, etc. (Maher et al., 2001; Govaris et al., 2002; Schlesser et al., 2006; Montet et al., 2009; Miszczycha et al., 2013).

Al inicio del proceso de fabricación, la temperatura y la $a_{w}$ de la leche son adecuadas para el crecimiento de STEC. Cuando se coagula la leche, se produce un aumento de los recuentos de STEC debido, en parte, a que las células bacterianas quedan atrapadas en la cuajada (se estima un incremento de 10 veces) aunque 
también pueden haberse multiplicado (Farrokh et al., 2013). Durante la maduración, los niveles disminuyen significativamente aunque la tasa de inactivación varía, entre otras cosas, en función del tipo de queso y de la cepa. Así, Maher et al. (2001) observaron que una cepa de E. coli $0157: \mathrm{H7}$, inoculada en la leche destinada a la elaboración de un queso madurado superficialmente, pasaba durante las primeras 24

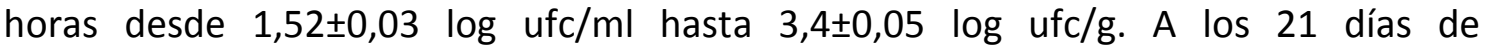
maduración, los niveles eran inferiores a $1 \mathrm{ufc} / \mathrm{g}$ en la superficie y $10 \mathrm{ufc} / \mathrm{g}$ en el interior del queso aunque utilizando una técnica de enriquecimiento, se detectaron células viables hasta después de 90 días. En otro trabajo realizado con quesos Feta y Telemes, Govaris et al. (2002), observaron que E. coli 0157:H7 (una mezcla de dos cepas) era indetectable después de 30-44 días de maduración, dependiendo de la variedad del queso y del cultivo iniciador utilizado (termofílico o mesofílico). En la exhaustiva revision de Farrokh et al. (2013), la mayoría de los estudios coinciden en el descenso de los niveles de esta bacteria aunque, en muchas ocasiones, se detectan células viables tras un almacenamiento prolongado. Una excepción es el trabajo de Ramsaran et al. (1998) que, en quesos Feta y Camembert, observaron niveles de $E$. coli 0157:H7 más altos en producto final (dos unidades logarítmicas) que al inicio del proceso. Estos últimos datos resultan, cuanto menos llamativos ya que se almacenaron a bajas temperaturas $(2 \pm 1$ 으 $\mathrm{C})$ durante 75 días.

En conjunto, nuestros resultados coinciden con los hallados en los trabajos citados. Por lo que respecta a los parámetros fisicoquímicos y a los niveles de BAL, siguieron el patrón esperable durante la elaboración y maduración de un queso tipo Zamorano. Los recuentos de la cepa de E. coli O157:H7 aumentaron una unidad logarítmica durante el proceso de elaboración del queso, disminuyendo posteriormente hasta llegar a unos recuentos finales de 6,25 ufc/g a los dos meses de maduración. Entre los estudios consultados, el de Govaris et al. (2002) es el que más se asemeja al nuestro tanto en la evolución de los parámetros físico químicos como en la evolución de las bacterias en las fases iniciales del proceso pero, al final del periodo de maduración, estos autores no detectan células viables a pesar del elevado inóculo inicial (5,6 log ufc/ml). 
Como ya se ha señalado previamente, a los dos meses de maduración, los recuentos finales de nuestra cepa de E. coli 0157:H7 inoculada en leche de oveja destinada a la fabricación de queso tipo Zamorano fueron de 6,25 ufc/g. No es fácil conocer la cantidad de queso tipo Zamorano consumida por un individuo pero en las grandes superficies se comercializan cuñas de $250 \mathrm{~g}$ divididas en 21 porciones (11,9 g); esto significaría 74,4 ufc de E. coli $0157: \mathrm{H} 7$ por porción y, es muy probable, que se consuman cantidades mayores. Por tanto, los niveles de esta bacteria se encontrarían en o superarían el rango de la dosis infectiva mínima y, esto significa que la leche destinada a la elaboración de quesos tipo Zamorano conteniendo niveles altos de $E$. coli 0157:H7 puede representar un riesgo para el consumidor. Esta conclusión habría que matizarla teniendo en cuenta que no es muy probable que la leche de oveja contenga ca. $3 \mathrm{log}$ ufc/ml de E. coli O157:H7; aunque este nivel de inóculo se eligió teniendo en cuenta el "peor escenario posible" en carne picada y en leche (ICMSF, 2002; Schlesser et al., 2006). Por otro lado, también hay que considerar que, en algunos estudios, se ha demostrado que $E$. coli 0157:H7 se encuentra en el queso en el interior de la matriz proteica individualmente pero también en pequeños grupos de unas 10 células y, por tanto, los recuentos bajos deberían ser interpretados con cautela ya que una sola colonia podría no corresponder a una única célula (Erickson \& Doyle, 2007; Baylis, 2009).

Finalmente, hay que señalar que en el Reglamento 209/2013 (Anónimo, 2013) en el que se establecen criterios microbiológicos para semillas germinadas (brotes), que son productos listos para el consumo, se incluyen cepas STEC de los serogrupos y serotipos 0157, 026, 0111, 0103, 0145 y 0104:H4. Para los brotes, deben analizarse cinco muestras de $25 \mathrm{~g}(\mathrm{n}=5)$ y ninguna de ellas $(\mathrm{c}=0)$ puede contener estas STEC $(m=0)$. La toma de muestras se realizará durante la comercialización y si no cumplen el criterio se deberán retirar del mercado.

En resumen: 1) las cepas de STEC presentan diferente resistencia a la acidez, 2) en leche de oveja, los niveles de las cepas STEC 0157 y no-0157 disminuyen, se mantienen o aumentan a las temperaturas de almacenamiento exigidas por la normativa vigente en la UE, siendo, como era de esperar, más favorable para su supervivencia y desarrollo la leche tratada térmicamente y 3) aunque los niveles de 
Capítulo IV. Discusión

STEC 0157 disminuyen durante la maduración, los quesos tipo Zamorano elaborados con leche cruda con una concentración inicial de E. coli 0157:H7 de ca. 3 log ufc/ml podrían suponer un riesgo para el consumidor dependiendo de la cantidad de queso consumido. 
Capítulo IV. Bibliografía

\section{BIBLOGRAFÍA}

1. Anónimo. 2013. Reglamento (UE) № 209/2013 de la Comisión de 11 de marzo de 2013 que modifica el Reglamento (CE) № 2073/2005 en lo que respecta a los criterios microbiológicos para los brotes y las normas de muestro para las canales de aves de corral y la carne fresca de aves de corral. D. O., L 68: 19-23.

2. Anónimo. 2006. Real Decreto 640/2006, de 26 de mayo, por el que se regulan determinadas condiciones de aplicación de las disposiciones comunitarias en materia de higiene, de la producción y comercialización de los productos alimenticios. BOE, № 126: 19999-20002.

3. Anónimo. 2004. Reglamento (CE) № 853/2004 del Parlamento Europeo y del Consejo de 29 de Abril de 2004, por el que se establecen normas específicas de higiene de los alimentos de origen animal. D. O., L 139: 55.

4. Anónimo. 1993. ORDEN de 6 de mayo de 1993 por la que se aprueba el Reglamento de la Denominación de Origen "Queso Zamorano" y su Consejo Regulador. BOE, № 120: 15311-15316.

5. Baylis, C. L. 2009. Raw milk and raw milk cheeses as vehicles for infection by Verocytotoxin-producing Escherichia coli. Int. J. Dairy Technol., 62: 293-307.

6. Bradley, R. L. 2006. Capítulo 33. Dairy Products. AOAC Official Method 935.43.

Chloride (Total) in Cheese. Volhard Method. In: Horwitz, W. and Latimer, G. W. (Eds.), Official Methods of Analysis. AOAC International, USA, pp. 71. 
Capítulo IV. Bibliografía

7. Caro, I. \& García-Armesto, M. R. 2007. Occurrence of Shiga toxin-producing Escherichia coli in a Spanish raw ewe's milk cheese. Int. J. Food Microbiol., 116: 410413.

8. Caro, I., Fernández-Barata, V. M., Alonso-Llamazares, A. and García-Armesto, M. R. 2006. Detection, occurrence, and characterization of Escherichia coli 0157:H7 from raw ewe's milk in Spain. J. Food Prot., 69: 920-924.

9. D'Amico, D. J., Groves, E. and Donnelly, C. W. 2008. Low incidence of foodborne pathogens of concern in raw milk utilized for farmstead cheese production. J. Food Prot., 71: 1580-1589.

10. Dontorou, C., Papadopoulou, C., Filioussis, G., Economou, V., Apostolou, I., Zakkas, G., Salamoura, A., Kansouzidou, A. and Levidiotou, S. 2003. Isolation of Escherichia coli 0157: H7 from foods in Greece. Int. J. Food Microbiol., 82: 273-279.

11. Elhadidy, M. \& Mohammed, M. A. 2012. Shiga toxin-producing Escherichia coli from raw milk cheese in Egypt: prevalence, molecular characterization and survival to stress conditions. Lett. Appl. Microbiol., 56: 120-127.

12. Elizaquível, P., Sánchez, G. and Aznar, R. 2011. Escherichia. In: Liu, D. (Ed.), Molecular detection of human bacterial pathogens. CRC Press, Boca Raton, FL, USA, pp. 869-879.

13. Erickson, M. C. \& Doyle, M. P. 2007. Food as a vehicle for transmission of Shiga toxinproducing Escherichia coli. J. Food Prot., 70: 2426-2449. 
14. Farrokh, C., Jordan, K., Auvray, F., Glass, K., Oppegaard, H., Raynaud, S., Thevenot,

D., Condron, R., De Reu, K. and Govaris, A. 2013. Review of Shiga-toxin-producing Escherichia coli (STEC) and their significance in dairy production. Int. J. Food Microbiol., 162 (2): 190-212.

15. Govaris, A., Papageorgiou, D. K. and Papatheodorou, K. 2002. Behavior of Escherichia coli 0157: H7 during the manufacture and ripening of feta and telemes cheeses. J. Food Prot., 65: 609-615.

16. Holko, I., Bisova, T., Holkova, Z. and Kmet, V. 2006. Virulence markers of Escherichia coli strains isolated from traditional cheeses made from unpasteurised sheep milk in Slovakia. Food Control, 17: 393-396.

17. ICMSF. 2002. Microorganisms in foods: 7. Microbiological testing in food safety management. Kluwer Academic / Plenum publishers. New York.

18. Jay, J. M., Loessner, M. J. and Golden, D. A. 2005. Chapter 27, Foodborne gastroenteritis caused by Escherichia coli. In: Jay, J. M., Loessner, M. J. and Golden, D. A. (Eds.), Modern food microbiology. Springer Verlag.

19. Kaper, J. B., Nataro, J. P. and Mobley, H. L. 2004. Pathogenic Escherichia coli. Nature Reviews Microbiology, 2: 123-140.

20. Maher, M. M., Jordan, K. N., Upton, M. E. and Coffey, A. 2001. Growth and survival of E. coli $0157: \mathrm{H} 7$ during the manufacture and ripening of a smear-ripened cheese produced from raw milk. J. Appl. Microbiol., 90: 201-207. 
21. Mamani, Y., Quinto, E. J., Simal-Gandara, J. and Mora, M. T. 2003. Growth and survival of Escherichia coli 0157: $\mathrm{H} 7$ in different types of milk stored at 4 으 $\mathrm{C}$ or 20 ㅇ. J. Food Sci., 68: 2558-2563.

22. Marek, P., Nair, M. K. M. and Venkitanarayanan, K. 2004. Survival and growth characteristics of Escherichia coli 0157: $\mathrm{H} 7$ in pasteurized and unpasteurized Cheddar cheese whey. Int. J. Food Microbiol., 94: 1-7.

23. Martin, A. \& Beutin, L. 2011. Characteristics of Shiga toxin-producing Escherichia coli from meat and milk products of different origins and association with food producing animals as main contamination sources. Int. J. Food Microbiol., 146: 99-104.

24. Miszczycha, S. D., Perrin, F., Ganet, S., Jamet, E., Tenenhaus-Aziza, F., Montel, M. C. and Thevenot-Sergentet, D. 2013. Behavior of different Shiga toxin-producing Escherichia coli serotypes in various experimentally contaminated raw-milk cheeses. Appl. Environ. Microbiol., 79: 150-158.

25. Montet, M. P., Jamet, E., Ganet, S., Dizin, M., Miszczycha, S., Dunière, L., Thevenot, D. and Vernozy-Rozand, C. 2009. Growth and survival of acid-resistant and non-acidresistant Shiga-toxin-producing Escherichia coli strains during the manufacture and ripening of camembert cheese. Int. J. Microbiol., 2009.

26. Mora, A., León, S. L., Blanco, M., Blanco, J. E., López, C., Dahbi, G., Echeita, A., González, E. A. and Blanco, J. 2007. Phage types, virulence genes and PFGE profiles of Shiga toxin-producing Escherichia coli 0157: H7 isolated from raw beef, soft cheese and vegetables in Lima (Peru). Int. J. Food Microbiol., 114: 204-210. 
27. Muehlherr, J. E., Zweifel, C., Corti, S., Blanco, J. E. and Stephan, R. 2003.

Microbiological quality of raw goat's and ewe's bulk-tank milk in Switzerland. J. Dairy Sci., 86: 3849-3856.

28. Nero, L. A., De Mattos, M. R., de Aguiar Ferreira Barros, M., Ortolani, M. B. T., Beloti, V. and de Melo Franco, B. D. G. 2008. Listeria monocytogenes and Salmonella spp. in raw milk produced in Brazil: occurrence and interference of indigenous microbiota in their isolation and development. Zoonoses and Public Health, 55: 299305.

29. Nero, L., Mattos, M., Beloti, V., Barros, M., Ortolani, M. and Franco, B. 2009. Autochthonous microbiota of raw milk with antagonistic activity against Listeria monocytogenes and Salmonella enteritidis. J. Food Saf., 29: 261-270.

30. Palumbo, S. A., Pickard, A. and Call, J. E. 1997. Population changes and verotoxin production of enterohemorrhagic Escherichia coli strains inoculated in milk and ground beef held at low temperatures. J. Food Prot., 60: 746-750.

31. Peng, S., Tasara, T., Hummerjohann, J. and Stephan, R. 2011. An overview of molecular stress response mechanisms in Escherichia coli contributing to survival of Shiga toxinproducing Escherichia coli during raw milk cheese production. J. Food Prot., 74: 849-864.

32. Ramsaran, H., Chen, J., Brunke, B., Hill, A. and Griffiths, M. W. 1998. Survivial of bioluminescent Listeria monocytogenes and Escherichia coli 0157: $\mathrm{H} 7$ in soft cheeses. J. Dairy Sci., 81: 1810-1817. 
33. Rey, J., Sánchez, S., Blanco, J. E., Hermoso de Mendoza, J., Hermoso de Mendoza, M., García, A., Gil, C., Tejero, N., Rubio, R. and Alonso, J. M. 2006. Prevalence, serotypes and virulence genes of Shiga toxin-producing Escherichia coli isolated from ovine and caprine milk and other dairy products in Spain. Int. J. Food Microbiol., 107: 212-217.

34. Schlesser, J. E., Gerdes, R., Ravishankar, S., Madsen, K., Mowbray, J. and Teo, A. Y. L. 2006. Survival of a five-strain cocktail of Escherichia coli 0157: H7 during the 60-day aging period of cheddar cheese made from unpasteurized milk. J. Food Prot., 69: 990998.

35. Solomakos, N., Govaris, A., Angelidis, A. S., Pournaras, S., Burriel, A. R., Kritas, S. K. and Papageorgiou, D. K. 2009. Occurrence, virulence genes and antibiotic resistance of Escherichia coli $\mathrm{O} 157$ isolated from raw bovine, caprine and ovine milk in Greece. Food Microbiol., 26: 865-871.

36. Vernozy-Rozand, C., Montet, M. P., Berardin, M., Bavai, C. and Beutin, L. 2005. Isolation and characterization of Shiga toxin-producing Escherichia coli strains from raw milk cheeses in France. Lett. Appl. Microbiol., 41: 235-241.

37. Vidovic, S., Mangalappalli-Illathu, A. K. and Korber, D. R. 2011. Prolonged cold stress response of Escherichia coli 0157 and the role of rpoS. Int. J. Food Microbiol., 146: 163-169.

38. Wang, G., Zhao, T. and Doyle, M. P. 1997. Survival and growth of Escherichia coli O157: H7 in unpasteurized and pasteurized milk. J. Food Prot., 60: 610-613. 
Capítulo IV. Bibliografía

39. Welch, R. A. 2006. The Genus Escherichia. In: Dworkin, M., Falkow, S., Rosenberg, E., Schleifer, K. and Stackebrandt, E. (Eds.), The Prokaryotes: A handbook on the biology of bacteria: Vol. 6: Proteobacteria: Gamma subclass. Springer, Singapore, pp. 60-71. 
CAPÍTULO V: Evaluación de dos películas activas para el control de cepas de Escherichia coli

0157: $\mathrm{H7}$ en queso madurado de oveja (Zamorano) 



\section{INTRODUCCIÓN}

Basándose en sus factores de virulencia, las cepas de $E$. coli patógenas para el hombre se clasifican en seis grupos o "patotipos". Uno de ellos es el denominado enterohemorrágico (EHEC) que, a su vez, pertenece a un grupo de cepas productoras de toxinas Shiga (STEC) también denominadas cepas de E. coli productoras de verotoxinas (VTEC) (Nataro \& Kaper, 1998). A varios serogrupos y serotipos de STEC se les reconoce como enterohemorrágicos y pueden causar graves enfermedades humanas de transmisión alimentaria, destacando entre ellos E. coli 0157:H7. Estas bacterias se caracterizan por su baja dosis infectiva (entre 10 y 100 células) y por su capacidad para producir diarrea y colitis hemorrágica. Estos procesos pueden progresar a cuadros más severos como el síndrome urémico hemolítico (SUH) que puede llegar a ser fatal, especialmente en niños y ancianos. Así, el SUH es la principal causa de fallo renal en los más jóvenes y puede ocasionar una elevada morbilidad e incluso la muerte en personas mayores (Meng et al., 2013).

El principal reservorio de este patógeno son los rumiantes domésticos y silvestres (Ferens \& Hovde, 2011) y los alimentos involucrados más frecuentemente son las hamburguesas insuficientemente cocinadas y otros productos cárnicos así como agua no higienizada, frutas y verduras y quesos elaborados con leche cruda (Espié et al., 2006; Farrokh et al., 2013). La incidencia de E. coli 0157:H7 y otros EHEC en quesos elaborados con leche de oveja y en leche cruda de oveja destinada a la fabricación de queso ha sido investigada en varios países (Rey et al., 2006; Caro \& García-Armesto, 2007; Caro et al., 2011; Farrokh et al., 2013).

La explotación del ganado ovino es una actividad muy importante en España (ca. $22 \%$ de la UE) y se concentra principalmente en algunas Comunidades Autónomas como Castilla y León que, según datos del Ministerio de Agricultura, Alimentación y Medio Ambiente (http://www.magrama.gob.es), es la primera Comunidad productora de leche de oveja (70\% de la producción nacional). La mayor parte de la leche producida se dedica (sin previo tratamiento térmico) a la elaboración de queso, siendo uno de los más consumidos la variedad de queso Zamorano. 
Los principios del envasado activo han sido revisados en la "Introducción General". El envasado activo ha sido definido como un envase que proporciona ventajas añadidas a las del envasado a vacío y en atmósfera modificada (Rooney, 2005) y de acuerdo con la normativa (Reglamento (CE) no 450/2009) (Anónimo, 2009), “los materiales y objetos activos son los destinados a prolongar la vida útil o a mantener o mejorar el estado del alimento envasado. Están diseñados para incorporar intencionadamente componentes que liberarán sustancias en el alimento envasado o en su entorno o absorberán sustancias del alimento o de su entorno".

El envasado antimicrobiano es una forma de envasado activo. La utilización de envases activos conteniendo compuestos antimicrobianos beneficia tanto al consumidor como a la industria alimentaria ya que puede incrementar la vida útil de los alimentos y/o mantener la inocuidad de éstos bien inactivando los microorganismos diana o reduciendo su tasa de crecimiento. Se han propuesto numerosos compuestos para ser incorporados al material de envasado (Suppakul et al., 2003; Cha \& Chinnan, 2004); algunos de ellos son ciertos productos químicos, "agentes naturales" y probióticos. Entre los propuestos y ensayados destacan el aceite esencial de orégano -Origanum vulgare L- (OR) y el Etil Lauroil Arginato (LAE) (Han, 2005).

Un número reducido de estudios presentan datos acerca del efecto de películas conteniendo OR y LAE frente a algunos serovares de Salmonella, Listeria monocytogenes y cepas no patógenas de $E$. coli presentes en envases de ensalada (Muriel-Galet et al., 2012b), preparados para lactantes (Muriel-Galet et al., 2012a) y lonchas de jamón cocido (Theinsathid et al., 2012). Sin embargo, no existe información relativa al efecto de películas recubiertas con OR y LAE en el comportamiento de cepas pertenecientes al serotipo patógeno E. coli 0157:H7. 
Capítulo V. Introducción

\section{OBJETIVO}

El trabajo recogido en este capítulo se diseñó para evaluar la actividad frente a E. coli $0157: \mathrm{H} 7$ de dos películas distintas recubiertas con diferentes concentraciones de OR y LAE. Los ensayos se realizaron mediante estudios in vitro y también por contacto directo con muestras inoculadas de queso Zamorano. Asimismo, se evaluó el efecto de estos envases en la calidad organoléptica del queso. 


\section{MATERIAL Y MÉTODOS}

\section{CEPAS}

Se emplearon dos cepas de E. coli O157:H7. Una de ellas fue la cepa CECT (Colección Española de Cultivos Tipo) 5947 y, la otra, la cepa STEC M364VO aislada por nosotros de leche de tanque en una explotación de ganado ovino. La segunda cepa poseía los genes stx2 y eae.

Ambas cepas se mantuvieron a -18 으 en Nutrient Broth (NB, Scharlab, Barcelona, España) con $40 \%$ de glicerol. Para los ensayos, las cepas se incubaron previamente en Tryptone Soya Broth (TSB, Scharlab) durante 18 horas a 37 ㅇ․

\section{COMPUESTOS ANTIMICROBIANOS}

El aceite esencial de orégano había sido obtenido de Origanum vulgare L (Chemical Abstracts Service (CAS) número de registro 8007-11-2) y suministrado por Argolide Química SL (Barcelona, España). EI LAE (CAS número de registro 60372-77-2) fue suministrado por Lamirsa (Barcelona, España).

\section{PRUEBAS DE SUSCEPTIBILIDAD ANTIMICROBIANA}

\subsection{Pruebas de dilución en caldo}

Tanto para OR como para LAE, la concentración mínima inhibidora (CMI) y la concentración mínima bactericida $(\mathrm{CMB})$ se determinaron empleando una técnica de dilución en caldo (Becerril et al., 2007).

OR: Utilizando dimetil sulfóxido (DMSO) (Sigma-Aldrich Química, S.A., Madrid, España), se realizaron diluciones de factor dos en el rango 2,5-160 mg/ml (Sacchetti et

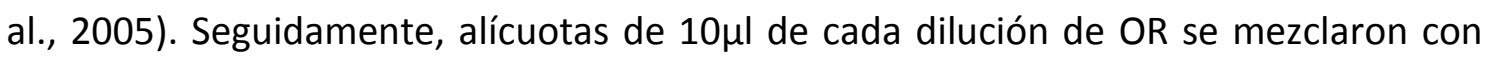
$890 \mu \mathrm{l}$ de TSB conteniendo $0,6 \%$ de extracto de levadura (TSBYE, Scharlab) y se inocularon con $100 \mu \mathrm{l}$ de una suspensión bacteriana en TSBYE (Scharlab) conteniendo $10^{6} \mathrm{ufc} / \mathrm{ml}$. Las concentraciones finales de OR en la prueba oscilaban entre 0,025 y 1,6 $\mathrm{mg} / \mathrm{ml}$. Como control, para evaluar si el DMSO (Sigma-Aldrich Química) inhibía a las 
dos cepas objeto del ensayo, se utilizaron $10 \mu \mathrm{l}$ de este compuesto en lugar de las diluciones de OR.

En todos los casos, los cultivos se incubaron con agitación durante 24 horas a 37 ํ. E. El crecimiento bacteriano se determinó midiendo la densidad óptica a $625 \mathrm{~nm}$. Además, se tomaron muestras de $100 \mu$ que se diluyeron (factor 10), se sembraron en placas de Tryptone Soya Agar (TSA, Scharlab) y se incubaron a $37 \stackrel{\circ}{C}$ durante 24 horas. Con cada cepa, el ensayo se realizó tres veces.

LAE: Utilizando agua destilada estéril, se realizaron diluciones de factor dos en el rango $1,25-160 \mathrm{mg} / \mathrm{ml}$ y el ensayo se realizó como para el OR, estando las concentraciones finales entre 0,0125 y $1,6 \mathrm{mg} / \mathrm{ml}$. Se procedió del mismo modo que en el ensayo con OR, aunque en esta prueba los cultivos se incubaron sin agitación. Como en el caso anterior, con cada cepa, el ensayo se realizó tres veces.

La CMI se definió como la menor concentración del compuesto antimicrobiano en la que no se detectó crecimiento de las bacterias. La CMB se definió como la menor concentración del compuesto antimicrobiano en la que las cepas ensayadas no crecían en TSBYE (Scharlab) y tampoco en las placas de TSA (Scharlab).

\subsection{Actividad antimicrobiana de láminas tratadas con OR y LAE}

Para estos ensayos se utilizaron dos tipos de láminas: Polipropileno (PP) y Polietilentereftalato (PET). El PET presentaba $23 \mu \mathrm{m}$ de espesor con una densidad de $18,73 \pm 0,02 \mathrm{~g} / \mathrm{m}^{2}$, mientras que el PP tenía $40 \mu \mathrm{m}$ de espesor. En ambos casos, se recubrieron con formulaciones conteniendo los agentes antimicrobianos mediante un proceso protegido por la patente europea EP1657181 (Nerín \& Garcés, 2006). Las películas activas contenían la sustancia activa expresada como un porcentaje de peso de agente activo/peso de la capa activa húmeda. La cantidad de barniz añadida a las láminas fue de $4 \mathrm{~g} / \mathrm{m}^{2}$ en todos los casos.

En el caso del OR se estudió su acción en fase de vapor y por contacto directo mientras que en el caso del LAE únicamente se comprobó su acción por contacto directo ya que este compuesto no es activo en fase de vapor. 


\subsubsection{Actividad antimicrobiana en fase vapor}

Se investigó la acción antimicrobiana del OR incorporado en el material de envasado frente a las dos cepas de E. coli utilizando los dos tipos de láminas.

Las películas con actividad antimicrobiana, que fueron producidas por Artibal (Sabiñánigo, Huesca, España), tenían incorporadas diferentes concentraciones de OR $(4,6$ y $8 \%)$. Las formulaciones de OR se prepararon utilizando como solvente un barniz (ATOX) también desarrollado por Artibal.

Para realizar el ensayo, se sembraron, en superficie, placas de TSA (Scharlab) con $100 \mu \mathrm{l}$ de TSBYE (Scharlab) conteniendo $10^{6} \mathrm{ufc} / \mathrm{ml}$ de cada cepa. Las tapas de las placas se sustituyeron por las películas tratadas sujetándolas a la base con una brida (López et al., 2007b). Los controles se prepararon de forma idéntica pero las películas estaban recubiertas con el barniz sin incorporar OR. Transcurrido el período de incubación (24 h a $37 \stackrel{\circ}{\circ}$ ), se comparó el crecimiento de las cepas en las placas cubiertas con películas activas con el de las placas control, estableciéndose las categorías siguientes: -, sin inhibición; +, inhibición parcial y ++, inhibición total. Cada ensayo se realizó por triplicado.

\subsubsection{Actividad antimicrobiana por contacto directo}

OR: Se estudió la acción antibacteriana del OR por contacto directo frente a las dos cepas de E. coli utilizando los dos tipos de lámina. El protocolo seguido está recogido en la norma "Japanese Industrial Standard method JIS Z 2801:2000" (Anónimo, 2000).

De forma resumida, trocitos cuadrados $(50 \times 50 \mathrm{~mm})$ de PP y PET tratados con 4, 6 y $8 \%$ OR se colocaron, con la superficie activa hacia arriba, en placas de Petri vacías. Sobre estos cuadrados (tres por cada concentración de OR) se depositaban $400 \mu \mathrm{l}$ de TSBYE (Scharlab) conteniendo $10^{5} \mathrm{ufc} / \mathrm{ml}$ de la cepa a ensayar, cubriéndose finalmente con otros tantos cuadrados $(40 \times 40 \mathrm{~mm})$ de la misma película sin tratar (recubierta sólo con ATOX). Este mismo proceso se llevó a cabo con tres láminas de PP y tres de PET recubiertas únicamente con ATOX, sin OR. Todas las láminas conteniendo OR, después de incubarse a 37 ㅇ C durante $24 \mathrm{~h}$, se introdujeron en una bolsa de "stomacher", y se 
"lavaron" con $10 \mathrm{ml}$ de agua de peptona. Se realizaron diluciones de esta suspensión, sembrando $100 \mu$ l en la superficie de TSA (Scharlab). Tras la incubación de las placas $(24 \mathrm{~h}$ a $37 \stackrel{\circ}{\mathrm{O}}$ ) se contaron las colonias. El mismo protocolo de lavado, diluciones, siembra y recuento se llevó a cabo con las películas sin OR inmediatamente después de inocular y tras $24 \mathrm{~h}$ de incubación.

La actividad antimicrobiana se expresó como valor R. Este valor se calculó utilizando la fórmula $R=\log (B / C)$, siendo $B$ la media de los recuentos de las películas sin tratar (momento 0) y C la media de los recuentos de las películas tratadas (tras $24 \mathrm{~h}$ de incubación).

LAE: Se utilizaron láminas de PP y PET tratadas con tres concentraciones de LAE (4, 6 y 8\%). Las formulaciones se prepararon utilizando como solvente un barniz (ACRIL), también diseñado por Artibal.

Para determinar la actividad antimicrobiana del LAE por contacto directo, no se pudo utilizar el método recogido en la norma japonesa ("Japanese Industrial Standard method JIS Z 2801:2000”) ya que la suspensiones bacterianas no se fijaban bien a la lámina y los resultados, por tanto, no eran fiables.

Se empleó una técnica de difusión en agar en la forma descrita por Iseppi et al. (2008). Trocitos cuadrados $(40 \times 40 \mathrm{~mm})$ de PP y PET tratados con LAE se colocaron en la superficie de placas de TSA (Scharlab) que previamente habían sido inoculadas con un cultivo de las cepas crecidas durante $18 \mathrm{~h}$ a $37 \stackrel{\circ}{\circ}$ en TSBYE (Scharlab) (ca. $10^{8}$ $\mathrm{ufc} / \mathrm{ml}$ ). Las placas se incubaron a $37 \stackrel{\circ}{ } \mathrm{C}$ durante 24 horas. La actividad antibacteriana se cuantificó midiendo el halo de inhibición alrededor de la lámina. Como controles se utilizaron láminas de PP y PET recubiertas únicamente con el barniz ACRIL.

\section{ACTIVIDAD ANTIMICROBIANA EN QUESO ZAMORANO}

Para comprobar el efecto de los envases activos (PP y PET recubiertos de OR y LAE) sobre las cepas de E. coli 0157:H7 inoculadas en un alimento, se utilizó queso Zamorano. Esta es una variedad de queso madurado elaborado con leche cruda de oveja de las razas Churra y/o Castellana. Hay que recordar que la cepa STEC M364VO 
había sido aislada de una explotación cuya producción se destinaba a la fabricación de queso de esta variedad.

Se adquirieron cuñas ya loncheadas de queso Zamorano preparadas para un consumo doméstico estimado de una semana. La superficie de las lonchas se inoculó sumergiéndolas en un cultivo de las cepas en TSBYE (Scharlab) conteniendo $10^{6} \mathrm{ufc} / \mathrm{ml}$, siendo la concentración final en las lonchas de ca. $10^{4} \mathrm{ufc} / \mathrm{g}$.

Lonchas sin contaminar (controles) y las lonchas contaminadas se colocaron en contacto directo con láminas de PP y PET recubiertas sólo de los barnices (ATOX y ACRIL) y de tres concentraciones $(4,6$ y $8 \%)$ de cada compuesto antimicrobiano. Las lonchas así preparadas se envasaron en bolsas de PP normal y se almacenaron a 3 oC para simular condiciones domésticas de almacenamiento.

Se hicieron recuentos de E. coli 0157:H7 inmediatamente después de la inoculación y tras un día y una semana de almacenamiento utilizando placas de

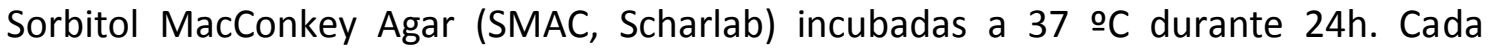
experimento se repitió seis veces.

\section{ANÁLISIS ESTADÍSTICO DE LOS DATOS OBTENIDOS EN QUESO ZAMORANO}

Los recuentos de E. coli 0157:H7 obtenidos en el análisis microbiológico se transformaron y expresaron como $\log _{10}$ ufc/g. Para cada parámetro, se calcularon las medias y desviaciones estándar. Se utilizó el análisis de regresión lineal para estudiar la relación entre los diferentes parámetros. Se analizó la posible influencia de la cepa, la lámina, los compuestos antimicrobianos y sus concentraciones y el tiempo de almacenamiento empleando un análisis de la varianza multifactorial (ANOVA).

Finalmente se llevó a cabo un análisis "post-hoc" mediante la prueba de Fisher de la mínima diferencia significativa (Fisher's Least Significant Difference -LSD- test).

El análisis de todos los datos se llevó a cabo empleando el programa "Statistica for Windows" versión 7.0 (Statsoft Inc., Tulsa, OK, USA) (www.statsoft.com). 


\section{ANÁLISIS SENSORIAL}

Se realizó el análisis sensorial de lonchas sin envasar y de lonchas (no contaminadas) del mismo queso Zamorano envasadas en contacto directo con las láminas (PP y PET) recubiertas con las diferentes concentraciones de OR y LAE. LoS análisis se realizaron en cuatro días distintos, siendo su objetivo evaluar si los envases activos modificaban las características organolépticas del queso.

Se reclutó un panel de diez jueces cualificados a los que se pidió que ordenaran las muestras en orden decreciente de aceptabilidad general. Datos acerca del tipo de lámina, el antimicrobiano y su concentración y el tiempo de almacenamiento se presentan en las Tablas V.1. y V.2. Los datos se analizaron e interpretaron utilizando el test de Friedman de acuerdo con la Norma ISO 8587:2010 (Anónimo, 2010).

Tabla.V.1. Información relativa al análisis sensorial de láminas de queso Zamorano envasadas en películas recubiertas con diferentes concentraciones de OR.

\begin{tabular}{|c|c|c|c|c|}
\hline Día de análisis & № de muestra & Lámina & $\% O R^{a}$ & $\begin{array}{c}\text { Tiempo de } \\
\text { almacenamiento }\end{array}$ \\
\hline \multirow{7}{*}{ Día 1} & 425 & No lámina & 0 & No \\
\hline & 504 & \multirow{6}{*}{$\mathrm{PP}^{\mathrm{b}}$} & $4 \%$ & \multirow{3}{*}{24 horas } \\
\hline & 216 & & $6 \%$ & \\
\hline & 475 & & $8 \%$ & \\
\hline & 812 & & $4 \%$ & \multirow{3}{*}{1 semana } \\
\hline & 483 & & $6 \%$ & \\
\hline & 514 & & $8 \%$ & \\
\hline \multirow{7}{*}{ Día 2} & 569 & No plástico & 0 & No \\
\hline & 883 & \multirow{6}{*}{$\mathrm{PET}^{\mathrm{c}}$} & $4 \%$ & \multirow{3}{*}{24 horas } \\
\hline & 153 & & $6 \%$ & \\
\hline & 358 & & $8 \%$ & \\
\hline & 149 & & $4 \%$ & \multirow{3}{*}{1 semana } \\
\hline & 899 & & $6 \%$ & \\
\hline & 987 & & $8 \%$ & \\
\hline
\end{tabular}

${ }^{a} \mathrm{OR}$, aceite esencial de orégano obtenido de Origanum vulgare

${ }^{\mathrm{b}} \mathrm{PP}$, Polipropileno

'PET, Polietilentereftalato 
Tabla V.2. Información relativa al análisis sensorial de láminas de queso Zamorano envasadas en películas recubiertas con diferentes concentraciones de LAE.

\begin{tabular}{|c|c|c|c|c|}
\hline Día de análisis & № de muestra & Lámina & $\% \operatorname{LAE}^{\mathrm{a}}$ & $\begin{array}{c}\text { Tiempo de } \\
\text { almacenamiento }\end{array}$ \\
\hline \multirow{7}{*}{ Día 3} & 352 & No lámina & 0 & No \\
\hline & 557 & \multirow{6}{*}{$\mathrm{PP}^{\mathrm{b}}$} & $4 \%$ & \multirow{3}{*}{24 horas } \\
\hline & 877 & & $6 \%$ & \\
\hline & 756 & & $8 \%$ & \\
\hline & 747 & & $4 \%$ & \multirow{3}{*}{1 semana } \\
\hline & 939 & & $6 \%$ & \\
\hline & 285 & & $8 \%$ & \\
\hline \multirow{7}{*}{ Día 4} & 638 & No plástico & 0 & No \\
\hline & 260 & \multirow{6}{*}{$\mathrm{PET}^{\mathrm{C}}$} & $4 \%$ & \multirow{3}{*}{24 horas } \\
\hline & 548 & & $6 \%$ & \\
\hline & 820 & & $8 \%$ & \\
\hline & 727 & & $4 \%$ & \multirow{3}{*}{1 semana } \\
\hline & 231 & & $6 \%$ & \\
\hline & 518 & & $8 \%$ & \\
\hline
\end{tabular}

aAE, Etil Lauroil Arginato

${ }^{\mathrm{b}} \mathrm{PP}$, Polipropileno

${ }^{\mathrm{C}} \mathrm{PET}$, Polietilentereftalato 


\section{RESULTADOS Y DISCUSIÓN}

\section{DETERMINACIÓN DE LOS VALORES CMI Y CMB FRENTE A E. coli 0157:H7}

Los valores CMI y CMB para ambas cepas de E. coli O157:H7 se presentan en la Tabla V.3.

Tabla V.3. $\mathrm{CMI}^{\mathrm{a}}$ y $\mathrm{CMB}^{\mathrm{b}}$ para dos cepas de $E$. coli $\mathrm{O} 157: \mathrm{H} 7$ en los ensayos de dilución en caldo.

\begin{tabular}{llll}
\hline ANTIMICROBIANO & CEPA & CMI (mg/l) & CMB (mg/l) \\
\hline \multirow{2}{*}{ OR $^{\mathrm{c}}$} & M364VO & 400 & 400 \\
& CECT 5947 & 200 & 200 \\
\hline \multirow{2}{*}{ LAE $^{\mathrm{f}}$} & M364VO & 25 & 25 \\
& CECT5947 & 25 & 25 \\
\hline
\end{tabular}

${ }^{a}$ Concentración mínima inhibidora

${ }^{b}$ Concentración mínima bactericida

${ }^{c} \mathrm{OR}$, aceite esencial de orégano obtenido de Origanum vulgare

${ }^{\mathrm{d}}$ Cepa de origen ovino

e CECT, Colección Española de Cultivos Tipo

fLAE, Etil Lauroil Arginato

Como puede observarse, para cada compuesto, los valores $\mathrm{CMB}$ fueron idénticos a sus respectivas CMIs. EI LAE mostró mayor actividad anti-E.coli que el OR y este último fue el doble de eficaz frente a la cepa patrón que frente a la cepa obtenida de leche de oveja. En un estudio llevado a cabo por Becerril et al. (2007) se determinaron los valores CMI y CMB del OR sobre una cepa patrón no patógena de E. coli (ATCC 25922). En este caso, los valores de CMI y CMB también resultaron idénticos, siendo de $190 \mathrm{mg} / \mathrm{l}$, valor muy similar al obtenido en este trabajo para la cepa de colección (CECT 5947), mientras que la cepa de origen ovino (M364VO) resultó mucho más resistente. Otros investigadores obtuvieron resultados de CMI para el OR cercanos a los observados por nosotros para la cepa de origen ovino (Gutiérrez et al., 2008; Turgis et al., 2012). En el caso del LAE, se hallaron resultados idénticos en un estudio desarrollado por Becerril et al. (2013), y comparables a los publicados en otros trabajos (Muriel-Galet et al., 2012a; Higueras et al., 2013).

La elevada actividad antimicrobiana del LAE frente a las bacterias Gram-negativas se ha atribuido a alteraciones que afectan tanto a la membrana citoplasmática como a la membrana externa sin que tenga lugar la lisis celular (Rodríguez et al., 2004). Por lo que 
respecta a los aceites esenciales de origen vegetal, se ha demostrado que el obtenido de Origanum vulgare presenta la mayor actividad bacteriostática y bactericida tanto para cepas verotoxigénicas como no verotoxigénicas de E. coli (Marino et al., 2001; Burt \& Reinders, 2003).

\section{ACTIVIDAD ANTIMICROBIANA EN FASE VAPOR}

La Tabla V.4 presenta el efecto inhibidor de la atmósfera generada por diferentes concentraciones de OR incorporadas en el material de envasado (PP y PET). La Figura V.1 ilustra el crecimiento de la cepa CECT 5947 en las placas cubiertas con las películas activas conteniendo tres concentraciones de OR.

Tabla V.4. Actividad antimicrobiana de la atmósfera generada por diferentes concentraciones de $\mathrm{OR}^{\mathrm{a}}$ incorporadas a dos películas de envasado frente a dos cepas de $E$. coli 0157:H7.

\begin{tabular}{llll}
\hline PELÍCULA & CONCENTRACIÓN & M364VO $^{\mathbf{b}}$ & CECT $^{\mathrm{c}} \mathbf{5 9 4 7}$ \\
\hline \multirow{3}{*}{ PP $^{\mathrm{f}}$} & ATOX $^{\mathrm{d}}(0 \%)$ & - & $-{ }^{\mathrm{e}}$ \\
& $4 \%$ & - & - \\
& $6 \%$ & + & + \\
& $8 \%$ & ++ & ++ \\
PET $^{\mathrm{g}}$ & ATOX (0\%) & - & - \\
& $4 \%$ & - & - \\
& $6 \%$ & + & + \\
& $8 \%$ & + & ++ \\
\hline
\end{tabular}

${ }^{a} \mathrm{OR}$, aceite esencial de orégano obtenido de Origanum vulgare

${ }^{\mathrm{b}}$ Cepa de origen ovino

${ }^{c} \mathrm{CECT}$, Colección Española de Cultivos Tipo

${ }^{\mathrm{d}}$ Barniz sin OR

e-, sin inhibición; +, inhibición parcial y ++, inhibición total

$\mathrm{f}_{\mathrm{PP}}$, polipropileno

${ }^{\text {g }}$ PET, Polietilentereftalato

$\mathrm{Ni}$ el barniz ATOX ni el aceite esencial de orégano a concentraciones del $4 \%$ inhibieron el crecimiento de las cepas de E. coli 0157:H7 pero si que lo hicieron concentraciones del 6\% (inhibición parcial) y del 8\% (inhibición total o parcial dependiendo de la película) (Tabla V. 4). Varios trabajos (Becerril et al., 2007; López et al., 2007a; Rodríguez et al., 2008; Gutiérrez et al., 2010) han demostrado que, en los ensayos de actividad antimicrobiana en fase de vapor, la actividad de los envases conteniendo aceites esenciales (EOs) es producida por los compuestos volátiles presentes en el espacio de 
cabeza de la placa de Petri y por los compuestos activos que pasan al medio de cultivo. Para el OR, estos compuestos han sido identificados como agentes fenólicos tales como carvacrol y timol aunque otros compuestos minoritarios parece que ejercen un papel significativo (Burt, 2004; Gutiérrez et al., 2010).
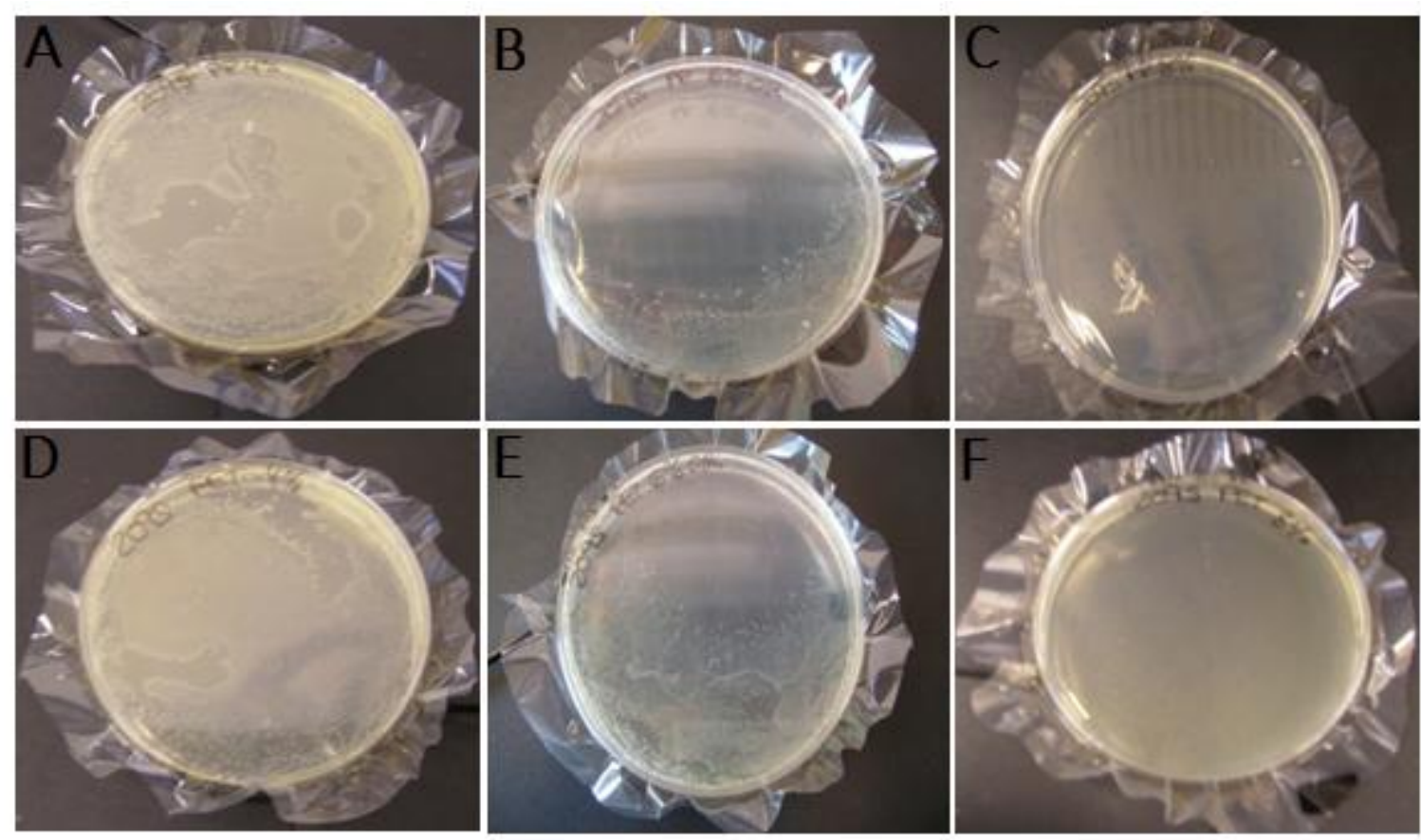

Figura V.1. Crecimiento de la cepa CECT 5947 sometida a la acción del OR en fase de vapor con los dos tipos de láminas recubiertas con OR al 4, 6 y $8 \%$. Láminas de PP A, B y C: -, +, ++. Láminas de PET D, E y F: -, +, ++.

Los estudios, por métodos en fase de vapor, sobre los aceites esenciales incorporados en envases, ponen de manifiesto que la eficacia está relacionada con la concentración del compuesto activo, el material de envasado y el microorganismo diana (López et al., 2007a; Rodríguez et al., 2008; Gutiérrez et al., 2010). En este trabajo, al aumentar la concentración de OR en el envase activo, aumentaba la actividad antimicrobiana, siendo $6 \%$ OR, la mínima concentración que inhibía a ambas cepas. Al 8\% OR, se observaron diferencias entre PP y PET. Así, la película 8\% OR PP inhibía completamente a las dos cepas ensayadas mientras que la película 8\% OR PET sólo inhibía completamente a la cepa de colección. Investigando in vitro el comportamiento de diferentes películas, Gutiérrez et al. (2010) concluyeron que, además de la concentración del compuesto activo, el polímero utilizado era un punto crítico en el diseño de los envases 
activos porque la cinética de liberación de éstos desempeñaba un papel decisivo para alcanzar, en el medio, la concentración del compuesto activo que era necesaria para actuar sobre el microorganismo diana durante su fase de latencia y así inhibir su crecimiento. De hecho, una vez que el compuesto activo se incorpora al polímero pasa a formar parte de éste, ya que no es posible separarlo. Dependiendo de la polaridad del sustrato la liberación del compuesto activo será diferente. Es bien sabido que la capacidad de absorción y la difusión de los productos químicos en las láminas de PET son muy bajos, lo que significa que los compuestos activos incorporados como un revestimiento permanecen principalmente en su superficie. El PP posee una mayor capacidad de absorción que el PET y los compuestos activos se atrapan mejor en este sustrato, por esta razón resulta coherente que se encontraran mejores resultados con la lámina de PP que con la de PET para el OR en fase de vapor.

Por lo que respecta al microorganismo diana, parece que, en general, los aceites esenciales son más eficaces frente a los mohos y levaduras que frente a las bacterias y, entre éstas, las Gram-positivas son más sensibles (Burt, 2004). Además, se ha observado que, al menos, ciertos microorganismos influyen en la composición de la atmósfera creada por el aceite esencial. Esto se ha atribuido al efecto de diversas interacciones y/o rutas de biotransformación (López et al., 2007a).

\section{ACTIVIDAD ANTIMICROBIANA POR CONTACTO DIRECTO}

\subsection{OR}

La actividad antimicrobiana del OR por contacto directo frente a las dos cepas, utilizando los dos tipos de láminas (PP y PET) se presenta en la Tabla V.5. El tratamiento de los resultados se llevó a cabo según la norma japonesa JIS Z 2801:2000 (Anónimo, 2000).

Para que este test se considere efectivo deben cumplirse tres requisitos. Los requisitos y el cumplimiento o no de éstos aparecen detallados a continuación:

a) Se debe cumplir la siguiente fórmula para los recuentos de células viables inmediatamente después de la inoculación en los controles (ATOX).

$$
\left(\log _{10 \text { max }}-\log _{10 \text { min }}\right) /\left(\log _{10 \text { mean }}\right) \leq 0,2
$$


Donde,

$\log _{10 \text { max }}$ logaritmo del máximo.

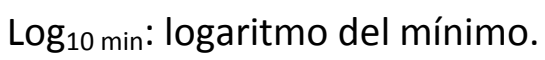

$\log _{10 \text { mean: }}$ logaritmo de la media.

Se aplicó la fórmula para cada una de las cepas y tipos de láminas en los controles inmediatamente después de la inoculación.

CECT5947 / PP: $\left(\log _{10} 1,5 \times 10^{5}-\log _{10} 1,2 \times 10^{5}\right) /\left(\log _{10} 1,33 \times 10^{5}\right)=0,019 \leq 0,2$

CECT5947 / PET: $\left(\log _{10} 1,8 \times 10^{5}-\log _{10} 1,3 \times 10^{5}\right) /\left(\log _{10} 1,57 \times 10^{5}\right)=0,027 \leq 0,2$

M364VO / PP: $\left(\log _{10} 1,1 \times 10^{5}-\log _{10} 9,8 \times 10^{4}\right) /\left(\log _{10} 1,02 \times 10^{5}\right)=0,010 \leq 0,2$

M364VO / PET: $\left(\log _{10} 3 \times 10^{5}-\log _{10} 1,1 \times 10^{5}\right) /\left(\log _{10} 1,9 \times 10^{5}\right)=0,083 \leq 0,2$

Como se puede observar, en todos los casos se cumplió el primero de los requisitos.

b) El promedio de células viables inmediatamente después de la inoculación en los controles (ATOX) debe encontrarse entre 1 y $4 \times 10^{5} \mathrm{ufc} / \mathrm{ml}$. Como se puede observar en la Tabla V.5, este requisito se cumplía, ya que estos promedios se encontraban entre 1,02 y $1,9 \times 10^{5} \mathrm{ufc} / \mathrm{ml}$.

c) El número de células viables en los controles (ATOX) tras 24 horas de incubación no debe ser inferior a $1 \times 10^{4} \mathrm{ufc} / \mathrm{ml}$ en ninguna de las tres réplicas. Como puede verse en la Tabla V.5, este requisito también se cumplía en todos los casos, ya que estos recuentos oscilaban entre $1 \times 10^{4}$ a $1,8 \times 10^{7} \mathrm{ufc} / \mathrm{ml}$.

A continuación se calculó el resultado de la actividad antimicrobiana (R) para las películas recubiertas con formulaciones de diferentes concentraciones de OR. Para ello se aplicó la siguiente fórmula:

$R=\log _{0}(B / C)$

El cálculo del valor R se indica en Material y Métodos y en el píe de la Tabla V.5. 
Tabla V.5. Actividad antimicrobiana ensayada por un método de contacto directo ${ }^{a}$ de diferentes concentraciones de $\operatorname{OR}^{\mathrm{b}}(4 \%, 6 \%$ y $8 \%)$ incorporadas en dos películas de envasado frente a dos cepas de E. coli O157:H7.

\begin{tabular}{|c|c|c|c|c|c|c|}
\hline Cepa & Film & $\begin{array}{c}\text { Concentración } \\
\text { OR }\end{array}$ & $\begin{array}{l}\text { Film control } \\
\text { después de la } \\
\text { inoculación } \\
\text { (ufc/ml) }\end{array}$ & $\begin{array}{c}\text { Film } \\
\text { control a } \\
\text { las } 24 \mathrm{~h} \\
\text { (ufc/ml) }\end{array}$ & $\begin{array}{c}\text { Films } \\
\text { recubiertos } \\
\text { a las } 24 \mathrm{~h} \\
\text { (ufc/ml) }\end{array}$ & $\begin{array}{c}\text { Valor } \\
R^{c}\end{array}$ \\
\hline \multirow{8}{*}{ M364VO'g } & & Barniz ATOX ${ }^{d}$ & $1,02 \times 10^{5 \mathrm{e}}$ & $5,40 \times 10^{6}$ & & \\
\hline & & $4 \%$ & & & $1,40 \times 10^{7}$ & $-0,41$ \\
\hline & $P^{f}$ & $6 \%$ & & & $9,20 \times 10^{6}$ & $-0,23$ \\
\hline & & $8 \%$ & & & $4,47 \times 10^{5}$ & 1,08 \\
\hline & & Barniz ATOX & $1,90 \times 10^{5}$ & $7,00 \times 10^{4}$ & & \\
\hline & & $4 \%$ & & & $S C^{h}$ & \\
\hline & PET $^{\mathrm{i}}$ & $6 \%$ & & & $\mathrm{SC}$ & \\
\hline & & $8 \%$ & & & $\mathrm{SC}$ & \\
\hline \multirow{8}{*}{ CECT $^{\mathrm{j}} 5947$} & & Barniz ATOX & $1,33 \times 10^{5}$ & $1,50 \times 10^{7}$ & & \\
\hline & & $4 \%$ & & & $9,43 \times 10^{6}$ & 0,20 \\
\hline & PP & $6 \%$ & & & SC & \\
\hline & & $8 \%$ & & & SC & \\
\hline & & Barniz ATOX & $1,57 \times 10^{5}$ & $1,20 \times 10^{5}$ & & \\
\hline & & $4 \%$ & & & SC & \\
\hline & PET & $6 \%$ & & & SC & \\
\hline & & $8 \%$ & & & SC & \\
\hline
\end{tabular}

\footnotetext{
${ }^{a}$ Actividad ensayada utilizando la norma japonesa JIS Z 2801:2000

${ }^{\mathrm{b}}$ Aceite esencial de orégano obtenido de Origanum vulgare

'Valor $R$ calculado utilizando la formula $R=\log (B / C)$, siendo $B$ la media de los recuentos de las películas $\sin$ tratar (momento 0 ) y $\mathrm{C}$ la media de los recuentos de las películas tratadas (tras $24 \mathrm{~h}$ de incubación a $37 \stackrel{\text { ㅇ) }}{\text { ) }}$

$\left.{ }^{\mathrm{d} P e l i ́ c u l a s ~ r e c u b i e r t a s ~ s o ́ l o ~ c o n ~ e l ~ b a r n i z ~(~} 0 \% \mathrm{OR}\right)$

${ }^{\mathrm{e}}$ Media de los recuentos obtenidos para tres muestras independientes

${ }^{\mathrm{f} P P}$, Polipropileno

${ }^{g}$ Cepa aislada de leche de oveja

${ }^{\mathrm{h}} \mathrm{SC}$, sin crecimiento. No se recuperaron células viables de las películas activas tras $24 \mathrm{~h}$ de incubación a 37 C 'PET, Polietilentereftalato

${ }^{\mathrm{j}} \mathrm{CECT}$, Colección Española de Cultivos Tipo
}

La norma japonesa JIS Z 2801:2000 se desarrolló para medir la actividad antibacteriana de plásticos y de otros materiales no porosos tratados. En este estudio, tras

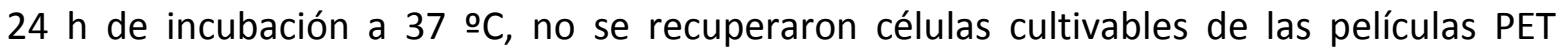
tratadas con 4, 6 y $8 \%$ de OR. Estos resultados ponen de manifiesto que, utilizando el método recogido en la norma japonesa, las películas PET recubiertas con OR mostraban, in vitro, una gran actividad antimicrobiana frente a las dos cepas de $E$. coli 0157:H7 objeto del estudio. Las pruebas con las películas PP demostraron que recubiertas de 6 y $8 \%$ OR también inhibían completamente a la cepa de colección y que recubiertas con $4 \%$ OR 
mostraban una inhibición del $38 \%$ (valor $\mathrm{R}=0,20$ ). Sin embargo, para la cepa de origen ovino, la película PP recubierta de 4 y $6 \%$ OR no sólo no inhibían sino que permitían su crecimiento (valores $\mathrm{R}$ de $-0,41$ y $-0,23$ ) aunque las películas PP $8 \%$ OR produjeron una reducción del 91,7\% (valor $\mathrm{R}$ de 1,08).

Nuestros datos indican que utilizando el método JIS Z 2801:2000, las películas PET OR eran mucho más eficaces que las PP OR, dependiendo el comportamiento de esta última de la cepa objeto del estudio y también de la concentración del compuesto activo.

\section{2. $L A E$}

La Tabla V. 6 muestra la actividad antimicrobiana del LAE incorporado en el barniz ACRIL que recubría las películas PP y PET.

Las películas recubiertas con concentraciones 0 y $4 \%$ LAE no mostraron actividad antimicrobiana frente a ninguna de las cepas. La ausencia de actividad en las películas recubiertas sólo con el barniz ACRIL sugiere que, bajo las condiciones del ensayo (incubación a 37 ㅇ) , las manipulaciones necesarias para preparar las películas sin LAE no afectaban a la actividad antibacteriana de las películas activas. La actividad anti-E. coli de las películas recubiertas con $L A E$, que se manifestaron por la inhibición del crecimiento debajo de la película y alrededor de ella (entre 1 y $2,5 \mathrm{~mm}$ ), demuestran que las películas PET 6\% LAE eran más eficaces que las películas PP 6\% LAE aunque las películas 8\% LAE PET y $8 \%$ LAE PP ocasionaron idénticos resultados (2,5 $\mathrm{mm}$ de zona de inhibición).

Como se observó en las pruebas anteriores, los resultados obtenidos con este método de contacto directo dependen del material de envasado y de la concentración del compuesto activo aunque no del microorganismo diana. 
Tabla V.6. Efecto antimicrobiano ensayado por un método de contacto directo ${ }^{a}$ de diferentes concentraciones de $\operatorname{LAE}(4,6$ y $8 \%)$ incorporadas en dos películas de envasado frente a dos cepas de E. coli O157:H7.

\begin{tabular}{|c|c|c|c|}
\hline Cepa & Película & Concentración LAE & $\begin{array}{l}\text { Zona de inhibición } \\
(\mathrm{mm})^{\mathrm{c}}\end{array}$ \\
\hline \multirow{8}{*}{ M364Vo ${ }^{f}$} & \multirow{4}{*}{$\mathbf{P P}^{\mathrm{e}}$} & Barniz ACRIL $^{d}$ & 0 \\
\hline & & $4 \%$ & 0 \\
\hline & & $6 \%$ & 1 \\
\hline & & $8 \%$ & 2,5 \\
\hline & \multirow{4}{*}{$\mathrm{PET}^{\mathrm{g}}$} & Barniz ACRIL & 0 \\
\hline & & $4 \%$ & 0 \\
\hline & & $6 \%$ & 1,5 \\
\hline & & $8 \%$ & 2,5 \\
\hline \multirow{8}{*}{ CECT $^{\mathrm{h}} 5947$} & \multirow{4}{*}{ PP } & Barniz ACRIL & 0 \\
\hline & & $4 \%$ & 0 \\
\hline & & $6 \%$ & 1 \\
\hline & & $8 \%$ & 2,5 \\
\hline & \multirow{4}{*}{ PET } & Barniz ACRIL & 0 \\
\hline & & $4 \%$ & 0 \\
\hline & & $6 \%$ & 1,5 \\
\hline & & $8 \%$ & 2,5 \\
\hline
\end{tabular}

${ }^{a}$ Actividad ensayada utilizando un método de difusión en agar descrito por Iseppi et al. (2008)

${ }^{b}$ LAE, etil Lauroil Arginato

'Zona de inhibición alrededor de la película de plástico tratado con LAE

${ }^{\mathrm{d}}$ Películas recubiertas sólo con el barniz ( $0 \%$ LAE)

${ }^{\mathrm{e}} \mathrm{PP}$, Polipropileno

${ }^{f}$ Cepa aislada de leche de oveja

${ }^{g} \mathrm{PET}$, Polietilentereftalato

${ }^{\mathrm{h}} \mathrm{CECT}$, Colección Española de Cultivos Tipo

\section{ACTIVIDAD ANTIMICROBIANA EN QUESO ZAMORANO}

La evolución de los recuentos de las dos cepas de E. coli 0157:H7 en lonchas de queso Zamorano inoculadas y mantenidas a refrigeración después de ser colocadas entre dos trozos de PP o PET recubiertos sólo con barniz y con tres concentraciones de cada antimicrobiano se muestra en la Tabla V.7. y en la Figura V.2. El análisis estadístico demostró que los recuentos se veían afectados significativamente $(p<0,05)$ por el tipo de película, el compuesto antimicrobiano, el día de muestreo y la cepa ensayada. 
Tabla V.7. Efecto de dos envases activos frente a dos cepas de E.coli 0157:H7 inoculadas en lonchas de queso Zamorano.

\begin{tabular}{|c|c|c|c|c|c|c|c|c|}
\hline \multirow{2}{*}{$\frac{\text { Film }}{\text { PP }^{c}}$} & \multirow{2}{*}{$\frac{\text { Antimicrobiano }}{O^{d} R^{d}}$} & \multirow{3}{*}{$\begin{array}{c}\text { Concentración } \\
\text { Barniz ATOX } \\
0 \%\end{array}$} & \multicolumn{3}{|c|}{ E.coli 0157:H7 cepa M364VOa } & \multicolumn{3}{|c|}{ E.coli 0157:H7 cepa CECT ${ }^{\mathrm{b}} 5947$} \\
\hline & & & Día 0 & Día 1 & Día 7 & Día0 & Día1 & Día7 \\
\hline & & & ${ }^{\mathrm{ef}} 4,37 \pm 0,11^{1,2}$ & $4,42 \pm 0,06^{1}$ & $4,26 \pm 0,14^{2}$ & $4,33 \pm 0,10^{1}$ & $4,37 \pm 0,19^{1}$ & $4,44 \pm 0,09^{1}$ \\
\hline & & $4 \%$ & $4,31 \pm 0,13^{1}$ & $4,26 \pm 0,7^{1}$ & $4,07 \pm 0,15^{2}$ & $4,40 \pm 0,06^{1}$ & $4,19 \pm 0,07^{2}$ & $3,5 \pm 0,12^{3}$ \\
\hline & & $6 \%$ & $4,32 \pm 0,21^{1,2}$ & $4,35 \pm 0,18^{1}$ & $4,18 \pm 0,25^{2}$ & $4,38 \pm 0,17^{1,2}$ & $4,48 \pm 0,06^{1}$ & $4,32 \pm 0,07^{2}$ \\
\hline & & $8 \%$ & $4,16 \pm 0,13^{1}$ & $4,23 \pm 0,17^{1}$ & $4,16 \pm 0,11^{1}$ & $4,36 \pm 0,09^{1}$ & $4,13 \pm 0,08^{2}$ & $4,30 \pm 0,35^{1}$ \\
\hline & $\mathrm{LAE}^{\mathrm{g}}$ & Barniz ACRIL & & & & & & \\
\hline & & $0 \%$ & $4,41 \pm 0,09^{1}$ & $4,30 \pm 0,08^{1,2}$ & $4,22 \pm 0,06^{2}$ & $4,30 \pm 0,11^{1}$ & $4,29 \pm 0,07^{1}$ & $4,28 \pm 0,12^{1}$ \\
\hline & & $4 \%$ & $4,23 \pm 0,05^{1}$ & $4,12 \pm 0,21^{1}$ & $4,24 \pm 0,03^{1}$ & $4,33 \pm 0,20^{1,2}$ & $4,37 \pm 0,10^{1}$ & $4,19 \pm 0,11^{2}$ \\
\hline & & $6 \%$ & $4,47 \pm 0,12^{1}$ & $4,25 \pm 0,13^{2}$ & $4,22 \pm 0,14^{2}$ & $4,44 \pm 0,08^{1}$ & $4,30 \pm 0,08^{1,2}$ & $4,24 \pm 0,12^{2}$ \\
\hline & & $8 \%$ & $4,38 \pm 0,12^{1}$ & $4,29 \pm 0,05^{1}$ & $4,31 \pm 0,15^{1}$ & $4,47 \pm 0,18^{1}$ & $4,44 \pm 0,11^{1}$ & $4,53 \pm 0,05^{1}$ \\
\hline \multirow[t]{10}{*}{$\mathrm{PET}^{\mathrm{h}}$} & OR & Barniz ATOX & & & & & & \\
\hline & & $0 \%$ & $4,44 \pm 0,07^{1}$ & $4,44 \pm 0,05^{1}$ & $4,38 \pm 0,04^{1}$ & $4,50 \pm 0,09^{1}$ & $4,32 \pm 0,09^{2}$ & $4,31 \pm 0,14^{2}$ \\
\hline & & $4 \%$ & $4,21 \pm 0,03^{1,2}$ & $4,12 \pm 0,05^{1}$ & $4,29 \pm 0,17^{2}$ & $4,45 \pm 0,07^{1}$ & $4,28 \pm 0,15^{2}$ & $3,99 \pm 0,15^{3}$ \\
\hline & & $6 \%$ & $4,46 \pm 0,22^{1}$ & $4,39 \pm 0,19^{1}$ & $4,07 \pm 0,04^{2}$ & $4,53 \pm 0,14^{1}$ & $4,42 \pm 0,07^{1}$ & $4,23 \pm 0,15^{2}$ \\
\hline & & $8 \%$ & $4,29 \pm 0,14^{1}$ & $4,26 \pm 0,12^{1}$ & $4,01 \pm 0,04^{2}$ & $4,36 \pm 0,15^{1}$ & $4,26 \pm 0,17^{1}$ & $4,11 \pm 0,09^{2}$ \\
\hline & LAE & Barniz ACRIL & & & & & & \\
\hline & & $0 \%$ & $4,35 \pm 0,09^{1,2}$ & $4,39 \pm 0,03^{1}$ & $4,21 \pm 0,09^{2}$ & $4,32 \pm 0,07^{1}$ & $4,30 \pm 0,16^{1}$ & $4,21 \pm 0,26^{1}$ \\
\hline & & $4 \%$ & $4,30 \pm 0,09^{1}$ & $4,27 \pm 0,04^{1}$ & $4,12 \pm 0,25^{2}$ & $4,35 \pm 0,05^{1,2}$ & $4,43 \pm 0,14^{1}$ & $4,21 \pm 0,15^{2}$ \\
\hline & & $6 \%$ & $4,47 \pm 0,03^{1}$ & $4,22 \pm 0,10^{2}$ & $4,13 \pm 0,16^{2}$ & $4,44 \pm 0,09^{1}$ & $4,32 \pm 0,06^{1}$ & $4,17 \pm 0,16^{2}$ \\
\hline & & $8 \%$ & $4,50 \pm 0,07^{1}$ & $4,23 \pm 0,17^{2}$ & $4,30 \pm 0,05^{2}$ & $4,44 \pm 0,08^{1}$ & $4,40 \pm 0,12^{1,2}$ & $4,28 \pm 0,09^{2}$ \\
\hline
\end{tabular}

${ }^{a}$ Cepa aislada de leche de oveja

${ }^{\mathrm{b}} \mathrm{CECT}$, Colección Española de Cultivos Tipo

${ }^{\mathrm{C} P \mathrm{P}, \text { Polipropileno }}$

${ }^{\mathrm{d}} \mathrm{OR}$, aceite esencial de orégano obtenido de Origanum vulgare

${ }^{\text {e}}$ Cada media desviación estándar corresponde a seis determinaciones

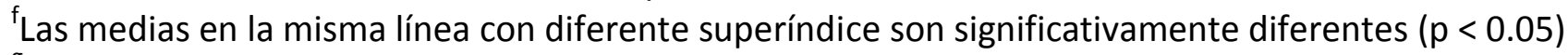

${ }^{g}$ LAE, Etil Lauroil Arginato

${ }^{\mathrm{h}} \mathrm{PET}$, Polietilentereftalato 


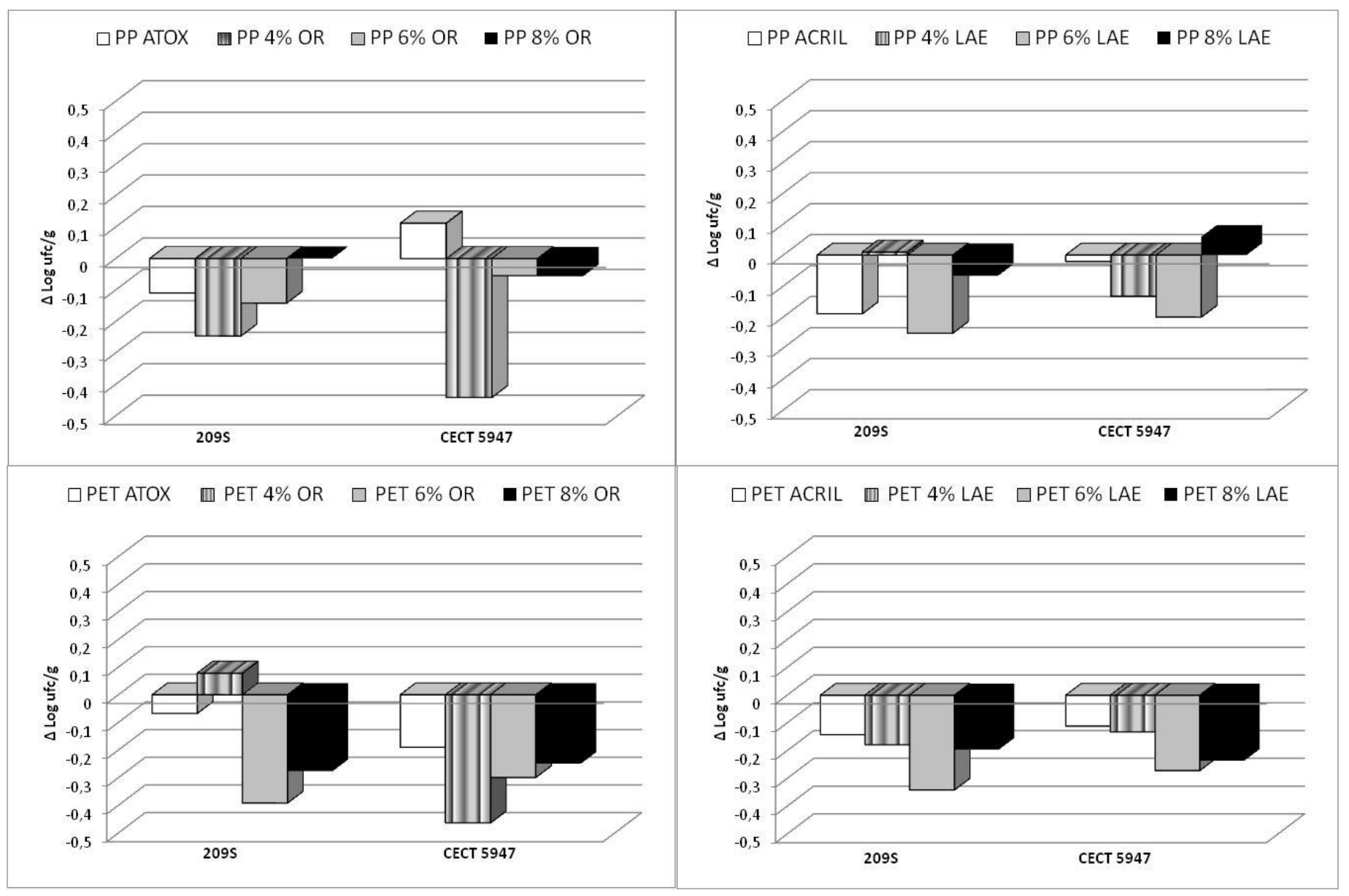

Figura V.2. Evolución de los recuentos (tras 7 días de almacenamiento) de las dos cepas CECT 5947 y M364VO inoculadas en queso y en contacto directo con láminas de PP y PET recubiertas con diferentes concentraciones de OR y LAE.

Tras siete días de almacenamiento a refrigeración, la película 4\% OR PP disminuía de forma estadísticamente significativa $(p<0,05)$ los recuentos de ambas cepas de $E$. coli 0157:H7. Sin embargo, esta misma película recubierta con $6 \%$ y $8 \%$ OR no reducía los recuentos de forma significativa $(p>0,05)$. En conjunto, estos resultados no coinciden con los obtenidos en las pruebas in vitro (ensayo en fase vapor y la norma japonesa JIS Z 2801:2000) ya que, en ambos casos, la inhibición de las películas PP aumentaba al incrementarse la concentración de OR (Tablas V. 4 y V.5).

En el queso inoculado, las películas LAE PP solo redujeron significativamente los niveles de E. coli 0157:H7 cuando estaban recubiertas con el 6\% de LAE aunque in vitro, empleando la técnica de contacto directo (Tabla V.6), la zona de mayor inhibición correspondía a las películas 8\% LAE PP. La disminución observada en queso envasado en $4 \%$ OR PP y $6 \%$ LAE PP, aunque estadísticamente significativa, es tan baja que podría 
considerarse de escaso interés práctico. Estos datos sugieren que los envases antimicrobianos basados en la liberación de OR y LAE cuando la película es de PP no son eficaces frente a las cepas utilizadas por nosotros cuando éstas se inoculan en queso Zamorano. En estudios similares realizados con otra bacteria patógena Gram-negativa mesófila (Salmonella) inoculada en diferentes alimentos, los resultados de la inhibición han sido mucho más eficaces (Muriel-Galet et al., 2012a; Muriel-Galet et al., 2012b).

Cuando se trataba de las películas PET recubiertas de OR, estas reducían significativamente $(p<0,05)$ los niveles de las dos cepas ensayadas cuando las lonchas de queso estaban envasadas con 4\% OR (cepa de colección), 6\% y 8\% (ambas cepas). Resultados parecidos se observaron cuando las películas PET se recubrieron con LAE. En este caso, la película 4\% LAE PET inhibió significativamente $(p<0,05)$ a la cepa aislada de leche de oveja pero no a la cepa de colección. Debe señalarse que las películas $6 \%$ OR PET y 6\% LAE PET fueron más eficaces que las películas $8 \%$ OR PET y $8 \%$ LAE PET. Nuestros resultados sugieren que para el modelo de queso Zamorano, la actividad antimicrobiana de la película PET era superior a la de la película PP.

Diversos estudios acerca de la eficacia de películas con actividad antimicrobiana ponen de manifiesto que su actividad utilizando métodos in vitro es muy superior a la observada cuando se utilizan alimentos. Este hecho es muy frecuente y se debe no solo al microorganismo objeto del ensayo sino también al efecto interactivo de gran número de factores (Han, 2005). Entre ellos se encuentran: ciertas características del alimento como son el $\mathrm{pH}$, la $\mathrm{a}_{\mathrm{w}}$, el contenido en grasa y proteína, los conservantes, incluidos los antioxidantes, otros aditivos, la sal y también parámetros externos como la temperatura de almacenamiento y la composición de la atmósfera. Además, cada alimento posee su flora característica (Quintavalla \& Vicini, 2002; Burt, 2004; Han, 2005). Nuestros datos acerca de las propiedades físico-químicas del queso Zamorano, tras dos meses de maduración, indican que su contenido en grasa es de ca. 45 \% y el de proteína del 25\%. Su pH es de 5,3; su $a_{w}$ de 0,95 y su contenido en $\mathrm{NaCl}$ de casi el 2\%. La microflora dominante está constituida por bacterias acidolácticas (BAL) que suelen superar 9 ufc log/g. De todas formas hay que recordar que, aunque E. coli 0157:H7 es una bacteria mesófila que, aparentemente, es incapaz de multiplicarse a temperaturas $\leq 7 \stackrel{\circ}{\circ}$, algunas cepas poseen 
mecanismos genéticos específicos que les permiten sobrevivir y multiplicarse a bajas temperaturas (Vidovic et al., 2011).

\section{ANÁLISIS SENSORIAL}

Para establecer si existían diferencias significativas entre las muestras se utilizó, como ya se indicó en el apartado "Material y Métodos", la Norma ISO 8587:2010 (Anónimo, 2010). Para ello, en primer lugar, se resumieron en tablas las evaluaciones anotadas en los formularios de respuestas por cada uno de los jueces para cada prueba, indicando el orden de las muestras e incluyendo un símbolo de igualdad entre muestras consideradas iguales. A continuación se decodificaron las muestras y se calcularon las sumas de las ordenaciones para cada una de ellas, comparando los resultados de estas sumas se valoró si existían diferencias entre las muestras calculando F' (ya que uno o más jueces asignaron a dos o más muestras el mismo número de orden) utilizando las siguientes fórmulas:

$$
F_{\text {test }}=\frac{12}{j \cdot p(p+1)}\left(R_{1}^{2}+R_{2}^{2}+\cdots+R_{p}^{2}\right)-3 j(p+1)
$$

Donde:

- j: número de jueces.

- p: número de muestras.

- $\quad R_{1}, R_{2}, \ldots R_{p}$ : son las sumas de las ordenaciones atribuidas al conjunto $p$ de muestras para los j jueces.

$$
F^{F^{\prime}=\frac{F}{1-\left\{E /\left[j \cdot p\left(p^{2}-1\right)\right]\right\}}}
$$

Siendo $\mathrm{n}_{1}, \mathrm{n}_{2}, \ldots \mathrm{n}_{\mathrm{k}}$ el número de muestras con el mismo número de ordenación en la evaluación de distintos jueces $(1,2, \ldots k)$.

Para saber si existían diferencias significativas entre las diferentes muestras se comparó el valor de $F^{\prime}$ con el valor crítico de distribución de chi-cuadrado con un nivel de significación $(\alpha)$ de 0,05 . Este es un valor tabulado que aparece en la norma ISO de referencia y que para nuestros análisis sensoriales con siete muestras/día era $\mathrm{F}^{\prime}=12,59$. 
En caso de que existieran diferencias significativas entre las muestras se procedió a la identificación de los pares de muestras que diferían significativamente entre sí. Para ello, se calculó la Mínima Diferencia Significativa (MDS) para el riesgo asumido. Con un riesgo $\alpha=0,05$ (es decir, $5 \%$ de riesgo), el valor de z a considerar para el cálculo de MDS (correspondiente a una probabilidad normal bilateral de $\alpha$ ) es igual a 1,96. Este riesgo se conoce como el riesgo por comparación o riesgo individual.

$$
M D S=z \sqrt{\frac{j \cdot p(p+1)}{6}}
$$

Si la diferencia observada entre las sumas de ordenaciones de dos productos es superior o igual a la MDS, entonces se concluye que los dos productos han obtenido ordenaciones significativamente diferentes.

Seguidamente se da cuenta de los resultados.

\subsection{Análisis sensorial del queso envasado en láminas de PP recubiertas con formulaciones de OR}

Entre las muestras, se obtuvo un valor $F^{\prime}=48,58$. Como este es superior a $F^{\prime}=12,59$, existían diferencias significativas $(p<0,05)$ entre las muestras evaluadas en este análisis sensorial.

A continuación se compararon pares de muestras. En primer lugar se compararon las lonchas de queso sin envasar con el resto de las lonchas, concluyendo que las primeras presentaban diferencias significativas $(p<0,05)$ con el queso envasado en contacto directo con láminas de PP recubiertas con las formulaciones de OR (4, 6 y 8\%) almacenados durante 24 horas. También presentaban diferencias significativas $(p<0,05)$ con el queso envasado en contacto con láminas recubiertas con la formulación de OR al $6 \%$ y almacenadas durante una semana.

Posteriormente se compararon las lonchas de queso en contacto con láminas de PP recubiertas con OR tras 24 horas y una semana de almacenamiento. El queso almacenado durante 24 horas no presentó diferencias significativas $(p>0,05)$ con el queso envasado durante una semana a igual concentración de OR. 
En los comentarios, los jueces señalaron que les resultó difícil realizar la cata debido al número de muestras (les pareció elevado), y a que el sabor a orégano persistía bastante. Nuestros datos indican que para las películas OR PP, los jueces detectaron el orégano en las muestras envasadas a las 24 horas y, algo menos, a los siete días de almacenamiento.

\subsection{Análisis sensorial del queso envasado en láminas de PET recubiertas con formulaciones de OR}

En este caso se obtuvo una $F^{\prime}=9,70$ (valor inferior al tabulado $-F^{\prime}=12,59-$ ) por lo que no existían diferencias significativas $(p>0,05)$ entre las muestras valoradas en este análisis sensorial.

En los comentarios los jueces indicaron que les había resultado más difícil que el análisis de las muestras en contacto con láminas OR PP pero que se percibía el sabor a orégano. Por tanto, se puede concluir que, aunque como en el caso de las láminas OR PP, se percibía el sabor a orégano, este fue menos intenso, ya que no se detectaron diferencias significativas entre las muestras.

\subsection{Análisis sensorial del queso envasado en láminas de PP recubiertas con formulaciones de LAE}

En este caso se obtuvo una $F^{\prime}=7,21$. Este valor es inferior al valor tabulado $\left(F^{\prime}=\right.$ $12,59)$ con lo que se pudo concluir que no existían diferencias significativas $(p>0,05)$ entre las muestras valoradas en este análisis sensorial.

En los comentarios los jueces también señalaron que no encontraron diferencias entre las muestras.

\subsection{Análisis sensorial del queso envasado en láminas de PET recubiertas con formulaciones de LAE}

En este caso se obtuvo una $\mathrm{F}^{\prime}=12,3$. Este resultado también era inferior al valor tabulado $\left(F^{\prime}=12,59\right)$ por lo que se pudo concluir que no existían diferencias significativas $(p>0,05)$ entre las muestras estudiadas. 
En los comentarios los jueces reflejaron que, al igual que en el caso anterior, no encontraron diferencias entre las muestras.

Los resultados del análisis sensorial indican que LAE y/o PET no afectan significativamente a las características organolépticas del queso Zamorano. Aunque en el caso de las láminas de PET recubiertas con las diferentes formulaciones de OR los jueces no detectaron diferencias significativas entre las muestras, sí que detectaron sabor a OR por lo que no sería recomendable su uso en este caso.

En conjunto, los datos del trabajo recogido en este capítulo ponen de manifiesto que las películas PP y PET recubiertas con OR y LAE son eficaces para inhibir cepas de $E$. coli O157:H7, tanto de colección como de origen ovino, cuando se prueban in vitro. Sin embargo, en el alimento ensayado (queso Zamorano) su efecto es menor, dependiendo principalmente de la película y también del agente antimicrobiano. No obstante, las películas PET recubiertas de concentraciones iguales o superiores al 6\% LAE podrían ser útiles para reducir los niveles de $E$. coli $0157: \mathrm{H} 7$ en queso de oveja madurado. 
Capítulo V. Bibliografía

\section{BIBLIOGRAFÍA}

1. Anónimo. 2010. UNE-ISO 8587:2010. Análisis sensorial. Metodología. Ordenación. International Organization for Standardization. Ginebra.

2. Anónimo. 2009. Reglamento (CE) № 450/2009 de la Comisión de 29 de Mayo de 2009 sobre materiales y objetos activos e inteligentes destinados a entrar en contacto con alimentos. D. O., L 135: 3-11.

3. Anónimo. 2000. JIS Z 2801:2000. Antimicrobial products- Test for antimicrobial activity and efficacy. Japanese Standards Association.

4. Becerril, A., Manso, S., Nerin, C. and Gómez-Lus, R. 2013. Antimicrobial activity of Lauroyl Arginate Ethyl (LAE), against selected food-borne bacteria. Food Control, 32: 404-408.

5. Becerril, R., Gomez-Lus, R., Goni, P., Lopez, P. and Nerin, C. 2007. Combination of analytical and microbiological techniques to study the antimicrobial activity of a new active food packaging containing cinnamon or oregano against $E$. coli and S. aureus. Anal. Bioanal Chem., 388: 1003-1011.

6. Burt, S. 2004. Essential oils: their antibacterial properties and potential applications in foods-a review. Int. J. Food Microbiol., 94: 223-253.

7. Burt, S. A. \& Reinders, R. D. 2003. Antibacterial activity of selected plant essential oils against Escherichia coli 0157: H7. Lett. Appl. Microbiol., 36: 162-167. 
Capítulo V. Bibliografía

8. Caro, I. \& García-Armesto, M. R. 2007. Occurrence of Shiga toxin-producing

Escherichia coli in a Spanish raw ewe's milk cheese. Int. J. Food Microbiol., 116: 410413.

9. Caro, I., Mateo, J., Rúa, J. and García-Armesto, M. R. 2011. Occurrence of Escherichia coli $\mathrm{O} 157, \mathrm{O} 111$ and $\mathrm{O} 26$ in raw ewe's milk and performance of two enrichment broths and two plating media used for its assessment. Int. J. Food Microbiol., 146: 84-87.

10. Cha, D. S. \& Chinnan, M. S. 2004. Biopolymer-based antimicrobial packaging: a review. Crit. Rev. Food Sci. Nutr., 44: 223-237.

11. Espié, E., Vaillant, V., Mariani-Kurkdjian, P., Grimont, F., Martin-Schaller, R., De Valk, H. and Vernozy-Rozand, C. 2006. Escherichia coli 0157 outbreak associated with fresh unpasteurized goats' cheese. Epidemiol. Infect., 134: 143-146.

12. Farrokh, C., Jordan, K., Auvray, F., Glass, K., Oppegaard, H., Raynaud, S., Thevenot, D., Condron, R., De Reu, K. and Govaris, A. 2013. Review of Shiga-toxin-producing Escherichia coli (STEC) and their significance in dairy production. Int. J. Food Microbiol., 162 (2): 190-212.

13. Ferens, W. A. \& Hovde, C. J. 2011. Escherichia coli O157: H7: animal reservoir and sources of human infection. Foodborne Pathog. Dis., 8: 465-487.

14. Gutiérrez, J., Rodríguez, G., Barry-Ryan, C. and Bourke, P. 2008. Efficacy of plant essential oils against foodborne pathogens and spoilage bacteria associated with ready-to-eat vegetables: antimicrobial and sensory screening. J. Food Prot., 71: 18461854. 
Capítulo V. Bibliografía

15. Gutiérrez, L., Batlle, R., Sánchez, C. and Nerín, C. 2010. New approach to study the mechanism of antimicrobial protection of an active packaging. Foodborne Pathog. Dis., 7: 1063-1069.

16. Han, J. H. 2005. Introduction to active food packaging technologies. In: Han, J. H. (Ed.), Innovations in food packaging. Academic Press, Londres, pp. 80-107.

17. Higueras, L., López-Carballo, G., Hernández-Muñoz, P., Gavara, R. and Rollini, M. 2013. Development of a novel antimicrobial film based on chitosan with LAE (ethyl-Na-dodecanoyl-L-arginate) and its application to fresh chicken. Int. J. Food Microbiol., 165: 339-345.

18. Iseppi, R., Pilati, F., Marini, M., Toselli, M., de Niederhäusern, S., Guerrieri, E., Messi, P., Sabia, C., Anacarso, I. and Bondi, M. 2008. Anti-listerial activity of a polymeric film coated with hybrid coatings doped with Enterocin 416K1 for use as bioactive food packaging. Int. J. Food Microbiol., 123: 281-287.

19. López, P., Sánchez, C., Batlle, R. and Nerín, C. 2007a. Vapor-Phase Activities of Cinnamon, Thyme, and Oregano Essential Oils and Key Constituents against Foodborne Microorganisms. J. Agric. Food Chem., 55: 4348-4356.

20. López, P., Sánchez, C., Batlle, R. and Nerín, C. 2007b. Development of Flexible Antimicrobial Films Using Essential Oils as Active Agents. J. Agric. Food Chem., 55: $8814-8824$. 
Capítulo V. Bibliografía

21. Marino, M., Bersani, C. and Comi, G. 2001. Impedance measurements to study the antimicrobial activity of essential oils from Lamiaceae and Compositae. Int. J. Food Microbiol., 67: 187-195.

22. Meng, J., Jeffrey, T. L., Zhao, T. and Doyle, M. P. 2013. Enterohemorrhagic Escherichia coli. In: Doyle, M. P. and Buchanan, R. L. (Eds.), Food Microbiology: Fundamentals and Frontiers. American Society for Microbiology Press, Washington DC, USA, pp. 287-309.

23. Muriel-Galet, V., López-Carballo, G., Gavara, R. and Hernández-Muñoz, P. 2012a. Antimicrobial food packaging film based on the release of LAE from EVOH. Int. J. Food Microbiol., 157: 239-244.

24. Muriel-Galet, V., Cerisuelo, J. P., López-Carballo, G., Lara, M., Gavara, R. and Hernández-Muñoz, P. 2012b. Development of antimicrobial films for microbiological control of packaged salad. Int. J. Food Microbiol., 157: 195-201.

25. Nataro, P. J. \& Kaper, J. B. 1998. Diarrheagenic Escherichia coli. Clin. Microbiol. Rev., 11: 142-201.

26. Nerín, C. \& Garcés, O. 2006. Antimicrobial packaging based on the use of natural extracts and the process to obtain this packaging. European Patent Application EP 1 657181 A1.

27. Quintavalla, S. \& Vicini, L. 2002. Antimicrobial food packaging in meat industry. Meat Sci., 62: 373-380. 
Capítulo V. Bibliografía

28. Rey, J., Sánchez, S., Blanco, J. E., Hermoso de Mendoza, J., Hermoso de Mendoza, M., García, A., Gil, C., Tejero, N., Rubio, R. and Alonso, J. M. 2006. Prevalence, serotypes and virulence genes of Shiga toxin-producing Escherichia coli isolated from ovine and caprine milk and other dairy products in Spain. Int. J. Food Microbiol., 107: 212-217.

29. Rodríguez, A., Nerín, C. and Batlle, R. 2008. New cinnamon-based active paper packaging against Rhizopusstolonifer food spoilage. J. Agric. Food Chem., 56: 63646369.

30. Rodríguez, E., Seguer, J., Rocabayera, X. and Manresa, A. 2004. Cellular effects of monohydrochloride of I-arginine, Na-lauroyl ethylester (LAE) on exposure to Salmonella typhimurium and Staphylococcus aureus. J. Appl. Microbiol., 96: 903-912.

31. Rooney, M. L. 2005. Introduction to active food packaging technologies. In: Han, J. H. (Ed.), Innovations in Food Packaging. Academic Press, Londres, pp. 63-79.

32. Sacchetti, G., Maietti, S., Muzzoli, M., Scaglianti, M., Manfredini, S., Radice, M. and Bruni, R. 2005. Comparative evaluation of 11 essential oils of different origin as functional antioxidants, antiradicals and antimicrobials in foods. Food Chem., 91: 621632.

33. Suppakul, P., Miltz, J., Sonneveld, K. and Bigger, S. W. 2003. Active packaging technologies with an emphasis on antimicrobial packaging and its applications. J. Food Sci., 68: 408-420. 
Capítulo V. Bibliografía

34. Theinsathid, P., Visessanguan, W., Kruenate, J., Kingcha, Y. and Keeratipibul, S. 2012. Antimicrobial Activity of Lauric Arginate-Coated Polylactic Acid Films against Listeria monocytogenes and Salmonella Typhimurium on Cooked Sliced Ham. J. Food Sci., 77: M142-M149.

35. Turgis, M., Vu, K. D., Dupont, C. and Lacroix, M. 2012. Combined antimicrobial effect of essential oils and bacteriocins against foodborne pathogens and food spoilage bacteria. Food Res. Int., 48: 696-702.

36. Vidovic, S., Mangalappalli-Illathu, A. K. and Korber, D. R. 2011. Prolonged cold stress response of Escherichia coli 0157 and the role of rpoS. Int. J. Food Microbiol., 146: 163-169. 
Capítulo V. Bibliografía 
CONCLUSIONES 

PRIMERA. A pesar de la eficacia del sistema inmunoenzimático Prospect ${ }^{\circledR}$ Shiga Toxin para la detección de toxinas Shiga en muestras de heces, este trabajo demuestra que no resulta útil para su detección en leche de oveja.

SEGUNDA. Aunque la presencia de genes que codifican para las toxinas Shiga parece ser frecuente en las muestras de leche de oveja, el aislamiento de cepas de Escherichia coli productoras de estas toxinas es bajo. Sin embargo, la leche de oveja es una fuente importante de cepas de Escherichia coli enteropatogénicas.

TERCERA. La incidencia de cepas de Escherichia coli productoras de toxinas Shiga en muestras de heces, leche y agua no parece estar relacionada con las puntuaciones obtenidas por las explotaciones en las auditorías realizadas para su certificación.

CUARTA. El Dryspot E. coli 0157 test es útil para la identificación de cepas de Escherichia coli 0157, ya que todas aquellas que fueron positivas se confirmaron por técnicas convencionales, albergando además el gen que codifica para el antígeno somático 0157.

QUINTA. La leche de oveja, las heces de estos animales y el agua de bebida contienen cepas de Escherichia coli productoras de toxinas Shiga. El agua de bebida contaminada puede ser la causa de la diseminación dentro del rebaño. Por otro lado, teniendo en cuenta las similitudes observadas en el perfil de genes de virulencia y con la técnica de electroforesis en gel de campo pulsado, el origen más probable de la contaminación de la leche son las heces, bien directa o indirectamente.

SEXTA. Las similitudes halladas entre las cepas de Escherichia coli productoras de toxina Shiga de origen ovino y algunas de origen humano en los genes de virulencia, el perfil de bandas obtenido con la técnica de electroforesis en gel de campo pulsado y el fagotipo en el caso de cepas 0157:H7, confirma que los animales de la especie ovina constituyen un reservorio de esta bacteria y que su leche y productos derivados no tratados térmicamente pueden suponer un riesgo en relación con esta bacteria.

SÉPTIMA. La incidencia de cepas 0157:H7 es menor que la de las cepas no-0157. Sin embargo, todas ellas poseían genes de virulencia, siendo algunas resistentes a uno o 
varios agentes antimicrobianos. Por tanto es importante utilizar correctamente los tratamientos veterinarios para así reducir al mínimo la aparición de resistencias.

OCTAVA. La relación encontrada, tanto con la técnica "multilocus sequence typing" como en los patrones de bandas obtenidos con la técnica de electroforesis en gel de campo pulsado, entre cepas de Escherichia coli enteropatogénicas atípicas sugieren que el agua de las explotaciones de ovino puede constituir una vía importante de contaminación de la leche por estas cepas.

NOVENA. La presencia en leche de ovino de cepas de Escherichia coli enteropatogénicas atípicas relacionadas con otras causantes de enfermedad en humanos sugiere una posible ruta de transmisión de estos patógenos emergentes con el consiguiente riesgo para la salud.

DÉCIMA. Las bacterias presentes de forma natural en la leche (principalmente bacterias acidolácticas) parecen ejercer un efecto inhibidor sobre el crecimiento de Escherichia coli productor de toxinas Shiga, aunque no garantizan su ausencia tal y como muestran las diferencias observadas en los recuentos de estas cepas durante el almacenamiento de leche cruda y pasterizada.

UNDÉCIMA. Los recuentos de Escherichia coli productor de toxinas Shiga en leche almacenada a las temperaturas exigidas por la normativa actual de la Unión Europea disminuyen, se mantienen o aumentan. Por tanto, estas temperaturas no garantizan la ausencia de estas cepas en la leche, lo que puede suponer un riesgo si se destina a la fabricación de productos lácteos no tratados térmicamente.

DUODÉCIMA. El comportamiento de Escherichia coli 0157 durante la elaboración y maduración del queso tipo Zamorano sugiere que, aunque disminuye el nivel inicialmente presente, la bacteria puede permanecer viable y representar un riesgo para el consumidor teniendo en cuenta su baja dosis infectiva.

DECIMOTERCERA. Las láminas de polipropileno y polietilentereftalato recubiertas con formulaciones de aceite esencial de orégano y etil lauroil arginato son eficaces para inhibir in vitro cepas de Escherichia coli 0157:H7, tanto de colección como de origen 
ovino. Sin embargo, en queso Zamorano almacenado en contacto directo con éstas láminas el efecto es menor debido a las características del alimento, aunque las películas de polietilentereftalato recubiertas de concentraciones iguales o superiores al 6\% de etil lauroil arginato podrían ser útiles para reducir los niveles de Escherichia coli 0157:H7 en queso de oveja madurado. Además, el etil lauroil arginato no afecta significativamente a las características organolépticas de este producto lácteo. 
Conclusiones 
ANEXOS 



\title{
Genetic Characterization of Atypical Enteropathogenic Escherichia coli Isolates from Ewes' Milk, Sheep Farm Environments, and Humans by Multilocus Sequence Typing and Pulsed-Field Gel Electrophoresis
}

\author{
Verónica Otero, José-María Rodríguez-Calleja, Andrés Otero, María-Luisa García-López, Jesús A. Santos \\ Department of Food Hygiene and Food Technology, Veterinary Faculty, University of León, León, Spain
}

A collection of 81 isolates of enteropathogenic Escherichia coli (EPEC) was obtained from samples of bulk tank sheep milk (62 isolates), ovine feces ( 4 isolates), sheep farm environment (water, 4 isolates; air, 1 isolate), and human stool samples ( 9 isolates). The strains were considered atypical EPEC organisms, carrying the eae gene without harboring the pEAF plasmid. Multilocus sequence typing (MLST) was carried out with seven housekeeping genes and 19 sequence types (ST) were detected, with none of them having been previously reported for atypical EPEC. The most frequent ST included 41 strains isolated from milk and human stool samples. Genetic typing by pulsed-field gel electrophoresis (PFGE) resulted in 57 patterns which grouped in 24 clusters. Comparison of strains isolated from the different samples showed phylogenetic relationships between milk and human isolates and also between milk and water isolates. The results obtained show a possible risk for humans due to the presence of atypical EPEC in ewes' milk and suggest a transmission route for this emerging pathogen through contaminated water.

E nteropathogenic Escherichia coli (EPEC) is an important group of diarrheagenic E. coli, being responsible for outbreaks of infant diarrhea in developing countries, with fatality rates as high as $30 \%$ (1), and increasingly being implicated as a causative agent of diarrhea in developed countries, affecting all age groups $(2,3)$. This epidemiological difference between developing and developed countries is linked to the characteristics of EPEC strains. Typical EPEC organisms, defined as strains of E. coli that produce an attaching and effacing lesion in intestinal cells, carry the EAF virulence plasmid, and do not produce Shiga-like toxins, are predominant in developing countries, whereas atypical EPEC isolates, which are similar to typical EPEC isolates but do not possess the EAF virulence plasmid, are emerging pathogens in developed countries $(2,4,5)$.

The reservoir of typical EPEC strains is thought to be human carriers (3), and those strains are rarely isolated from animals (2). In contrast, atypical EPEC strains are readily isolated from humans and animals; there is no confirmation of direct transmission from animals to humans, but the fact that strains belonging to the same serogroups have been found in animal and human diseases suggests that animals can be an important reservoir of atypical EPEC that can be transmitted to humans (5) and also from humans to animals (6). The isolation from food production animals and farm environments has been reported (7-9), and milk and dairy products appear to be regularly contaminated with EPEC strains (10-14), even though other studies failed to isolate EPEC from milk samples $(7,15)$. Taking into account that farm animals and milk and dairy products carry atypical EPEC strains, it can be presumed that a possible route of transmission is from animals to food and then to humans.

The aim of this study was to analyze the presence of atypical EPEC strains in sheep milk and in the environment of sheep farms and to compare the phylogenetic relationships of isolates obtained from these samples and isolates obtained from humans to search for possible routes of transmission of EPEC to humans.

\section{MATERIALS AND METHODS}

Sample collection. Bulk tank ewes' milk samples were obtained from 388 farms located along 10 different milk collection routes in northwest Spain. Milk samples of $100 \mathrm{ml}$ were aseptically taken in sterile containers.

Additional samples from air, water, feed, and feces were taken from 10 selected farms (one farm at the end of each collection route). Tenliter air samples were collected using a microbial air sampler (Biotest Hycon, Dreieich, Germany) fitted with a tryptone soya agar (TSA; Oxoid, Basingstoke, United Kingdom) strip. Water troughs and feed (silage) samples were taken in sterile containers of $500 \mathrm{ml}$ and $250 \mathrm{~g}$, respectively. Sampling of feces in farm premises was done with boot swabs by following the protocol outlined by the EU for monitoring the reduction of Salmonella in laying hens. In brief, boot swabs, moistened with a solution of $0.1 \%$ peptone and $0.9 \% \mathrm{NaCl}$, were used to walk through the premises using a route that produced a sample for all parts of the farm. A minimum of four samples (two pairs of boot swabs) were collected, with the swabs being changed every 100 steps. Boot swabs were removed carefully and stored in sterile zipper storage bags for transport to the laboratory.

Milk and farm environment samples were immediately transported to the laboratory in an insulated cooler. Temperature on arrival to the laboratory was always under $8^{\circ} \mathrm{C}$.

Suspected diarrheagenic E. coli isolates from stool samples of patients with gastrointestinal disease were kindly provided by the Microbiology Service of the University Hospital of León.

Sample processing. Fifty milliliters of milk was cultured in $450 \mathrm{ml}$ of tryptone soya broth (TSB; Oxoid) plus $0.6 \%$ yeast extract (TSBYE; Oxoid) at $42^{\circ} \mathrm{C}$ for $18 \mathrm{~h}$. An aliquot of the enriched sample was streaked onto CT-SMAC (Oxoid) plates and incubated at $37^{\circ} \mathrm{C}$ for 24 h. Pink (sorbitol fermenters) and colorless (nonfermenters) colonies

Received 4 June 2013 Accepted 12 July 2013

Published ahead of print 19 July 2013

Address correspondence to Jesús A. Santos, j.santos@unileon.es.

Copyright $\odot$ 2013, American Society for Microbiology. All Rights Reserved.

doi:10.1128/AEM.01809-13 
TABLE 1 Target genes and primer sequences for the PCR detection of EPEC gene markers

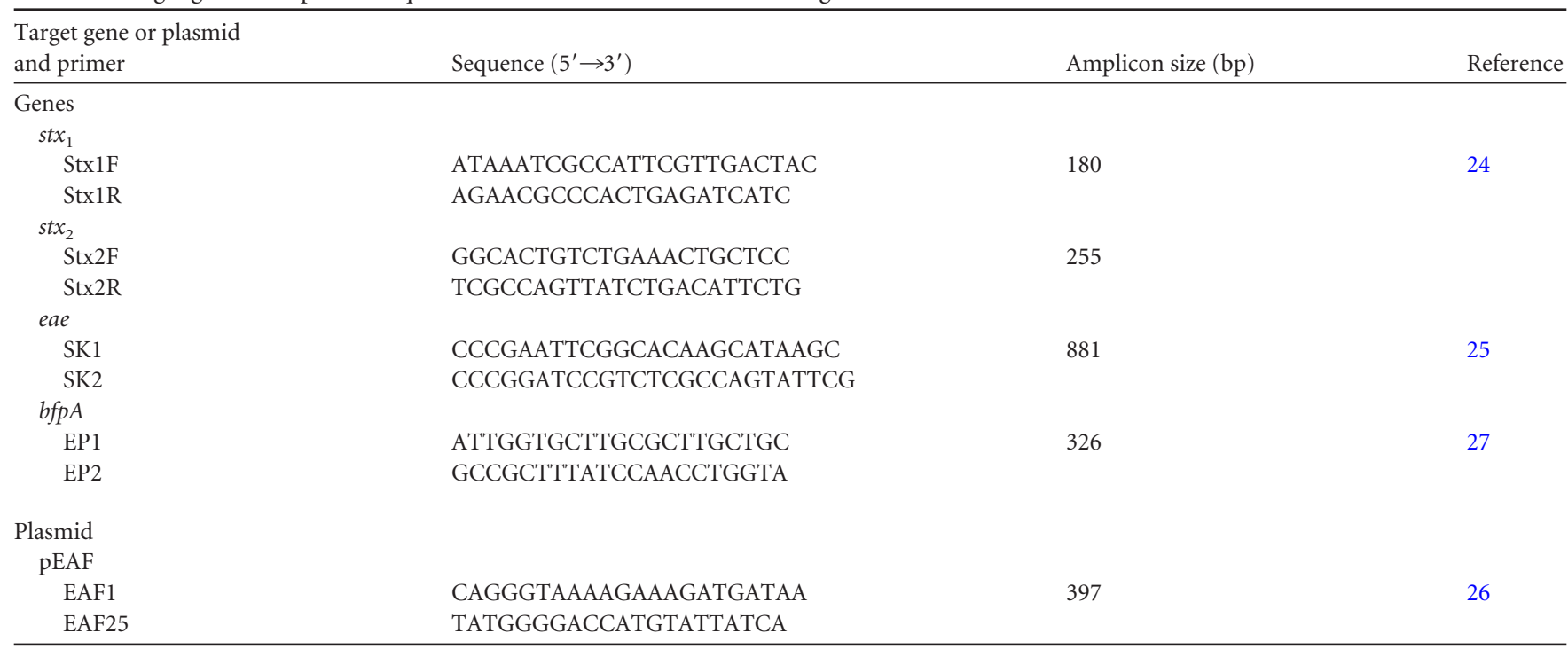

were picked and preserved at $-40^{\circ} \mathrm{C}$ in TSB plus $40 \%$ glycerol for further characterization.

TSA strips from the air sampling were homogenized with $50 \mathrm{ml}$ of TSBYE in a Masticator blender (IUL SA, Barcelona, Spain). Water samples $(250 \mathrm{ml})$ were filtered through sterile $0.45-\mu \mathrm{m}$ filters, which were then incubated in $50 \mathrm{ml}$ TSBYE. Twenty five $\mathrm{g}$ of feed pellets was blended with $225 \mathrm{ml}$ of TSBYE. Boot swabs were unpacked and placed in $225 \mathrm{ml}$ of TSBYE. All cultures were incubated and plated onto CT-SMAC as described above.

PCR detection of enteropathogenic E. coli. Presumptive EPEC isolates were cultured in TSB at $37^{\circ} \mathrm{C}$ for $18 \mathrm{~h}$, and DNA was released by heat lysis. The template DNA was screened by PCR for the presence of the target genes $s t x_{1}, s t x_{2}, e a e$, and $b f p A$, as well as plasmid pEAF, using the primers described in Table 1. PCR was carried out in a Mastercycler Personal (Eppendorf-Netheler-Hinz GmbH, Hamburg, Germany) in a final volume of $25 \mu \mathrm{l}$ and an annealing temperature of $56^{\circ} \mathrm{C}$. PCR products ( 5 $\mu l$ ) were analyzed by $1 \%$ agarose gel electrophoresis and viewed after ethidium bromide staining under UV light.

MLST. Multilocus sequence typing (MLST) was carried out by amplifying and sequencing seven housekeeping genes ( $\operatorname{arc} A, c y a A, f a d D, i c d A$, lys $P, m t l D$, and $r p o S$ ), as described by Moura et al. (6), by following the protocol detailed at the EcMLST website (http://shigatox.net/new/tools /ecmlst.html). PCR products were purified with a NucleoSpin gel and PCR cleanup kit (Macherey-Nagel, Düren, Germany). Both strands were sequenced in a Megabace 500 sequencer (Amersham Biosciences, Piscataway, $\mathrm{NJ}$ ).

Raw sequences were visually reviewed and edited using the Chromas Lite 2.1 software (Technelysium, South Brisbane, Queensland, Australia) and aligned with the ClustalW algorithm of the MEGA5 software (16). Each gene locus was assigned an allele number by searching the EcMLST database. New allele numbers were assigned by the curator of the database upon submission and revision of sequence chromatograms. Each isolate was assigned an arbitrary sequence type (ST) number according to the allele profile.

Lineage assignment and phylogenetic analysis. Grouping of isolates into clonal complexes according to the number of single-locus and double-locus variants was done with the eBursts algorithm implemented in the START2 program (17). Split decomposition analysis was performed with Splitstree software for Windows (18).

A concatenated sequence constructed from the individual gene sequences (in the order of $\operatorname{arc} A, c y a A, f a d D, i c d A, l y s P, m t l D, r p o S$ ) was prepared for one representative strain of each ST. Concatenated se- quences were aligned and the phylogenetic tree was constructed using the neighbor-joining (NJ) method, with the distances estimated by the Kimura 2-parameter model and a bootstrapping of 1,000 replications using MEGA5 software.

PFGE. Genomic DNA preparation for pulsed-field gel electrophoresis (PFGE) analysis was carried out according to the procedure of PulseNet (19). DNA was digested with $30 \mathrm{U}$ XbaI (Fermentas, Thermo Fisher Scientific, Waltham, MA), and the fragments were resolved in a $1 \%$ Seakem Gold agarose gel (Lonza, Rockland, ME) in a contour-clamped homogeneous electric field (CHEF) DRIII apparatus (Bio-Rad, Hercules, CA) during $19 \mathrm{~h}$ with the following conditions: $14^{\circ} \mathrm{C}$, ramp of 2.2 to $54.2 \mathrm{~s}, 120^{\circ}$ angle, and voltage of $6 \mathrm{~V} / \mathrm{cm}$. Comparison of PFGE profiles was done with the GelCompar 6.1 software (Applied Maths, St. Martens Latem, Belgium). Similarities were obtained using the Dice coefficient at $0.5 \%$ optimization and $1.5 \%$ tolerance, and a dendrogram was constructed with the unweighted-pair group method using average linkages (UPGMA) clustering method.

\section{RESULTS}

EPEC isolation and identification. A total of 62 suspected isolates were obtained from 55 of the 388 bulk tank milk samples (14.17\%). All of the isolates were considered atypical EPEC, carrying the eae gene without amplifying any of the additional target genes $\left(s t x_{1}, s t x_{2}\right.$, and $b f p A)$ or pEAF. Ten more isolates were recovered from the environmental samples taken from 5 out of 10 farms (50\%): five isolates were obtained from water trough samples taken from four different farms, four isolates were from feces from four different farms, and one isolate was obtained from an air sample; moreover, 9 atypical EPEC isolates were confirmed from human stools.

Multilocus sequence typing and phylogenetic analysis. Sequences of seven housekeeping genes were obtained from all 81 isolates, and 19 ST were detected (Table 2); none of them were previously reported for atypical EPEC in studies carried out with the same genes $(6,20)$. The most frequent ST was ST 14, including 41 isolates, all of them obtained from milk and clinical samples. The allele frequency of the housekeeping genes ranged from 6 to 12 alleles per locus, with the most variable being loci $i c d A$ and $m l t D$ with 12 alleles each. Ten new alleles were detected in five different genes (Table 2). 
TABLE 2 Allele profile and relative frequency of ST detected after MLST analysis of 81 EPEC isolates

\begin{tabular}{|c|c|c|c|c|c|c|c|c|c|}
\hline \multirow[b]{2}{*}{ ST } & \multicolumn{7}{|c|}{ Allele no. of: } & \multirow{2}{*}{$\begin{array}{l}\text { Relative } \\
\text { frequency }\end{array}$} & \multirow[b]{2}{*}{ Origin of isolates } \\
\hline & $\operatorname{arcA}$ & cyaA & fadD & $i c d A$ & lys $P$ & $m t l D$ & rpos & & \\
\hline 1 & 2 & $36^{a}$ & 115 & 8 & 17 & $45^{a}$ & $71^{a}$ & 1 & Clinical \\
\hline 2 & 3 & 2 & 13 & 4 & 1 & 13 & 1 & 1 & Milk \\
\hline 3 & 3 & 3 & 2 & 2 & 1 & 3 & 1 & 1 & Clinical \\
\hline 4 & 3 & 3 & 2 & 2 & 1 & 4 & 1 & 6 & Milk and water \\
\hline 5 & 3 & 3 & 13 & 4 & 1 & 13 & 1 & 1 & Milk \\
\hline 6 & 3 & 3 & 13 & 39 & 1 & 13 & 17 & 1 & Feces \\
\hline 7 & 3 & 3 & 13 & $203^{a}$ & 1 & 13 & $69^{a}$ & 2 & Milk and water \\
\hline 8 & 3 & 3 & 20 & 23 & 1 & 31 & 1 & 8 & Milk \\
\hline 9 & 3 & 3 & 20 & 23 & 1 & 31 & $70^{a}$ & 1 & Water \\
\hline 10 & 3 & 3 & 49 & 4 & 1 & 13 & 1 & 1 & Milk \\
\hline 11 & 3 & 11 & 13 & 39 & 1 & $43^{a}$ & 1 & 3 & Milk and water \\
\hline 12 & 6 & 1 & 4 & 3 & 2 & 11 & 8 & 1 & Milk \\
\hline 13 & 7 & 26 & 13 & 54 & 35 & 34 & 46 & 1 & Milk \\
\hline 14 & 8 & 2 & 1 & 15 & 1 & 2 & 1 & 41 & Milk and clinical \\
\hline 15 & 8 & 3 & 2 & 4 & 1 & 13 & 1 & 4 & Milk, air, and feces \\
\hline 16 & 9 & 2 & 1 & 1 & 1 & 41 & 1 & 3 & Milk and clinical \\
\hline 17 & 9 & 3 & 2 & 4 & 1 & 13 & 1 & 3 & Feces and clinical \\
\hline 18 & 24 & 32 & 6 & 75 & 4 & 42 & 26 & 1 & Milk \\
\hline 19 & $27^{a}$ & $35^{a}$ & 110 & 136 & 78 & $44^{a}$ & 17 & 1 & Water \\
\hline
\end{tabular}

Three clonal complexes were revealed by eBurst analysis, grouping 7,2, and 2 ST, respectively. Clonal group 1 was centered on ST 5, with ST 2 and ST 10 as a single-locus variant (SLV) and ST 6 , ST 7, ST 15, and ST 17 as a double-locus variant (DLV). Clonal group 2 contained ST 3 and ST4, whereas clonal group 3 included ST 8 and ST 9. The remaining 8 ST were considered singletons, including the most frequent ST, ST 14. A SplitsTree graph (Fig. 1) shows the relative distances between STs.

Phylogenetic analysis of the supergene is shown in Fig. 2, showing a clustering of STs similar to that obtained with SplitsTree, with high bootstrapping values.

Some STs grouped together isolates from different origins, as

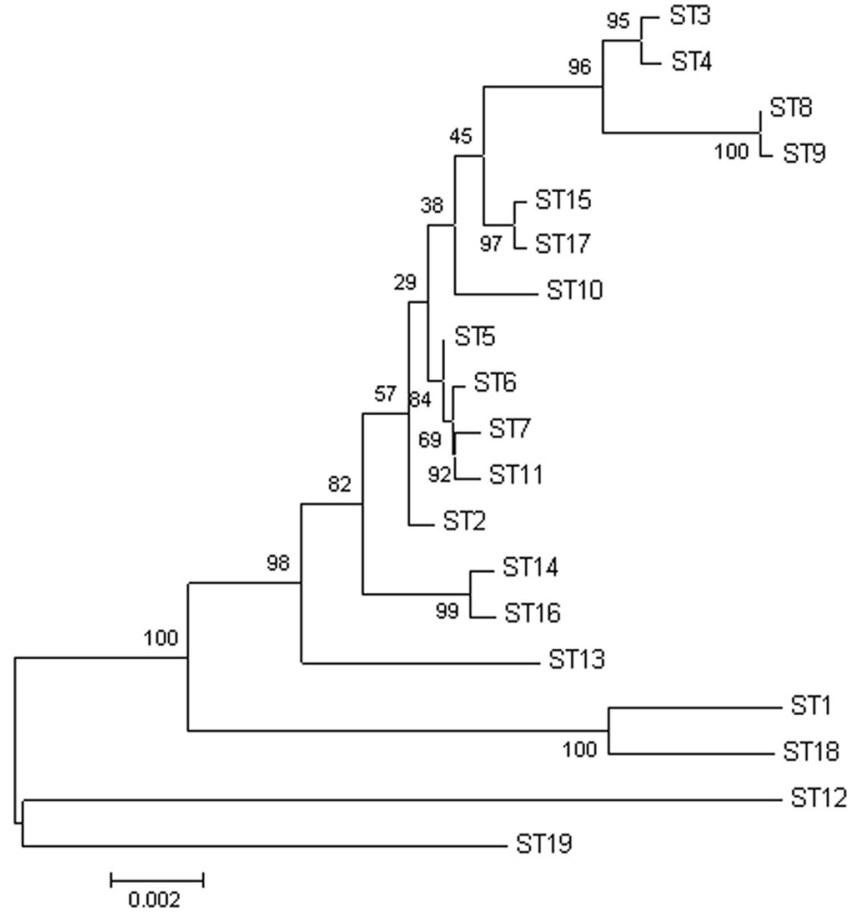

FIG 2 Neighbor-joining tree obtained from the phylogenetic analysis of the combined nucleotide sequences of the seven housekeeping genes in representatives from each ST. Bootstrapping values are shown in branch nodes.

in ST 4, which grouped five isolates obtained from milk produced on five farms with a water strain isolated from a different farm. ST 7 included water and milk samples isolated from different locations, ST 11 was composed of one water and two milk isolates, ST

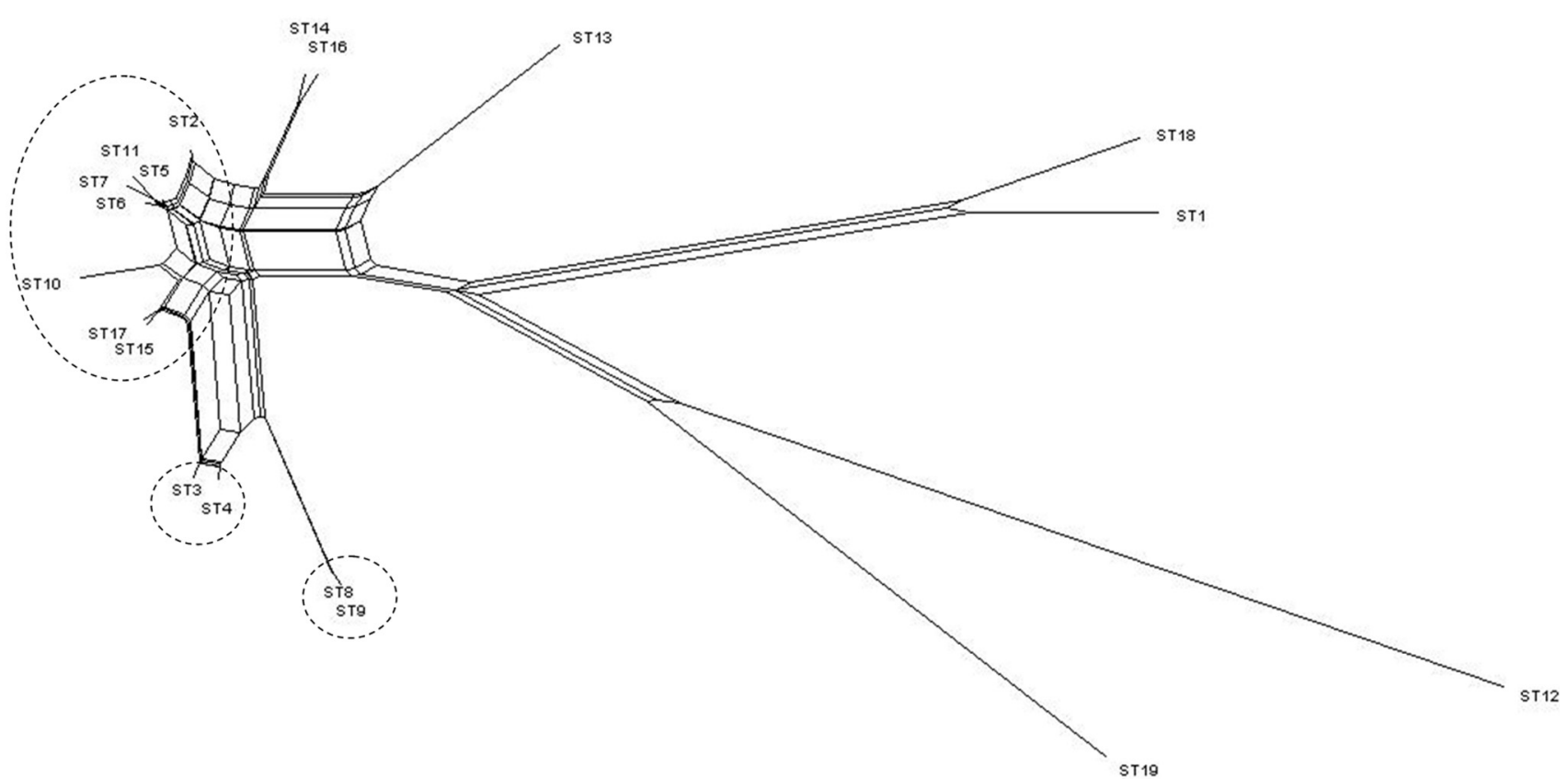

FIG 1 Phylogenetic splits network obtained after allele profile analysis with eBURST algorithm. Clonal complexes are indicated by broken lines. 
15 included two isolates from milk, one from air, and one from animal feces samples taken in different farms, ST 16 was composed of two clinical and one milk isolate, and ST 17 included two isolates from animal feces and one clinical isolate. An interesting finding was the absence of environmental isolates from ST 14 (Table 3).

Pulsed-field gel electrophoresis. PFGE typing of 81 isolates resulted in 57 patterns, which grouped in 24 clusters with a minimum cutoff value of $74.5 \%$ (Fig. 3). Identical profiles were detected in isolates from milk (34 strains in pulsotypes I, IV, X, XII, $\mathrm{XIV}$, and XIX) and clinical samples (2 strains in pulsotype XVI) and between one isolate from milk and one isolate from air (pulsotype VII). All of the isolates with indistinguishable PFGE profiles belong to the same ST. Nine clusters grouped isolates from different origins: milk and water (I, IV, XVII, and XVIII), milk and ovine feces (V), milk, air and ovine feces (VII), clinical samples and ovine feces (IX), and milk and clinical samples (VI and XV).

Table 3 summarizes the features of the 81 strains investigated in this study.

\section{DISCUSSION}

Humans have long been considered the main reservoir of EPEC (3), but this assumption is being revised in light of the characteristics of atypical EPEC strains, which are regularly found in animals $(2,5)$. The increasing isolation of atypical EPEC strains from foods of animal origin $(10,12,14,21)$ suggests that different animal species act as reservoirs for these microorganisms and represent a source of infections for humans, as already proposed by other authors $(6,8)$.

In this study, bulk tank sheep milk tested positive for $14.17 \%$ of the samples, and atypical EPEC strains were also isolated from the environment of the farm and from feces of the animals. A high degree of phylogenetic heterogeneity was observed among the strains, which form 19 sequence types and 24 pulsotypes. The genetic diversity in atypical EPEC appears to be a common trait, as already reported (22). In spite of the heterogeneity, comparison of the strains isolated from milk and farm environments to isolates obtained from human patients showed a clear relationship between milk and human isolates; thus, the main ST (ST 14) was composed of strains of those origins. This relationship was demonstrated by PFGE typing as well (clusters VI and XV) (Fig. 3). Another interesting finding of this study is the similarities observed between water and milk isolates, which grouped together in two ST and four PFGE clusters (Fig. 3).

The results obtained in this study do not clarify the routes of transmission of EPEC but indicate that strains that appear in milk are similar to strains causing disease in humans. Why the milk became contaminated remains unresolved, but similarities between milk and water isolates suggest a way of transmission through water used in the production of milk, either for drinking or for cleaning equipment. Robins-Browne et al. (23) showed that atypical EPEC strains are an important cause of human gastroenteritis acquired through water consumption, and García-Díez et al. (10) reported that molecular characteristics found in atypical EPEC isolates from samples of surface water were similar to those detected in human samples. These pieces of evidence, together with the findings of this study, suggest a possible route of human infection.

In conclusion, this study shows that ewes' milk carries strains
TABLE 3 Genotypic characteristics and origin (farm registration number and type of sample) of 81 EPEC isolates studied

\begin{tabular}{|c|c|c|c|c|}
\hline Strain & PFGE type & ST & Farm no. & Type of sample \\
\hline$\overline{\mathrm{M} 271 \mathrm{VO}}$ & 1 & 4 & 158 & Milk \\
\hline $\mathrm{M} 277 \mathrm{aVO}$ & 1 & 4 & 160 & Milk \\
\hline M277bVO & 1 & 4 & 160 & Milk \\
\hline M289VO & 1 & 4 & 167 & Milk \\
\hline F15VO & 1 & 4 & 187 & Water \\
\hline M387VO & 1 & 4 & 234 & Milk \\
\hline C156VO & 2 & 3 & & Clinical \\
\hline C289VO & 3 & 16 & & Clinical \\
\hline M39VO & 4 & 8 & 31 & Milk \\
\hline M77VO & 4 & 8 & 87 & Milk \\
\hline $\mathrm{M} 312 \mathrm{VO}$ & 4 & 8 & 179 & Milk \\
\hline M367VO & 4 & 8 & 210 & Milk \\
\hline M370VO & 4 & 8 & 213 & Milk \\
\hline M434VO & 4 & 8 & 275 & Milk \\
\hline M443VO & 4 & 8 & 287 & Milk \\
\hline M523VO & 4 & 8 & 361 & Milk \\
\hline $\mathrm{F} 12 \mathrm{VO}$ & 4 & 9 & 42 & Water \\
\hline F23VO & 5 & 6 & 66 & Feces \\
\hline M407VO & 5 & 15 & 243 & Milk \\
\hline F20VO & 6 & 15 & 64 & Air \\
\hline M313VO & 6 & 15 & 179 & Milk \\
\hline F16VO & 6 & 15 & 187 & Feces \\
\hline M278VO & 6 & 16 & 160 & Milk \\
\hline C294VO & 6 & 16 & & Clinical \\
\hline $\mathrm{F} 21 \mathrm{VO}$ & 8 & 17 & 64 & Feces \\
\hline F14VO & 9 & 17 & 157 & Feces \\
\hline $\mathrm{C} 322 \mathrm{VO}$ & 9 & 17 & & Clinical \\
\hline M361VO & 10 & 14 & 207 & Milk \\
\hline M385VO & 10 & 14 & 233 & Milk \\
\hline M337VO & 11 & 14 & 189 & Milk \\
\hline M229VO & 12 & 14 & 77 & Milk \\
\hline $\mathrm{M} 232 \mathrm{VO}$ & 12 & 14 & 91 & Milk \\
\hline M251VO & 12 & 14 & 106 & Milk \\
\hline M124VO & 12 & 14 & 223 & Milk \\
\hline M138VO & 12 & 14 & 261 & Milk \\
\hline M142VO & 12 & 14 & 314 & Milk \\
\hline M487VO & 12 & 14 & 336 & Milk \\
\hline M176VO & 12 & 14 & 375 & Milk \\
\hline M330VO & 13 & 14 & 185 & Milk \\
\hline M341VO & 13 & 14 & 191 & Milk \\
\hline M42VO & 14 & 14 & 32 & Milk \\
\hline M51VO & 14 & 14 & 58 & Milk \\
\hline M54VO & 14 & 14 & 59 & Milk \\
\hline M59VO & 14 & 14 & 61 & Milk \\
\hline M78VO & 14 & 14 & 87 & Milk \\
\hline $\mathrm{M} 242 \mathrm{VO}$ & 14 & 14 & 98 & Milk \\
\hline M247VO & 14 & 14 & 103 & Milk \\
\hline M82VO & 14 & 14 & 114 & Milk \\
\hline M90VO & 14 & 14 & 120 & Milk \\
\hline M92VO & 14 & 14 & 125 & Milk \\
\hline M93VO & 14 & 14 & 125 & Milk \\
\hline M100VO & 14 & 14 & 127 & Milk \\
\hline M99VO & 14 & 14 & 127 & Milk \\
\hline M105VO & 14 & 14 & 145 & Milk \\
\hline M106VO & 14 & 14 & 148 & Milk \\
\hline M108VO & 14 & 14 & 151 & Milk \\
\hline M110VO & 14 & 14 & 156 & Milk \\
\hline M111VO & 14 & 14 & 157 & Milk \\
\hline M126VO & 14 & 14 & 223 & Milk \\
\hline M130VO & 14 & 14 & 224 & Milk \\
\hline M186VO & 14 & 14 & 381 & Milk \\
\hline M187VO & 14 & 14 & 382 & Milk \\
\hline M344VO & 15 & 12 & 193 & Milk \\
\hline $\mathrm{C} 147 \mathrm{VO}$ & 15 & 14 & & Clinical \\
\hline C171VO & 16 & 14 & & Clinical \\
\hline C198VO & 16 & 14 & & Clinical \\
\hline $\mathrm{C} 212 \mathrm{VO}$ & 16 & 14 & & Clinical \\
\hline $\mathrm{F} 22 \mathrm{VO}$ & 17 & 11 & 66 & Water \\
\hline M448aVO & 17 & 11 & 296 & Milk \\
\hline M532VO & 17 & 11 & 388 & Milk \\
\hline F17VO & 18 & 7 & 42 & Water \\
\hline M102VO & 18 & 7 & 133 & Milk \\
\hline M508VO & 19 & 14 & 354 & Milk \\
\hline M151VO & 19 & 14 & 364 & Milk \\
\hline M254aVO & 20 & 2 & 107 & Milk \\
\hline M29aVO & 20 & 5 & 24 & Milk \\
\hline M442aVO & 20 & 10 & 286 & Milk \\
\hline M36VO & 21 & 18 & 29 & Milk \\
\hline M438aVO & 22 & 13 & 281 & Milk \\
\hline F13VO & 23 & 19 & 157 & Water \\
\hline $\mathrm{C} 22 \mathrm{VO}$ & 24 & 1 & & Clinical \\
\hline
\end{tabular}




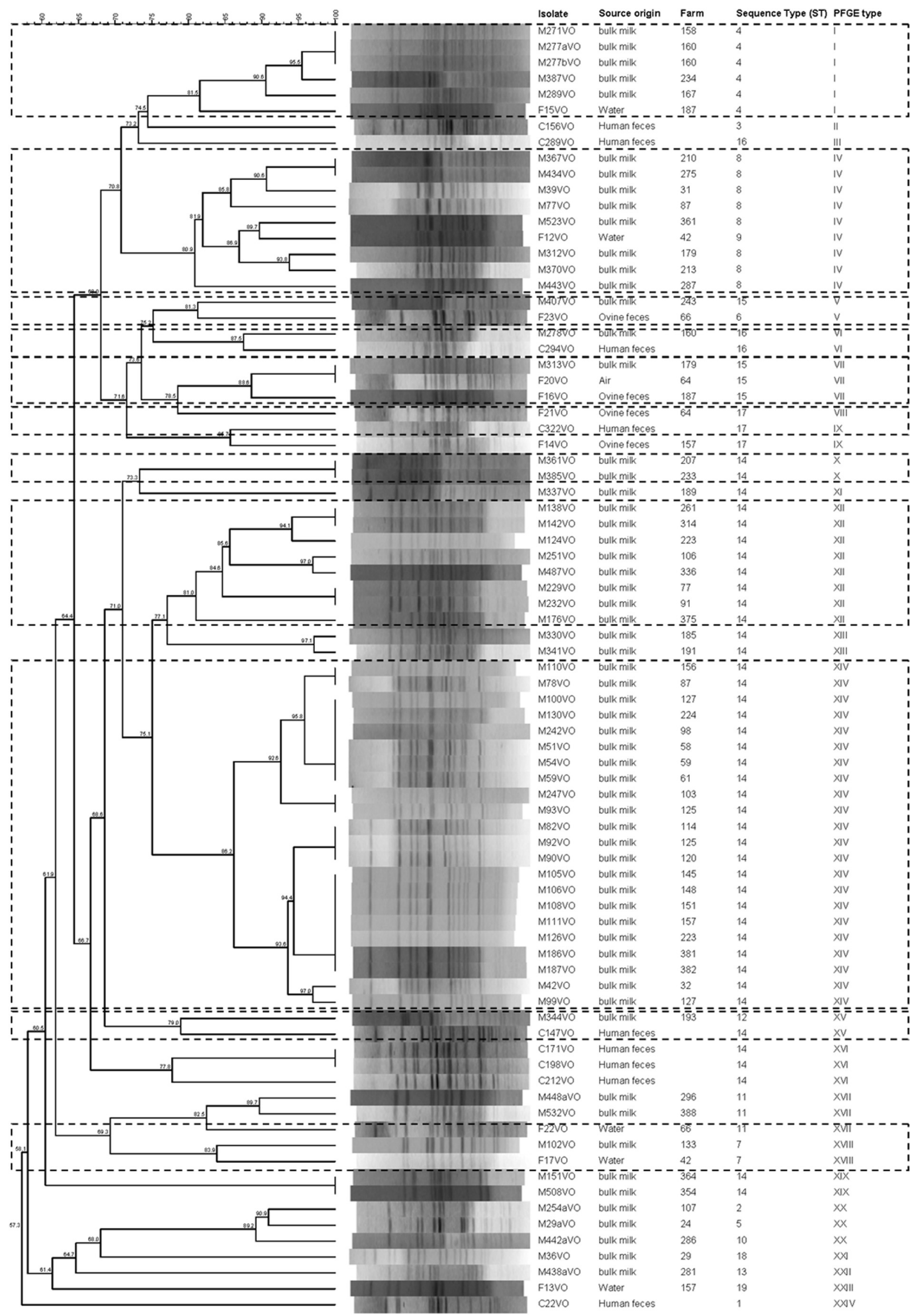

FIG 3 PFGE profiles of 81 atypical EPEC isolates obtained from ewes' milk, farm environment, and clinical samples. The corresponding sequence types (ST) are also listed. Main groups are marked by broken lines. 
of atypical EPEC related to those found in human samples and suggests possible transmission routes for this emerging pathogen.

\section{ACKNOWLEDGMENTS}

This work was financed by project AGL2011-26118/ALI of the Spanish R\&D program (Ministry of Economy and Competitiveness) and Junta de Castilla y León (Ayuda Grupo de Excelencia GR155). Verónica Otero was supported by a grant from the FPU program of the Spanish government.

We are grateful for the valuable assistance of Silvia Herrera-León and Sergio Sánchez from the Bacteriology Department of the National Microbiology Centre of the Instituto de Salud Carlos III and María Antonia Remacha from the Microbiology Service of the University Hospital of León.

\section{REFERENCES}

1. Chen DH, Frankel G. 2005. Enteropathogenic Escherichia coli: unravelling pathogenesis. FEMS Microbiol. Rev. 29:83-98.

2. Trabulsi LR, Keller R, Gomes T. 2002. Typical and atypical enteropathogenic Escherichia coli. Emerg. Infect. Dis. 8:508-513.

3. Nataro JP, Kaper JB. 1998. Diarrheagenic Escherichia coli. Clin. Microbiol. Rev. 11:142-201.

4. Kaper JB, Nataro JP, Mobley HLT. 2004. Pathogenic Escherichia coli. Nat. Rev. Microbiol. 2:123-140.

5. Hernandes RT, Elias WP, Vieira M, Gomes T. 2009. An overview of atypical enteropathogenic Escherichia coli. FEMS Microbiol. Lett. 297: 137-149.

6. Moura RA, Sircili MP, Leomil L, Matté MHT, Elias LRWP, Irino K, Pestana de Castro AF. 2009. Clonal relationship among atypical enteropathogenic Escherichia coli strains isolated from different animal species and humans. Appl. Environ. Microbiol. 75:7399-7408.

7. Cortés C, De la Fuente R, Blanco J, Blanco M, Blanco JE, Dhabi G, Mora A, Justel P, Contreras A, Sanchez A. 2005. Serotypes, virulence genes and intimin types of verotoxin-producing Escherichia coli and enteropathogenic E. coli isolated from healthy dairy goats in Spain. Vet. Microbiol. 110:67-76.

8. Blanco M, Schumacher S, Tasara T, Zweifel C, Blanco J, Dahbi G, Blanco J, Stephan R. 2005. Serotypes, intimin variants and other virulence factors of eae positive Escherichia coli strains isolated from healthy cattle in Switzerland. Identification of a new intimin variant gene (eaeๆ2). BMC Microbiol. 5:23. doi:10.1186/1471-2180-5-23.

9. Faroog S, Hussain I, Mir MA, Bhat MA, Wani SA. 2009. Isolation of atypical enteropathogenic Escherichia coli and Shiga toxin 1 and $2 \mathrm{f}-$ producing Escherichia coli from avian species in India. Lett. Appl. Microbiol. 48:692-697.

10. García Díez M, Meindl K, Frässdorf J, Wolf S, Schalch B, Busch U. 2009. Prevalence of enteropathogenic Escherichia coli in food and water in Bavaria in 2007. Arch. Lebensmittelhyg. 60:77-81.

11. Altalhi AD, Hassan SA. 2009. Bacterial quality of raw milk investigated by Escherichia coli and isolates analysis for specific virulence-gene markers. Food Control 20:913-917.

12. Holko I, Bisova T, Holkova Z, Kmet V. 2006. Virulence markers of Escherichia coli strains isolated from traditional cheeses made from unpasteurised sheep milk in Slovakia. Food Control 17:393-396.

13. Carneiro LAM, Lins MC, Garcia FRA, Silva APS, Mauller PM, Alves GB, Rosa ACP, Andrade JRC, Freitas-Almeida AC, Queiroz MLP. 2006.
Phenotypic and genotypic characterisation of Escherichia coli strains serogrouped as enteropathogenic E. coli (EPEC) isolated from pasteurised milk. Int. J. Food Microbiol. 108:15-21.

14. da Silva ZN, Cunha AS, Lins MC, Carneiro LAM, Almeida ACF, Queiroz MLP. 2001. Isolation and serological identification of enteropathogenic Escherichia coli in pasteurized milk in Brazil. Rev. Saúde Pública 35:375-379.

15. Son I, Van Kessel JA, Karns JS. 2009. Genotypic diversity of Escherichia coli in a dairy farm. Foodborne Pathog. Dis. 6:837-847.

16. Tamura K, Peterson D, Peterson N, Stecher G, Nei M, Kumar S. 2011. MEGA5: molecular evolutionary genetics analysis using maximum likelihood, evolutionary distance, and maximum parsimony methods. Mol. Biol. Evol. 28:2731-2739.

17. Jolley KA, Feil EJ, Chan MS, Maiden MC.2001. Sequence type analysis and recombinational tests (START). Bioinformatics 17:1230-1231.

18. Huson DH, Bryant D. 2006. Application of phylogenetic networks in evolutionary studies. Mol. Biol. Evol. 23:254-267.

19. Ribot EM, Fair MA, Gautom R, Cameron DN, Hunter SB, Swaminathan B, Barrett TJ. 2006. Standardization of pulsed-field gel electrophoresis protocols for the subtyping of Escherichia coli O157:H7, Salmonella, and Shigella for PulseNet. Foodborne Pathog. Dis. 3:59-67.

20. Leomil L, Pestana de Castro AF, Krause G, Schmidt H, Beutin L. 2005. Characterization of two major groups of diarrheagenic Escherichia coli O26 strains which are globally spread in human patients and domestic animals of different species. FEMS Microbiol. Lett. 249:335-342.

21. Bandyopadhyay S, Lodh C, Rahaman H, Bhattacharya D, Bera AK, Ahmed FA, Mahanti A, Samanta I, Mondal DK, Bandyopadhyay S, Sarkar S, Dutta TK, Maity S, Paul V, Ghosh MK, Sarkar M, Baruah KK. 2012. Characterization of Shiga toxin producing (STEC) and enteropathogenic Escherichia coli (EPEC) in raw yak (Poephagus grunniens) milk and milk products. Res. Vet. Sci. 93:604-610.

22. Afset JE, Anderssen E, Bruant G, Harel J, Wieler L, Bergh K. 2008. Phylogenetic backgrounds and virulence profiles of atypical enteropathogenic Escherichia coli strains from a case-control study using multilocus sequence typing and DNA microarray analysis. J. Clin. Microbiol. 46: $2280-2290$.

23. Robins-Browne RM, Bordun AM, Tauschek M, Bennett-Wood VR, Russell J, Oppedisano F, Lister NA, Bettelheim KA, Fairley CK, Sinclair MI, Hellard ME. 2004. Escherichia coli and community-acquired gastroenteritis, Melbourne, Australia. Emerg. Infect. Dis. 10:1797-1805.

24. Paton AW, Paton JC. 1998. Detection and characterization of Shiga toxigenic Escherichia coli by using multiplex PCR assays for $s t x_{1}, s t x_{2}, e a e A$, enterohemorrhagic E. coli $h l y A, r f b_{\mathrm{O} 111}$, and $r f b_{\mathrm{O} 157}$. J. Clin. Microbiol. 36:598-602.

25. Oswald E, Schmidt H, Morabito S, Karch H, Marches O, Caprioli A. 2000. Typing of intimin genes in human and animal enterohemorrhagic and enteropathogenic Escherichia coli: characterization of a new intimin variant. Infect. Immun. 68:64-71.

26. Franke J, Franke S, Schmidt H, Schwarzkopf A, Wieler LH, Baljer G, Beutin L, Karch H. 1994. Nucleotide sequence analysis of enteropathogenic Escherichia coli (EPEC) adherence factor probe and development of PCR for rapid detection of EPEC harboring virulence plasmids. J. Clin. Microbiol. 32:2460-2463.

27. Gunzburg ST, Tornieporth NG, Riley LW. 1995. Identification of enteropathogenic Escherichia coli by PCR-based detection of the bundleforming pilus gene. J. Clin. Microbiol. 33:1375-1377. 


\title{
Evaluation of two antimicrobial packaging films against Escherichia coli 0157:H7 strains in vitro and during storage of a Spanish ripened sheep cheese (Zamorano)
}

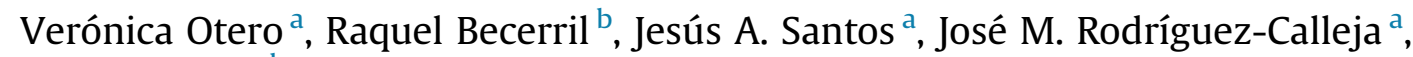 \\ Cristina Nerín ${ }^{\mathrm{b}}$, María-Luisa García-López ${ }^{\mathrm{a}, *}$ \\ ${ }^{a}$ Department of Food Hygiene and Food Technology, Veterinary Faculty, University of León, E-24071 León, Spain \\ ${ }^{\mathrm{b}}$ Department of Analytical Chemistry I3A, University of Zaragoza, Campus Rio Ebro, Maria de Luna 3, 50018 Zaragoza, Spain
}

\section{A R T I C L E I N F O}

\section{Article history:}

Received 5 September 2013

Received in revised form

4 February 2014

Accepted 11 February 2014

Available online 22 February 2014

\section{Keywords:}

Antimicrobial active food packaging

E. coli 0157:H7

Sheep cheese

Oregano essential oil

Ethyl lauroyl arginate

LAE

\begin{abstract}
A B S T R A C T
The antimicrobial activity of two packaging films (polypropylene - PP- and polyethylene terephthalate PET-) coated with different concentrations (0, 4, 6 and 8\%) of essential oil from Origanum vulgare (OR) and Ethyl Lauroyl Arginate $\mathrm{HCl}$ (LAE) was tested against two Escherichia coli $\mathrm{O} 157: \mathrm{H} 7$ strains using in vitro systems and a raw milk sheep cheese model (Zamorano). The influence of the antimicrobials on the sensory attributes of cheese was also evaluated. For both strains, the MBC (minimum bactericidal concentration) values were identical to their respective MIC (minimum inhibitory concentration) values and lower for LAE (25 mg/l) than for OR (200-400 mg/l). PP and PET films coated with OR were tested by a vapour phase assay and the Japanese Standard method (JIS Z 2801:2000). Both films coated with LAE were tested by an agar diffusion method. Overall, in vitro tests were effective against both strains. The inhibitory activity depended on the active compound concentration, the target strain and the packaging material, PET being more effective than PP. For inoculated cheese slices, OR and LAE PP films did not effectively decrease $E$. coli $0157: H 7$ counts after 7-days cold storage. PET films incorporating 6 and $8 \%$ of OR and LAE significantly $(p<0.05)$ decreased the numbers of both strains and also did $4 \%$ for the reference and wild strain depending on the antimicrobial. LAE PP, OR PET and LAE PET did not significantly $(p>0.05)$ affect sensorial characteristics of Zamorano cheese. Packaging with PET films coated with $\geq 6 \%$ LAE concentrations might be useful in reducing E. coli 0157:H7 numbers in sheep cheese.
\end{abstract}

(c) 2014 Elsevier Ltd. All rights reserved.

\section{Introduction}

Pathogenic Escherichia coli strains are categorised into six specific groups or pathotypes based on their virulence determinants. One of them is enterohaemorragic E. coli (EHEC), which is considered a subset of Shiga-toxin producing $E$. coli (STEC) also named verocytotoxic-producing E. coli (VTEC) (Nataro \& Kaper, 1998). Although several STEC serotypes can cause serious human illness and are recognised as EHEC, serotype 0157:H7 is an important food borne pathogen and the predominant cause of EHEC-associated disease worldwide. In humans, low numbers (10-100 cells) of serotype 0157:H7 strains can cause severe illnesses such as diarrhoea and haemorrhagic colitis (HC) that may progress into a life-

\footnotetext{
* Corresponding author. Departamento de Higiene y Tecnología de los Alimentos, Facultad de Veterinaria, Universidad de León, E-24071 León, Spain. Tel.: +34 987 291 119; fax: +34 987291284.

E-mail address: mlgarl@unileon.es (M.-L. García-López).
}

threatening sequel called haemolytic uremic syndrome (HUS), especially in young children and the elderly. HUS is the most common cause of acute renal failure in young children and an important cause of morbidity and mortality in the elderly (Meng, Lejeune, Zhao, \& Doyle, 2013).

The main reservoir of this pathogen appears to be wild and domestic ruminants such as deer, cattle, goats and sheep (Ferens \& Hovde, 2011). In addition to undercooked beef hamburgers and other meat products, as well as water, fruits and vegetables, cheeses made from raw milk have been implicated in infections of $E$. coli 0157:H7 (Espié et al., 2006; Farrokh et al., 2013). The occurrence of EHEC strains in sheep cheeses and raw sheep milk dedicated to cheesemaking has been reported by a number of authors in Spain and also in other countries (Caro \& García-Armesto, 2007; Caro, Mateo, Rúa, \& García-Armesto, 2011; Farrokh et al., 2013; Rey et al., 2006). Ewes' breeding is an important activity in Spain (ca. 22\% of the EU), which is concentrated particularly in the inner regions. According to the Spanish Ministry of Agriculture, Food and Environment (http:// 
www.magrama.gob.es; last accessed 30 July 2013), the Castilla y León region is the first producer of ewes' milk, with more than $50 \%$ of the Spanish production, most of this production being dedicated to manufacturing of raw sheep milk cheeses such as Zamorano cheese.

Active packaging has been defined as packaging which performs some desired functions other than merely providing a barrier to the external environment (Rooney, 2005). According to Commission Regulation (EC) No 450/2009 (European Commission, 2009), "active materials and articles means materials and articles that are intended to extend the shelf-life or to maintain or improve the condition of packaged food; they are designed to deliberately incorporate components that would release or absorb substances into or from the packaged food or the environment surrounding the food".

Antimicrobial packaging is a form of active food packaging which is beneficial to the consumers as well as to the food industry since it can extend product shelf-life and/or maintain food safety by killing or reducing the growth rate of target microorganisms. Several antimicrobial agents could be incorporated into conventional food packaging systems (Cha \& Chinnan, 2004; López, Sánchez, Batlle, \& Nerín, 2007a; Nerin, 2012; Suppakul, Miltz, Sonneveld, \& Bigger, 2003) including chemical agents, natural agents and probiotics (Han, 2005). A number of these compounds has been proposed and tested for antimicrobial activity in food packaging including oregano essential oil (OR) and Ethyl Lauroyl Arginate $\mathrm{HCl}$ (LAE). Antimicrobial films with OR and LAE have been tested against some Salmonella serovars, Listeria monocytogenes and sometimes against a non pathogenic E. coli strain in an infant milk formula (MurielGalet, López-Carballo, Gavara, \& Hernández-Muñoz, 2012b), packaged salads (Muriel-Galet, Cerisuelo, López-Carballo, Lara, Gavara, \& Hernández-Muñoz, 2012a) and cooked sliced ham (Theinsathid, Visessanguan, Kruenate, Kingcha, \& Keeratipibul, 2012). However, information on the effect of packaging films coated with OR or LAE on the behaviour of strains belonging to the pathogenic serotype E. coli $\mathrm{O} 157: \mathrm{H7}$ is not available.

This study was undertaken to evaluate the anti-E. coli O157:H7 activity of two packaging films coated with different concentrations of OR and LAE. The activity was studied by in vitro tests and also by direct contact with artificially contaminated samples of a Spanish ripened sheep cheese (Zamorano cheese). The effects of the antimicrobials on the sensory attributes of cheese were also studied.

\section{Materials and methods}

\subsection{Bacterial strains}

Two strains of E. coli 0157:H7 were used: non pathogenic strain CECT (Spanish Type Culture Collection) 5947 and strain M364VO isolated by us from a tank of sheep milk in a farm in Castilla y León (Spain). The latter strain carried the $s t x 2$ and eae genes.

Both strains were stored at $-18{ }^{\circ} \mathrm{C}$ in Nutrient Broth (NB, Scharlab, Barcelona, Spain) with 40\% Glycerol. Subcultures were grown overnight in Tryptone Soya Broth (TSB, Scharlab) at $37^{\circ} \mathrm{C}$.

\subsection{Antimicrobial compounds}

Oregano essential oil obtained from Origanum vulgare L (OR; Chemical Abstracts Service (CAS) Registry Number 8007-11-2), supplied by Argolide Química SL. (Barcelona, Spain), and Ethyl Lauroyl Arginate $\mathrm{HCl}$ (LAE; CAS Registry Number 60372-77-2), supplied by Lamirsa (Barcelona, Spain), were used.

\subsection{Active films}

The coating technology used to produce the active materials was a process protected by the European Patent EP1657181 (Nerin \&
Garcés, 2006). The active films were manufactured and supplied by the Spanish company ARTIBAL S.A. (Sabiñánigo, Spain). They consisted of coating layers with known concentrations of OR (4, 6 and $8 \%$ ) and LAE (4, 6 and 8\%). The plastic film PET (polyethylene terephthalate) was $23 \mu \mathrm{m}$ thick with a density of $18.73 \pm 0.02 \mathrm{~g} / \mathrm{m}^{2}$. The PP (polypropylene) film was $40 \mu \mathrm{m}$ thick. The active films contained the antimicrobial compounds expressed as a percentage of weight active agent/weight wet active layer. ATOX (active coating) and ACRIL (acrylic antimicrobial coating) are the industrial denominations of varnishes. The gramage of the coating was in all cases $4 \mathrm{~g} / \mathrm{m}^{2}$.

\subsection{Antimicrobial susceptibility assays}

\subsubsection{Broth dilution assays}

A broth dilution assay was used to determine the minimum inhibitory concentration (MIC) and the minimum bactericidal concentration (MBC) for both OR and LAE (Becerril, Gomez-Lus, Goni, Lopez, \& Nerin, 2007).

2.4.1.1. OR. Serial two-fold dilutions, between 2.5 and $160 \mathrm{mg} / \mathrm{ml}$, were made in dimethyl sulfoxide (DMSO) (Sigma-Aldrich Química, S.A., Madrid, Spain) (Sacchetti et al., 2005). Then, $10 \mu$ l aliquots were added to $890 \mu$ l of TSB (Scharlab) plus 0.6\% Yeast Extract (Scharlab) (TSBYE), and inoculated with $100 \mu$ of the bacterial suspensions (ca. $10^{6} \mathrm{cfu} / \mathrm{ml}$ ) in TSBYE. The OR final concentrations ranged from 0.025 to $1.6 \mathrm{mg} / \mathrm{ml}$. To determine whether DMSO would be inhibitory to the bacteria, controls with $10 \mu \mathrm{l}$ of the solvent instead of OR dilutions were performed for both strains. The cultures were incubated at $37^{\circ} \mathrm{C}$ for $24 \mathrm{~h}$ while shaking. The bacterial growth was determined by measuring the optical density at $625 \mathrm{~nm}$. Samples $(100 \mu \mathrm{l})$ were also taken and serial dilutions were plated on Tryptone Soya Agar (TSA, Scharlab) and incubated at $37^{\circ} \mathrm{C}$ for $24 \mathrm{~h}$.

2.4.1.2. LAE. Serial two-fold dilutions, between 1.25 and $160 \mathrm{mg} / \mathrm{ml}$ were made in sterile distilled water and tested as above (LAE final concentrations ranged from 0.0125 to $1.6 \mathrm{mg} / \mathrm{ml}$ ), cultures being incubated without shaking.

MIC was defined as the lowest concentration of antimicrobials at which bacterial growth was not detected. The MBC was the lowest concentration of antimicrobials at which bacteria failed to grow in TSBYE and were not cultured after plating onto TSA. Both were expressed as $\mathrm{mg}$ of antimicrobials per l. Tests were performed in triplicate.

\subsubsection{Vapour phase assay}

The vapour phase activity between OR incorporated in the packaging materials and both E. coli strains was tested. Tests were carried out in triplicate by inoculating TSA plates with $100 \mu \mathrm{l}$ of TSBYE containing $10^{6} \mathrm{cfu} / \mathrm{ml}$ of each organism. The Petri dish covers were replaced by the active films as described by López, Sánchez, Batlle, and Nerín (2007b) and the growth examined after incubation at $37{ }^{\circ} \mathrm{C}$ for $24 \mathrm{~h}$. Controls with PP and PET without active compounds were also tested. When the growth of the target strains covered by the active films was compared with that of the controls, the antimicrobial effect of the atmosphere derived from the different concentrations of $\mathrm{OR}$ was categorised as: -, no inhibition; +, partial inhibition and ++ , total inhibition.

\subsubsection{Direct contact assays}

2.4.3.1. OR. The Japanese Industrial Standard method JIS Z 2801:2000 (Anonymous, 2000) was used to evaluate the antibacterial activity of the active films by direct contact. Briefly, three pieces $(50 \times 50 \mathrm{~mm})$ of each test film coated with 4,6 and $8 \%$ of OR were placed, with the active surface up, on Petri dishes, inoculated 
with $400 \mu \mathrm{l}$ of bacterial suspensions $\left(\mathrm{ca} .10^{5} \mathrm{cfu} / \mathrm{ml}\right.$ ) and covered with $40 \times 40 \mathrm{~mm}$ pieces of uncoated sterile PP and PET films. Six untreated subsamples of each film (coated only with the varnish) were processed as above. Half of them were used for the determination of the initial cell count directly after inoculation. After incubation for $24 \mathrm{~h}$ at $37^{\circ} \mathrm{C}$, the bacteria were harvested from the films surfaces using $10 \mathrm{ml}$ of Buffered Peptone (Scharlab), which was serially diluted and plated on TSA. After $24 \mathrm{~h}$ at $37{ }^{\circ} \mathrm{C}$, the antimicrobial activity was expressed as the $R$ value. The $R$ value was calculated using the formula $R=\log (B / C)$ where, B: average of colony forming units (cfu) on the untreated films and $C$ : average of the cfu found on the treated ones.

2.4.3.2. LAE. Since the JIS method could not be used for LAE, the evaluation of the antibacterial activity of this compound by direct contact was carried out using samples of coated PP and PET films $(4,6$ and $8 \%$ of LAE) and an agar diffusion method as described by Iseppi et al. (2008). The varnish (ACRIL) coat weight was $4 \mathrm{~g} / \mathrm{m}^{2}$. The coated films $(40 \times 40 \mathrm{~mm})$ were placed onto TSA (Oxoid) plates seeded with $10^{8} \mathrm{cfu} / \mathrm{ml}$ from overnight TSBYE (Scharlab) cultures. The plates were incubated at $37{ }^{\circ} \mathrm{C}$ for $24 \mathrm{~h}$ and the antagonistic activity was quantified by a clear zone of inhibition in the indicator lawn around and in contact with the coated plastic film. Films coated with varnish not containing LAE were also tested as negative controls.

\subsection{Antimicrobial activity in Zamorano sheep cheese}

Because of the source of strain ECVT M364VO, wedges of commercial Spanish Zamorano cheese were used. Zamorano cheese is a hard cheese, made with the milk of the Churra and Castilian sheep breeds.

Commercial cheese wedges, prepared for an estimated domestic consumption of a week, were purchased and sliced. The slices were contaminated on the surface by dipping in a $10^{6} \mathrm{cfu} / \mathrm{ml}$ TSBYE broth to achieve final levels of $\mathrm{ca} .10^{4} \mathrm{cfu} / \mathrm{g}$. Control and contaminated cheese slices were placed between two pieces of PP or PET films coated with the varnish alone and three different concentrations of each antimicrobial $(4,6$, and $8 \%$ ). Slices were then placed in uncoated PP bags and stored at $3{ }^{\circ} \mathrm{C}$ to reflect domestic storage conditions. Numbers of the E. coli 0157:H7 strains were counted, just after inoculation, and after one and seven storage days on MacConkey Agar with Sorbitol (SMAC, Scharlab) after $24 \mathrm{~h}$ incubation at $37^{\circ} \mathrm{C}$. Each experiment was performed six times.

\subsection{Statistical analysis of data on Zamorano sheep cheese}

E. coli counts were transformed and expressed as log cfu/g. Basic descriptive statistics of each parameter (mean and standard deviation) were calculated and linear regression analysis was used to determine the relationship between parameters. The potential influence of strain, film, antimicrobial and storage day was analysed by using multi-factor analysis of variance (ANOVA). Subsequently, post-hoc pairwise comparisons were performed through the Fisher Least Significant Difference (Fisher-LSD) test. Data analysis was carried out with the "Statistica for Windows release 7.0" software (Statsoft Inc., Tulsa, OK, USA).

\subsection{Sensory analysis}

A panel of 10 members was recruited for evaluating the effect of the coated films on the smell and taste of non contaminated Zamorano cheese. All were selected on the basis of commitment and motivation. Panellists were asked to rank the samples in descending order based on overall acceptability. Control and wrapped cheese
Table 1

$\mathrm{MIC}^{\mathrm{a}}$ and $\mathrm{MBC}^{\mathrm{b}}$ values for two E. coli $\mathrm{O} 157: \mathrm{H} 7$ strains in broth dilution assays.

\begin{tabular}{llllll}
\hline Antimicrobial activity & $\mathrm{OR}^{\mathrm{c}}$ & & \multicolumn{2}{l}{ LAE $^{\mathrm{d}}$} & \\
\cline { 2 - 3 } \cline { 5 - 6 } & Strain & Strain & & Strain & Strain \\
& M364VO $^{\mathrm{e}}$ & CECT $^{\mathrm{f}} 5947$ & & M364VO & CECT 5947 \\
\hline $\operatorname{MIC}(\mathrm{mg} / \mathrm{l})$ & 400 & 200 & & 25 & 25 \\
$\operatorname{MBC}(\mathrm{mg} / \mathrm{l})$ & 400 & 200 & & 25 & 25 \\
\hline
\end{tabular}

\footnotetext{
${ }^{a}$ Minimum inhibitory concentration.

b Minimum bactericidal concentration.

Oregano essential oil obtained from Origanum vulgare.

d Ethyl Lauroyl Arginate $\mathrm{HCl}$.

e Strain from sheep milk.

${ }^{\mathrm{f}}$ CECT, Spanish Type Culture Collection.
}

samples (PP with 4, 6 and 8\% OR; PP with 4, 6 and 8\% LAE; PET with 4, 6 and $8 \%$ OR; and PET with 4, 6 and $8 \% \mathrm{LAE}$ ) were analysed after one and seven days of chilled storage in four different sampling days. Data were analysed and interpreted using the Friedman test according to ISO standard 8587:2006 (Anonymous, 2006, 2013).

\section{Results and discussion}

\subsection{Determination of MIC and MBC values against E. coli 0157:H7}

The MIC and MBC values of OR and LAE for both E. coli O157:H7 strains are given in Table 1 . MBC values of each compound were identical to their respective MICs. Similar data were reported by Becerril et al. (2007) for OR against the non-STEC strain E. coli ATCC 25922 (MIC and MBC values of $190 \mathrm{mg} / \mathrm{l}$ ). For one E. coli O157:H7 strain, the OR MIC and MBC values were $625 \mu \mathrm{l} / \mathrm{l}$ (Burt \& Reinders, 2003). In this study, LAE showed stronger antibacterial activity than $\mathrm{OR}$, the latter being two-fold more efficient against the reference culture than against the sheep milk strain. For LAE, the MIC and MBC values found by Muriel-Galet et al. (2012b) against the nonSTEC strain E. coli ATCC 25922 were 20 and 32 ppm, respectively.

The high antimicrobial activity of LAE on Gram-negative bacteria has been attributed to alterations which involve both the cytoplasm membrane and the external membrane without causing cellular lysis (Rodriguez, Seguer, Rocabayera, \& Manresa, 2004). Among a number of plant essential oils, essential oil from $O$. vulgare has been found to exhibit the strongest in vitro bacteriostatic and bactericidal activities against non-verotoxigenic and verotoxigenic E. coli 0157:H7 strains (Burt \& Reinders, 2003; Marino, Bersani, \& Comi, 2001).

\subsection{Vapour phase assay}

Table 2 shows the inhibitory effect of the atmosphere derived from OR incorporated in the packaging materials (PP and PET). Oregano essential oil did not inhibit the growth of both $E$. coli 0157:H7 strains under 4\%, but did under 6\% (partial inhibition) and $8 \%$ (partial or total inhibition). A number of studies (Becerril et al., 2007; Gutiérrez, Batlle, Sánchez, \& Nerín, 2010; López et al., 2007b; Rodriguez, Nerin, \& Batlle, 2008) has reported that, in the vapour phase assays, the antimicrobial activity of active packaging containing essential oils (EOs) is produced by the volatile compounds present in the headspace of the Petri dish and the amount of active compounds present in the agar. For oregano essential oil, these compounds have been mainly identified as the phenolic compounds carvacrol and thymol although minor components appear to play a significant role (Burt, 2004; Gutiérrez et al., 2010).

The effectiveness of EOs incorporated into packaging materials tested by vapour phase assay has been related to the concentration of the active compound, the packaging material and the target 
Table 2

Antimicrobial effect of the atmosphere derived from different concentrations of OR incorporated in two packaging films against two E. coli 0157:H7 strains.

\begin{tabular}{lll}
\hline Films & Strain M364VO & Strain CECT 5947 \\
\hline $0 \% \mathrm{OR}^{\mathrm{c}} \mathrm{PP}^{\mathrm{d}}$ & $-{ }^{\mathrm{e}}$ & - \\
$0 \% \mathrm{OR} \mathrm{PET}^{\mathrm{f}}$ & - & - \\
$4 \%$ OR PP & - & - \\
$4 \%$ OR PET & - & - \\
$6 \%$ OR PP & + & + \\
$6 \%$ OR PET & + & + \\
$8 \%$ OR PP & ++ & ++ \\
$8 \%$ OR PET & + & ++ \\
\hline${ }^{\text {a }}$ Strain from sheep milk. & \\
b CECT, Spanish Type Culture Collection. & \\
c Oregano essential oil obtained from Origanum vulgare. & \\
d PP, Polypropylene. & \\
e,- no inhibition; +, partial inhibition; ++, total inhibition. \\
f PET, Polyethylene terephthalate.
\end{tabular}

microorganism (Gutiérrez et al., 2010; López et al., 2007b; Rodriguez et al., 2008). In this study, higher concentrations of OR in the active coatings resulted in higher antimicrobial activity, 6\% OR being the minimum concentration showing inhibition against both E. coli $0157:$ H7 strains. At 8\% OR, differences were observed between PP and PET. Thus, total inhibition by $8 \%$ OR PP was observed against both E. coli 0157:H7 strains while 8\% OR PET completely inhibited only E. coli O157:H7 reference strain. Testing the behaviour of different films, Gutiérrez et al. (2010) concluded that a critical point in the design of an active packaging is the material used because not only the concentration of the active compound, but also the kinetic of release and the polymer play an important role since it is necessary to reach a minimum concentration of the active compounds in the solid medium during the lag phase of the microorganisms to inhibit their growth, and this occurs faster with certain active polymers. Overall, EOs are more effective against moulds and yeasts than against bacteria and among the latter, they appear to be more efficient against Gram- positive species (Burt, 2004). In addition, it has been reported that target microorganisms have a clear influence on the composition of the atmospheres generated by EOs. This finding has been attributed to diverse interactions and/or biotransformation routes (López et al., 2007b).

\subsection{Direct contact assays}

Table 3 gives the quantitative antimicrobial activity of PP and PET films coated with ATOX varnish containing different concentrations of OR and tested under the JIS Z 2801:2000 method (Anonymous, 2000). This standard was developed to measure the antibacterial activity of antibacterial-treated plastic products and other non-porous materials. In this study, the OR PET film coated with 4,6 and $8 \%$ of the antimicrobial compound did not allow recovering of cultivable cells from both $E$. coli 0157:H7 strains after $24 \mathrm{~h}$ incubation at $37^{\circ} \mathrm{C}$. These results demonstrate that the ORcontaining PET films had a strong antibacterial in vitro direct contact activity against both E. coli O157:H7 strains. Evaluation of PP films with ATOX varnish coating containing OR showed that 6 and $8 \%$ OR also completely inhibited the E. coli 0157:H7 type strain, which under $4 \%$ OR, had a $R$ value of 0.20 (a reduction of $38 \%$ ). However, for the milk strain E. coli 0157:H7 M364VO, the PP films containing 4 and 6\% OR allowed E. coli O157:H7 growth ( $R$ values of -0.41 and -0.23 , respectively) although under OR concentrations of $8 \%$ produced a reduction of $91.7 \%(R$ value $=1.08)$.

Our results show that by using the JIS Z 2801:2000 method, the OR PET films were more efficient than the OR PP films, the behaviour of the latter depending on the origin of the tested strain and the concentration of the active compound.

Table 4 shows the antimicrobial activity of LAE incorporated in the ACRIL varnish coating PP and PET films. No activity was observed against the tested strains at 0 and 4\% LAE. Results obtained with $0 \%$ LAE PP and 0\% LAE PET films suggest that, under the conditions of this test (incubation at $37^{\circ} \mathrm{C}$ ), manipulations required to prepare coated films without LAE did not affect the antibacterial

Table 3

Antimicrobial activity tested by a direct contact assay ${ }^{\mathrm{a}}$ of different concentrations of $\mathrm{OR}^{\mathrm{b}}(4,6$ and $8 \%$ incorporated in two packaging films against two E. coli O157:H7 strains.

\begin{tabular}{|c|c|c|c|c|c|c|}
\hline Strain & Film & OR concentration & $\begin{array}{l}\text { Film control after } \\
\text { inoculation }(\mathrm{cfu} / \mathrm{ml})\end{array}$ & $\begin{array}{l}\text { Film control after } 24 \mathrm{~h} \\
(\mathrm{cfu} / \mathrm{ml})\end{array}$ & $\begin{array}{l}\text { Coated films after } 24 \mathrm{~h} \\
(\mathrm{cfu} / \mathrm{ml})\end{array}$ & $R$ value $^{c}$ \\
\hline \multirow[t]{8}{*}{${\mathrm{M} 364 \mathrm{VO}^{g}}^{\mathrm{g}}$} & $\mathrm{PP}^{\mathrm{f}}$ & Varnish ATOX & $1.02 \times 10^{5 \mathrm{e}}$ & $5.40 \times 10^{6}$ & & \\
\hline & & $4 \%$ & & & $1.40 \times 10^{7}$ & -0.41 \\
\hline & & $6 \%$ & & & $9.20 \times 10^{6}$ & -0.23 \\
\hline & & $8 \%$ & & & $4.47 \times 10^{5}$ & 1.08 \\
\hline & $\mathrm{PET}^{\mathrm{i}}$ & Varnish ATOX & $1.90 \times 10^{5}$ & $7.00 \times 10^{4}$ & & \\
\hline & & $4 \%$ & & & $\mathrm{NG}^{\mathrm{h}}$ & \\
\hline & & $6 \%$ & & & NG & \\
\hline & & $8 \%$ & & & NG & \\
\hline \multirow[t]{8}{*}{ CECT $^{\mathrm{j}} 5947$} & PP & Varnish ATOX & $1.33 \times 10^{5}$ & $1.50 \times 10^{7}$ & & \\
\hline & & $4 \%$ & & & $9.43 \times 10^{6}$ & 0.20 \\
\hline & & $6 \%$ & & & NG & \\
\hline & & $8 \%$ & & & NG & \\
\hline & PET & Varnish ATOX & $1.57 \times 10^{5}$ & $1.20 \times 10^{5}$ & & \\
\hline & & $4 \%$ & & & NG & \\
\hline & & $6 \%$ & & & NG & \\
\hline & & $8 \%$ & & & NG & \\
\hline
\end{tabular}

\footnotetext{
${ }^{\text {a }}$ Activity tested by using Japanese standard JIS Z 2801:2000.

b Oregano essential oil obtained from Origanum vulgare. ones after $24 \mathrm{~h}$ incubation at $37^{\circ} \mathrm{C}$.

${ }^{\mathrm{d}}$ Films coated only with the varnish ( $\left.0 \% \mathrm{OR}\right)$.

e The values are means for counts obtained for three independent sample pieces.

${ }^{f}$ PP, Polypropylene.

S Strain from sheep milk.

${ }^{\mathrm{h}} \mathrm{NG}$, no growth. Viable cells were not recovered from the inoculated coated films after $24 \mathrm{~h}$ incubation at $37{ }^{\circ} \mathrm{C}$.

i PET, Polyethylene terephthalate.

j CECT, Spanish Type Culture Collection.
}

${ }^{c} R$ value was calculated using the formula $R=\log (B / C)$ where, $B$ : average of colony forming units (cfu) on the untreated films and $C$ : average of the cfu found on the treated 
Table 4

Antimicrobial activity tested by a direct contact assay ${ }^{\mathrm{a}}$ of different concentrations of LAE incorporated in two packaging films against two E. coli 0157:H7 strains.

\begin{tabular}{|c|c|c|c|}
\hline Strain & Film & $\mathrm{LAE}^{\mathrm{b}}$ concentration & Inhibition zone $(\mathrm{mm})^{\mathrm{c}}$ \\
\hline \multirow[t]{8}{*}{ M364VO } & $\mathrm{PP}^{\mathrm{e}}$ & Varnish ACRIL $^{\mathrm{d}}$ & 0 \\
\hline & & $4 \%$ & 0 \\
\hline & & $6 \%$ & 1 \\
\hline & & $8 \%$ & 2.5 \\
\hline & $\mathrm{PET}^{g}$ & Varnish ACRIL & 0 \\
\hline & & $4 \%$ & 0 \\
\hline & & $6 \%$ & 1.5 \\
\hline & & $8 \%$ & 2.5 \\
\hline \multirow[t]{8}{*}{$\mathrm{CECT}^{\mathrm{h}} 5947$} & PP & Varnish ACRIL & 0 \\
\hline & & $4 \%$ & 0 \\
\hline & & $6 \%$ & 1 \\
\hline & & $8 \%$ & 2.5 \\
\hline & PET & Varnish ACRIL & 0 \\
\hline & & $4 \%$ & 0 \\
\hline & & $6 \%$ & 1.5 \\
\hline & & $8 \%$ & 2.5 \\
\hline
\end{tabular}

a Activity tested by using an agar diffusion method as described by Iseppi et al (2008).

b Ethyl Lauroyl Arginate $\mathrm{HCl}$

c Clear zone of inhibition around the plastic film.

d Films coated only with the varnish ( $0 \%$ LAE).

e PP, Polypropylene.

f Strain from sheep milk.

$g$ PET, Polyethylene terephthalate.

h CECT, Spanish Type Culture Collection.

activity of the coated films. The activity, which was revealed by a clear zone of inhibition under and around the active films (between 1 and $2.5 \mathrm{~mm}$ ) demonstrated that 6\% LAE PET films were more efficient than 6\% LAE PP films although 8\% LAE PET and 8\% LAE PP films gave identical results ( $2.5 \mathrm{~mm}$ of inhibition zone).

As observed with the vapour phase assay, results obtained with the direct contact assays appear to depend on the packaging materials, the concentration of the active compound and the target microorganism.

\subsection{Antimicrobial activity in Zamorano sheep cheese}

The change in numbers of the $E$. coli $0157: \mathrm{H} 7$ strains during cold storage of inoculated Zamorano cheese slices placed between two pieces of PP or PET films coated with the varnishes alone and three different concentrations of each antimicrobial $(4,6$, and $8 \%)$ is given in Table 5. Statistical analysis demonstrated that counts were significantly $(p<0.05)$ affected by the film, the antimicrobial compound, the storage day and the tested strain.

After seven days of cold storage, 4\% OR PP films significantly $(p<0.05)$ decreased numbers of both E. coli 0157:H7 strains. PP films coated with 6 and $8 \%$ OR did not significantly $(p>0.05)$ reduce the counts. Overall, these results are not in agreement with data obtained with the in vitro tests (vapour phase assay and JIS Z 2801:2000 method) where the inhibition of the PP films increased with increasing OR concentrations (Tables 2 and 3 ).

In the cheese model, LAE PP films were only statistically significantly efficient $(p<0.05)$ in reducing E. coli $0157: \mathrm{H7}$ numbers when coated with $6 \%$ although the highest inhibition zones in the in vitro direct contact assay was obtained with $8 \%$ LAE PP films. The slight statistically significant decreases in cheese models (Table 5) when stored under 4\% OR PP and 6\% LAE PP films at $3{ }^{\circ} \mathrm{C}$ may be regarded as so small that they may not reflect meaningful inhibition. These data suggest that using PP antimicrobials food packaging films based on the release of OR and LAE, do not appear to be efficient against the target E. coli O157:H7 strains inoculated in Zamorano cheese. When the application of packaging films based on the release of LAE and OR from a number of films was studied against other Gram-negative pathogenic mesophilic strains (Salmonella) inoculated in food models, the reduction reported was much higher (Muriel-Galet et al., 2012a; Muriel-Galet et al., 2012b).

Data obtained with PET films coated with OR show that they significantly $(p<0.05)$ reduced levels of the tested strains when coated with $4 \%$ (type strain), and 6 and $8 \%$ (both strains). Similar results were observed for PET films coated with LAE although for $4 \%$ LAE, the significant $(p<0.05)$ reduction was for the milk strain. It

Table 5

Effects of two antimicrobial packaging films against two E. coli 0157:H7 strains inoculated on slices of Zamorano cheese.

\begin{tabular}{|c|c|c|c|c|c|c|c|c|}
\hline \multirow{2}{*}{$\frac{\text { Film }}{\mathrm{PP}^{\mathrm{c}}}$} & \multirow{2}{*}{$\begin{array}{l}\text { Antimicrobial } \\
\mathrm{OR}^{\mathrm{d}}\end{array}$} & \multirow{2}{*}{$\begin{array}{l}\text { Concentrations } \\
\text { Varnish ATOX }\end{array}$} & \multicolumn{3}{|c|}{ E. coli $0157: \mathrm{H} 7$ strain $\mathrm{M}^{264 \mathrm{VO}^{\mathrm{a}}}$} & \multicolumn{3}{|c|}{ E. coli $0157: \mathrm{H}^{2}$ strain $\mathrm{CECT}^{\mathrm{b}} 5947$} \\
\hline & & & Day 0 & Day 1 & Day 7 & Day 0 & Day 1 & Day 7 \\
\hline & & $0 \%$ & $\mathrm{e}, \mathrm{f} 4.37 \pm 0.11^{1,2}$ & $4.42 \pm 0.06^{1}$ & $4.26 \pm 0.14^{2}$ & $4.33 \pm 0.10^{1}$ & $4.37 \pm 0.19^{1}$ & $4.44 \pm 0.09^{1}$ \\
\hline & & $4 \%$ & $4.31 \pm 0.13^{1}$ & $4.26 \pm 0.07^{1}$ & $4.07 \pm 0.15^{2}$ & $4.40 \pm 0.06^{1}$ & $4.19 \pm 0.07^{2}$ & $3.95 \pm 0.12^{3}$ \\
\hline & & $6 \%$ & $4.32 \pm 0.21^{1,2}$ & $4.35 \pm 0.18^{1}$ & $4.18 \pm 0.25^{2}$ & $4.38 \pm 0.17^{1 ., 2}$ & $4.48 \pm 0.06^{1}$ & $4.32 \pm 0.07^{2}$ \\
\hline & & $8 \%$ & $4.16 \pm 0.13^{1}$ & $4.23 \pm 0.17^{1}$ & $4.16 \pm 0.11^{1}$ & $4.36 \pm 0.09^{1}$ & $4.13 \pm 0.08^{2}$ & $4.30 \pm 0.35^{1}$ \\
\hline & $\mathrm{LAE}^{g}$ & Varnish ACRIL & & & & & & \\
\hline & & $0 \%$ & $4.41 \pm 0.09^{1}$ & $4.30 \pm 0.08^{1, .2}$ & $4.22 \pm 0.06^{2}$ & $4.30 \pm 0.11^{1}$ & $4.29 \pm 0.07^{1}$ & $4.28 \pm 0.12^{1}$ \\
\hline & & $4 \%$ & $4.23 \pm 0.05^{1}$ & $4.12 \pm 0.21^{1}$ & $4.24 \pm 0.03^{1}$ & $4.33 \pm 0.20^{1,2}$ & $4.37 \pm 0.10^{1}$ & $4.19 \pm 0.11^{2}$ \\
\hline & & $6 \%$ & $4.47 \pm 0.12^{1}$ & $4.25 \pm 0.13^{2}$ & $4.22 \pm 0.14^{2}$ & $4.44 \pm 0.08^{1}$ & $4.30 \pm 0.08^{1.2}$ & $4.24 \pm 0.12^{2}$ \\
\hline & & $8 \%$ & $4.38 \pm 0.12^{1}$ & $4.29 \pm 0.05^{1}$ & $4.31 \pm 0.15^{1}$ & $4.47 \pm 0.18^{1}$ & $4.44 \pm 0.11^{1}$ & $4.53 \pm 0.05^{1}$ \\
\hline \multirow{10}{*}{$\mathrm{PET}^{\mathrm{h}}$} & OR & Varnish ATOX & & & & & & \\
\hline & & $0 \%$ & $4.44 \pm 0.07^{1}$ & $4.44 \pm 0.05^{1}$ & $4.38 \pm 0.04^{1}$ & $4.50 \pm 0.09^{1}$ & $4.32 \pm 0.09^{2}$ & $4.31 \pm 0.14^{2}$ \\
\hline & & $4 \%$ & $4.21 \pm 0.03^{1,2}$ & $4.12 \pm 0.05^{1}$ & $4.29 \pm 0.17^{2}$ & $4.45 \pm 0.07^{1}$ & $4.28 \pm 0.15^{2}$ & $3.99 \pm 0.15^{3}$ \\
\hline & & $6 \%$ & $4.46 \pm 0.22^{1}$ & $4.39 \pm 0.19^{1}$ & $4.07 \pm 0.04^{2}$ & $4.53 \pm 0.14^{1}$ & $4.42 \pm 0.07^{1}$ & $4.23 \pm 0.15^{2}$ \\
\hline & & $8 \%$ & $4.29 \pm 0.14^{1}$ & $4.26 \pm 0.12^{1}$ & $4.01 \pm 0.04^{2}$ & $4.36 \pm 0.15^{1}$ & $4.26 \pm 0.17^{1}$ & $4.11 \pm 0.09^{2}$ \\
\hline & LAE & Varnish ACRIL & & & & & & \\
\hline & & $0 \%$ & $4.35 \pm 0.09^{1,2}$ & $4.39 \pm 0.03^{1}$ & $4.21 \pm 0.09^{2}$ & $4.32 \pm 0.07^{1}$ & $4.30 \pm 0.16^{1}$ & $4.21 \pm 0.26^{1}$ \\
\hline & & $4 \%$ & $4.30 \pm 0.09^{1}$ & $4.27 \pm 0.04^{1}$ & $4.12 \pm 0.25^{2}$ & $4.35 \pm 0.05^{1,2}$ & $4.43 \pm 0.14^{1}$ & $4.21 \pm 0.15^{2}$ \\
\hline & & $6 \%$ & $4.47 \pm 0.03^{1}$ & $4.22 \pm 0.10^{2}$ & $4.13 \pm 0.16^{2}$ & $4.44 \pm 0.09^{1}$ & $4.32 \pm 0.06^{1}$ & $4.17 \pm 0.16^{2}$ \\
\hline & & $8 \%$ & $4.50 \pm 0.07^{1}$ & $4.23 \pm 0.17^{2}$ & $4.30 \pm 0.05^{2}$ & $4.44 \pm 0.08^{1}$ & $4.40 \pm 0.12^{1,2}$ & $4.28 \pm 0.09^{2}$ \\
\hline
\end{tabular}

\footnotetext{
a Strain from sheep milk.

b CECT, Spanish Type Culture Collection.

c PP, Polypropylene.

d Oregano essential oil obtained from Origanum vulgare.

e Each mean \pm standard deviation represents an average of six determinations.

${ }^{\mathrm{f}}$ Means on the same line with different superscript numbers are significantly different $(p<0.05)$.

g Ethyl Lauroyl Arginate $\mathrm{HCl}$.

h PET, Polyethylene terephthalate.
} 
should be noted that $6 \%$ OR and 6\% LAE PET were more efficient than $8 \%$ OR and 8\% LAE PET. Overall, in the Zamorano cheese model, the antimicrobial capacity of PET films was greater than that of PP films.

When studying the effectiveness of antimicrobial food packaging films, many antimicrobial systems that have shown strong activity when tested on model systems, do not demonstrate similar activity when tested in real food products. This, which is very common, is due not only to the target microorganisms but also to the interactive effects of a number of factors (Han, 2005). Amongst them are characteristics of the food such as $\mathrm{pH}, a_{w}$, fat and protein content, antioxidants, preservatives, salt and other additives and also extrinsic determinants such as the storage temperature and the atmosphere composition. Moreover, each food has its own characteristic microflora (Burt, 2004; Han, 2005; Quintavalla \& Vicini, 2002). The average physicochemical composition of Zamorano cheese wedges was: fat over dry matter, 45\%; protein, $25 \%$; $\mathrm{pH} 5.3 ; a_{w}, 0.95$ and $\mathrm{NaCl}$ content, $1.94 \%$. The dominant microflora, which is lactic acid bacteria, was over $9 \log$ units cfu/g. It should be noted that although E. coli 0157:H7 strains are mesophilic bacteria unable to grow under $7{ }^{\circ} \mathrm{C}$ some strains appear to possess unique genetic mechanisms enabling survival and proliferation under low temperature conditions (Vidovic, MangalappalliIllathu, \& Korber, 2011).

\subsection{Sensory analysis}

The value of the correlated Friedman statistic was $F^{\prime}=12.59$. For OR PP films, at $5 \%$ level of significance, the Friedman's test showed significant differences among samples $\left(F^{\prime}=48.58\right)$. The pairwise comparison for control samples and those packaged with OR-PP films showed significant differences $(p<0.05)$ after 24 h storage and also after seven days storage under $6 \%$ OR. No significant differences $(p>0.05)$ were established between OR PP packages of cold stored cheese slices kept for $24 \mathrm{~h}$ and seven days. The results indicate that for OR PP, panellists detected the OR flavour after $24 \mathrm{~h}$ and to a lesser extent after seven days storage. Panellists did not find significant differences $(p>0.05)$ for cheese slices packaged with LAE PP $\left(F^{\prime}=7.21\right)$ neither for OR PET $\left(F^{\prime}=9.70\right)$ and LAE PET $\left(F^{\prime}=12.3\right)$. Our data suggest that LAE and/or PET did not significantly affect sensorial characteristics of Zamorano cheese.

In conclusion, overall, the in vitro tests demonstrated the antimicrobial activity of PP and PET films coated with OR and LAE when tested against a wild and a reference E. coli 0157:H7 strains although the effect on the food model (Zamorano cheese) was moderately effective and most depend on the film and also on the antimicrobial agent. Our data suggest that PET films coated with $\geq 6 \%$ LAE concentrations might be useful in reducing $E$. coli $\mathrm{O} 157: \mathrm{H7}$ numbers in sheep cheese.

\section{Acknowledgements}

Verónica Otero was beneficiary of a grant from the FPU program of the Spanish Government. This work was financed by Junta de Castilla y León (Ayuda Grupo de Excelencia GR155) and partially by the Junta project LE331A12-2 and also by the project AGL201126118/ALI of the Spanish R\&D program. We are grateful for the valuable collaboration of Artibal S.A. (Sabiñánigo, Huesca, Spain). Thanks are also given to the Gobierno de Aragón and Fondo Social Europeo for financial help given to GUIA research Group T-10.

\section{References}

Anonymous. (2000). JIS Z 2801:2000. Antimicrobial products - Test for antimicrobial activity and efficacy. Japanese Standards Association.
Anonymous. (2006). ISO 8587:2006. Sensory analysis. Methodology. Ranking. International Organization for Standardization.

Anonymous. (2013), ISO 8587:2006/Amd 1:2013. Sensory analysis. Methodology. Ranking. International Organization for Standardization.

Becerril, R., Gomez-Lus, R., Goni, P., Lopez, P., \& Nerin, C. (2007). Combination of analytical and microbiological techniques to study the antimicrobial activity of a new active food packaging containing cinnamon or oregano against E. coli and S. aureus. Analytical and Bioanalytical Chemistry, 388(5-6), 1003-1011.

Burt, S. (2004). Essential oils: their antibacterial properties and potential applications in foods-a review. International Journal of Food Microbiology, 94(3), 223253.

Burt, S. A., \& Reinders, R. D. (2003). Antibacterial activity of selected plant essential oils against Escherichia coli 0157:H7. Letters in Applied Microbiology, 36(3), 162167.

Caro, I., \& García-Armesto, M. R. (2007). Occurrence of Shiga toxin-producing Escherichia coli in a Spanish raw ewe's milk cheese. International Journal of Food Microbiology, 116(3), 410-413.

Caro, I., Mateo, J., Rúa, J., \& García-Armesto, M. R. (2011). Occurrence of Escherichia coli 0157, 0111 and 026 in raw ewe's milk and performance of two enrichment broths and two plating media used for its assessment. International Journal of Food Microbiology, 146(1), 84-87.

Cha, D. S., \& Chinnan, M. S. (2004). Biopolymer-based antimicrobial packaging: a review. Critical Reviews in Food Science and Nutrition, 44(4), 223-237.

Espié, E., Vaillant, V., Mariani-Kurkdjian, P., Grimont, F., Martin-Schaller, R., De Valk, H., et al. (2006). Escherichia coli 0157 outbreak associated with fresh unpasteurized goats' cheese. Epidemiology and Infection, 134(1), 143-146.

European Commission. (2009). Commission regulation (EC) No 450/2009 of 29 May 2009 on active and intelligent materials and articles intended to come into contact with food. Official Journal of the European Union, L135, 3-11.

Farrokh, C., Jordan, K., Auvray, F., Glass, K., Oppegaard, H., Raynaud, S., et al. (2013). Review of Shiga-toxin-producing Escherichia coli (STEC) and their significance in dairy production. International Journal of Food Microbiology, 162(2), 190-212.

Ferens, W. A., \& Hovde, C. J. (2011). Escherichia coli 0157:H7: animal reservoir and sources of human infection. Foodborne Pathogens and Disease, 8(4), 465-487.

Gutiérrez, L., Batlle, R., Sánchez, C., \& Nerín, C. (2010). New approach to study the mechanism of antimicrobial protection of an active packaging. Foodborne Pathogens and Disease, 7(9), 1063-1069.

Han, J. H. (2005). Introduction to active food packaging technologies. In J. H. Han (Ed.), Innovations in food packaging (pp. 80-107). London: Academic Press.

Iseppi, R., Pilati, F., Marini, M., Toselli, M., de Niederhäusern, S., Guerrieri, E., et al. (2008). Anti-Listerial activity of a polymeric film coated with hybrid coatings doped with Enterocin 416K1 for use as bioactive food packaging. International Journal of Food Microbiology, 123(3), 281-287.

López, P., Sánchez, C., Batlle, R., \& Nerín, C. (2007a). Development of flexible antimicrobial films using essential oils as active agents. Journal of Agricultural and Food Chemistry, 55(21), 8814-8824.

López, P., Sánchez, C., Batlle, R., \& Nerín, C. (2007b). Vapor-phase activities of cinnamon, thyme, and oregano essential oils and key constituents against foodborne microorganisms. Journal of Agricultural and Food Chemistry, 55(11), 43484356.

Marino, M., Bersani, C., \& Comi, G. (2001). Impedance measurements to study the antimicrobial activity of essential oils from Lamiaceae and Compositae. International Journal of Food Microbiology, 67(3), 187-195.

Meng, J., Lejeune, J. T., Zhao, T., \& Doyle, M. P. (2013). Enterohemorrhagic Escherichia coli. In M. P. Doyle, \& R. L. Buchanan (Eds.), Food microbiology: Fundamentals and frontiers (pp. 287-310). Washington, DC: ASM Press.

Muriel-Galet, V., Cerisuelo, J. P., López-Carballo, G., Lara, M., Gavara, R., \& Hernández-Muñoz, P. (2012a). Development of antimicrobial films for microbiological control of packaged salad. International Journal of Food Microbiology, 157(2), 195-201.

Muriel-Galet, V., López-Carballo, G., Gavara, R., \& Hernández-Muñoz, P. (2012b). Antimicrobial food packaging film based on the release of LAE from EVOH. International Journal of Food Microbiology, 157(2), 239-244.

Nataro, J. P., \& Kaper, J. B. (1998). Diarrheagenic Escherichia coli. Clinical Microbiology Reviews, 11(1), 142-201.

Nerin, C. (2012). Essential oils in active packaging. In L. Valgimigli (Ed.), Essential oils as natural food additives: Composition, applications, antioxidant and antimicrobial properties (pp. 397-412). Nova Science Inc.

Nerin, C., \& Garcés, O. (2006). Antimicrobial packaging based on the use of natural extracts and the process to obtain this packaging. European Patent Application EP $1657181 \mathrm{~A} 1$.

Quintavalla, S., \& Vicini, L. (2002). Antimicrobial food packaging in meat industry. Meat Science, 62(3), 373-380.

Rey, J., Sánchez, S., Blanco, J. E., Hermoso de Mendoza, J., Hermoso de Mendoza, M., García, A., et al. (2006). Prevalence, serotypes and virulence genes of Shiga toxin-producing Escherichia coli isolated from ovine and caprine milk and other dairy products in Spain. International Journal of Food Microbiology, 107(2), 212217.

Rodriguez, A., Nerin, C., \& Batlle, R. (2008). New cinnamon-based active paper packaging against Rhizopus stolonifer food spoilage. Journal of Agricultural and Food Chemistry, 56(15), 6364-6369.

Rodriguez, E., Seguer, J., Rocabayera, X., \& Manresa, A. (2004). Cellular effects of monohydrochloride of $\mathrm{L}$-arginine, $\mathrm{N}^{\alpha}$-lauroyl ethylester (LAE) on exposure to Salmonella typhimurium and Staphylococcus aureus. Journal of Applied Microbiology, 96(5), 903-912. 
Rooney, M. L. (2005). Introduction to active food packaging technologies. In J. H. Han (Ed.), Innovations in food packaging (pp. 63-79). London: Academic Press.

Sacchetti, G., Maietti, S., Muzzoli, M., Scaglianti, M., Manfredini, S., Radice, M., et al (2005). Comparative evaluation of 11 essential oils of different origin as functional antioxidants, antiradicals and antimicrobials in foods. Food Chemistry, 91(4), 621-632.

Suppakul, P., Miltz, J., Sonneveld, K., \& Bigger, S. W. (2003). Active packaging technologies with an emphasis on antimicrobial packaging and its applications. Journal of Food Science, 68(2), 408-420.
Theinsathid, P., Visessanguan, W., Kruenate, J., Kingcha, Y., \& Keeratipibul, S. (2012). Antimicrobial activity of lauric arginate-coated polylactic acid films against Listeria monocytogenes and Salmonella typhimurium on cooked sliced ham. Journal of Food Science, 77(2), M142-M149.

Vidovic, S., Mangalappalli-Illathu, A. K., \& Korber, D. R. (2011). Prolonged cold stress response of Escherichia coli 0157 and the role of rpoS. International Journal of Food Microbiology, 146(2), 163-169. 

1 Prevalence of Shiga toxin-producing Escherichia coli (STEC) in bulk tank ewes' milk

2 and sheep farm environment.

3

$4 \quad$ Verónica Otero (votea@unileon.es) $)^{\mathrm{a}}$, Sergio Sánchez (sergio.sanchez@isciii.es) $)^{\mathrm{b}}$, Silvia

5 Herrera-León (sherrera@isciii.es)

6 Andrés Otero (andres.otero@unileon.es) ${ }^{\mathrm{a}}$, María-Luisa García-López (mlgarl@unileon.es),

7 Jesús A. Santos (j.santos@unileon.es)*a

$8{ }^{a}$ Department of Food Hygiene and Food Technology, Veterinary Faculty, University of

9 León, Spain

10 b Laboratorio de Enterobacterias, Servicio de Bacteriología, Centro Nacional de

11 Microbiología, Instituto de Salud Carlos III, 28220 Madrid, Spain

12

$13 *$ Corresponding author

14 Jesús A. Santos

15 Departamento de Higiene y Tecnología de los Alimentos

16 Facultad de Veterinaria, Universidad de León

17 E-24071-León, Spain

18 Phone: +34 987291119

19 Fax: +34 987291284

Email: j.santos@unileon.es 
Abstract

The aims of this study were to evaluate the prevalence of Shiga toxin-producing Escherichia coli (STEC) in bulk tank ewes’ milk and farm environment in Castilla y León (Northwest Spain) and to characterize the isolates obtained to gain information on reservoirs and sources of contamination. Also, a commercial immunoassay for detection of Shiga toxins was tested to evaluate its possible usefulness for ewes’ milk analysis.

A total of 388 milk samples and samples from air, water, feed and faeces from 10 farms were examined by PCR. stx genes were detected in 176 (45.36 \%) milk samples, 9 (45 \%) water samples and 5 (25\%) faeces samples. A total of 62 isolates were obtained, four of them belonging to serotype O157:H7 (three from milk samples and one from water samples). All the samples of bulk tank milk tested with the immunoassay yielded negative results.

In conclusion, Spanish bulk tank ewes’ milk can constitute a source of STEC, but the overall prevalence of serotypes involved in human disease is low. The environment of the dairy farm may represent an important reservoir of this microorganism, particularly drinking water.

41 Keywords: Shiga toxin-producing E. coli; STEC; sheep milk; E. coli O157:H7 


\section{Introduction}

Pathogenic Escherichia coli are regarded as emerging human pathogens. Among them, Shiga toxin-producing E. coli (STEC) are the agents of severe diseases in humans, such as haemorrhagic colitis and haemolytic uremic syndrome (HUS) (Meng, et al., 2013). The main virulence factor in STEC is the production of Shiga toxin (Stx) 1 and Stx 2 or the several variants described of those toxins, but pathogenic strains usually produce other factors, such as intimin or enterohaemolysin, which are involved in the pathogenicity by mediating in the attachment of STEC to cell membranes and in the inflammatory response, respectively (Nataro and Kaper, 1998; Paton and Paton, 1998b). Strains belonging to serotype O157:H7 are of special relevance, because of the high virulence, but other nonO157 STEC serotypes are also of concern because of their implication in foodborne human disease, the $\mathrm{O} 104$ being a recent example of an emerging serotype involved in large outbreaks (Grad, et al., 2012; Johnson, et al., 2006; Scheutz, et al., 2011).

Cattle and other ruminants, as sheep and goat, are considered the main reservoir of STEC, which is transmitted to human via contaminated foods (meat, milk and derived products), but a variety of foods of animal and plant origin have been incriminated in foodborne outbreaks as well (Blanco, et al., 2003a; Karmali, et al., 2010; Meng, et al., 2013). Detection of STEC in foods is difficult to achieve, taking into account the diversity of phenotypic characteristics of the strains involved. As an alternative, PCR amplification of stx genes in enrichment cultures, followed by careful colony examination is the method of choice by the majority of laboratories, but direct detection of Stx toxins can also be done by immunoassays, which have been developed to check for the presence of Stx toxins in human stools, but can be of use to analyze food samples as well (Acheson, et al., 1996).

Animals carrying STEC strains can disseminate them in the farm environment, thus becoming a reservoir for recontamination of other animals and also for direct transmission to 
humans (Farrokh, et al., 2013). Several studies have investigated the presence of STEC in faecal samples obtained from sheep, but no other environmental samples, as air or water have been tested in sheep farms to our knowledge, whereas in dairy cattle the farm environment has been demonstrated to maintain detectable levels of STEC (Berry and Wells, 2010).

Ewe breeding is an important activity in Spain (20\% of the EU breeding ewe flock), with more than $75 \%$ of the Spanish production of ewe milk concentrated in the interior regions. The majority of the milk is transformed into raw milk cheeses, which have been shown to carry STEC strains, even after a long ripening period (Caro and García-Armesto, 2007).

The aims of this work were to study the prevalence of STEC in bulk tank ewes' milk and farm environments and to characterize the isolates obtained from these samples to gain information on reservoirs and sources of contamination. An additional task was to examine the usefulness of a commercial immunoassay for detection of Shiga toxins in ewes’ milk.

\section{Materials and methods}

\subsection{Sample Collection}

In this study samples of bulk tank ewes' milk were collected from 388 farms located along different collection routes in Castilla y León (Northwest Spain), during the period of June 2009 to June 2010. The majority of the samples (215) were taken in spring, the rest of the samples corresponding to winter (89), summer (52) and autumn (32), reflecting the periods of milk production. Milk samples of $100 \mathrm{ml}$ were aseptically taken in sterile containers.

Additional environmental samples from air, water, feed and faeces were taken from 10 farms, which were previously demonstrated as positive for the presence of STEC. The 
environmental samples were collected at two different times, May (spring season) and September (summer season). Ten litre air samples were collected using a Microbial Air Sampler (Biotest Hycon, Dreieich, Germany) fitted with a Tryptone Soy Agar (TSA; Oxoid, Basingstoke, UK) strip. Water troughs and feed samples were taken in sterile containers. Sampling of faeces in farm premises was done with boot swabs following the protocol outlined in the EU for monitoring the reduction of Salmonella in laying hens (European Commission, 2011). In brief, two pairs of boot swabs, moistened with a solution of $0.1 \%$ peptone and $0.9 \% \mathrm{NaCl}$, were used to walk through the premises using a route that produced a sample for all parts of the farm. Boot swabs were removed carefully and stored in sterile zip-bags for transport to the laboratory.

Milk and farm environment samples were immediately transported to the laboratory in an insulated cooler.

\subsection{Sample processing}

Fifty $\mathrm{ml}$ of milk were cultured in $450 \mathrm{ml}$ of Tryptone Soy Broth (TSB; Oxoid) plus $0.6 \%$ yeast extract (TSBYE; Oxoid) at $42{ }^{\circ} \mathrm{C}$ for $18 \mathrm{~h}$. A sample of one ml was taken and centrifuged at $13000 \mathrm{~g}$ for $3 \mathrm{~min}$; the supernatant was discarded and the pellet was washed twice with $1 \mathrm{ml}$ of Phosphate buffered saline (PBS, Oxoid) and finally suspended in $300 \mu \mathrm{l}$ of double-distilled water with 1 \% Triton X-100 (Sigma-Aldrich Química, S.A., Madrid, España) and 2 \% Chelex 100 Resin (Bio-Rad Laboratories, Hercules, CA, USA). DNA was released by heating at $100{ }^{\circ} \mathrm{C}$ for $15 \mathrm{~min}$ and the DNA preparations were centrifuged at $13000 \mathrm{~g}$ for $3 \mathrm{~min}$ and the supernatants transferred to a clean tube and stored at $-20{ }^{\circ} \mathrm{C}$ until needed. A loopful of the enriched sample was streaked onto CT-SMAC (Oxoid) plates and incubated at $37^{\circ} \mathrm{C}$ for $24 \mathrm{~h}$. Another loopful was streaked onto Enterohaemolysin agar plates (Beutin, et al., 1989) and observed after $4 \mathrm{~h}$ and $24 \mathrm{~h}$ of incubation at $37^{\circ} \mathrm{C}$. A minimum of 
ten pink (sorbitol fermenters) and colourless (non fermenters) colonies in CT-SMAC and haemolytic colonies after $24 \mathrm{~h}$ but not after $4 \mathrm{~h}$ of incubaction in Enterohaemolysin agar were picked, checked for purity on TSA (Oxoid) and streaked onto CT-SMAC and MacConkey Agar (Oxoid) to record lactose and sorbitol fermentation. Pure colonies were preserved at $-40{ }^{\circ} \mathrm{C}$ in TSB plus $40 \%$ Glycerol for further characterization. TSA strips from the air sampling were homogenized with $50 \mathrm{ml}$ of TSBYE in a BagMixer 400blender (Interscience, Saint-Nom-la-Bretèche, France). Water samples (250 ml) were filtered through sterile $0.45 \mu \mathrm{m}$ filters which were then incubated in $50 \mathrm{ml}$ TSBYE. Twenty five g of feed material were blended with $225 \mathrm{ml}$ of TSBYE. Boot swabs were unpacked and placed in $225 \mathrm{ml}$ of TSBYE. All cultures were processed as described above for DNA preparation and colony isolation.

\subsection{Shiga toxin detection in enriched milk samples}

ProSpecT Shiga Toxin Microplate Assay (Remel, Lenexa, KS, USA) was used as a rapid method for the detection of Shiga toxin in bulk tank milk samples. An aliquot of 0.3 $\mathrm{ml}$ of the enriched milk sample was processed as described by the manufacturer. The results of the assay were read at $450 \mathrm{~nm}$ in a Multiskan FC microplate spectrophotometer (Thermo Fisher Scientific Inc, Waltham, MA) and considered positive when the optical density was greater than 0.150 . Previous experiments were carried out with raw and freshly pasteurized ewes' milk spiked with 1, 10 and $10^{5} \mathrm{cfu} / \mathrm{ml}$ of the E. coli O157:H7 strain CECT 4076 (CECT, Spanish Culture Collection, Valencia, Spain) and cultured in TSBYE as already described. The ProSpecT Shiga Toxin Microplate Assay offered different performance depending upon the type of milk used for previous experiments. Thus, with spiked pasteurized milk, a positive result was observed after enrichment for the three levels of 
143 inoculum, 1,10 and $10^{5} \mathrm{cfu} / \mathrm{ml}$. On the other hand, with spiked raw milk, a level of

144 inoculum of $10^{5} \mathrm{cfu} / \mathrm{ml}$ was needed to detect Shiga toxin.

\subsection{PCR assays}

PCR detection of stx 1 and stx2 genes was carried out on DNA preparations obtained from enriched samples using primers and conditions shown in Table 1 (Paton and Paton, 1998a). Colonies picked from CT-SMAC and Enterohaemolysin agar plates were cultured in TSB at $37^{\circ} \mathrm{C}$ overnight and $1 \mathrm{ml}$ was centrifuged at $13000 \mathrm{~g}$ for $3 \mathrm{~min}$ and the pellet was used for DNA preparation as described above. All the isolates considered as STEC were additionally tested for a number of PCR assays: subtypes of stx genes, intimin (eae gene) and intimin variant $\gamma 1$ (eae 1 gene) and enterohaemolysin (hlyA gene) (Gannon, et al., 1993; Oswald, et al., 2000; Scheutz, et al., 2012; Wang, et al., 2002). Primers and amplicon sizes are listed in Table 1 . PCR products $(5 \mu \mathrm{l})$ were analyzed by $1.5 \%$ agarose gel electrophoresis and viewed after ethidium bromide staining under UV light.

\subsection{Serological test}

Latex agglutination assays Dryspot E. coli 0157 latex test and Dryspot E. coli seroscreen (Oxoid) were used to identify the O157 and O26, O91, O103, O111, O128 and O145 serogroups respectively, according to manufacturer’s instructions.

Additional serotype identification was carried out by PCR detection of target genes for the antigens O26, O45, O91, O103, O104, O111, O121, O128, O145, O146, and H7 (Table 2). Flagellar $(\mathrm{H})$ antigen typing was carried out for the isolates presenting any of the somatic antigens studied. PCR amplification of a fragment of the fliC gene was done using the primers FliC-F and FliC-R described by Machado et al. (2000) and the PCR products were purified with a Invisorb DNA Clean Up kit (STRATEC Molecular GMBH, Berlin, 
Germany). Both strands were sequenced in a 3730xl DNA Analyzer (Applied Biosystems, Foster City, CA, US). Sequences were edited using the Lasergene software (DNASTAR, Inc., Madison, WI) and compared against sequences registered in GenBank database using the BLAST tool.

\subsection{Statistical analysis}

To evaluate the effect of the season in the prevalence of stx-positive milk samples, a chisquare test was carried out with the SPSS software (SPSS Version 19.0; SPSS Inc, Chicago, IL) with a value of $\mathrm{p} \leq 0.05$ and a confidence level of 0.95 .

\section{Results}

\subsection{Shiga toxin detection in milk}

All the samples of bulk tank milk yielded negative results for Shiga toxin detection.

\subsection{PCR detection of stx genes in milk and environmental samples}

A total of 176 out of 388 (45.36 \%) bulk tank milk samples were positive for the presence of one or both stx genes. Thirty-five of these positive samples presented the stx1 gene, 39 the stx2 and 102 had both genes. Milk samples taken in winter and spring showed higher prevalence of stx genes than summer and autumn samples. Regarding environmental samples, air and feed samples were always negative for stx genes. Nine out of 20 (45 \%) water samples were positive for stx2 (8 samples, $40 \%$ ) or both stx1 and stx2 (1 sample, $5 \%$ ) genes, whereas five faeces samples (25\%) were positive for stx2 gene (Table 3).

\subsection{STEC isolation and characterization}



corresponded to samples taken in 34 farms (8.76 \%), whereas two isolates were from 20 water samples $(10 \%$; one from the spring sampling and the other from the summer sampling, obtained from different farms) and ten isolates ( 5 from spring season and 5 from summer season) from 20 ovine faeces samples (50 \%). One farm yielded positive isolation in both water and faeces samples in the summer season and three farms were positive for STEC isolation from faeces in both seasons. The majority of isolates ( $75.8 \%$; 47 out of 62) carried the stx1 gene, 45 of them the subtype stx1c and two the subtype stx1a. All but one of them carried the hlyA gene and the isolate of the subtype stx1a being positive for amplification of eae gene as well. Thirty seven isolates were obtained from milk samples, 9 from ovine faeces and 1 from water. Four milk isolates were found in samples which were negative for stx amplification, whereas 11 samples carried the stx 1 gene, 23 st $x 1$ and stx 2 and 9 stx 2 . Four isolates, three from milk and one from water samples, were positive for stx 2 amplification and all of them showed the same genetic profile (stx2c, fliCh7, eae, eaer1, hlyA) and were ascribed to serotype O157:H7. The remaining 11 isolates (10 from milk and one from ovine faeces) carried both stx1/stx2 genes and two of them were serotyped as O146:H21. In total, only six isolates were assigned to serotypes (four O157:H7 and two O146:H21). The results are summarized in Table 4. A complete dataset for the 62 isolates is supplied as supplementary information (Table S1).

\section{Discussion}

STEC is a diverse group of microorganisms which differ in phenotypic traits as well as in pathogenicity to humans. Detection from foods can be difficult because isolation plates are usually overcrowded due to growth of competing microbiota (Farrokh, et al., 2013). 
217 Enzyme immunoassays are a practical way to overcome some of these problems, because they are targeted to the common factor among all STEC, the Shiga toxin; event though they are primarily developed for testing human stools, several authors have used them for screening foods and bovine faeces with promising results (Acheson, et al., 1996; Willford, et al., 2009). In our study, the performance of the assay kit was highly sensitive when it was used with spiked samples of pasteurized milk, but raw milk showed less sensitivity, indicating a probable interference of the original microbiota. All the samples of bulk tank milk tested yielded negative results, which mean that the level of STEC was very low to be detected by this procedure.

Analysis of enriched milk samples by PCR showed an overall prevalence of STEC of 45.36 \%, a figure considerably higher than those previously reported for ewes’ milk by other authors in Europe (between ca. 10 and 20 \%; Caro, et al., 2006; Muehlherr, et al., 2003; Rey, et al., 2006; Zdragas, et al., 2009). The prevalence of positive samples was higher in spring and winter, as it was observed previously in ewes’ milk with other bacterial groups, probably because of seasonal management practices (confinement in winter and spring and grazing in summer and autumn; de Garnica, et al., 2013). Fecal carriage of STEC by ruminants is well documented, thus the detection of stx gene among samples of faeces taken in the premises was expected. Drinking water can also disseminate STEC within the flock, probably due to direct or indirect contamination with faeces, but may serve as a reservoir of this microorganism and a route for dissemination to animals (Berry and Wells, 2010; LeJeune, et al., 2001). Feed, previous to exposure to animals, is not considered as a vehicle for transmission of STEC, although some contamination may occur in the feed trough (Berry and Wells, 2010). In our study, samples were collected before feeds being distributed in the feed bunks, thus explaining the lack of detection of STEC. It also seems that air is not a suitable vehicle for transmission of STEC in sheep farms. 

total of 50 isolates were obtained, with 13 samples carrying more than one strain, which could be differentiated phenotypically by their patterns of lactose and sorbitol fermentation. The rate of isolation (8.76 \% of bulk tank milk samples) was higher than the rate obtained in similar studies, between $1 \%$ and $4.76 \%$ (Dontorou, et al., 2004; Muehlherr, et al., 2003; Rey, et al., 2006). It is noteworthy that some isolates were obtained from samples considered stx-negative by PCR. Common procedures for study the prevalence of STEC in foods and other samples do not include direct PCR detection from enrichment cultures or, when this step is performed, only positive results are taking into account (Muehlherr, et al., 2003), but it has been shown with other bacteria that a negative PCR result could yield a positive isolation from plates (Sails, et al., 2003). DNA template degradation, presence of inhibitors or interference due to high levels of non-target microorganisms are among the possible explanations to this occurrence. STEC from ewes' milk and this fact could be related to the enrichment procedure employed, with no antibiotic added to the culture broth and a temperature of $42{ }^{\circ} \mathrm{C}$. Some of the studies carried out on ewes' milk used enrichment broth supplemented with novobiocin at $37^{\circ} \mathrm{C}$, which has been reported to inhibit some STEC strains (Vimont, et al., 2006). from a water sample taken from a farm where other strains were isolated, both from bulk tank milk and from faeces, but those isolates carried the stx1 gene and lacked the eae gene. The presence of strains of STEC O157:H7 in sheep has been demonstrated (Blanco, et al., 2003b; Rey, et al., 2003), but its isolation from ewes’ milk is not always achieved. At the 
same time, its isolation from livestock drinking water is of concern, as it has been confirmed that drinking water contaminated with E. coli O157:H7 can disseminate this organism to cattle (Berry and Wells, 2010; LeJeune, et al., 2001). The intimin type of E. coli O157:H7 isolates $(\gamma 1)$ is common among ovine isolates and is also associated with pathogenic human strains (Blanco, et al., 2003b; Oswald, et al., 2000; Rey, et al., 2003). Two other milk isolates carried a non- $\gamma 1$ eae gene, the association of the presence of the eae gene and the virulence of STEC strains has been pointed by numerous authors (Blanco, et al., 2003b; Boerlin, et al., 1999; Oswald, et al., 2000; Werber, et al., 2003). However, even though the majority of the isolates lacked the eae gene, this fact must not be considered as a proof of safety; it is well known that eae-negative strains are associated with human disease, though they cause less severe illness than proper EHEC strains (those Stx and eae positives; Kaper, et al., 2004).

Two additional milk isolates belonged to serotype O146:H21, which is commonly found in sheep, and carried both stx 1 and stx2 genes, a feature described by other authors (Beutin, et al., 2007; Blanco, et al., 2003b; Rey, et al., 2003). This serotype has also been found in human STEC strains (Blanco, et al., 2003b).

In total, only six out of 62 isolates were assigned to any of the studied serotypes, which included the most important serotypes implicated in human disease. It is remarkable that the serotype O91 was absent among the isolates, taking into account that it is one of the most prevalent serotypes found in sheep in Spain (Blanco, et al., 2003b; Rey, et al., 2003). In conclusion, Spanish bulk tank ewes’ milk can constitute a source of STEC transmission to humans, but the overall prevalence of serotypes involved in human disease is low. The environment of the dairy farm may represent an important reservoir of this microorganism, particularly drinking water. Milking hygiene and preventive hygienic 
measures at farm level should be considered to reduce the contamination of raw ewes' milk intended for human consumption or manufacturing of raw milk cheeses.

\section{Acknowledgements}

This work was financed by project AGL2011-26118/ALI of the Spanish R\&D program and Junta de Castilla y León (Ayuda Grupo de Excelencia GR155). Verónica Otero was supported by a grant from the FPU program of the Spanish Government.

\section{References}

Acheson, D. W. K., Lincicome, L. L., De Breucker, S. \& Keusch, G. T. (1996). Detection of Shiga-like toxin-producing Escherichia coli in ground beef and milk by commercial enzyme immunoassay. Journal of Food Protection, 59, 344-349.

Berry, E. D. \& Wells, J. E. (2010). Escherichia coli O157: H7: Recent Advances in Research on Occurrence, Transmission, and Control in Cattle and the Production Environment. Advances in Food and Nutrition Research, 60, 67-117.

Beutin, L., Miko, A., Krause, G., Pries, K., Haby, S., Steege, K. \& Albrecht, N. (2007). Identification of human-pathogenic strains of Shiga toxin-producing Escherichia coli from food by a combination of serotyping and molecular typing of Shiga toxin genes. Applied and Environmental Microbiology, 73, 4769-4775.

Beutin, L., Montenegro, M. A., Orskov, I., Orskov, F., Prada, J., Zimmermann, S. \& Stephan, R. (1989). Close association of verotoxin (Shiga-like toxin) production with enterohemolysin production in strains of Escherichia coli. Journal of Clinical Microbiology, 27, 2559-2564.

Blanco, J., Blanco, M., Blanco, J. E., Mora, A., Gonzalez, E. A., Bernardez, M. I., Alonso, M. P., Coira, A., Rodriguez, A., Rey, J., Alonso, J. M. \& Usera, M. A. (2003a). 

genes of O157:H7 and non-O157 VTEC in ruminants, raw beef products, and humans. Experimental Biology and Medicine, 228, 345-351.

Blanco, M., Blanco, J. E., Mora, A., Rey, J., Alonso, J. M., Hermoso, M., Hermoso, J.,

Alonso, M. P., Dahbi, G., Gonzalez, E. A., Bernardez, M. I. \& Blanco, J. (2003b).

Serotypes, virulence genes, and intimin types of Shiga toxin (verotoxin)-producing Escherichia coli isolates from healthy sheep in Spain. Journal of Clinical Microbiology, $41,1351-1356$.

Boerlin, P., McEwen, S. A., Boerlin-Petzold, F., Wilson, J. B., Johnson, R. P. \& Gyles, C. L. (1999). Associations between virulence factors of Shiga toxin-producing Escherichia coli and disease in humans. Journal of Clinical Microbiology, 37, 497-503.

Bugarel, M., Beutin, L., Martin, A., Gill, A. \& Fach, P. (2010). Micro-array for the identification of Shiga toxin-producing Escherichia coli(STEC) seropathotypes associated with Hemorrhagic Colitis and Hemolytic Uremic Syndrome in humans. International Journal of Food Microbiology, 142, 318-329.

Caro, I. \& García-Armesto, M. R. (2007). Occurrence of Shiga toxin-producing Escherichia coli in a Spanish raw ewe's milk cheese. International Journal of Food Microbiology, $116,410-413$.

Caro, I., Fernandez-Barata, V. M., Alonso-Llamazares, A. \& Garcia-Armesto, M. R. (2006). Detection, occurrence, and characterization of Escherichia coli O157: H7 from raw ewe's milk in Spain. Journal of Food Protection, 69, 920-924.

de Garnica, M., Linage, B., Carriedo, J., De La Fuente, L., García-Jimeno, M., Santos, J. \& Gonzalo, C. (2013). Relationship among specific bacterial counts and total bacterial and somatic cell counts and factors influencing their variation in ovine bulk tank milk. Journal of Dairy Science, 96, 1021-1029. 
Dontorou, A., Papadopoulou, C., Filioussis, G., Apostolou, I., Economou, V., Kansouzidou, A. \& Levidiotou, S. (2004). Isolation of a rare Escherichia coli O157:H7 strain from farm animals in Greece. Comparative Immunology, Microbiology and Infectious Diseases, 27, 201-207.

European Commission. (2011). Commission Regulation (EU) No 517/2011 of 25 May 2011 implementing Regulation (EC) No 2160/2003 of the European Parliament and of the Council as regards a Union target for the reduction of the prevalence of certain Salmonella serotypes in laying hens of Gallus gallus and amending Regulation (EC) No 2160/2003 and Commission Regulation (EU) No 200/2010. Official Journal of of the European Union, L138, 45-51.

Farrokh, C., Jordan, K., Auvray, F., Glass, K., Oppegaard, H., Raynaud, S., Thevenot, D., Condron, R., De Reu, K., Govaris, A., Heggum, K., Heyndrickx, M., Hummerjohann, J., Lindsay, D., Miszczycha, S., Moussiegt, S., Verstraete, K. \& Cerf, O. (2013). Review of Shiga-toxin-producing Escherichia coli (STEC) and their significance in dairy production. International Journal of Food Microbiology, 162, 190-212.

Gannon, V. P., Rashed, M., King, R. K. \& Thomas, E. J. (1993). Detection and characterization of the eae gene of Shiga-like toxin-producing Escherichia coli using polymerase chain reaction. Journal of Clinical Microbiology, 31, 1268-1274.

Gannon, V. P., D'Souza, S., Graham, T., King, R. K., Rahn, K. \& Read, S. (1997). Use of the flagellar H7 gene as a target in multiplex PCR assays and improved specificity in identification of enterohemorrhagic Escherichia coli strains. Journal of Clinical Microbiology, 35, 656-662.

Grad, Y. H., Lipsitch, M., Feldgarden, M., Arachchi, H. M., Cerqueira, G. C., Fitzgerald, M., Godfrey, P., Haas, B. J., Murphy, C. I., Russ, C., Sykes, S., Walker, B. J., Wortman, J. R., Young, S., Zeng, Q., Abouelleil, A., Bochicchio, J., Chauvin, S., Desmet, T., Gujja, 
S., McCowan, C., Montmayeur, A., Steelman, S., Frimodt-Moller, J., Petersen, A. M., Struve, C., Krogfelt, K. A., Bingen, E., Weill, F. X., Lander, E. S., Nusbaum, C., Birren, B. W., Hung, D. T. \& Hanage, W. P. (2012). Genomic epidemiology of the Escherichia coli O104:H4 outbreaks in Europe, 2011. Proceedings of the National Academy of Sciences of the United States of America, 109, 3065-3070.

Johnson, K. E., Thorpe, C. M. \& Sears, C. L. (2006). Emerging Infections: The Emerging Clinical Importance of Non- $\square$ O157 Shiga Toxin-Producing Escherichia coli. Clinical Infectious Diseases, 43, 1587-1595.

Kaper, J. B., Nataro, J. P. \& Mobley, H. L. T. (2004). Pathogenic Escherichia coli. Nature Reviews Microbiology, 2, 123-140.

Karmali, M. A., Gannon, V. \& Sargeant, J. M. (2010). Verocytotoxin-producing Escherichia coli (VTEC). Veterinary Microbiology, 140, 360-370.

LeJeune, J. T., Besser, T. E. \& Hancock, D. D. (2001). Cattle Water Troughs as Reservoirs

Lin, A., Sultan, O., Lau, H. K., Wong, E., Hartman, G. \& Lauzon, C. R. (2011). O serogroup specific real time PCR assays for the detection and identification of nine clinically relevant non-O157 STECs. Food Microbiology, 28, 478-483.

Liu, Y., DebRoy, C. \& Fratamico, P. (2007). Sequencing and analysis of the Escherichia coli serogroup O117, O126, and O146 O-antigen gene clusters and development of PCR assays targeting serogroup O117-, O126-, and O146-specific DNA sequences. Molecular and Cellular Probes, 21, 295-302.

Machado, J., Grimont, F. \& Grimont, P. A. D. (2000). Identification of Escherichia coli flagellar types by restrictionof the amplified fliC gene. Research in Microbiology, 151, $535-546$. 
Meng, J., LeJeune, J. T., Zhao, T. and Doyle, M. P. (2013). Enterohemorrhagic Escherichia coli. In: Doyle, M. P. and Buchanan, R. L. (Eds.), Food Microbiology: Fundamentals and Frontiers. ASM Press, Washington, D.C., pp. 287-309.

Monday, S. R., Beisaw, A. \& Feng, P. C. H. (2007). Identification of Shiga toxigenic Escherichia coli seropathotypes A and B by multiplex PCR. Molecular and Cellular Probes, 21, 308-311.

Muehlherr, J. E., Zweifel, C., Corti, S., Blanco, J. E. \& Stephan, R. (2003). Microbiological quality of raw goat's and ewe's bulk-tank milk in Switzerland. Journal of Dairy Science, 86, 3849-3856.

Nataro, J. P. \& Kaper, J. B. (1998). Diarrheagenic Escherichia coli. Clinical Microbiology Reviews, 11, 142-201.

Oswald, E., Schmidt, H., Morabito, S., Karch, H., Marches, O. \& Caprioli, A. (2000). Typing of intimin genes in human and animal enterohemorrhagic and enteropathogenic Escherichia coli: characterization of a new intimin variant. Infection and Immunity, 68, 64-71.

Paton, A. W. \& Paton, J. C. (1998a). Detection and characterization of shiga toxigenic Escherichia coli by using multiplex PCR assays for stx1, stx2, eaeA, enterohemorrhagic E. coli hlyA, rfbO111, and rfbO157. Journal of Clinical Microbiology, 36, 598-602.

Paton, J. C. \& Paton, A. W. (1998b). Pathogenesis and diagnosis of Shiga toxin-producing Escherichia coli infections. Clinical Microbiology Reviews, 11, 450-479.

Perelle, S., Dilasser, F., Grout, J. \& Fach, P. (2004). Detection by 5'-nuclease PCR of Shigatoxin producing Escherichia coli O26, O55, O91, O103, O111, O113, O145 and O157: H7, associated with the world's most frequent clinical cases. Molecular and Cellular Probes, 18, 185-192. 
Rey, J., Sánchez, S., Blanco, J. E., Hermoso de Mendoza, J., Hermoso de Mendoza, M., García, A., Gil, C., Tejero, N., Rubio, R. \& Alonso, J. M. (2006). Prevalence, serotypes and virulence genes of Shiga toxin-producing Escherichia coli isolated from ovine and caprine milk and other dairy products in Spain. International Journal of Food Microbiology, 107, 212-217.

Rey, J., Blanco, J. E., Blanco, M., Mora, A., Dahbi, G., Alonso, J. M., Hermoso, M., Hermoso, J., Alonso, M. P., Usera, M. A., González, E. A., Bernárdez, M. I. \& Blanco, J. (2003). Serotypes, phage types and virulence genes of Shiga-producing Escherichia coli isolated from sheep in Spain. Veterinary Microbiology, 94, 47-56.

Sails, A. D., Fox, A. J., Bolton, F. J., Wareing, D. R. \& Greenway, D. L. (2003). A real-time PCR assay for the detection of Campylobacter jejuni in foods after enrichment culture. Applied and Environmental Microbiology, 69, 1383-1390.

Scheutz, F., Møller Nielsen, E., Frimodt-Møller, J., Boisen, N., Morabito, S., Tozzoli, R., Nataro, J. \& Caprioli, A. (2011). Characteristics of the enteroaggregative Shiga toxin/verotoxin-producing Escherichia coli O104: H4 strain causing the outbreak of haemolytic uraemic syndrome in Germany, May to June 2011. Euro Surveillance, 16, 19889.

Scheutz, F., Teel, L. D., Beutin, L., Piérard, D., Buvens, G., Karch, H., Mellmann, A., Caprioli, A., Tozzoli, R., Morabito, S., Strockbine, N. A., Melton-Celsa, A. R., Sanchez, M., Persson, S. \& O'Brien, A. D. (2012). Multicenter Evaluation of a Sequence-Based Protocol for Subtyping Shiga Toxins and Standardizing Stx Nomenclature. Journal of Clinical Microbiology, 50, 2951-2963.

Vimont, A., Vernozy-Rozand, C. \& Delignette-Muller, M. -. (2006). Isolation of E. coli O157:H7 and non-O157 STEC in different matrices: review of the most commonly used enrichment protocols. Letters in Applied Microbiology, 42, 102-108. 
439 Wang, G., Clark, C. G. \& Rodgers, F. G. (2002). Detection in Escherichia coli of the genes 440 encoding the major virulence factors, the genes defining the O157:H7 serotype, and 441 components of the type 2 Shiga toxin family by multiplex PCR. Journal of Clinical 442 Microbiology, 40, 3613-3619.

443 Werber, D., Fruth, A., Buchholz, U., Prager, R., Kramer, M., Ammon, A. \& Tschäpe, H. 444 (2003). Strong association between Shiga toxin-producing Escherichia coli O157 and 445 virulence genes stx 2 and eae as possible explanation for predominance of serogroup $446 \quad 0157$ in patients with haemolytic uraemic syndrome. European Journal of Clinical 447 Microbiology and Infectious Diseases, 22, 726-730.

448 Willford, J., Mills, K. \& Goodridge, L. D. (2009). Evaluation of Three Commercially 449 Available Enzyme-Linked Immunosorbent Assay Kits for Detection of Shiga Toxin. $450 \quad$ Journal of Food Protection, 72, 741-747.

451 Zdragas, A., Samouris, G., Filiousis, G. \& Petridou, E. (2009). Isolation of Escherichia coli 452 O157: H7 from raw ewes’ and goats’ milk in Greece. Archiv Für Lebensmittelhygiene, 3, $453 \quad 36-38$. 
457 Primer sequences and predicted amplicon lengths of genes involved in the virulence of 458 Shiga toxin-producing Escherichia coli.

459

\begin{tabular}{|c|c|c|c|c|}
\hline Target & Primer & Primer sequence (5'-3’) & $\begin{array}{l}\text { Amplicon } \\
\text { size (bp) }\end{array}$ & Reference \\
\hline \multirow[t]{2}{*}{ stx1 } & Stx1F & ATAAATTGCCATTCGTTGACTAC & 180 & (Paton and \\
\hline & Stx1R & AGAACGCCCACTGAGATCATC & & Paton, \\
\hline \multirow[t]{2}{*}{ stx2 } & Stx2F & GGCACTGTCTGAAACTGCTCC & 255 & 1998a) \\
\hline & Stx2R & TCGCCAGTTATCTGACATTCTG & & \\
\hline \multirow[t]{2}{*}{ Eae } & SK1 & CCCGAATTCGGCACAAGCATAAGC & 881 & (Oswald, et \\
\hline & SK2 & CCCGGATCCGTCTCGCCAGTATTCG & & al., 2000) \\
\hline EHEC & HlyA- & AGCTGCAAGTGCGGGTCTG & 569 & (Wang, et \\
\hline \multirow[t]{3}{*}{ hlyA } & $\mathrm{a}$ & & & al., 2002) \\
\hline & HlyA- & TACGGGTTATGCCTGCAAGTTCAC & & \\
\hline & $\mathrm{b}$ & & & \\
\hline \multirow[t]{2}{*}{ eaer1 } & AE 19 & CAGGTCGTCGTGTCTGCTAAA & 1087 & (Gannon, et \\
\hline & AE 20 & TCAGCGTGGTTGGATCAACCT & & al., 1993) \\
\hline \multirow[t]{4}{*}{ stx1a } & stx1a- & CCTTTCCAGGTACAACAGCGGTT & 478 & (Scheutz, et \\
\hline & $\mathrm{F} 1$ & & & al., 2012) \\
\hline & stx1a- & GGAAACTCATCAGATGCCATTCTGG & & \\
\hline & $\mathrm{R} 2$ & & & \\
\hline \multirow[t]{3}{*}{ stx $1 c$} & stx1c- & CCTTTCCTGGTACAACTGCGGTT & 252 & \\
\hline & F1 & & & \\
\hline & stx1c- & CAAGTGTTGTACGAAATCCCCTCTGA & & \\
\hline
\end{tabular}


$\mathrm{R} 1$

stx1d stx1d- CAGTTAATGCGATTGCTAAGGAGTTTACC 203

F1

stx1d- $\quad$ CTCTTCCTCTGGTTCTAACCCCATGATA

$\mathrm{R} 1$

stx2a stx2a- GCGATACTGRGBACTGTGGCC 349

F2

347

stx2a- CCGKCAACCTTCACTGTAAATGTG

R3

stx2a- GGCCACCTTCACTGTGAATGTG

R2

$s t x 2 b \quad$ stx2b- AAATATGAAGAAGATATTTGTAGCGGC 251

F1

stx2b- CAGCAAATCCTGAACCTGACG

$\mathrm{R} 1$

stx2c stx2c- GAAAGTCACAGTTTTTATATACAACGGGTA 177

F1

stx2c- CCGGCCACYTTTACTGTGAATGTA

R2

stx2d stx2d- AAARTCACAGTCTTTATATACAACGGGTG 179

F1

280

stx2d- TTYCCGGCCACTTTTACTGTG

$\mathrm{R} 1$

stx2d- GCCTGATGCACAGGTACTGGAC

R2 
stx2e stx2e- CGGAGTATCGGGGAGAGGC

F1

stx2e- CTTCCTGACACCTTCACAGTAAAGGT

$\mathrm{R} 2$

stx2f stx2f- TGGGCGTCATTCACTGGTTG

F1

stx2f- TAATGGCCGCCCTGTCTCC

$\mathrm{R} 1$

stx2g stx2g- CACCGGGTAGTTATATTTCTGTGGATATC 573

F1

stx2g- GATGGCAATTCAGAATAACCGCT

$\mathrm{R} 1$

460

461

462

463 
465 Primers used in PCR for detection of serotypes of Escherichia coli.

466

\begin{tabular}{|c|c|c|c|c|c|}
\hline $\begin{array}{l}\text { Antig } \\
\text { en }\end{array}$ & $\begin{array}{l}\text { Targ } \\
\text { et } \\
\text { gene }\end{array}$ & $\begin{array}{l}\text { Primer } \\
\text { s }\end{array}$ & Sequence (5’-3’) & $\begin{array}{l}\text { Amplic } \\
\text { on size } \\
\text { (bp) }\end{array}$ & $\begin{array}{l}\text { Referen } \\
\text { ce }\end{array}$ \\
\hline H7 & $\begin{array}{l}\text { fliCh } \\
7\end{array}$ & $\begin{array}{l}\text { FLICH } \\
7-F \\
\text { FLICH } \\
7-\mathrm{R}\end{array}$ & $\begin{array}{l}\text { GCGCTGTCGAGTTCTATCGAGC } \\
\text { CAACGGTGACTTTATCGCCATTCC }\end{array}$ & 625 & $\begin{array}{l}\text { (Ganno } \\
\text { n, et al., } \\
\text { 1997) }\end{array}$ \\
\hline O26 & $w Z x$ & $\begin{array}{l}\text { 5'O26 } \\
\text { 3'O26 }\end{array}$ & $\begin{array}{l}\text { ACTCTTGCTTCGCCTGTT } \\
\text { CAGCGATACTTTGAACCTTAT }\end{array}$ & 268 & $\begin{array}{l}\text { (Monda } \\
\text { y, et al., } \\
\text { 2007) }\end{array}$ \\
\hline O45 & $w z y$ & $\begin{array}{l}\text { 5'O45 } \\
\text { 3'O45 }\end{array}$ & $\begin{array}{l}\text { TACGATTTCACAAGCTTCCA } \\
\text { TGCAATCGCATAAGGAAATA }\end{array}$ & 254 & $\begin{array}{l}\text { (Lin, et } \\
\text { al., } \\
\text { 2011) }\end{array}$ \\
\hline O91 & $w z y$ & $\begin{array}{l}\text { 5'O91 } \\
\text { 3'O91 }\end{array}$ & $\begin{array}{l}\text { CGATTTTCTGGAATGCTTGATG } \\
\text { CAATACATAGTTTGATTTGTGTTTAAA } \\
\text { GTTTAAT }\end{array}$ & 105 & $\begin{array}{l}\text { (Perelle, } \\
\text { et al., } \\
\text { 2004) }\end{array}$ \\
\hline O103 & $w z X$ & $\begin{array}{l}\text { 5'O103 } \\
\text { 3'O103 }\end{array}$ & $\begin{array}{l}\text { TATCCTTCATAGCCTGTTGTT } \\
\text { AATAGTAATAAGCCAGACACCTG }\end{array}$ & 320 & $\begin{array}{l}\text { (Monda } \\
\text { y, et al., } \\
\text { 2007) }\end{array}$ \\
\hline O104 & $w Z X$ & $\begin{array}{l}\text { 5'O104 } \\
\text { 3'O104 }\end{array}$ & $\begin{array}{l}\text { TGTCGCGCAAAGAATTTCAAC } \\
\text { AAAATCCTTTAAACTATACGCCC }\end{array}$ & 99 & $\begin{array}{l}\text { (Bugare } \\
\text { l, et al., } \\
\text { 2010) }\end{array}$ \\
\hline
\end{tabular}




\begin{tabular}{|c|c|c|c|c|c|}
\hline O111 & $w z X$ & 5'O111 & GTTGCGAGGAATAATTCTTCA & 829 & (Monda \\
\hline & & .3 & & & $y$, et al., \\
\hline & & 3'O111 & CCATAGATATTGCATAAAGGC & & 2007) \\
\hline & & ,2 & & & \\
\hline O121 & $w Z X$ & 5'O121 & GTAGCGAAAGGTTAGACTGG & 651 & (Monda \\
\hline & & 3'O121 & ATGGGAAAGCTGATACTGC & & $y$, et al., \\
\hline & & & & & 2007) \\
\hline O128 & $w z X$ & 5'O128 & TCGATCGTCTTGTTCAGGTT & 195 & (Lin, et \\
\hline & & 3'O128 & GAATGCAATGGGCAATTAAC & & al., \\
\hline & & & & & 2011) \\
\hline $\mathrm{O} 145$ & $w z X$ & 5'O145 & TTGAGCACTTATCACAAGAGATT & 418 & (Monda \\
\hline & & .6 & & & y, et al., \\
\hline & & 3'O145 & GATTGAATAGCTGAAGTCATACTAAC & & 2007) \\
\hline & & . B & & & \\
\hline O146 & $w z y$ & 5'O146 & ATTCGGGTAACGACCCTGTGTTGA & 378 & (Liu, et \\
\hline & & 3'O146 & AGACTGCTAATGCAAGGAACATGG & & al., \\
\hline & & & & & 2007) \\
\hline $\mathrm{H}$ & flic & FliC-F & CAAGTCATTAATAC(A/C)AACAGCC & Variabl & (Macha \\
\hline antige & & FliC-R & GACAT(A/G)TT(A/G)GA(G/A/C)ACTTC( & e & do, et \\
\hline $\mathrm{n}$ & & & $\mathrm{G} / \mathrm{C}) \mathrm{GT}$ & & al., \\
\hline & & & & & 2000) \\
\hline
\end{tabular}




\section{Table 3}

470 Prevalence of stx genes in milk and environmental samples.

471

\begin{tabular}{lllllll}
\hline Sample & Season & & stx1 & stx2 & stx1/stx2 & Total \\
\hline Milk & & 388 & $35(9.02 \%)$ & $39(10.05 \%)$ & $102(26.29 \%)$ & $176(45.36 \%)$ \\
Water & Spring & 10 & & $3(30 \%)$ & $1(10 \%)$ & $4(40 \%)$ \\
& Summer & 10 & $5(50 \%)$ & & $5(50 \%)$ \\
Faeces & Spring & 10 & & $2(20 \%)$ & & $2(20 \%)$ \\
& Summer & 10 & & $3(30 \%)$ & & $3(30)$ \\
Total & & 428 & $35(8.18 \%)$ & $52(12.15 \%)$ & $103(24.06 \%)$ & $190(44.39 \%)$
\end{tabular}

472

473

Table 4

474 Origin, stx genes and serotypes of STEC isolates.

475

\begin{tabular}{llllll}
\hline Source & Isolates (\%) & stx1a & stx1c & stx2c (O157:H7) & stx1c/stx2b \\
\hline Milk & $50(80.6)$ & 2 & 35 & 3 & $10(2$ O146:H21) \\
Faeces & $10(16.13)$ & & 9 & & 1 \\
Water & $2(3.22)$ & & 1 & 1 & \\
Total & 62 & 2 & 45 & 4 & 11 \\
\hline
\end{tabular}

476

477 